\title{
THEORETICAL AND PRACTICAL PROBLEMS OF THE LEGAL REGULATION OF SOCIAL RELATIONS
}

Collective monograph

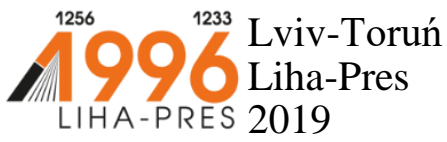




\section{Reviewers:}

Prof. dr hab. Sabina Grabowska, Uniwersytet Rzeszowski / University of Rzeszow (Republic of Poland);

Prof. dr hab. Joanna Marszalek-Kawa, Uniwersytet Mikotaja Kopernika w Toruniu / Nicolaus Copernicus University (Republic of Poland).

Theoretical and practical problems of the legal regulation of social relations : collective monograph / V. V. Abroskin, S. S. Andreichenko V. V. Bondar, G. V. Chebotareva, etc. - LvivTorun : Liha-Pres, 2019. - 320 p.

ISBN 978-966-397-177-3

Liha-Pres is an international publishing house which belongs to the category "C" according to the classification of Research School for Socio-Economic and Natural Sciences of the Environment (SENSE) [isn: 3943, 1705, 1704, 1703, 1702, 1701; prefixMetCode: 978966397]. Official website www.sense.nl. 


\section{CONTENTS}

PREVENTIVE ACTIVITY OF BODIES

OF THE NATIONAL POLICE OF UKRAINE

IN THE AREA OF THE UNITED FORCES OPERATIONS

Abroskin V. V.

PECULIARITIES OF ESTABLISHMENT

OF INTERNATIONAL RESPONSIBILITY OF THE STATE FOR THE BEHAVIOR OF EXECUTIVE AUTHORITIES

Andreichenko S. S 20

ORGANIZATIONAL AND LEGAL BASIS

OF COOPERATION OF UKRAINE AND THE EUROPEAN

UNION IN THE LAW ENFORCEMENT FIELD

ORGANIZATIONAL AND LEGAL BASIS OF COOPERATION

OF UKRAINE AND THE EUROPEAN UNION IN THE LAW

ENFORCEMENT FIELD

Bondar V. V.

FREEDOM OF CITIZENS IN THE CONDITIONS

OF MILITARY SERVICE

Chebotareva G. V.

THEORETICAL-LEGAL CHARACTERISTICS

OF LEGAL CONFLICT IN LEGAL RELATIONS

ON ADMINISTRATIVE SUPERVISION

Denysova A. V.

PLACES AND FUNCTIONS OF CIVIL PROCEDURAL LEGAL RELATIONS IN THE MECHANISM

OF CIVIL PROCESSING REGULATION

Didenko L. V.

REGULATION OF FREEDOM OF ACCESS TO

ENVIRONMENTAL INFORMATION IN THE LEGISLATION

OF THE EUROPEAN UNION AND UKRAINE

Kachuriner V. I 
CATEGORY OF "PROPERTY" AND SUBJECTS

OF PROPERTY RIGHTS PROTECTION

OF THE ECHR

Kizlova O. S.

COOPERATION OF STATES IN THE FIGHT

AGAINST CRIME

Klyuev O. M.

DOCTRINE OF LEGAL ORDER IN UKRAINIAN

AND FOREIGN JURISPRUDENCE: STATUS

AND PROSPECTS OF CONVERGENCE LEGAL ORDER

AS AN EMPIRICAL STATE OF LEGAL LIFE IN SOCIETY

(OR WHATSOEVER)

Kryzhanovskii A. F.

METHODOLOGICAL BASIS OF THE RESEARCH

OF LEGAL ALGORITHMS

Manko D. G.

ADMINISTRATIVE RESPONSIBILITY

IN THE CONSTRUCTION INDUSTRY

Nenko S. S. 208

ACTUAL PROBLEMS OF COVERT INVESTIGATION

Podobnyi O. 0.

THE GENESIS OF ADMINISTRATIVE OFFENCES

Popovich Ye. M. 246

DOCUMENTATION OF ADMINISTRATIVE

ACTIVITIES BY THE POLICE OF UKRAINE

Predmestnikov O. G. 261

INNOVATION POLICY AND PATENT STRATEGIES

OF PHARMACEUTICAL COMPANIES ECONOMIC AND SOCIAL ASPECTS

Rachinska I. M. 278

APPEAL PROCEEDINGS

Voronin Ya. G. 297 


\title{
PREVENTIVE ACTIVITY OF BODIES OF THE NATIONAL POLICE OF UKRAINE IN THE AREA OF THE UNITED FORCES OPERATIONS
}

\begin{abstract}
Abroskin V. V.
INTRODUCTION

The Constitution of Ukraine defines the protection of the state sovereignty of Ukraine, territorial integrity, inviolability of the state border as one of the most important functions of the state at the present stage ${ }^{1}$.

In 2014, the Russian Federation launched an armed aggression against Ukraine, which resulted in the illegal occupation of the Autonomous Republic of Crimea $^{2}$, carrying out armed invasion into the territory of Donetsk and Luhansk regions ${ }^{3}$. Armed conflicts become more intense, so the united forces operations in Donetsk and Luhansk regions influenced the need to study approaches to resolving armed conflict within the state.

The security vector is identified as one of the key vectors of the development of our country, in accordance with the Strategy of Sustainable Development "Ukraine-2020", that should provide ensuring the security of the state, business and citizens ${ }^{4}$. Our state is tasked with becoming a state capable of protecting its borders and ensuring public security not only in its territory but also in the European region. In turn, this task requires adjusting the tasks and functions of the police, introducing new criteria for evaluating police performance.

Today, the National Police of Ukraine is a universal system of structural units, which are entrusted with important functions to ensure law and order in the state, protection of the population. In the territory of modern Ukraine there is a new, reformed system of bodies of the National Police of Ukraine, which actively borrows the best international practices in order to optimize its own
\end{abstract}

1 Василенко В. А. Російсько-українська війна 2014 року: причини, перебіг та політико-правові оцінки. Украӥнський тиждень. 2014. № 42. С. 28-42.

2 Про Стратегію сталого розвитку “Україна - 2020": Указ Президента України від 12 січ. 2015 p. № 5/2015. URL: http://zakon2.rada.gov.ua/laws/show/5/2015 (дата звернення 15.10.2019).

3 Про Стратегію сталого розвитку “Україна - 2020": Указ Президента України від 12 січ. 2015 р. № 5/2015. URL: http://zakon2.rada.gov.ua/laws/show/5/2015 (дата звернення 15.10.2019).

4 Про Стратегію сталого розвитку “Україна-2020": Указ Президента України від 12 січ. 2015 p. № 5/2015. URL: http://zakon2.rada.gov.ua/laws/show/5/2015 (дата звернення 15.10.2019). 
activities. One of the such practice is to change the work vector of these bodies by transforming them from punitive to preventive, and in some cases - to service agencies. This is due primarily to the fact that the main value for many states is directly human today, since the suppression of rigid coercive measures is gradually being replaced by the development and implementation of preventive measuresThe implementation of these measures by the police is, first of all, an important guarantee of respect for human rights and freedoms; secondly, it increases the level of legal consciousness in society; thirdly, it significantly increases the level of public trust in law enforcement, which has a positive impact on the state of law and order in the country. Необхідність здійснення превентивних заходів The need for preventive measures by the police is confirmed by the number of detected administrative offenses, in particular - in 2016 - 1 million 656 thousand, 2017 - 2 million 845 thousand, $2018-3$ million 639 thousand 5 .

The activities of the police directed at reducing the number of criminal, administrative and other offenses, and it is not enough to stop unlawful acts, every effort should be made to prevent them from committing at all.

The theoretical basis of the study are works of Ukrainian scientists on the study of certain aspects of law enforcement and, in particular, the legal regulation of the activities of police in the field of public security, namely: V. Averyanova, S. Alfiorova, O. Andriyko, O. Bandurki, O. Bezpalova, Y. Bityaka, V. Galunko, V. Garashchuk, O. Hetmanets, I. Golosnichenko, N. Grishina, S. Gusarova, O. Jafarova, O. Klyueva, T. Kolomoets, V. Kolpakova, A. Komzyuka, O. Kuzmenko, K. Levchenko, O. Nikolenko, O. Muzychuk, O. Sinyavskaya, V. Sokurenko, S. Stetsenko and others.

An in-depth study of the preventive activity of the police in armed conflicts within the state not only makes it possible to improve the efficiency and effectiveness of administrative activity in the context of emergency administrative and legal regimes, but also allows to determine the optimal measures for their settlement. At present, the issue of preventive activity by the police during the united forces operation remains an issue in view of the lack of research of scientific developments in this field.

\section{Methodological approaches \\ about understanding preventive police activity}

The Constitution of Ukraine declared that a person, his life and health, honor and dignity, integrity and security are recognized in Ukraine as the

5 Адміністративні правопорушення: демографічна та соціальна статистика. Правосуддя та злочинність. Державна служба статистика Украйни: веб-сайт. URL: http://www.ukrstat.gov.ua (дата звернення: 15.10.2019). 
highest social value ${ }^{6}$. For the purpose of practical implementation of the above constitutional requirements, the relevant law enforcement agencies are functioning in our country, among which are the bodies of the National Police of Ukraine. They are the ones responsible for fulfilling the task of carrying out preventive activities.

According to paragraphs 1, 2 and 3 of Part 1 of Art. 23 ("Basic powers of the police") of the Law of Ukraine "About the National Police" the police in accordance with the tasks assigned to it: "carry out preventive activities aimed at preventing the commission of offenses; identifies the causes and conditions conducive to the commission of criminal and administrative offenses, and takes measures within their competence to eliminate them; takes measures to detect criminal and administrative offenses, as well as suspends detected criminal and administrative offenses"

Preventive police activity is aimed at preventing offenses that could potentially be committed by a person or a group of people, and is a complex of legal, organizational and psychological measures that together allow to prevent committing offenses.

For a full research, first of all, should refer to the definition of "preventive", that means "that prevents something". In turn, preventive police activity is a complex of actions (measures) implemented by police officers for the purpose of preventing an offense. This is to some extent reflected in the doctrinal definitions of the concept of "preventive police activity", about which there is no unambiguous understanding, and there is no definition of the object of its purpose - offense, misdemeanor or crime.

For example, I. Volokitenko proposes the author's definition of the concept of "preventive activity" as "a special type of activity of police officers who in their work prevent committing offenses in the public order"9. This concept is explained in details by R. Valeev and D. Churikov, understanding it as "a component of combating crime, and identifying special prevention aimed at preventing crimes by specific people, and general prevention aimed at preventing crime by an indeterminate number of

${ }^{6}$ Конституція України : Закон України від 28 черв. 1996 р. № 254к/96-BP. URL: http://zakon.rada.gov.ua/laws/show/254к/96-BР (дата звернення: 03.10.2019).

${ }^{7}$ Про Національну поліцію : Закон України від 02 липн. 2015 р. № 580-VIII. URL: https://zakon.rada.gov.ua/laws/show/580-19 (дата звернення: 15.10.2019).

${ }^{8}$ Словник української мови : в 11 т./ голова редкол. І. К. Білодід. Київ : Наукова думка, 1976. Т. 7.724 с.

9 Волокітенко I. О. Адміністративно-правовий статус підрозділів превентивної діяльності Національної поліції України. Visegrad Journalon Human Rights. 2016. № 6. Ч. 2. C. 42-46. 
people. At the same time, the objects of prevention, in addition to people, are criminogenic determinants of crime" 10 .

The content of preventive activity can be submitted from the understanding of measures by which it is implemented. N. Didik notes that "in law preventive measures are called preventive and other measures aimed at preventing criminal offenses and other offenses. In legal science, distinguish such types of prevention as general prevention - preventing the commission of offenses by other people. It is the prevention of committing criminal offenses by citizens prone to wrongdoing; private prevention means the prevention of committing new criminal offenses by people who have already committed any offenses"11.

The ambiguity of understanding of the correlation of the above concepts is noticed by $\mathrm{O}$. Batrachenko, who defines forms of preventive activity of the National Police: "identify the causes and conditions that contribute to the commission of administrative offenses that encroaching on public safety and the procedure for taking measures within their competence to eliminate them; monitoring the causes and conditions that contributed to the commission of administrative offenses that violate public safety and order; determination of the state of public security and order in the state or in a specific territory; developing measures to maintain and enhance public safety and order; monitoring of the operational situation in the country; study, analysis and generalization of results and effectiveness of police activity; informing in the manner and manner prescribed by law the relevant state bodies; round-the-clock patrolling of the service area to ensure proper public order, public safety and traffic enforcement; taking measures aimed at eliminating threats to the life and health of individuals and public safety resulting from the commission of an administrative offense that violates public safety and order; taking measures to prevent and end domestic violence; demands from citizens to observe public order and from persons who violate public order, termination of offenses" ${ }^{\prime 2}$.

In this manner, it can be concluded that the concepts of preventive and preventive activities are not differentiated in the scientific community.

${ }^{10}$ Валєєв Р. Г., Чуріков Д. С. Превентивна діяльність поліцейських як стадія протидії злочинності. Актуальні питання протидї злочинності в сучасних умовах: вітчизняний та зарубіжний досвід : матеріали II Міжнар. наук.-практ. конф., 15 бер. 2013 р. Дніпро : Дніпропетр. держ. ун-т внутр. справ, 2018. С. 212-215.

${ }^{11}$ Дідик Н. І. Превентивні функції в діяльності патрульної поліції. Вісник Луганського державного університету внутрімніх справ імені Е. О. Дідоренка. 2016. Вип. 2. C. $188-194$.

${ }^{12}$ Батраченко О. В. Форми правоохоронної діяльності національної поліції щодо забезпечення публічної безпеки та порядку в державі. Форум права. 2016. № 2. С. 5-10. URL: http://nbuv.gov.ua/j-pdf/FP_index.htm_2016_2_3. (дата звернення: 15.10.2019). 
However, the legislator, in Art. 23 of the Law of Ukraine "On the National Police" specifies that the police carry out preventive activities aimed at preventing offenses and set out in Art. 31 preventive police measures, which include: 1) verification of identity documents; 2) interviewing a person; 3) surface inspection and inspection; 4) stopping the vehicle; 5) the requirement to leave space and restrict access to the designated area; 6) restriction of movement of the person, vehicle or actual possession of the thing; 7) penetration into the dwelling or other possession of a person; 8 ) verification of compliance with the requirements of the permit system of law enforcement agencies; 9) the use of technical instruments and equipment having the functions of photo and film, video recording, photo and film means, video; 10) verification of compliance with the statutory restrictions on persons under administrative supervision and other categories of persons; 11) police care ${ }^{13}$.

Because of the plurality of terms, that used by the legislator, the content and relation of concepts remain unclear: "prevention", "termination" remain unclear. The concept of "prevention" in the disclosure of its essence is almost identical with the activity aimed at preventing offenses, but prevention is aimed at it. It is most often used in the context of prevention of offenses - "a complex multilevel system of bodies, organizations, institutions that influence social objects in order to prevent possible violations of legal prohibitions and eliminate the factors that cause them"14.

If "prevention" can be used as common in their meaning, termination of the offense will occur in case of unlawful intent in the person directly during its commission. Prevention has a more specific effect on the subject of "preventing something unpleasant, unwanted"15, a Prevention has a more specific impact because it implies "preventing or preventing something unpleasant, unwanted", so it can take place both as a preventative, preventive measure (more generally, to carry out general preventive measures aimed at preventing certain categories of offenses) and during the termination of the offense. In this manner, Prevention of the offense is most often carried out at the stages of detecting the intention or preparation for the offense, and less often during the prevention of its commission. The termination of the offense can only take place if the unlawful activity has already begun.

${ }^{13}$ Про Національну поліцію : Закон України від 02 липн. 2015 р. № 580-VIII. URL: https://zakon.rada.gov.ua/laws/show/580-19 (дата звернення: 15.10.2019).

${ }_{14}$ Макаренко О. М. Суб’єкти профілактики правопорушень. Право і Безпека. 2004. № 3 (3). С. $68-70$.

${ }^{15}$ Словник української мови : в 11 т. / голова редкол. І. К. Білодід. Київ : Наукова думка, 1976. Т. 7.724 с. 
In this case, the main task is to minimize or prevent the adverse effects of the offense. Prevention is carried out regardless of any particular offense, and is aimed at improving the criminogenic situation in the state and its individual regions.

Considering that the preventive activities carried out by the National Police may include the prevention of offenses, we consider it necessary to briefly outline the content of the latter ${ }^{16}$.

According to academician O. Bandurko prevention of offenses can be regarded as: 1) a system of collective and individual educational influences on the production of non-vulnerability, the formation of immunity to negative environmental influences in order to prevent the development of the personality orientation of the individual and realign the attitude of the individual to the reality in the process of re-education; 2) socially oriented organizational and legal activity of the state, its bodies and their officials, public organizations and individuals to identify the causes and conditions of committing crimes and offenses, eliminate the factors that contribute to the formation of antisocial behavior of a person, the elimination of offenses as a social phenomenon and restoration in the course of such activity of the rights and freedoms of Ukrainian citizens ${ }^{17}$.

That is, preventive activity is represented by a complex system with plurality of subjects of its implementation, which activities are united by a common purpose, but carried out by different methods that on different sides affect the reduction and destruction of factors that contribute to the origin of legal nihilism, the formation of antisocial behavior and lead to offenses, as well as common factors that contribute to the rise in crime (for example, mass unemployment; reduction of citizens' incomes; education; disadvantaged families; uncontrolled migration processes, etc.).

Particular importance for our study are scientific achievements of $\mathrm{V}$. Felika, obtained as a result of the investigation of the features of the prevention of offenses as one of the activities of the police, where the activity is proposed to be understood as "a system of police measures and powers, methods of their implementation, which are carried out with the purpose of preventing the commission of offenses or preventing or reducing their negative consequences., reducing the level of offenses in the state and in individual regions, ensuring a high level of public safety and order"18,

16 Клюєв О. М. Сутність та місце профілактичних заходів у правоохоронній діяльності. Право і суспільство. 2013. № 6. С. 195-197.

17 Бандурка О. М. Профілактика злочинності. Вісник Південного регіонального центру Начіональної академії правових наук України. 2014. № 1. С. 115-124.

18 Фелик В. І. Класифікація видів профілактичної діяльності Національної поліції України. Форум права. 2016. № 4. С. 313-316. URL: http://nbuv.gov.ua/jpdf/FP_index.htm_2016_4_51 (дата звернення: 15.10.2019). 
based on the following principles: priority of life, health, rights, freedoms and interests, honor and dignity of the individual and the citizen; democracy; personal freedom and privacy; equality of all citizens; the exclusivity and proportionality of the use of force by the police when taking preventive measures; honesty, impartiality and dignity; personal responsibility for the consequences of actions; legality; openness and transparency; political neutrality; partnerships with the public; continuity ${ }^{19}$.

That is, the prevention of offenses is a large-scale activity of subjects, where the police make a separate impact on the factors and conditions that lead to the commission of offenses, within the powers stipulated by the current legislation.

There is also no unanimous approach to the classification of prevention of offenses, and on the other hand, certain types of classifications are partially repeated by others. O. Dzhuzha and Y. Kondratyev distinguishes the following types of prevention: general, individual and early prevention of crimes - early detection and elimination of circumstances that in the future will affect the formation of deviant behavior of a person or group of people $^{20}$. In turn, academician O. Bandurka, focuses on emphasizes the expediency of classifying the prevention of offenses into general social and special, specifying that the latter consists of: "general special prevention; prevention of certain groups (types) of offenses; individual prevention; prevention of offenses" ${ }^{\prime 2}$.

More common in jurisprudence is the approach that identifies three types of prevention: general, special and individual ${ }^{22,23}$. More common in jurisprudence is the approach that distinguishes three types of prevention: general, special, and individual. Moreover, the contents of these species fully or partially coincide with the other types of prevention defined by us above (meaning general, special criminological and individual prevention).

Summarizing the above, we can state that the essence and content of preventive activity, as well as preventive activity, is a debatable question, the uncertainty of which determines the multiplicity of doctrinal views on its

19 Фелик В. І. Профілактика правопорушень як особливий напрям діяльності Національної поліції України. Прикарпатський юридичний вісник. 2015. Вип. 3. C. 229-232.

${ }^{20}$ Кримінологія : підручник / Джужа О. М. та ін.; за заг. ред. О. М. Джужи. Київ : Юрінком Інтер, 2002. 416 c.

21 Бандурка О. М. Профілактика злочинності. Вісник Південного регіонального центру Національної академії правових наук України. 2014. № 1. С. 115-124.

${ }_{22}^{22}$ Клюєв О. М. Сутність та місце профілактичних заходів у правоохоронній діяльності. Право і суспільство. 2013. № 6. С. 195-197.

23 Фелик В. І. Класифікація видів профілактичної діяльності Національної поліції України. Форум права. 2016. № 4. С. 313-316. URL: http://nbuv.gov.ua/j-pdf/FP_ index.htm_2016_4_51 (дата звернення: 15.10.2019). 
content, means and forms and requires specification, foremost in national law, and the adoption of a relevant legislative document that would not only identify important concepts for understanding prevention activities, and established a system of subjects and relationships between them during various preventive measures. In addition, the ambiguity of understanding of preventive activities complicates the understanding of another concept "preventive activity", during which preventive measures may take place. In this regard, the drafting and adoption of the Law of Ukraine "On Preventive Activities" is relevant.

However, it should be noted that, despite some doctrinal gaps, preventative activities have positive results, for example: optimization and increase of patrol routes in settlements in the area of the united forces operations; providing outreach, including the use of printing products and online resources; effective interaction with banking institutions led to a decrease in crimes such as robberies $(-28.6 \%)$, robberies $(-23 \%)$, unlawful seizure of vehicles $(-62 \%)$, fraud $(-21 \%)^{24}$.

In view of the above, we can identify following signs of preventive activity of the National Police: a) this is a set of measures, techniques and methods provided for by national law; b) carried out by police officers within the limits of their powers; c) is an independent line of police activity, at the same time becoming one of the activities within the system of preventive measures carried out by different state bodies; d) aimed at preventing an offense; e) has short and long term character; f) can have a mass and individual orientation; g) is being implemented within the limits specified by law; h) includes preventive police measures and, as a rule, preventive measures.

In view of this, we propose to define the concept of "preventive activity of the National Police" in a broad and narrow sense, depending on need to include in its component preventive measures in each case. Preventive activity of the police in the broadest sense implies the implementation of a system of actions and preventive measures, as well as techniques, methods and methods, carried out by authorized representatives of the National Police of Ukraine, with the aim of preventing, rarely - preventing, offenses that may be committed by people.

A narrow understanding of the preventive activity of the bodies of the National Police tends to legislatively determine its individual aspects of

\footnotetext{
${ }^{24}$ Колесник С. П. Проблемні питання забезпечення правопорядку в зоні проведення операції Об'єднаних сил. Забезпечення правопорядку на території проведення операиії Об'єднаних сил : матеріали Всеукр. наук.-практ. семінару, 12 жовт. 2018 р. Маріуполь : МДУ, 2018. С. 85-94.
} 
implementation it is a set of preventive police measures envisaged by legal acts that regulating the activities of police bodies, including administrative and criminal legislation, which are carried out by police officers within the limits of the powers conferred on them by law in order to prevent and prevent administrative offenses and crimes.

The application of specific methods, means, as well as directly police preventive measures depends on a number of conditions, which include: the geographical location of the territory, as well as the political and social situation within it; operational and criminogenic situation; crime rate; the number of police personnel, their level of professionalism, ability and skills; time allotted for this or that preventive process; the specific purpose for which they are pursued; categories of population living in the territory, etc. All these factors determine the specificity of the preventive activity of the police in each case. The first factor should be attributed to the special conditions for preventive action in the context of the anti-terrorist operation: it influences the definition of other conditions mentioned above and, in the aggregate, determines the specificity of the implementation of preventive activities.

\section{Implementation of preventive activities by the National police in the area of the united forces operations}

The protection of public order and security in the territory of conducting an anti-terrorist operation in the east of Ukraine from April 14, 2014 to April 30, 2018 was carried out in the specific areas of activity, which, due to the lack of necessity, are not implemented by police bodies of other areas:

- ensuring law and order during the rallies in 2014. Seizure of administrative buildings of the regional prosecutor's office, SSU, in Donetsk, the city council in Mariupol;

- carrying out according to military orders for the development of settlements of Donetsk region, including settlements located on the demarcation line;

- provision of public order after the shelling in the settlements of the Eastern neighborhood in Mariupol, Avdiivka, Marinka, Krasnogorovka, Granitne, Sartani, Hnutove, Mironovskii and others;

- provision of filtering measures at roadblocks;

- protection of public order during the blocking of railway tracks and highways;

- protection of objects of life and infrastructure of cities;

- protection of public order during large-scale events such as the concert "Ocean Elsa" in 2015, the Mariupol Fest in 2017 and 2018; 
- ensuring the protection of public order by the MMNP personnel, erected detachments in the settlements located on the demarcation line Svitlodarsk, Ocheretyne, Sopine, Hnutovo, Sartana, Mariinka, Krasnogorovka, Avdiivka;

- conducting general garrison briefings on the territory of Donetsk region, implementation of armor groups ${ }^{25}$.

In particular, the transformation of the socio-political situation and the need to recognize the armed aggression of the Russian Federation against Ukraine necessitated a change in the legal regime on the territory of Luhansk and Donetsk regions. As a consequence, based on the Declaration of State Sovereignty of Ukraine and the Constitution of Ukraine, underlining that Ukraine's sovereignty extends over its entire territory, which is holistic and inviolable within the internationally recognized state border, remaining committed to the course of political and diplomatic settlement of conflicts and principles of conflict of international law and the Charter of the United Nations, 18.01.2018 The Verkhovna Rada of Ukraine adopted the Law of Ukraine "On Features of State Policy for Ensuring State Sovereignty in Ukraine in the temporarily occupied territories in Donetsk and Luhansk regions" ${ }^{26}$. The aforementioned regulatory act envisages the peculiarities of the state policy of securing the state sovereignty of Ukraine in the temporarily occupied territories in Donetsk and Luhansk regions.

The result of the legislative innovations was the signing on 30.04.2018 of the Presidential Decree "On approving the decision of the National Security and Defense Council of Ukraine" On a large-scale anti-terrorist operation in the Donetsk and Luhansk regions", which enters into force the decision of the National Security and Defense Council on changing the format of a large-scale anti-terrorist operation the operation, which was launched in $2014^{27}$. The Head of State also signed an order of the Supreme Commanderin-Chief of the Armed Forces of Ukraine "On the commencement of the operation of the Joint Forces for the provision of national security and

25 Горустович Ю.В. Основні оперативно-профілактичні заходи, спрямовані на забезпечення правопорядку у донецькому регіоні в умовах ООС. Забезпечення правопорядку на території проведення операції Об'єднаних сил: матеріали Всеукр. наук.-практ. семінару, 12 жовт. 2018 р. Маріуполь : МДУ, 2018. С. 95-106.

${ }^{26}$ Про особливості державної політики із забезпечення державного суверенітету України на тимчасово окупованих територіях у Донецькій та Луганській областях : Закон України від 18 січн. 2018 р. № 2268-VIII. URL: https://zakon.rada.gov.ua/laws/main/2268-19 (дата звернення: 01.10.2018).

27 Про затвердження рішення Ради національної безпеки і оборони України від 30 квітня 2018 року "Про широкомасштабну антитерористичну операцію в Донецькій та Луганській областях": Указ Президента України від 30 квіт. 2018 p. URL: https://zakon.rada.gov.ua/laws/show/116/2018 (дата звернення: 15.10.2019). 
defense, repulsion and deterrence of the armed aggression of the Russian Federation in the territory of Donetsk and Luhansk regions", according to which, from 14:00 April 30, 2018, the Joint Forces of the National Security and Defense Forces, Repulsion and Suppression of the Armed Forces of the Russian Federation in Donetsk and Lugansk Oblast will be launched, in accordance with the plan of the said operation.

According to Art. 8 of the Law of Ukraine "On the Features of State Policy for Ensuring State Sovereignty of Ukraine in temporarily occupied territories in Donetsk and Luhansk Regions" 28 . The National Police are referred to the subjects of national security and defense, repelling and deterring armed aggression of the Russian Federation in Donetsk and Luhansk regions.

In turn, among law enforcement agencies, the police play a leading role in ensuring law enforcement in the area of the said operation. Such a conclusion directly follows, in particular, from the definition and tasks assigned to the police.

Thus, according to Art. 1 of the Law of Ukraine "On the National Police" The National Police of Ukraine is the central executive body which serves the society by ensuring the protection of human rights and freedoms, combating crime, maintaining public safety and order. In turn, in Art. 2 of the above legal act defines the tasks of the National Police as providing police services in the areas of: 1) ensuring public safety and order; 2) protection of human rights and freedoms, as well as the interests of society and the state; 3) combating crime; 4) providing services, within the limits specified by law, to persons who, for personal, economic, social or emergency situations, require such assistance ${ }^{29}$. We think that the formulation of police tasks as "providing police services" has become the basis of police activity, which is to serve the community.

Therefore, in our opinion, the role of the National Police as a subject of public security in the context of an anti-terrorist operation can be characterized on two levels. At the first (general) level, the role of the National Police in providing security for the joint operation, as well as for other security and defense sector bodies, is to ensure national security and defense, to repel and deter armed aggression in Donetsk and Luhansk regions.

28 Про особливості державної політики із забезпечення державного суверенітету України на тимчасово окупованих територіях у Донецькій та Луганській областях : Закон України від 18 січн. 2018 р. № 2268-VIII. URL: https://zakon.rada.gov.ua/laws/main/2268-19 (дата звернення: 01.10.2018).

${ }^{29}$ Про Національну поліцію : Закон України від 02 липн. 2015 р. № 580-VIII. URL: https://zakon.rada.gov.ua/laws/show/580-19 (дата звернення: 15.10.2019). 
In turn, the second level is manifested in the implementation of specific tasks that are assigned to the police as a new law enforcement agency in accordance with provisions of the Law of Ukraine "On National Police", the adoption of which was necessitated by the need to reform the police. In this context, police activities become special importance to preserve the life and health that not involved in national security and defense activities, and export to or from the area of operation of weapons, ammunition, explosives and narcotic substances, etc. ${ }^{30}$

In accordance with the provision of the Law of Ukraine "On Features of State Policy for Ensuring State Sovereignty of Ukraine in Temporarily Occupied Territories in Donetsk and Luhansk Oblasts", preventive measures in the conditions of the operation of the combined forces are carried out by the police on a wider spectrum than in other regions of Ukraine.

The General Staff of the Armed Forces of Ukraine, in agreement with the respective leaders, shall involve and use forces and means (personnel and specialists of individual units, military units, weapons, military equipment, special and transport vehicles, telecommunication and telecommunication facilities, other material and technical means) of The Armed Forces of Ukraine, other military units formed according to laws of Ukraine (the Security Service of Ukraine, the State Service for Special Communication and Information Protection of Ukraine, the National Guard of Ukraine, the State Border Service of Ukraine, the Office of the State Protection of Ukraine, the State Special Transport Service), law enforcement agencies of the special purpose, the Ministry of Internal Affairs of Ukraine, the National Police of Ukraine, the intelligence agencies of Ukraine, the military prosecutor's office, the central executive authority implementing the state policy in the sphere of civil protection, as well as employees of healthcare institutions (paragraph 1 of Part 1 of Article 8) ) $^{31}$.

At the same time, according to the norms of item 2 of part 1 of Art. 8 of the said legislative act, employees of the National Police are given special powers in implementing measures for the protection of public security, including preventive activities, which are inherently broader than those which provided in Section V of the Law of Ukraine "On the National

30 Аброськін В. В. Роль органів Національної поліції щодо забезпечення правопорядку в зоні проведення операції Об'єднаних сил. Забезпечення правопорядку на території проведення операції Об 'єднаних сил : матеріали Всеукр. наук.-практ. семінару, 12 жовт. 2018 р. Маріуполь : МДУ, 2018. С. 23-50.

31 Про особливості державної політики із забезпечення державного суверенітету України на тимчасово окупованих територіях у Донецькій та Луганській областях : Закон України від 18 січн. 2018 р. № 2268-VIII. URL: https://zakon.rada.gov.ua/laws/main/2268-19 (дата звернення: 01.10.2018). 
Police". The procedure and conditions for their application are defined in Art. 12 of the Law of Ukraine "On the Features of State Policy for Ensuring State Sovereignty of Ukraine in Temporarily Occupied Territories in Donetsk and Luhansk Regions".

In particular, police officers may not be guided by the grounds specified in the relevant articles of the Law of Ukraine "On the National Police" during the following preventive measures: verification of identification documents (and, in their absence, detention for the purpose of identification); personal inspection of persons and their belongings, including vehicles; restricting or prohibiting the movement of any vehicles and persons at all; restricting access to certain areas and objects (removal of citizens from that territory or object, towage of vehicles); entry or penetration into the territories, land plots and premises of residential and non-residential types belonging to natural and legal people under private ownership $^{32}$.

The above measures can be defined as preventive, which in a special order are authorized to apply police in the security zones adjacent to the territory of the fighting. Also, the police of that areas, where held the united forces operation, do preventive measures to identify and stop the activities of illegal armed groups and sabotage groups, prevent the supply of weapons, ammunition and narcotics, counteract terrorist acts and sabotage, facts of extremism, preventing the commission of serious crimes, the rights and freedoms of citizens. Thus, a number of preventative measures are directly aimed at preventing terrorism.

This indicates that the area of the united forces operations assumes the presence of a separate territory. For example, according to the experience of Ukraine we are talking about the territory of Donetsk and Luhansk regions, where, according to Part 2 of Art. 5 of the Law of Ukraine "On Combating Terrorism", the Ministry of Internal Affairs of Ukraine together with the National Police organizes the fight against terrorism by preventing, detecting and stopping crimes committed for terrorist purposes, the investigation of which is covered by the legislation of Ukraine within the competence of the National Police; provides the Anti-Terrorist Center with the Security Service of Ukraine with the necessary resources and resources; ensures their effective use in counter-terrorism operations ${ }^{33}$.

32 Про Національну поліцію : Закон України від 02 липн. 2015 р. № 580-VIII. URL: https://zakon.rada.gov.ua/laws/show/580-19 (дата звернення: 15.10.2019).

${ }^{33}$ Про боротьбу з тероризмом : Закон України від 20 бер. 2003 р. № 638-15. URL: https://zakon.rada.gov.ua/laws/show/638-15 (дата звернення: 15.10.2019). 
In accordance with the Law of Ukraine "On the Fight against Terrorism" special and special purpose units were given the right to prevent the detention of people who involved in terrorist activities for more than 72 hours (the maximum period of preventive detention may not exceed 30 days).

The reason for the preventive detention is the existence of reasonable suspicion of committing a terrorist activity. Preventive detention is carried out by a reasoned decision of the Chief of the Main Directorate of the Security Service of Ukraine or the Chief of the Main Directorate of the Ministry of Internal Affairs of Ukraine in the Autonomous Republic of Crimea, in the respective area, in Kyiv and Sevastopol with the consent of the prosecutor and without the decision of the investigating judge, court. A copy of the decision on the preventive detention of a person who involved in terrorist activity shall be promptly forwarded to the detained person for a period of more than 72 hours and shall be immediately forwarded to the investigating judge, the court of the respective jurisdiction, together with the request for the election of the appropriate preventive measure against the person.

Preventive detention of a person may not continue after consideration by an investigating judge, a court requesting the election of an appropriate preventive measure against that person.

It should also be added that the Law "On the Fight against Terrorism" provides for the introduction of a special regime in the area of the united forces operations, according to which the subjects of the fight against terrorism have the special powers required by law for the release of hostages, security and health. citizens who were in the area of the operation of the United Forces, normal functioning of state bodies, local self-government bodies, enterprises, institutions, organizations.

The current legislation, namely item 7 of the Regulation on a unified state system of prevention, response and termination of terrorist acts and minimization of their consequences, established levels of terrorist threats:

"GRAY (possible threat)" - in the presence of factors contributing to the commission of a terrorist act;

"BLUE (potential threat)" - in the presence of information requiring confirmation about the preparation for the commission of a terrorist act;

"YELLOW (probable threat)" - in the presence of reliable and confirmed information about the preparation for committing a terrorist act;

"RED (real threat)" - in the case of a terrorist act.

Along with these levels, special security regimes have been established to determine the conditions of stay of citizens and the special powers of the National Police in the area of the united forces operations. Generally, it is 
possible to establish three modes: green, which does not restrict the stay of persons in a certain area; yellow, which is set for restricted areas; red, which is for restricted areas (facilities), the same mode is set in combat areas.

The level of specific powers of the National Police officers and the list of specific preventive measures that they can apply in the context of a joint operation depend on the establishment of a particular level. Thus, the general list of preventive measures defined in Art. 12 of the Law of Ukraine "On features of state policy on securing state sovereignty of Ukraine in temporarily occupied territories in Donetsk and Luhansk regions" 34 , it is not permanent, and it is subject to differentiation depending on the identified threat level.

It should also be emphasized that such preventive measures which are authorized by the police and their general list, which is defined in the legislation, are not exhaustive and may be changed by the Chief of General Staff - Commander-in-Chief of the Armed Forces of Ukraine upon submission by the Joint Force Commander in case of special order conditions, in particular:

1) threats of using lesions, including rocket troops and artillery, rocket launcher systems and aviation;

2) threats of terrorism and sabotage acts, which means, "committing for the purpose of weakening the state explosions, arson or other actions aimed at mass destruction of people, causing bodily harm or other harm to their health, the destruction or damage of objects that have important national economic or defense value, as well as committing for the same purpose actions aimed at radioactive contamination, mass poisoning, spread of epidemics, epizootics or epiphytoties (Article 113 of the Criminal Code of Ukraine);

3) movements of military columns; conducting activities to search for and destroy sabotage forces or enemy groups; land mine clearance measures; conducting combat and operational trainings;

4) providing with the operational search works; occurrence of the natural and man-made emergencies;

5) verification of readiness of forces and means to fulfill tasks on purpose;

6) ensuring security for the top military-political leadership of the state and representatives of the partner countries.

34 Про особливості державної політики із забезпечення державного суверенітету України на тимчасово окупованих територіях у Донецькій та Луганській областях : Закон України від 18 січн. 2018 р. № 2268-VIII. URL: https://zakon.rada.gov.ua/laws/main/2268-19 (дата звернення: 01.10.2018). 
All what is mentioned above gives reasons to distinguish the following features of the preventive actions of the police in the conditions of a joint operation:

1) mainly concerns preventive activities, i.e. specific preventive measures implemented by police officers, who are conditioned by the peculiarities of conducting a joint force operation, which requires rapid management decisions and operational measures. The implementation of prevention, which is part of the prevention actions of the police, takes some time to obtain the results of its' implementation;

2) is a set of measures, techniques and methods provided in a special legislative act that defines the conditions of public policy, particularly in the field of law enforcement, in the conditions of the operation of the joint forces;

3) the police carry out preventive measures aimed to prevent the activities of illegal armed groups and subversive groups, preventing the supply of weapons, ammunition and drugs, counteracting terrorist acts and sabotage, extremism, whereas the last one is the most characteristic for the territory of the Joint Force operation;

4) there are extended grounds for application and a list of preventive police measures;

5) determination of specific preventive measures that can be applied by the National Police depending on the occurrence of special order conditions commands the Chief of General Staff;

6) specifics of the application of certain preventive measures, as well as the extent of police powers, depend on the establishment of a special regime in the area of the united forces operations ${ }^{35}$.

The existence of specially designated areas covered by the special status and regime whereby law enforcement agencies acquire special powers, as well as the high potential level of danger during the united forces operations, necessitate continuous systematic monitoring. The state of law and order in which the operation of the joint forces is carried out depends to some extent on the quality of preventive activity by the national police.

\section{CONCLUSIONS}

Preventive activity of the police provides the implementation of a system of actions and preventive measures, as well as techniques, methods and

35 Аброськін В. В. Роль органів Національної поліції щодо забезпечення правопорядку в зоні проведення операції Об'єднаних сил. Забезпечення правопорядку на території проведення операції Об 'єднаних сил : матеріали Всеукр. наук.-практ. семінару, 12 жовт. 2018 р. Маріуполь : МДУ, 2018. С. 23-50. 
methods, carried out by authorized representatives of the police, to prevent offenses that may be committed by person or groups of people.

The use of police preventive measures during the united forces operations depends on a number of conditions, which are proposed to include: the geographical location of the territory, as well as the political and social situation within it; operational and criminogenic situation; crime rate; the number of police personnel, their level of professionalism, ability and skills; time allotted for this or that preventive process; the specific purpose for which they are pursued; categories of population living in the territory, etc.

It is established that preventive measures in the context of the united forces operations in individual regions are carried out by the police on a wider spectrum. In addition, police officers are empowered to implement public safety measures, including preventive activities, which are inherently broader than those provided for in Section V of the Law "On National Police".

\section{SUMMARY}

The article is devoted to the research of preventive activity of the National Police in the area of the united forces operations. Theoretical approaches to the definition and correlation of the concepts of "termination", "prevention" are investigated. The peculiarities of preventive activities carried out by the Ukrainian police in the context of the united forces operations have been clarified. The content of "preventive activity" is disclosed. The signs of preventive activity of the police are formulated. The classification of the prevention of offenses is made.

It is established that preventive measures in the context of the united forces operation in individual regions are carried out by the police on a wider spectrum. It is proved that police officers are vested with special powers during the implementation of measures of public security, including preventive activities, that are substantially broader than those, which provided for by section V of the Law of Ukraine "On the National Police".

\section{REFERENCES}

1. Конституція України : Закон України від 28 черв. 1996 p. № 254к/96-BP. URL: http://zakon.rada.gov.ua/laws/show/254к/96-BP (дата звернення: 03.10.2019).

2. Про боротьбу з тероризмом : Закон України від 20 бер. 2003 р. № 638-15. URL: https://zakon.rada.gov.ua/laws/show/638-15 (дата звернення: 15.10 .2019$)$. 
3. Про Національну поліцію : Закон України від 02 липн. 2015 р. № 580-VIII. URL: https://zakon.rada.gov.ua/laws/show/580-19 (дата звернення: 15.10.2019).

4. Про особливості державної політики із забезпечення державного суверенітету України на тимчасово окупованих територіях у Донецькій та Луганській областях : Закон України від 18 січн. 2018 р. № 2268VIII. URL: https://zakon.rada.gov.ua/laws/main/2268-19 (дата звернення: 01.10.2018).

5. Про затвердження рішення Ради національної безпеки і оборони України від 30 квітня 2018 року "Про широкомасштабну антитерористичну операцію в Донецькій та Луганській областях" : Указ Президента України від 30 квіт. 2018 p. URL: https://zakon.rada.gov.ua/ laws/show/116/2018 (дата звернення: 15.10.2019).

6. Про Стратегію сталого розвитку "Україна - 2020" : Указ Президента України від 12 січ. 2015 р. № 5/2015. URL: http://zakon2.rada.gov.ua/laws/show/5/2015 (дата звернення 15.10.2019).

7. Аброськін В. В. Роль органів Національної поліції щодо забезпечення правопорядку в зоні проведення операції Об'єднаних сил. Забезпечення правопорядку на території проведення операиіï Об'єднаних сил : матеріали Всеукр. наук.-практ. семінару, 12 жовт. 2018 р. Маріуполь : МДУ, 2018. С. 23-50.

8. Адміністративні правопорушення: демографічна та соціальна статистика. Правосуддя та злочинність. Державна служба статистика Украӥни : веб-сайт. URL: http://www.ukrstat.gov.ua (дата звернення: 15.10.2019).

9. Бандурка О. М. Профілактика злочинності. Вісник Південного регіонального иентру Національної академії правових наук Украӥни. 2014. № 1. C. 115-124.

10. Батраченко О. В. Форми правоохоронної діяльності національної поліції щодо забезпечення публічної безпеки та порядку в державі. Форум права. 2016. № 2. C. 5-10. URL: http://nbuv.gov.ua/j-pdf/FP_ index.htm_2016_2_3. (дата звернення: 15.10.2019).

11. Валєєв Р. Г., Чуріков Д. С. Превентивна діяльність поліцейських як стадія протидії злочинності. Актуальні питання протидї злочинності в сучасних умовах: вітчизняний та зарубіжний досвід : матеріали II Міжнар. наук.-практ. конф., 15 бер. 2013 р. Дніпро : Дніпропетр. держ. ун-т внутр. справ, 2018. С. 212-215.

12. Василенко В. А. Російсько-українська війна 2014 року: причини, перебіг та політико-правові оцінки. Украӥнський тиждень. 2014. № 42. C. $28-42$. 
13. Волокітенко I. О. Адміністративно-правовий статус підрозділів превентивної діяльності Національної поліції України. Visegrad Journalon Human Rights. 2016. № 6. Ч. 2. C. 42-46.

14. Горустович Ю. В. Основні оперативно-профілактичні заходи, спрямовані на забезпечення правопорядку у донецькому регіоні в умовах ООС. Забезпечення правопорядку на території проведення операції Об'єднаних сил : матеріали Всеукр. наук.-практ. семінару, жовт. 2018 р. Маріуполь : МДУ, 2018. С. 95-106.

15. Дідик Н. І. Превентивні функції в діяльності патрульної поліції. Вісник Луганського державного університету внутрішніх справ імені Е. О. Дідоренка. 2016. Вип. 2. С. 188-194.

16. Клюєв О. М. Сутність та місце профілактичних заходів у правоохоронній діяльності. Право і суспільство. 2013. № 6. С. 195-197.

17. Клюєв О. М. Форми та методи профілактичної діяльності органів внутрішніх справ на місцевому рівні. Форум права. 2007. № 1. C. 99-103. URL: http://nbuv.gov.ua/j-pdf/FP_index.htm_2007_1_19 (дата звернення: 15.10.2019).

18. Колесник С. П. Проблемні питання забезпечення правопорядку в зоні проведення операції Об'єднаних сил. Забезпечення правопорядку на території проведення операщії Об'єднаних сил : матеріали Всеукр. наук.-практ. семінару, 12 жовт. 2018 р. Маріуполь : МДУ, 2018. С. 85-94.

19. Кримінологія : підручник / Джужа О.М. та ін.; за заг. ред. О. М. Джужи. Київ : Юрінком Інтер, 2002. 416 с.

20. Макаренко О. М. Суб'єкти профілактики правопорушень. Право і Безпека. 2004. № 3 (3). С. 68-70.

21. Словник української мови : в 11 т. / голова редкол. І. К. Білодід. Київ : Наукова думка, 1976. Т. 7. 724 с.

22. Фелик В. І. Класифікація видів профілактичної діяльності Національної поліції України. Форум права. 2016. № 4. С. 313-316. URL: http://nbuv.gov.ua/j-pdf/FP_index.htm_2016_4_51 (дата звернення: 15.10.2019).

23. Фелик В. І. Профілактика правопорушень як особливий напрям діяльності Національної поліції України. Прикарпатський юридичний вісник. 2015. Вип. 3. С. 229-232.

Information about the author: Abroskin V. V., Doctor of Law, Rector, Odesa State University of Internal Affairs 1, Uspenska str., Odessa, 65000, Ukraine 


\section{PECULIARITIES OF ESTABLISHMENT OF INTERNATIONAL RESPONSIBILITY OF THE STATE FOR THE BEHAVIOR OF EXECUTIVE AUTHORITIES}

\section{Andreichenko S. S.}

\section{INTRODUCTION}

The primary and axiomatic rule, regarding the attribution of behavior for the purposes of State responsibility under international law - it is the principle that the conduct of a body of a State is regarded as an act of that State.

L. Oppenheim fairly pondered the question: "Since states are legal entities, whose internationally wrongful acts should be regarded as acts of the state and, therefore, as international offenses? To this question should be such an answer: firstly, all such actions, which committed by Heads of State or members of governments, acting as such, in that their actions are those of the State; secondly, all actions of officials or other persons, which is acting on orders or with the permission of governments. It is not an international offense an acts, which committed by Heads of State or members of government outside the scope their official duties, private entities which acting for themselves, not for the state"

T. Weiler, while giving a general description of the rule under consideration, noted that "this rule reflects the basic idea, that the state is an abstract concept. It can act only through individuals or legal entities, that is through the "body". In a sense the rule says nothing, apart from the observation, that when the state acts, it is the behavior of the state. There are two aspects to this rule that require further elaboration. The first being a public body; and the second notion, that any and all behavior of a public authority is assigned to the state"2.

The point of view, according to which actions or omissions of state bodies should be assigned to the state, was unanimously supported in the Governments' response to the Preparatory Committee of the 1930 Codification of International Law Conference. The Third Committee of the

1 Международное право: Мир. Перевод с английского. Т. 1 : Полут. 1 / Оппенгейм Л. ; под ред. : Крылов С. Б. (Предисл.) ; пер. : Лаутерпахт Г. М. : Иностр. лит., 1948. C. 336.

${ }^{2}$ Weiler T. International Investment Law and Arbitration : Leading Cases from the ICSID, NAFTA, Bilateral Treaties and Customary International Law . London : Cameron May, 2005. P. 29. 
Conference unanimously adopted, in the first reading Article 1, which provided for the international responsibility of a State in the event of any failure by its authorities to fulfill its international obligations ${ }^{3}$.

The rule, that according is attributes state behavior to its organs, which entails state responsibility in the event that such behavior is in breach of an international obligation of the state, reflects two main aspects. The first is the realization of the principle of unity of the state, from which it follows that the behavior of all state bodies, regardless of their functions and position in the state, belongs to the state. The second is that the international responsibility of the state may occur only, if the individual or legal entity acts as a public authority.

The principle, as a rule, restrains itself for the conduct of its persons acting, as clearly defined in international court decisions. The Permanent Chamber of International Justice further emphasized, that "States can act only with the help or through their agents or representatives". S. Olleson states: "Given the status of this rule, and of course its usual nature, there are a large number of cases, in which there is essentially no dispute, that the conduct of the authorities of the State is assigned to it; under these conditions, the question of attribution is unlikely to be avoided, and to some extent it is self-evident"

The International Law Commission in Article 4. from set of Articles 2001, defined: "The conduct of any body of a State shall be regarded as an act of that State under international law, whether that body exercises legislative, executive, judicial or any other functions, regardless of the position it occupies in the system of the State, and whether it is an authority of the central government or an administrative-territorial unit of the state". In their remarks on the draft articles, a number of governments have indicated, that the basis for attributing responsibility should be broad enough, that states cannot avoid liability, based on the formal definition of their bodies 5 .

Therefore, it is extremely important to correctly determine the status of bodies, whose actions are regarded as state behavior. The United Nations

${ }^{3}$ Commentaries to the draft articles on Responsibility of States for internationally wrongful acts adopted by the International Law Commission at its fifty-third session (2001). Report of the Commission to the General Assembly on the work of its fifty-third session / Yearbook of the International Law Commission. 2001. Vol. II, Part Two. P. 40.

${ }^{4}$ Olleson S. The impact of the ILC's articles on responsibility of states for internationally wrongful acts. London, British Institute of International and Comparative Law, 2009. P. 20.

${ }^{5}$ Report of the International Law Commission on the work of its fiftieth session, 20 April 12 June and 27 July - 14 August 1998. Official Records of the General Assembly. Fifty-third session. Supplement № 10. UN Doc. A/53/10 // Extract from the Yearbook of the International Law Commission. 1998. Vol. II (2). Para 363. P. 80. 
Commission on International Law has given serious consideration to this issue, considering it in the context of the problem of attribution to the state of conduct carried out by persons and bodies having the status of state according to its legal system.

\section{Definition of the term "public authority" for the purposes of international responsibility}

The term "public authority" conceptually means an entity, that forms part of the state's infrastructure. A state body is understood to mean a individual or legal entity, which carry out state power and through which the state functions. Since states are free, to organize their internal structure in whatever way they see fit, states are free to determine the bodies through, which they act.

The principle, according from which, all actions of all organs of a state can give rise to its international responsibility is equally recognized in the European human rights system. European Court of Human Rights in De Cubber v. Belgium (1987) clearly stated, that the state was responsible for the totality of its organs ${ }^{6}$. At the same time, the Court considered it necessary in a number of cases to emphasize that, in principle, it should not indicate, which national authority to bear responsible for a particular breach, that it merely establish the international responsibility of the State as a whole ${ }^{7}$.

This rule was also confirmed in the recent decision of the European Court of Human Rights Čikanović v. Croatia (2015), which concerned a breach of the right to a fair trial as a result of the national court's rejection of the applicant's claim for payment of wage arrears. The Court, citing earlier cases (Döşsemealtı Belediyesi v. Turkey, № 50108/06, 23 March 2010; Danderyds Kommun v. Sweden, № 52559/99, 7 June 2001; Yavorivskaya v. Russia, № 34687/02, 21 July 2005), noted that from the Court's point of view, the hierarchy between the various organs of the State is irrelevant when considering the case. Municipalities are public-law entities, which carry out state power and, whose acts or omissions, despite their degree of autonomy with respect to central authorities, may entail State liability under the Convention ${ }^{8}$.

Indeed, it can now be considered universally recognized that on international plan, the state to appear as a single unit, and one or another

\footnotetext{
${ }^{6}$ Case of de Cubber v. Belgium (Article 50). ECHR. Judgment of 14 September 1987 // EHRR. Vol. 13. P. 422.

${ }^{7}$ Гусейнов Л. Г. Международная ответственность государств за нарушения прав человека : [монография]. К. : Ин-т государства и права НАН Украины, 2000. С. 77.

${ }^{8}$ Čikanović v. Croatia. Judgment of the European Court of Human Rights of 5 February 2015. Para. 53 URL: http://hudoc.echr.coe.int/sites/eng/pages/search.aspx?i=001-150786.
} 
place of the organ in the system of state mechanism is significant, only from the point of view of internal law. Current international practice, also does not provide examples of references from separate states, to avoid liability for the "principle of autonomy" of state bodies".

International law recognizes, that the composition of states is obviously changing internally, and therefore, the definition of a public authority must necessarily be flexible. Thus, the idea of a state body is reduced to the basic concept of a subject, which is part of the state apparatus, regardless of the function it performs and regardless of the level of government.

Among the factors, influencing the definition of a state body, as such can be called: classification of establishment as a state body in accordance with the legislation of the state, participation of the state in financing the activity of this establishment, performance of state establishment, consideration of the subject of appointment of a person to a position and his subordination, state-owned entities.

At the same time, a state's own definition of a state body cannot be an indicative criterion for establishing, that it is a state body, and the conception of a state body for attribution purposes is predetermined by the principles of international law alone, since it is inadmissible to evade international liability by reference to internal law, which recognizes or does not recognize a particular entity, as a public authority.

\section{Features of attribution to the state of behavior of executive bodies}

Most of the actions, that became a reason for responsibility, come out from the executive branch, which provides the most direct exercise of state power. According to statements LG Huseynov, "there is no doubt that human rights and freedoms are mainly violated - and this is clearly evidenced by the huge flow of individual (including interstate) complaints, coming to interstate human rights institutions - by various acts of executive structures of the state. The fact is that, it is the branch of state power that, based on its functional purpose in the mechanism of the state, most often applies legislation and, accordingly, carries out a variety of activities, daily encountering individuals".

The jurisprudence of the Strasbourg authorities clearly illustrates the situation, that a violation of human rights is to a large extent a consequence of not a law itself, but a specific measure or decision taken by a relevant body, or official to enforce this law. So, the European Commission and the European

\footnotetext{
${ }^{9}$ Мазов В. А. Ответственность в международном праве : проблемы кодификации и прогрессивного развития норм и принципов международно-правовой ответственности. М. : Юрид. лит., 1979. С. 48.
} 
Court of Human Rights have in different years, considered claims of administrative detention, government decrees for compulsory study of certain subjects in schools, permission for expropriation and prohibition of construction work, interception of postal and telephone communications, by post services on the basis of regulating this sphere of legislative provisions, etc.

It is especially meaningful, when considering the issue that related with attribution to the state of the conduct of executive bodies is the activities of foreign relations bodies, which are official representatives of the state in international relations and, due to the carried out of their own functions, may lead to violation of the international obligations of the state, which entails the onset of international responsibility of the state (e.g. violation of the laws and customs of the host country by diplomatic agents). Most often, the state to bear liability for the actions or omissions of its executive bodies: ministries and agencies, army and police units, border and special services, down to the lower level of the executive branch.

In international doctrine and practice, was discussed the question whether on the international responsibility of the state a provisions of any body, in the structure of the state apparatus. E. Borchard believed, that only the behavior of higher authorities can be assigned to the state. This point of view has become widespread in American international law literature (Ch. Fenwick), G. von Glahn, and is reflected in Article VII (b) of the Harvard Project in 1929.

Relying on the International Arbitration Practice of 1850-1914, E. Borchard assumed the responsibility of the state for the behavior of its lower ranking bodies, only when it was directly or indirectly endorsed by higher authorities, for example when they did not take the necessary precautionary measures, whether they refuse to punish the guilty, or not give the victim access to court at all ${ }^{11}$.

An explanation of this concept can be seen in the fact, that international law at that time, rarely reached lower levels of government, except in a cases of violation of the rights of foreigners. But for these cases was provided a special order. Its role in spreading the concept under consideration in the United States played also features of the American legal system, which, unlike, for example, from European continental legal systems, often involves relatively unlawful actions of government employees, and especially lower-level officials, the

${ }^{10}$ Гусейнов Л. Г. Международная ответственность государств за нарушения прав человека : [монография] / Л. Г. Гусейнов. К. : Ин-т государства и права НАН Украины, 2000. C. 90.

${ }^{11}$ Borchard E. The Diplomatic Protection of Citizens Abroad or, The law of international claims. New York: The Banks law publishing co., 1915. P. 185-189. URL: https://archive.org/ stream/diplomaticprotec00borcrich\#page/n3/mode/2up. 
possibility of personally blaming an individual - the body, rather than being accused of violating the administration of the state as such ${ }^{12}$.

It is interesting fact, that during the 1930 Hague Conference on the Codification of International Law, a proposal was contributed to establish, that in the event of acts or omissions of lower-level officials, the State would not be held internationally responsible, if it recognized the wrongful conduct of the guilty official and will be punish him. However, this proposal was rejected ${ }^{13}$.

International arbitration practice has enough consistently adhered to the theory, that the behavior of bodies and officials at any level is attributed to the state. Founded by Mexico, and the United States in 1923, the General Commission of the claims in consider the case Roper, was disagreed with Mexico's position of the claims in the case Roper, disagreed with Mexico's position, which argued that the state was not responsible for the actions of the police, since there is a rule of international law, according to which the state is not responsible for the behavior of the lower level bodies.

In 1927, the Commission with decision found Mexico responsible. It was noted that "a clearly-established general principle requires, that each and every time when the state fails to fulfill its obligations, adopted within under international law in connection with the conduct, that deserves punishment one of the citizens (who are in her service), regardless of the position of the latter or his rank within internal law, it's bear liability for the wrongful acts of its officials" $" 14$.

The Panama Government, referring to the fact, that police agents are not normally regarded, as "power of the state," also sought to avoid liability for the wrongful conduct of lower-ranking officials, before the Panama-US General Commission on Claims in the case of Cecelia Dexter Baldwin, Administratrix of the Estate of Harry D. Baldwin, and Others (United States) v. Panama (1933). However, the Commission found Panama responsible in the decision on a case ${ }^{15}$.

The issue about a position administrative organ in apparatus of the state was violated in Ireland v. The United Kingdom (1978). In the present case, the Government of Ireland appealed to the European Commission on Human

12 Third Report on State responsibility, by Mr. Roberto Ago, Special Rapporteur, the internationally wrongful act of the State, source of international responsibility. A/CN.4/246 and Add. 1-3 // Yearbook of the International Law Commission. 1971. Vol. II, Part One. P. 62.

${ }_{13}$ Курис П. М. Международные правонарушения и ответственность государства. Вильнюс : Минтис, 1973. С. 173.

14 Лукашук И. И. Право международной ответственности. М. : Волтерс Клувер, 2004. C. 113 .

${ }^{15}$ Cecelia Dexter Baldwin, Administratrix of the Estate of Harry D. Baldwin, and Others (United States) v. Panama (1933) // Reports of International Arbitral Awards. Vol. VI. P. 328. 
Rights, complaining about the UK's violation of various articles of the Convention in Northern Ireland, in particular Art. 3, Art. 5, Art. 6, Art. 14, as well as Art. 15. The essence of the complaint was, that many persons deprived of their liberty, on the basis of extraordinary rules were subjected to torture, or other treatment contrary to Art. 3 of the Convention. One of the arguments of the defendant State, was that the higher administrative authorities not known about practices, used by the police and security forces of Northern Ireland.

In its judgment, the court upheld the principle, that the provision of an administrative authority was irrelevant for attributing unlawful conduct to a State and found, that the action and inaction of a competent authority with respect to its subordinates, could give rise to State liability within European Convention."The Convention not only obliges the higher authorities of the Contracting States, to respect from its side embodied in it the rights and freedoms ; as referred to in Article 14 (Article 14) and in the English text of Article 1 (Article 1) ("shall secure"), the Convention also provides that in order to ensure the exercise of these rights and freedoms, these authorities must prevent or eliminate any breach at lower levels"16.

In the case of Guillermo Ignacio Dermit Barbato and Hugo Haroldo Dermit Barbato v. Uruguay $(1981)^{17}$, considered by the United Nations Human Rights Committee, stated that the victim of the abuse had died, as a result of acts of in humane treatment and torture during its detention. However, the defendant State, denied this and stated that the victim had committed suicide. In its decision, the Committee found that, in all circumstances, the power of defendant State's authority to bear liability, either for action or omission, for failing to take adequate measures, to protect the life of the victim, as required by Article 6 (1) of the Covenant.

Another confirmation of the thesis, that the state attributes the behavior of lower-level executive bodies is the case of McCann and Others v. United Kingdom (1995). In this case from Intelligence data, the British and Gibraltar authorities have concluded, that a group of the Irish Republican Army would commit a terrorist act by laying a bomb with a remote control in a car.

The Operation management was assigned to the commander of the Special Airborne Service (SAS). Under the process detention, thinking that McCann and Farrell, and later Savage, were trying to use a remote control

\footnotetext{
${ }^{16}$ Ireland v. the United Kingdom. Judgment of European Court of Human Rights of 18 January 1978 // EHRR. Vol. 2. Para. 239.

${ }^{17}$ Guillermo Ignacio Dermit Barbato and Hugo Haroldo Dermit Barbato v. Uruguay. Communication № 84/1981. UN Doc. A/38/40 // Yearbook of the Human Rights Committee. 1983-1984. Vol. I. P. 419.
} 
mechanism to detonate a bomb embedded in the car, SAS officers shot them all at close range. None of the three suspects were identified with any weapons or remote control. The inspection found that the car, previously parked by Savage, also had no explosive device or bomb.

In deciding on the conformity of the applied force of Art. 2 of the 1950 Convention, the European Court of Human Rights carefully examined not only the question of the strictness of the force, used by military personnel with aim to protect people from unlawful violence, but also whether the government planned and conducted an anti-terrorist operation, so as to minimize (as far as possible) the use of force that led to life deprivation. To sum up, the Court noted, that depriving three terrorists of their lives did not constitute the use of force absolutely necessary, to protect people from unlawful violence. Accordingly, the Court held that the United Kingdom had breached Art. 2 of the 1950 Convention ${ }^{18}$.

Due to the actions of officials and public authorities lower-level, there is sometimes the question of applying the rule of exhaustion of local remedies. Therefore, it should be emphasized, that this rule applies only to foreign individuals and legal entities, under the jurisdiction of the state. According to this rule, they must use all available local remedies, to protect their rights, before applying to the State of nationality with requesting to grant diplomatic protection. If the actions of local authorities directly violate the international rights of the state, then the rule of exhaustion of local means does not apply.

In such a case, there is not arise a question of diplomatic protection. An example, give a case about a violation of the diplomatic immunity of a representative of a foreign country by a local authority. This provision was confirmed in 1956 by the Institute of International Law, which pointed to the existence of a principles of international law, which excludes the application of the rule on the exhaustion of local remedies in cases, where the act violates a person enjoying special international-legal protection ${ }^{19}$.

It should be agree with P.M. Kuris on the practical value of the rule of exhaustion of domestic remedies in the field of state liability for damage, caused to its territory by foreigners. It really reduces the number of international claims, from the side by foreign countries, whose citizens have been harmed, and in this sense plays a positive role in strengthening the principles of respect state sovereignty and non-interference. There is no

${ }^{18}$ McCann and Others v. United Kingdom. Judgment of the European Court of Human Rights of 27 September 1995. Paras. 192-214. URL: http://hudoc.echr.coe.int/sites/eng/ pages/search.aspx $? \mathrm{i}=001-57943$.

19 Лукашук И. И. Право международной ответственности. М. : Волтерс Клувер, 2004. C. 114. 
need, to bring to the international arena, what can be resolved with help, through the means provided by national law. This rule is fully in line with international law, which requires respect by foreigners of the laws of the host country ${ }^{20}$.

\section{Responsibility of the state for the behavior of persons from the composition of armed forces}

One of the actual aspects of attribution to the state of the behavior of executive bodies is the question of attribution actions of persons, from the composition of armed forces. J. Crawford writes, that "the most obvious manifestation of the executive power is the actions of the armed forces, which in the presence of armed conflict, are in all cases appropriated to the state, and entail international responsibility of the state" 21 .

In the past, there have been different approaches, to address this question. So, for example, J.-P. Queneudec noted, that before the beginning of the twentieth century, the arbitral awards distinguished, between acts of soldiers performed in the presence of an officer and independent acts of members of the staff. If in the first case, the state was held responsible, then in the second case, the actions of the members of the ordinary staff, were equated with the behavior of private individuals ${ }^{22}$.

For now, generally recognized is the principle of state responsibility, for all unlawful acts of the armed forces committed during wartime. Long existed principle of customary international law, established in Article 3 of the Hague Convention (IV) 1907 and confirmed in Article 91 of Additional Protocol I, is the rule, according to which the state is responsible for all acts committed by persons, who are in composition its armed forces. This principle, its the application of the general rule on the responsibility of the states for international illegal acts, by virtue of which state is responsible, for the actions of its bodies.

The Armed Forces are considered to be a state body, like any other executive, legislative or judicial power. The application of this general principle of responsibility in international humanitarian law has been reflected in four Geneva Conventions, which indicate the existence of State liability along with the requirement prosecution of persons for serious violations. The principle that, in addition to individual criminal liability,

${ }^{20}$ Курис П. М. Международные правонарушения и ответственность государства. Вильнюс : Минтис, 1973. С. 175.

${ }^{21}$ Crawford J. State Responsibility : The General Part. Cambridge : Cambridge University Press, 2013. P. 119.

${ }^{22}$ Queneudec J.-P. La Responsabilite Internacionale de l'Etat pour les Fauters Personnelles de ses agents. Paris : Librairie générale de droit et de jurisprudence, 1966. P. 184-185. 
there is a State responsibility is also confirmed in the Second Protocol to the Hague Convention for the Protection of Cultural Property (1999).

A number of military statutes contain provisions, stating that the state is responsible for violations of international humanitarian law. Some of these charters, clearly refer to actions taken by persons in composition the armed forces of the state, others in more general terms, speak of responsibility for serious violations or military crimes, without specifying to whom such actions should be carried out in order to be attribute to the State (for example, the military statutes of Argentina, the United Kingdom, Germany, Spain, Canada, Colombia, Nigeria, the Netherlands, New Zealand, the United States, Switzerland, Yugoslavia).

There is also a national existing law, that confirms this principal. In its decision in the Eichmann case of 1961, the Jerusalem District Court referred to the unlawful acts, committed by the accused in Germany as "acts on behalf of the state". Moreover, in the case of the payment of reparations in 1963, the Federal Supreme Court of Germany, referred to the "principle of public international law, according to which the State - party to the conflict is also responsible for actions which are not in accordance with public international law "and committed by its citizens in connection with conduct hostilities. In a case Distomo (2003), the same German court affirmed, that the responsibility of states for internationally wrongful acts, committed during hostilities "includes the responsibility of the state for the actions of all persons from the composition armed forces"23.

In J.T. case, which consider by the Hague (Netherlands) District Court in 1949 , talks about required the return of money, that had disappeared during the arrest a person by members of the Dutch Liberation Movement during World War II and, as it later emerged, was taken by the police. This case, still one confirmation of the principle, according to which states bear liability for violations of international humanitarian law, that committed by state bodies.

The official statements and practice, reflected in the reports also testify to the correctness of such a finding (e.g. statements by Austria, Argentina, United Kingdom, Israel, Indonesia, Iran, China, Mexico, Norway, Pakistan, Peru, Solomon Islands, USA, Turkey, and Yugoslavia), as well as the practice of Israel and Spain, reflected in the reports) ${ }^{24}$.

23 Henckaerts J.-M., Doswald-Beck L., Alvermann C. Customary International Humanitarian Law : Volume 1, Rules. / J.-M. Henckaerts, New York : Cambridge University Press. 2005. P. 531.

${ }^{24}$ Henckaerts J.-M., Doswald-Beck L., Alvermann C. Customary International Humanitarian Law : Volume 1, Rules. / J.-M. Henckaerts, New York : Cambridge University Press. 2005. P. 532. 
International judicial institutions also stand in the position of attributing to the state the behavior of its armed forces.

United Nations International Court of Justice in Jurisdictional Immunities of the State, Germany v. Italy (2012) stated: "If the crimes are committed by agents of the state, during an armed conflict, the state must take responsibility for the unlawful actions of its agents, and ensure compensation for the victims. Such compensation is usually made, through interstate mechanisms, or with help through special means established by the state responsible for the violation" 25 .

Another example of the State's responsibility, for the conduct of the armed forces is a case about armed action on the territory of the Congo. (Armed Activities on the Territory of the Congo) (Congo v. Uganda) (2005), which was considered by the United Nations International Court of Justice ${ }^{26}$. In this case the Court noted, that the behavior of the UPDF (Uganda People's Defense Force) is generally clearly linked to Uganda and is a behavior of a state bodies.

According to the established principle of international law, which is customary character, "the behavior of any body of a State should be regarded, as an act of that State." In the Court's view, in force a military status and the functions of Uganda soldiers in the DRC, their behavior is attributed to Uganda. Therefore, the allegation that these persons did not act as persons which carry out a state powers in specific circumstances is not evidence.

Furthermore, it does not matter to attribute their behavior to Uganda, whether the UPDF staff acted contrary to the instructions or exceeded their authority. In accordance with established rule of customary character, as this reflected in Article 3 of the Fourth Hague Convention on the Laws and Customs of the Land War of 1907, as well as in Article 91 of Protocol 1 to the Geneva Conventions of 1949, the party in armed conflict shall be responsible, for all actions of persons forming part of its armed forces ${ }^{27}$.

More earlier case Youmuns concerned a case, where Mexican troops introduced by the government to prevent an attack on three US citizens, not only dispersed the attacking crowd, but also take part in massive disturbances. On the grounds of that the soldiers were on duty, and under the

25 Jurisdictional Immunities of the State, Germany v. Italy. Judgment of the ICJ of 3 February 2012. Para. 17. URL: http://www.icj-cij.org/docket/index.php?p1=3\&p2=3\&case= $143 \& \mathrm{p} 3=4$.

26 Armed Activities on the Territory of the Congo (Congo v. Uganda). Judgment of 19 December 2005 // ICJ Reports. 2005. P. 168.

27 Armed Activities on the Territory of the Congo (Congo v. Uganda). Judgment of 19 December 2005 // ICJ Reports. 2005. Para. 214. 
command of a senior officer at the time, Mexico was found responsible for the deaths of Americans. If the troops wore civilian clothes, and participated in a riot, really as private citizens, Mexico probably wouldn't be held accountable ${ }^{28}$.

Indicated principle has been repeatedly has been confirmed by the European Commission on Human Rights in considering a number of interstate statements, against Turkey in connection with Cyprus events. "... the responsibility of Turkey is due, to the fact, that the Turkish armed forces have violated the rights and freedoms set out in the Convention by their actions and omissions ...."29. The International Criminal Tribunal as to former Yugoslavia, in its decision in a case A. Furundzhija's 1998 and in a decision of appeal case Tadich 1999, assumed that the state was responsible for the actions of its armed forces ${ }^{30}$.

In the case Hassan v. the United Kingdom (2014), to considering by European Court of Human Rights, the applicant claimed, that his brother had been arrested and detained by British troops in Iraq, and subsequently was found dead in unknown circumstances. The applicant complained, that the arrests and detentions were arbitrary, unlawful and carried out in the absence of procedural safeguards, and that the authorities of the United Kingdom had failed to investigate the circumstances of detention, ill-treatment and death ${ }^{31}$.

In this case, the Court found that, given the facts which was handle, there was no evidence to suggest, that Tarek Hasan to fail ill-treated while in the camp, that for the defendant State would arise a obligation, to conduct a official investigation. There is also no evidence, that the United Kingdom organs in any way, - directly or indirectly - to had responsibility, for the death of Tarek Hassan, which occurred about four months after he was released from Camp Bukka in a remote part of the country not controlled by forces The United Kingdom. In the absence of any evidence of the involvement of United States Government agents till the death, or even of any evidence that the death occurred in a UK controlled territory, none obligation to investigate under Article 2 arises.

${ }^{28}$ Crawford J. State Responsibility : The General Part. Cambridge : Cambridge University Press, 2013. P. 120.

${ }^{29}$ Гусейнов Л. Г. Международная ответственность государств за нарушения прав человека : [монография]. К. : Ин-т государства и права НАН Украины, 2000. С. 92.

${ }^{30}$ Henckaerts J.-M., Doswald-Beck L., Alvermann C. Customary International Humanitarian Law : Vol. 1, Rules. / J.-M. Henckaerts, New York : Cambridge University Press. 2005. P. 532.

${ }^{31}$ Hassan v. the United Kingdom. Judgment of the European Court of Human Rights of 16 September 2014. Para. 3 URL: http://hudoc.echr.coe.int/sites/eng/pages/search.aspx?i=001153724 . 
The Court stated that the complaints under Articles 2 and 3 of the Convention were manifestly ill-founded within the meaning of Article 35 $\S 3$ (a) of the Convention, and should be recognize inadmissible, according to Article $35 \S \S 3$ and 4 of the Convention ${ }^{32}$.

The state is also responsible for the omission of its organs, if they are obliged to take action, for example, commanders and other superiors are obliged to take measures, to prevent or punishment for its committed. This principle is reflected in Article 2 of the Article on States Responsibility, which states that an internationally unlawful act, may consist of "acts or omissions".

In the case of 1925, concerning the claims of Great Britain in Spanish Morocco, Judge Max Huber held that a State which had not conscientiously acted in its duty, to prevent unlawful acts or to punish members of armed groups for their perpetration was responsible ${ }^{33}$. In the case of the Essen Lynch Court, which considering by UK Military Court in Essen, German military guards were convicted for failing to protect prisoners of war Allied nations from the onslaught of the crowd. In the Velazquez Rodriguez case, the Inter-American Court of Human Rights ruled, that the state would be held responsible for the actions of armed groups, if it did not conduct a serious investigation into the actions, in a result which violated the individual's rights. A similar thought was expressed by the African Commission on Human Rights, and Nations in connection with the killings and ill-treatment of the armed conflict in Chad.

\section{CONCLUSIONS}

All actions and acts of executive bodies should be based on the law, not contradict it, aimed at the implementation of the law. The problem of attribution to the state of the behavior of the executive bodies, and of the general responsibility of the state for the activity of its executive bodies has always occupied a central place in the studies, related to the issues of international - legal responsibility. This was explained, not only by the fact, that in the system of named bodies includes a variety of bodies, and officials, ranging from the government, and ending with the ordinary police, but also the role played by the state responsibility for the damage, caused to the person and property of foreigners. Most often, violations of the rights of foreigners occurred, through the behavior of various levels of the executive branch.

\footnotetext{
${ }^{32}$ Hassan v. the United Kingdom. Judgment of the European Court of Human Rights of 16 September 2014. Para. 3 URL: http://hudoc.echr.coe.int/sites/eng/pages/search.aspx?i=001153724 .

33 Affaire des biens britanniques au Maroc espagnol (Espagne contre RoyaumeUni) (1925) // Reports of International Arbitral Awards. Vol. II. P. 642-646.
} 
Among the factors, influencing the definition of a state body as such can be called: classification of establishment as a state body, in accordance with the legislation of the state, participation of the state in financing the activity of this establishment, performance of state functions, consideration of the subject of appointment of a person to a position and his subordination, the existence of state control of the activity of establishment, state-owned entities.

A state's own determination of a state body cannot be an indicative criterion, in recognizing a particular entity, as a state for attribution purposes, since it is inadmissible to evade international liability by reference to internal law. The conception of the state body, for the purpose of attribution is determined by the principles of international law.

International doctrine and practice, testify to the existence in international law of a established principle, according to which the state is responsible for the actions, and omissions of all its executive bodies, regardless of their hierarchy. This principle is particularly sound in modern conditions in the context of attribution to the state of the illegal behavior of its armed forces.

\section{SUMMARY}

Among the factors influencing the definition of a state body as such can be called: classification of establishment as a state body in accordance with the legislation of the state, participation of the state in financing the activity of this establishment, performance of state functions, consideration of the subject of appointment of a person to a position and his subordination, the existence of state control of the activity of establishment, state-owned entities.

A state's own determination of a state body cannot be an indicative criterion in recognizing a particular entity as a state for attribution purposes, since it is inadmissible to evade international liability by reference to internal law. The conception of the state body for the purpose of attribution is determined by the principles of international law.

International doctrine and practice testify to the existence in international law of a established principle according to which the state is responsible for the actions and omissions of all its executive bodies, regardless of their hierarchy. This principle is particularly sound in modern conditions in the context of attribution to the state of the illegal behavior of its armed forces. 


\section{REFERENCES}

1. Affaire des biens britanniques au Maroc espagnol (Espagne contre RoyaumeUni) (1925) // Reports of International Arbitral Awards. Vol. II.

2. Armed Activities on the Territory of the Congo (Congo v. Uganda). Judgment of 19 December 2005 // ICJ Reports. 2005.

3. Borchard E. The Diplomatic Protection of Citizens Abroad or, The law of international claims. New York: The Banks law publishing co., 1915. URL: https://archive.org/stream/diplomaticprotec00borcrich\#page/n3/mode/ 2up.

4. Case of de Cubber v. Belgium (Article 50). ECHR. Judgment of 14 September 1987 // EHRR. Vol. 13.

5. Cecelia Dexter Baldwin, Administratrix of the Estate of Harry D. Baldwin, and Others (United States) v. Panama (1933) // Reports of International Arbitral Awards. Vol. VI.

6. Čikanović v. Croatia. Judgment of the European Court of Human Rights of 5 February 2015. URL: http://hudoc.echr.coe.int/sites/eng/ pages/search.aspx?i=001-150786.

7. Commentaries to the draft articles on Responsibility of States for internationally wrongful acts adopted by the International Law Commission at its fifty-third session (2001). Report of the Commission to the General Assembly on the work of its fifty-third session // Yearbook of the International Law Commission. 2001. Vol. II, Part Two.

8. Commission Nationale des Droits de l'Homme et des Libertes v. Chad, African Commission on Human and Peoples' Rights, Comm. No. 74/92 (1995). URL: http://www1.umn.edu/humanrts/africa/comcases/ 74-92.html.

9. Crawford J. State Responsibility : The General Part. Cambridge : Cambridge University Press, 2013.

10. Guillermo Ignacio Dermit Barbato and Hugo Haroldo Dermit Barbato v. Uruguay. Communication № 84/1981. UN Doc. A/38/40 // Yearbook of the Human Rights Committee. 1983-1984. Vol. I.

11. Hassan v. the United Kingdom. Judgment of the European Court of Human Rights of 16 September 2014. URL: http://hudoc.echr.coe.int/ sites/eng/pages/search.aspx?i=001-153724.

12. Henckaerts J.-M., Doswald-Beck L., Alvermann C. Customary International Humanitarian Law : Volume 1, Rules. / J.-M. Henckaerts,New York : Cambridge University Press. 2005.

13. Ireland v. the United Kingdom. Judgment of European Court of Human Rights of 18 January 1978 // EHRR. Vol. 2. 
14. Jurisdictional Immunities of the State, Germany v. Italy. Judgment of the ICJ of 3 February 2012. URL: http://www.icj-cij.org/docket/ index.php?p1 $=3 \& \mathrm{p} 2=3 \&$ case $=143 \& \mathrm{p} 3=4$.

15. McCann and Others v. United Kingdom. Judgment of the European Court of Human Rights of 27 September 1995. URL: http://hudoc.echr.coe.int/sites/eng/pages/search.aspx?i=001-57943.

16. Olleson S. The impact of the ILC's articles on responsibility of states for internationally wrongful acts. London, British Institute of International and Comparative Law, 2009.

17. Queneudec J.-P. La Responsabilite Internacionale de l'Etat pour les Fauters Personnelles de ses agents. Paris : Librairie générale de droit et de jurisprudence, 1966.

18. Report of the International Law Commission on the work of its fiftieth session, 20 April - 12 June and 27 July - 14 August 1998. Official Records of the General Assembly. Fifty-third session. Supplement № 10. UN Doc. A/53/10 // Extract from the Yearbook of the International Law Commission. 1998. Vol. II (2).

19. The Essen Lynching Case : Trial of Erich Ileyer and Six Others. British military court for the trial of war criminals, Essen. Judgment of 21-22 December 1945 // Law-Reports of Trials of War Criminals. The United Nations War Crimes Commission. Vol. I, London : HMSO, 1947. URL: http://www.eccc.gov.kh/sites/default/files/documents/courtdoc/00222779-0022 2784_0.pdf.

20. Third Report on State responsibility, by Mr. Roberto Ago, Special Rapporteur, the internationally wrongful act of the State, source of international responsibility. A/CN.4/246 and Add. 1-3 // Yearbook of the International Law Commission. 1971. Vol. II, Part One.

21. Velasquez Rodriguez v. Honduras (1988) // Inter-American Court of Human Right. Judgment of 29 July 1988. Ser. C. № 4 (1988).

22. Weiler T. International Investment Law and Arbitration : Leading Cases from the ICSID, NAFTA, Bilateral Treaties and Customary International Law. London : Cameron May, 2005.

23. Гусейнов Л. Г. Международная ответственность государств за нарушения прав человека : [монография]. К. : Ин-т государства и права НАН Украины, 2000.

24.Курис П. М. Международные правонарушения и ответственность государства. Вильнюс : Минтис, 1973.

25. Лукашук И. И. Право международной ответственности. М. : Волтерс Клувер, 2004. 
26. Мазов В. А. Ответственность в международном праве : проблемы кодификации и прогрессивного развития норм и принципов международно-правовой ответственности. М. : Юрид. лит., 1979.

27. Международное право : Мир. Перевод с английского. Т. 1 : Полут. 1 / Оппенгейм Л. ; под ред. : Крылов С. Б. (Предисл.) ; пер. : Лаутерпахт Г. М. : Иностр. лит., 1948.

\section{Information about the author:} Andreichenko S. S.,

Doctor of Sciences in Law, Associate Professor, Professor at the Department of International Law and Comparative Law, International Humanitarian University 33, Fontanska Road str., Odessa, 65009, Ukraine 


\section{ORGANIZATIONAL AND LEGAL BASIS OF COOPERATION OF UKRAINE AND THE EUROPEAN UNION IN THE LAW ENFORCEMENT FIELD ORGANIZATIONAL AND LEGAL BASIS OF COOPERATION OF UKRAINE AND THE EUROPEAN UNION IN THE LAW ENFORCEMENT FIELD}

\section{Bondar V. V.}

\section{INTRODUCTION}

In connection with Ukraine's determination of a strategic goal integration into the European Union, including membership in this international association - it is an important task to bring national legislation in line with Community law, which causes reform of the legal system of the country as a whole. The path to European integration involves the real protection and protection of fundamental human rights and freedoms, the creation of a rule of law, social and democratic state that will have a worthy place in the world community.

This process, among other things, involves a full-scale reform of Ukraine's legal system based on the principles and standards established at the pan-European level on the basis of modern democratic international law as a result of the activities of European regional international organizations. This is the reason for our country's accession to the European legal space, which is defined by the internal normative acts of Ukraine as a necessary condition for integration of Ukraine into Eurospace and other European structures.

Today, our country is actively seeking to create an extensive, reliable and effective system of interaction between national law enforcement and other competent authorities and officials with foreign counterparts in investigating crimes of an international nature. In this regard, it is especially urgent to find and implement new organizational and managerial approaches in the field of international cooperation of these entities, while taking into account all the most important standards, principles and norms developed by the world community in this field.

The experience of foreign law enforcement in this field is of great theoretical and practical importance. After all, foreign countries have gained considerable experience today in working together to solve crimes of an international nature and to counter international crime. 


\section{Prerequisites of the need for cooperation of Ukraine and the European Union in the law enforcement field}

This process, among other things, involves a full-scale reform of Ukraine's legal system based on the principles and standards established at the pan-European level on the basis of modern democratic international law as a result of the activities of European regional international organizations.

Today, our country is actively seeking to create an extensive, reliable and effective system of interaction between national law enforcement and other competent authorities and officials with foreign counterparts in investigating crimes of an international nature. In this regard, it is especially urgent to find and implement new organizational and managerial approaches in the field of international cooperation of these entities, while taking into account all the most important standards, principles and norms developed by the world community in this field. The experience of foreign law enforcement agencies in this field is of crucial theoretical and practical importance. After all, foreign countries have gained considerable experience today in working together to solve crimes of an international nature and to combat international crime.

It should be noted that various aspects of cooperation in different spheres of public life were investigated by: A. Aksenov, M. Anufriev, V. Tropin, V. Bolotova, M. Kamlyk, Y. Sveventseva, O. Bandurka, A. Gliev, D. Grebelsky, I. Gutkin, K. Yermakov, N. Yablokov, I. Gerasimov, A. Zagorny, L. Drapkin, I. Mozhayeva, V. Stepanov, O. Vinogradova, M. Pashkovsky, V. Grebenyuk, V. Malyarenko., S. Kravchuk, V. Maksimenko and others.

The theoretical basis of the study is the work of well-known scientists in the field of administrative law and government, organization of cooperation in the field of law enforcement, such as: Averyanov, O.F. Andriyko, I.V. Aristova, O.M. Bandura,

D.M. Bahrach, V.V. Belevtseva, Yu.P. Bityak, V.T. Bilous, I.L. Borodin, A.S. Vasilyev, Yu.A. Vedernikov, D. Witfield, O.V. Vodianikov, I.P. Golosnichenko, I.I. Gorynetsky, V.S. Guslavsky, E.V. Dodin, G.V. Druzenko, V.K. Running around, V.O. Overgrown, R.A. Kalyuzhnyi, Yu.M. Kapitsa, S.V. Kivalov, V.V. Kovalenko, Yu.M. Kozlov, T.O. Kolomoets, V.K. Kolpakov, A.T. Komzyuk, V.V. Kopiyka, O.P Korenev, A.M. Kuchuk, V.I. Kurilo, E.V. Kurinny, O.I. Lezhenin, V.A. Lipkan, O.V. Negodchenko, N.R. Nizhnik, D.M. Ovsyanko, V.I. Olefir, I.L. Oliynyk, O.I. Ostapenko, I.M. Pakhomov, E. Pashkovsky, V.P. Petkov, S.V. Petkov, V.V. Polovnikov, D.V. Priymachenko, T.O. Protsenko, O.P. Ryabchenko, L.A. Savchenko, V.M. Selivanov, V.F. Sirenko, O.F. Skakun, Yu.M. Starilov, V.V. Stashis, V.Ya. Tatsiy, O.D. Tikhomirov, M.M. Tishchenko, O.V. Tyurina, 
V.G. Fathutdinov, T.O. Cymbalist V.V. Tsvetkov, V.P. Chaban, D.V. Yagunov, M.K. Yakimchuk et al.

These and other lawyers have made a significant contribution to the development of this cooperation. However, a number of issues remain fragmented and require scientific study, and this fully applies to cooperation with foreign law enforcement and competent authorities, officials of foreign countries, international organizations

The purpose of the study is the legal foundations of Ukraine's EU integration process in the field of law enforcement ${ }^{1}$.

The establishment of a rule of law in Ukraine has an increasing prospect both in the light of the principles of the current Constitution and in the light of the implementation of the national course on European integration. Ukraine's European aspirations require the pursuit of appropriate policies and implementation and development on the national basis of the democratic norms and values inherent in the countries of the European Union ${ }^{2}$.

Since Ukraine has announced its intention to integrate into the European community, one way of achieving this is to harmonize Ukrainian and European law in general and the legal rules governing law enforcement, in particular. Achieving this goal is possible only when mastering the content of European law in this field, as well as some theoretical terms and concepts (European integration, standards of law enforcement agencies, etc.). One, and perhaps the main of the problems of this process is the haphazard approach to this problem ${ }^{3}$.

With the adoption of the strategy of integration of Ukraine into the European Union, the implementation of the Partnership and Cooperation Agreement into national legislation was initiated. In order to fulfill the main provisions of the strategy, the Cabinet of Ministers approved the concept of adaptation of the legislation of Ukraine to the legislation of the European Union. The President of Ukraine signed the Decree "On a Sustainable Development Strategy "Ukraine 2020", which aims at introducing European standards of living in Ukraine and entering Ukraine into the leading positions in the world.

Speaking for the signing of various treaties, international cooperation between states in the humanitarian field today is characterized by a

\footnotetext{
${ }^{1}$ Свропейський Союз: Консолідовані договори. Київ. Port-Royal, 1999. 207 с.

Зайчук О. В., Крупчан О. Д., Ковальський В. С та ін. Сучасна правова енциклопедія. НДІ приватного права і підприємства НАПрН України. НДІ інтелектуальної власності НПрН України. Київ. Юрінком Інтер. 2015. 408 с.

${ }^{2}$ Корельський В., Перевалова В. Теория государства и права: учебник для вузов Москва: НОРМА-ИНФА. 2002. 549 с.

${ }^{3}$ Korelsky V., Perevalova V. Theory of state and law: a textbook for universities Moscow: NORMA-INFA. 2002. 549 p.
} 
significant deepening of the cooperation between law enforcement, judicial and other competent authorities and officials in the fight against crime. The geographical boundaries of international cooperation are constantly expanding, its scope and methods and forms are being improved. As a rule, when it comes to international cooperation in the field of investigating crimes of an international nature, this refers to international legal assistance, which is implemented on the basis of international treaties.

Cases where such legal assistance is provided without the conclusion of the relevant contracts are rarely and mainly related to decision making in a particular case at the level of the central executive body.

\section{Ways for a complete cooperation of Ukraine and the European Union in the law enforcement}

Legal aid treaties ensure the fullest exercise of national jurisdiction and the avoidance of conflicts of jurisdiction - for this very purpose, States conclude them.

Most of these treaties are bilateral in nature, but in some cases, subject to certain integration relations, legal aid is resolved on the basis of multilateral agreements. Ukraine is most actively involved in the legal aid system established within the CIS and the Council of Europe. In the first case, the main legal instrument is the 1993 Convention on Legal Assistance in Civil, Family and Criminal Matters ${ }^{4}$.

Legal co-operation within the Council of Europe is governed by a number of instruments, such as the Convention on Mutual Assistance in Criminal Matters (1959), the Convention on Extradition of Offenders (1957), the Convention on the Repatriation of Minors (1970), and the Convention on Transfer. criminal proceedings (1972) Convention on Legal Assistance and Legal Relations in Civil, Family and Criminal Matters, Convention on the Transfer of Sentenced Persons (1983) and others.

The general principles and directions of cooperation of law enforcement authorities of the EU Member States are laid down in Section VI of the "Regulation on cooperation in the field of justice and home affairs" of the Treaty on European Union. In particular, Art. 29 emphasizes that, without prejudice to the powers of the European Communities, the Union aims to provide citizens with a high level of security in the area of freedom, security and justice through joint action by Member States in the fields of police and judicial cooperation in criminal matters, the prevention of racism and xenophobia.

\footnotetext{
${ }^{4}$ Конвенція про правову допомогу і правові відносини у цивільних, сімейних і кримінальних справах від 22.01.1993.URL. http://zakon3.rada.gov.ua/ laws /show/ 997_009
} 
For example, the UN Convention against Corruption of 31 October 2003 provides for law enforcement cooperation aimed at detecting, suspending, detecting, investigating and preventing criminal offenses against corruption, such as: search and seizure and freezing of property; the detection, freezing and tracking of proceeds of crime defined in this Convention or of property the value of which corresponds to the value of such proceeds; property, equipment and other means used or intended to be used in the commission of the offenses established by this Convention; asset seizure; protection of witnesses, experts and victims; protection of persons reporting information; obtaining testimony from individuals or witnesses; service of court documents; overview of objects and places; provision of information, material evidence and expert opinions; providing originals or certified copies of relevant documents and materials, including government, banking, financial, corporate or commercial documents; detection and tracking of proceeds from criminal activity, property, means of committing crimes or other objects for the purpose of proving, promoting the voluntary appearance of relevant persons at the request of a State Party; providing information on its own initiative; providing any other assistance which does not contravene the law of the requesting State Party ${ }^{5}$.

The Law of Ukraine "On Ratification of the Council of Europe Convention on Laundering, Search, Seizure and Confiscation of Proceeds from Crime and on the Financing of Terrorism" of 17 November 2010 aims at preventing and counteracting the laundering of proceeds of crime, the basis of which is the Council of Europe Convention on the laundering, search, seizure and confiscation of proceeds of crime of 16 May $2005^{6}$.

This International Treaty establishes that each Party shall take such measures as may be necessary to enable it to seize the instruments and means of crime and proceeds or property the value of which corresponds to such proceeds, and to seize property, and to take measures to block, arrest and forfeiture: property into which income has been converted or converted; property obtained from lawful sources, if it was wholly or partially raisednot more than the estimated value of such income; profits or other benefits derived from proceeds, from property into which proceeds from crime have been converted or converted, or from property to which proceeds from crime have been attracted, up to the estimated value of such proceeds, in the same way and how much and how much it applies to revenue.

\footnotetext{
5 Конвенція Організації Об'єднаних Націй проти корупції від 31 жовтня 2003 року. Закон України від 18.10.2006 р. № 251-V. Відомості Верховної Ради Украӥни. 2006. № 50. $496 \mathrm{c}$.

6 Конвенція про відмивання, пошук, арешт та конфіскацію доходів, одержаних злочинним шляхом від 08.11.1990 p. URL. http:/ /zakon. nau.ua/ doc/?uid =1014.171.0
} 
Thus, international cooperation of law enforcement agencies is realized through the implementation of measures enshrined in international legal acts, insofar as they do not contravene the current legislation; the actions of the engagement participants must be coherent and purposeful; the main purpose of such cooperation is the indirect protection of human rights and freedoms through the effective, timely, comprehensive, complete and true prosecution; must be carried out in accordance with the applicable principles of international cooperation in the fight against crime.

Thus, the Decree of the President of Ukraine of June 27, 1999 No. 151 approved the list of central executive authorities responsible for carrying out the tasks defined by the Strategy for the Integration of Ukraine into the European Union. Thus, according to the above list, the Ministry of Internal Affairs of Ukraine is also part of the system of central executive authorities responsible for cooperation with the EU.

Law enforcement agencies, as the largest representatives of the executive branch, in the course of fulfilling their responsibilities for establishing cooperation between Ukraine and the EU, become direct participants in administrative and legal relations, where they can interact with each other or with the subordinate bodies of the executive branch of industry, and with other public authorities, local authorities, enterprises, institutions, organizations or individuals.

We also believe that one of the main factors in uniting the efforts of law enforcement agencies to accomplish tasks in the context of European integration processes should be to coordinate the interaction of existing law enforcement agencies. After all, coordination of law enforcement activities is one of the main management functions that unites and organizes the efforts of law enforcement agencies to achieve the overall socially desired goal.

The main components of law enforcement coordination include the following forms: joint meetings of colleges, operational meetings, exchange of information, introduction and use of unified databases, mutual use of training opportunities, development and implementation of special operations, issuance of methodological recommendations and other organizational and administrative documents.

By their nature, coordination should be an independent means of organizing management and should be used to ensure the coordination of the functioning of autonomous units of different law enforcement agencies with a common purpose. It would be advisable to develop coordination procedures in connection with the dynamics of coordination development in the performance of tasks and functions of law enforcement authorities, which will further determine the priority actions and content of tactical operations in documenting and investigating crimes. 
In the current context, a fundamental step towards bringing Ukraine closer to the European Union and establishing a new level of cooperation with it in the priority spheres of public life should be the introduction of significant refinements in the policy of systemic transformations in Ukraine, a significant strengthening of the social orientation of the state, increasing the effectiveness of the authorities constitutional issues in such a way that in Ukraine there is a democratic balance between the legislative and executive branches of power, the achievement in society of mutual understanding and harmony, improve current parliamentary cooperation between Ukraine and the EU.

Ukraine, EU institutions and EU member states have established various forms of mutually beneficial cooperation in the information field, such as: constant exchange of information and necessary documentation of the legislation in the field of communication; analysis of divergences of Ukrainian and EU communications legislation; development of normative documents for implementation of activities in the field of joint production of information media, planning and implementation of long-term scientific and technical research programs in the field of new information technologies, development and implementation of information and data security means; exchange of experts in order to create an effective information society in Ukraine and, as a consequence, to build a unified European information society; defining the strategy of mechanisms for active participation of Ukraine in the development of a unified European information society; information support of bodies of interstate cooperation; providing expert and technical assistance to Ukraine on the part of the EU in building an information society; standardization and unification of interstate electronic document circulation to the basic relevant international standards, etc.

It is proposed to reform the law enforcement system, in particular the service of police officers, whose main purpose is to adjust the tasks and functions of the law enforcement system, to introduce new principles of service, new criteria for evaluating the work of law enforcement agencies to enhance the protection of human rights and freedoms, as well as the interests of the public unlawful encroachment. At the same time, the reform identified the direction of ensuring a transparent system of competitive selection of persons for positions, created a new system of certification of law enforcement personnel, changed approaches to training employees of these bodies, which provided a change in their attitude to perform their duties in the direction of their awareness of giving state-sponsored services to ensure, first and foremost, the safety of each person, his or her personal and property rights, public and state interests. 
It is proposed to ensure that the rule of law is as transparent and friendly to society as possible. An important area is a thorough decentralization and implementation of effective mechanisms of public control over law enforcement. The principle of legality should be a priority in the work of such bodies: the system of issuing and executing orders should be such that a police officer is guided by law and does not carry out clearly criminal orders. At the same time, in the process of implementing the strategy, the Ministry of Internal Affairs of Ukraine was reformed into a governing body within the system of central executive bodies.

The next problem is communication itself, as a number of EU member states simply ignore requests from other countries. Therefore, representatives of national law enforcement agencies with representatives of foreign cultures should be given considerable attention by addressing the negative effects of culture clashes on interpersonal communication and group interaction.

The findings of cross-cultural psychologists suggest that the presence of certain differences and differences in the self-concept of representatives of collectivist and individualistic cultures causes different degrees of expression of the phenomenon of fundamental attribution error. Attribution should be understood as the conclusions that people make about the cause of events and about their own and others' behavior. Therefore, an attribution error is an incorrect (erroneous) interpretation of the behavior of other entities in terms of their internal state ${ }^{7}$.

Thus, in accordance with the Law of Ukraine "On Amendments to Certain Legislative Acts of Ukraine in connection with the Ratification of the Second Additional Protocol to the European Convention on Mutual Assistance in Criminal Matters", Article 85-3 of the Code of Criminal Procedure was set out as follows: "In case the participants of investigative or other procedural action cannot appear at the inquest body, investigator, prosecutor or court at the place of trial, as well as the need to ensure the safety of the persons involved in criminal proceedings, or for other justified reasons, the investigative or procedural their involvement can be done by a conference call or a video conference. A conference call or video conference is held on the instructions of the investigating authority, investigator, prosecutor or court. Videoconferencing can be used during the interrogation of a witness, expert, suspect, accused and defendant, eye rate, presentation for identification, playback of the situation and circumstances of the event. Investigative actions during a video conference with the participation of the suspect, accused and defendant shall be conducted only with their written consent, as indicated in the protocol of the investigative action.

7 Стратегія сталого розвитку “Україна-2020". Затверджена Указом Президента України від 12 січня 2015 р. № 5. 
A conference call may be used when interviewing a witness or expert with their written consent. During the conference or video conference, audio or video is recorded. The body of the inquiry, the investigator, the prosecutor or the court being prosecuted and the executing authority shall draw up separate protocols to which a conference or videoconference is required, to which the appropriate audio or video recording is obligatory.

It is also worth noting Article 18, paragraph 18, of the United Nations Convention against Transnational Organized Crime, which states that, to the extent possible, it complies with the fundamental principles of domestic law, if any person is within the territory of a State Party and should be heard as a witness or expert by the judicial authorities of another State Party, the first State Party may, at the request of another State Party, authorize a hearing by communication if the personal presence of the respondent Noah persons on the territory of the requesting State Party is not possible or desirable.

States Parties may agree that the hearing shall be conducted by the judicial authority of the requesting State Party in the presence of representatives of the judicial authority of the requested State Party ${ }^{8}$.

However, in practice, the use of telephone and video conferencing in normal use is hindered by their dependence on complex technical infrastructure.

At present, the European Union is still at the stage of its territorial and political formation, so it is only natural that it should focus its efforts first on preventing urgent threats. Therefore, priority areas for cooperation with Ukraine in the field of security are the fight against organized crime, international terrorism, money laundering, drug trafficking and illegal migration. Recently, administrative reform in Ukraine has been closely linked to the implementation of constitutional reform, the content of which is reformatting the balance of higher power structures, ie the redistribution of powers and responsibilities between the President, the Government and Parliament, minimizing the threat of power, establishing transparent transparency. coalitions.

In our view, the implementation of constitutional reform has somewhat complicated and slowed down the administrative reform process, as both the President and the Government and Parliament will not be able, for some time, to develop an effective decision-making mechanism and identify new opportunities for executive and local government., which can destabilize the political situation in Ukraine and discredit Ukraine's image in the international arena.

${ }^{8}$ Афанасіаді Д.М. Адміністративно-правові засади правоохоронних органів та інших органів при розслідуванні міжнародних злочинів. автореф. на здобут канд. юр. наук. 12.00.07. Дніпропетровськ. 2012. 22 с. 
We believe that there are disputes between the President, the Government and the Parliament due to the fact that these public authorities were not quite ready for such changes. In addition, agreeing with the view of former Foreign Minister A. Zlenko, it should be noted that a certain imbalance among the higher structures of state power is caused by the imperfection of the constitutional changes themselves, by the presence of different interpretations of the Constitution, which in some way leads to disputes between the above mentioned entities. and undermines the principles of their effective functioning

Administrative reform is central because it is related to the need to streamline the system of central executive bodies, increase their efficiency, strengthen the leading role of ministries as the main subjects of development and implementation of state policy, reform the local government system through municipal reform.

As the issues of integration of Ukraine into the European community are highlighted, the establishment of cooperation between Ukraine and the EU member states, one of the ways of solving which is the achievement of European standards and values in the field of state administration (in particular, reforming the system of executive bodies and local selfgovernment through the creation of public administration), it is in this area of reform that we must focus our attention. In addition, it should be noted that the need to study the peculiarities of the creation and functioning of public administration in Ukraine is due to the widespread use of this concept in EU countries, as well as the need to establish a new level of cooperation between Ukraine and the EU in modern conditions ${ }^{9}$.

V. Melnyk stated that the analysis of police activity of individual countries of the world gives grounds to claim that in European countries police activity is community oriented, that is, to establish close links with the population. Therefore, in many countries, programs have been put in place for police interaction with the public, including "Stop the Offender", "Safe Housing Patrol", "Community Patrol", Neighborhood Assistance", "Combined Selective Patrol", "Precinct Police Offices, Department Stores offenses", "Rural Crime Prevention Unit by Radio Stations", "Bicycle Patrol", "Senior Precinct Concept" and others ${ }^{10}$.

However, unfortunately in Ukraine today, the public does not actively participate in the proper provision of the process of adaptation of the

\footnotetext{
9 Конвенция Организации Объединенных Наций против транснациональной организованной преступности. URL: http://www.un.org/ru/documents/decl_conv/ conventions/orgcrime.shtml

10 Про внесення змін до Конституції України: Закон України від 8 грудня 2004 року // Відомості Верховної Ради України. 2005. № 2. С. 44.
} 
administrative legislation of Ukraine to EU norms and standards. We believe that this situation is caused by the fact that no real and effective mechanisms for involving the public (eg relevant non-governmental organizations, independent think tanks) in the adaptation process have been created yet; their consciousness.

Taking into account that the administrative-territorial units of Ukraine have land and sea borders with neighboring states, the activation of border cooperation in the aspect of cooperation of certain regions is of particular importance for our country. Its dynamic development is largely determined by the peculiarities of the current stage of international relations. Direct links between the border regions have become widespread on the European continent, making the existence of Europe of the Regions a reality.

In addition, at the border of Ukraine and Russia there is a need to create an optimal network of checkpoints and maximum approximation of their infrastructure and functioning mechanism to the requirements of the EU, which will create favorable conditions for cross-border cooperation, use of Ukraine's transit potential, accelerate socio-economic development of border regions. The arrangement of the border infrastructure is one of the elements of the implementation of the strategic course of Ukraine before EU membership. The incompleteness of the contractual legal registration of the state border of Ukraine is a threat to the national interests and security of Ukraine

The development of the state border infrastructure in Ukraine implies the realization of short and long term tasks: the border should maximally promote the legal movement of persons, goods and vehicles and at the same time meet all modern requirements in order to securely protect national and economic security. Therefore, it is important to create the conditions for increasing the efficiency of the national network of international transport corridors, the formation of an integrated system of border protection in Ukraine and the maritime economic zone, the development of regulatory framework of border activity, further optimization of the structure of the State Border Service of Ukraine ${ }^{11}$.

The main problem of the system of institutional support of European integration of Ukraine remains the lack of effective coordination in this field and insufficient staffing of the process of European integration (especially in the sphere of legislative approximation), since the established system of executive authorities has shown its inefficiency and requires significant improvement. Therefore, it is necessary to decide on the creation of a single

${ }^{11}$ Мосенцева Т. Конституційна реформа: внутрішні та зовнішні чинники (інтерв’ю 3 екс-міністром закордонним справ А. Зленком) // День. № 36.28 лютого 2007 року. 
coordinating body within the system of bodies of the executive power of Ukraine, which would formulate a strategy of relations between Ukraine and the EU and would be responsible for its effective implementation.

It is also advisable to analyze and review the functional responsibilities and activities of the structural units of central executive bodies responsible for implementing European integration policies. The competence of the Parliamentary Committee on European Integration and the Main Legal Department of the Verkhovna Rada in the area of legislative approximation is needed in order to increase Parliament's ability to exercise proper control over these activities. In addition, it is necessary to anticipate and consolidate at the legislative level the mechanism of accountability of public authorities of Ukraine (officials) in the field of establishing effective cooperation between Ukraine and the EU in priority areas for the improper execution by a particular public authority of its powers (or their excess) in the sphere of cooperation. Therefore, the improvement of legislation in the field of cooperation between law enforcement agencies of Ukraine and the EU should be achieved through the consolidation at the legislative level of the strategy "community rolicing", numerous changes and additions to the by-laws, the establishment of closer cooperation between police and urban.

Thus, in view of all the above, we believe that the need to reform public administration in Ukraine by bringing the activities of executive bodies and local self-government in line with the standards and principles of activity of public administrations in European countries by creating an effective and relatively stable system of executive bodies, the division of powers between executive power on the ground and local self-government bodies, ensuring the implementation of delegated powers, introduction of a rational and transparent procedure for public policy-making with the involvement of the public, development and implementation of effective legal mechanisms for protecting citizens in relations with public administration bodies is one of the prerequisites for Ukraine to become a full member of the EU, to which all state bodies should be directed. authorities in Ukraine.

Of particular importance is the large-scale outreach work, including the development and implementation of a national program to inform the public about the situation in the EU, the problems and gains of Ukraine on the path of European integration. The media also need orientation on coverage of the development of relations between Ukraine and the EU, a broad and comprehensive explanation of the importance of Ukraine's European choice, ensuring impartial perception of European integration by citizens, regular information on political, economic and social processes taking place in EU countries. achievements through the joint resolution of individual issues. 
The need to improve the legal framework for the organization and operation of law enforcement agencies and to reform the existing system on this basis is conditioned by the course of building a social, legal and democratic state and civil society and Ukraine's acceptance of a number of international legal commitments in the field of human and citizen's rights. The proper functioning and development of the international law enforcement sector is largely determined by the quality level of activity of the entities.

In the context of social transformation of modern Ukraine, the question of forming a fully-fledged European-type rule of law is particularly acute. It should be noted that the nation as a whole and its legitimate authorities and public administration have determined the historical perspective of the development of Ukrainian society, which has been embodied in an officially proclaimed course for integration into Europe and its structures, the implementation of which provides for bringing the norms and standards of our internal life. society in accordance with the norms and standards of Europe.

A special issue for Ukraine now is to preserve its territorial integrity. The control and coordination of cooperation at the EU external border is carried out by the European Agency for the Management of Operational Cooperation at the EU's External Borders, FRONTEX. On June 11, 2007 in Luxembourg, during the meeting of Ministers of Justice and Home Affairs in Ukraine-EU Troika format, the Working Agreement on Establishing Operational Cooperation between the STS of Ukraine and FRONTEX was signed(European Agency for the Management of Operational Cooperation at the External Borders of the Member States of the European Union, pursuant to Council Regulation (EC) No 2007/2004 of 26.10.2004, contributes to enhancing border security by ensuring the coordination of the activities of Member States in the implementation of Community actions concerning the management of external borders).

This arrangement obliges the Border Agency of Ukraine to the following activities: counteracting uncontrolled migration and other illegal activities at the border, enhancing border security between EU Member States and Ukraine, developing good relations and mutual trust between border authorities between border agencies at the border EU and Ukraine. An important area of cooperation between Ukraine and the EU in the area of border and customs issues is the activity of the European Commission Mission for Border Assistance to Ukraine and the Republic of Moldova (hereinafter - EUBAM Mission).

On October 7, 2005, a Memorandum of Understanding was signed between the Government of Ukraine, the Government of the Republic of 
Moldova and the European Commission on a European Border Assistance Mission to Ukraine and the Republic of Moldova (EUBAM), which created the legal framework for practical cooperation between Ukraine and the EU. on customs and border issues ${ }^{12}$.

Based on the Decree of the Cabinet of Ministers of Ukraine No. 57-r of 13.04.2007 "On approval of the draft Agreement (in the form of an exchange of notes) between the Government of Ukraine, the Government of the Republic of Moldova and the European Commission on the extension of the mandate of the European Commission Border Assistance Mission in Ukraine and the Republic of Moldova "has been extended the mission until December 1, 2009. This Mission is an advisory and technical body.

The Mission's practice includes conducting joint operations with law enforcement, customs and border services of Ukraine and the Republic of Moldova. The purpose of the operations is to improve cooperation between the border and customs authorities of the two countries, to increase the effectiveness of operational interaction between border, customs and law enforcement services, to strengthen the fight against negative phenomena at the border.

Coordination meetings are held each month with the participation of representatives of foreign policy agencies, border and customs services, ministries of internal affairs, justice and security services of Ukraine and the Republic of Moldova. The EUBAM Mission Advisory Board meets quarterly on a regular basis ${ }^{13}$.

The Mission's main tasks are: to work with Ukraine and Moldova to harmonize border management standards and procedures with those in force in the EU; promote the professionalism of Ukrainian and Moldovan customs and border services at the operational level; develop risk analysis systems; to improve cooperation and complementarity between border and customs services and other law enforcement agencies; support cross-border cooperation.

The Mission provides field training and advice to Ukrainian and Moldovan officials to enhance the capacity of their services to carry out effective border and customs control and border surveillance.

12 Білозерська Т.О. Адміністративно-правові засади співробіництва України та Європейського Союзу у сучасних умовах : автореф. на здобут. канд. юр наук. 12.00.07. 2009. 22 c.

${ }^{13}$ Мельник В.І. Впровадження "community policing” у діяльність дільничних офіцерів поліції під час охорони публічного порядку в сільській місцевості. URL: http://dspace.onua.edu.ua/bitstream /handle/11300/9648/Мельник\%20B.I.\%20\%20Впровадження\% 20community\%20policing.pdf. 
Yes, HUREMAS (Human Resources Management) is a project implemented by the International Organization for Migration with the support of partners from EU Member States and funded by the European Commission and the US Department of State. The project partners work closely with the STS of Ukraine to reform and improve the procedures for recruiting, training and career advancement of STS personnel, as well as providing the necessary technical assistance and equipment to the Service, improving the legal framework in the field of state border protection, in order to strengthen Ukraine's ability to solve problems. border security. This project is being implemented to support the efforts of the Government of Ukraine to accede to EU and Schengen standards, which involves the transformation of the MRF into a civil law enforcement structure ${ }^{14}$.

The Ukrainian Border Agency works under the conditions of constant control by the EU.

Ukraine also cooperates with European countries with no borders, such as France. Thus, on December 12, 2005 the Protocol on Cooperation between the Administration of the State Border Guard Service of Ukraine and the Central Border Police Office of the French Republic was signed. The Parties agreed to provide assistance in order to effectively combat illegal migration by exchanging information in the following areas: 1) flows of illegal migration at their national borders; 2) nationality of illegal migrants; 3) channels of illegal migration; 4) the methods and methods used to organize the channels of illegal migration; 5) ways of forgery of documents and their acquisition; 6) new regulatory acts on border issues and combating illegal migration; 7) introduction of modern technologies of state border protection, counteraction to illegal migration and falsification of documents; 8) training of staff and implementation of cooperation by mutual agreement of the Parties.

Border cooperation of Ukraine with the neighboring countries and the EU provides not only the regulation of the issues of effective use of borders, but also the functioning of the European Border Agency with the powers that will allow the effective exercise of the existing powers to this body. In most European countries, the issue of law enforcement activities in the border services has been resolved through the entry into the Ministry of the Interior of these services and the full or limited extension of the rights and powers of national police to their staff. Improving the effectiveness of border protection can be achieved by accelerating the process of demarcation of the state border.

14 Катеринчук І.П. Правові та організаційні засади співробітництва України та Європейського Союзу в правоохоронній сфері. Автореф.на здобут. канд. юр. наук. 12.00.07. Ірпінь. 2009. 22 с. 
One of the priorities for cooperation, which needs to be addressed as a matter of priority, is the EU's Joint Strategy for Ukraine identifying justice and home affairs, in particular ensuring the security of Ukraine's borders and deterring illegal migration through Ukraine to the $\mathrm{EU}^{15}$.

The process of European integration is a powerful impetus for institutional change in the field of migration policy. For candidate countries, this is one of the EU's requirements for membership. Given the above, we can conclude that a major step towards EU-Ukraine cooperation should be to concentrate efforts on gaining EU member status. The European legal area is the result of the interaction of the legal systems of European states with regional norms of international law and norms created through the legal activities of European organizations (EU law, Council of Europe, OSCE / OSCE). After all, international cooperation of law enforcement agencies is implemented through the implementation of measures enshrined in international legal acts, insofar as they do not contravene the current legislation; the actions of the engagement participants must be coherent and purposeful; the main purpose of such cooperation is the indirect protection of human rights and freedoms through the effective, timely, comprehensive, complete and true prosecution; must be carried out in accordance with the applicable principles of international cooperation in the fight against crime.

And the need to reform public administration in Ukraine by aligning the activities of the executive and local self-government bodies with the standards and principles of the public administrations of European countries by creating an effective and relatively stable system of executive bodies, delimiting the powers between local and local governments, ensuring the fulfillment of delegated powers, the introduction of a rational and transparent public policy-making procedure, the development and implementation of effective legal mechanisms for protecting citizens in relations with public administration bodies is one of the prerequisites for Ukraine to become a fully-fledged EU member state. directed efforts of all public authorities in Ukraine.

And there is an important role in this process of conducting large-scale outreach work, in particular the development and implementation of a national program to inform the public about the situation in the EU, the problems and gains of Ukraine on the path of European integration. The media also need orientation on coverage of the development of relations

15 Меморандум про взаєморозуміння між Урядом України, Урядом Республіки Молдова та Європейською Комісією щодо місії Європейської Комісії з надання допомоги в питаннях кордону в Україні та Республіці Молдова від 07.10.2005 р. ОВУ. 2006. № 16. Ст. 1248. 
between Ukraine and the EU, a broad and comprehensive explanation of the importance of Ukraine's European choice, ensuring impartial perception of European integration by citizens, regular information on political, economic and social processes taking place in EU countries. achievements through the joint resolution of individual issues ${ }^{16}$.

\section{CONCLUSIONS}

We believe that the need to reform public administration in Ukraine by aligning the activities of executive bodies and local self-government with the standards and principles of public administrations in European countries by creating an effective and relatively stable system of executive bodies, and the division of powers between local and regional authorities local selfgovernment, ensuring the implementation of delegated powers, introduction of a rational and transparent procedure for public policy-making with the involvement of the public, development and implementation of effective legal mechanisms for protecting citizens in relations with public administration bodies is one of the prerequisites for Ukraine to become a full member of the EU, to which all state bodies should be directed. authorities in Ukraine.

Of particular importance is the large-scale outreach work, including the development and implementation of a national program to inform the public about the situation in the EU, the problems and gains of Ukraine on the path of European integration. The media also need orientation on coverage of the development of relations between Ukraine and the EU, a broad and comprehensive explanation of the importance of Ukraine's European choice, ensuring impartial perception of European integration by citizens, regular information on political, economic and social processes taking place in EU countries. achievements through the joint resolution of individual issues.

In order to improve cooperation between Ukraine and the EU, a number of laws are needed to improve migration policy, counter-terrorism and crime.

\section{SUMMARY}

In connection with Ukraine's determination of a strategic goal integration into the European Union, including membership in this international association - it is an important task to bring national legislation in line with Community law, which causes reform of the legal system of the country as a whole. The path to European integration involves the real

${ }^{16}$ Спільна стратегія Свропейського Союзу щодо України, схвалена Свропейською Радою від 11.12.1999 p. URL: http://zakon1.rada.gov.ua/cgi-bin/laws/main.cgi?nreg=994_492 
protection and protection of fundamental human rights and freedoms, the creation of a rule of law, social and democratic state that will have a worthy place in the world community. The purpose of the article is to study the theoretical and legal foundations of Ukraine's EU integration process in the law enforcement field. Because of the experience of foreign experience, Ukraine is simply obliged to use it. Because today, foreign countries have accumulated considerable experience in joint activities to solve crimes of an international nature and combating international crime. Ukraine has announced its intention to integrate into the European Community, so it is quite relevant to adapt the national legislation to the European Union. The National Police of Ukraine is now in the process of global reform. The successful reform of law enforcement agencies depends on the completion of the reform of almost all strategic areas in Ukraine. Completing the reforms is a global task for every Ukrainian on the path to a better life.

\section{REFERENCES}

1. Свропейський Союз: Консолідовані договори. Київ. Port-Royal, 1999. $207 \mathrm{c}$.

2. Зайчук О. В., Крупчан О. Д., Ковальський В. С та ін. Сучасна правова енциклопедія. НДІ приватного права і підприємства НАПрН України. НДІ інтелектуальної власності НПрН України. Київ. Юрінком Iнтер. 2015. $408 \mathrm{c.}$

3. Корельський В., Перевалова В. Теория государства и права: учебник для вузов Москва: НОРМА-ИНФА. 2002. 549 с.

4. Конвенція про правову допомогу i правові відносини у цивільних, сімейних і кримінальних справах від 22.01.1993. URL: http://zakon3.rada.gov.ua/ laws /show/ 997_009 (дата звернення 15.11.2019)

5. Конвенція Організації Об'єднаних Націй проти корупції від 31 жовтня 2003 року. Закон України від 18.10.2006 p. № 251-V. Відомості Верховної Ради України. 2006. № 50.496 с.

6. Конвенція про відмивання, пошук, арешт та конфіскацію доходів, одержаних злочинним шляхом від 08.11.1990 p. URL: http://zakon.nau.ua/doc/?uid=1014.171.0 (дата звернення 15.11.2019)

7. Стратегія сталого розвитку “Україна-2020". Затверджена Указом Президента України від 12 січня 2015 р. № 5.

8. Афанасіаді Д. М. Адміністративно-правові засади правоохоронних органів та інших органів при розслідуванні міжнародних злочинів. автореф.на здобут канд. юр. наук. 12.00.07. Дніпропетровськ. 2012. $22 \mathrm{c}$. 
9. Конвенция Организации Объединенных Наций против транснациональной организованной преступности. URL: http://www.un.org/ $\mathrm{ru} /$ documents/decl_conv/conventions/orgcrime.shtml (дата звернення 15.11.2019)

10. Про внесення змін до Конституції України : Закон України від 8 грудня 2004 року // Відомості Верховної Ради України. 2005. № 2. C. 44.

11. Мосенцева Т. Конституційна реформа: внутрішні та зовнішні чинники (інтерв'ю з екс-міністром закордонним справ А. Зленком) // День. № 36. 28 лютого 2007 року.

12. Білозерська Т. О. Адміністративно-правові засади співробітництва України та Свропейського Союзу у сучасних умовах. автореф. на здобут. канд. юр. наук.12.00.07.2009. 22 с.

13. Мельник В.I. Впровадження "community policing” у діяльність дільничних офіцерів поліції під час охорони публічного порядку в сільській місцевості. URL: http://dspace.onua.edu.ua/bitstream/handle/ 11300/9648/Мельник\%20B.I.\%20\%20Впровадження\%20community\% 20policing.pdf (дата звернення 15.11.2019)

14. Катеринчук І.П. Правові та організаційні засади співробітництва України та Свропейського Союзу в правоохоронній сфері. Автореф. на здобут. канд. юр. наук. 12.00.07. Ірпінь. 2009. 22 с.

15. Меморандум про взаєморозуміння між Урядом України, Урядом Республіки Молдова та Європейською Комісією щодо місії Європейської Комісії з надання допомоги в питаннях кордону в Україні та Республіці Молдова від 07.10.2005 р. ОВУ. 2006. № 16. Ст. 1248.

16. Щодо місії ЄК з надання допомоги у питаннях кордону України та Республіці Молдова. Офіційний веб-сайт Міністерства закордонних справ України. URL: http://www.mfa.gov.ua/mfa/en/publication/ content/19993.htm (дата звернення 15.11.2019)

17. Спільна стратегія Свропейського Союзу щодо України, схвалена Європейською Радою від 11.12.1999 p. URL: http://zakon1.rada.gov.ua/ cgi-bin/ laws/ main. cgi? nreg=994_492 (дата звернення 15.11.2019).

\section{Information about the author:} Bondar V. V.,

Head of Department of Administrative Law and Administrative Process, Kherson Faculty of the Odessa State University of Internal Affairs 1, Fonvizina str., Kherson, 73000, Ukraine 


\section{FREEDOM OF CITIZENS IN THE CONDITIONS OF MILITARY SERVICE}

\section{Chebotareva G. V.}

\section{INTRODUCTION}

In the process of building the rule of law in Ukraine, perhaps the most important place is occupied by the solution of the problem of realization and protection of human and civil rights and freedoms. There is a reformation of all state institutions, bringing them into line with the provisions of the Basic Law.

In the context of reforming the Armed Forces, compliance with the legislation on universal military duty, military service and the legal status of servicemen, their social and legal protection, becomes important. The Constitution of Ukraine defines the fundamental principles in the field of human and civil rights and freedoms. "Human rights and freedoms and their guarantees, as stated in article 3 of the Basic Law, determine the content and direction of the state. The state is responsible to the person for its activities. The affirmation and enforcement of human rights and freedoms is the primary responsibility of the state." Therefore, the legal basis for military service must fully ensure the implementation of the rights and freedoms of the individual and citizen by military personnel. The serviceman should be perceived not only as a subject, but as an object of national security. Illegal and unlawful restriction of his rights and freedoms is inadmissible ${ }^{1}$.

A soldier should be perceived primarily as a citizen in uniform. After the perception and, accordingly, the disclosure of this topic is possible subject to a deep understanding and awareness by the servicemen themselves and the public of the essence of ensuring, implementing and protecting human rights and freedoms in the conditions of military service, the peculiarities of the legal status of servicemen, the legitimacy of establishing certain restrictions for them.

This section is not intended to disclose the content of all human and civil rights and freedoms in military service. It should be noted that the absolute majority of them, taking into account the Constitution and laws of Ukraine, fully applies to military personnel as equal members of civil society. At the same time, awareness of the principles and structure of the legal status of

\footnotetext{
${ }^{1}$ About economic activity in Armed Forces of Ukraine: the Law of Ukraine of 21.09.1999 No. 1076-XIV. URL: http://zakon1.rada.gov.ua/laws/show/1076-14
} 
servicemen, which is based on rights, freedoms and obligations, will allow the reader to correctly interpret any legal norm that defines rights and obligations, and apply it in solving a specific life situation.

\section{The concept and legal basis of the legal status of military personnel in Ukraine}

The relations that arise between the state and the individual, the relationship between people are fixed by the state in a legal form - in the form of rights, freedoms and obligations, which in their totality represent the legal status of a person and a citizen.

The legal status of a person and a citizen can be characterized as a system of rights and obligations, which are enshrined in the Constitution and other legislative acts.

Rights and obligations are the original element of law. They not only fix certain standards of behavior that the state considers mandatory, useful, appropriate for the normal functioning of the social system, but also reveal the basic principles of relations between the state and the individual.

Legal status, the nature of rights and obligations as the key concepts of legal science are constantly in the spotlight of scientists. There are several approaches to determining the legal status of an individual. Some of them equate the notion "legal status of a person" and "legal status persons" include legal status such as citizenship, the General legal principles of the legal status, rights, freedoms and duties, guarantees of rights and freedoms, the corresponding legal provisions. According to another view, the concept of legal status should be limited to categories of rights and obligations, which makes it possible to define its structure more clearly.

Thus, we will talk about two concepts: the legal status (position) of the person and the legal status of the person (soldier).

\section{Characteristics of the main elements of the legal status of a person}

The distinction between the concepts of "legal status" and "legal status of a person" is certainly relative, but at the same time, in our opinion, convenient for disclosure and awareness of the topic. The main elements characterizing the legal status of a person as a whole may include citizenship, legal personality, legal responsibility, principles of legal status, legal interests of a person, directly legal norms that determine the legal status of a person. It is advisable to refer to a brief description of the main of these elements.

Citizenship is a special political and legal relationship between a person and the state, which gives a person a special status, which implies legal recognition of the state affiliation of a person both in the country and abroad 
and gives him a full range of rights and obligations enshrined in the legislation of the state.

From the definition it is obvious that citizenship is one of the determining prerequisites of the legal status of a person, indicates the difference between the concepts of the legal status of a person and the legal status of a citizen. For the first time, the distinction between these concepts at the legislative level was recorded in the French Declaration of human and civil rights in 1789. It should be noted that the scope of the rights and obligations of a citizen is large, compared with the rights and obligations of a person. In particular, we note that the universal military duty in Ukraine applies only to its citizens ${ }^{2}$.

But according to the Constitution in our state there is a single citizenship. Therefore, there are no difficulties with the spread of universal military duty of its citizens, the passage of military service. However, a certain number of States recognize "dual citizenship". Naturally, under such conditions, it becomes more difficult to resolve the issue of military service by persons with dual citizenship. It is also obvious that the solution of this issue goes beyond the national legislation. In such cases, the provisions of the European Convention "on the reduction of cases of multi-citizenship and military duty" (1963) apply. In international practice, the doctrine of "real" (or effective) communication is widely applied, according to which a person with dual citizenship performs military service in the state in whose territory she predominantly resides.

\section{Legal personality includes the concept of legal capacity and capacity}

Legal capacity is the ability of a person to have rights and bear legal obligations (comes from the moment of birth of a person).

Legal capacity is the ability of a person to perform legally significant actions, that is, through them (actions) to acquire and exercise rights, create obligations for themselves and perform them (full legal capacity comes from the moment a person reaches adulthood).

It is necessary to point out the difference between the concept of legal personality in the branches of public and private law. In the branches of private law (civil, family, labor) there is a fundamental legal equality of all subjects regardless of their status ${ }^{3}$.

${ }^{2}$ About the state guarantees of social protection of the military personnel who leave service in connection with reforming of Armed Forces of Ukraine, and members of their families: the Law of Ukraine of 15.06.2004 No. 1763-IV). URL: http://zakon2.rada.gov.ua/ laws/show/1763-15

${ }^{3}$ The criminal code of Ukraine of 05.04.2001 № 2341-III. URL: http://zakon2.rada.gov.ua/ laws/show/2341-14 
In the branches of public law (criminal, administrative, military), there is mainly legal subordination and subordination, that is, issues of competence of state bodies and officials, on the one hand, and on the other - the question of passive legal personality of subordinates and subordinates, their duties and responsibilities, which are derived from the acts of authorities and officials.

Thus, legal personality is one of the significant, mandatory elements of the legal status of a person and a necessary prerequisite for its legal status.

Legal responsibility - the imposition on a person by the authorized bodies of state power, officials of the duties to bear adverse consequences of personal, organizational or material nature in the case of an offense, the performance or improper performance of the relevant duties.

Legal interests of the person - certain benefits of material and nonmaterial nature, which are enshrined not only in specific legal regulations, but also in General principles of law.

In other words, the interest is not always fixed in the rights of the person. As a rule, it precedes rights and obligations regardless of whether it is enshrined in law or simply subject to legal protection by the state.

The rights and obligations of the person have the corresponding normative fixing. This is what determines their legitimacy, the legitimacy of belonging to individual subjects. Therefore, it is reasonable to refer the relevant legal norms to the concept of the legal status of a person.

The principles of legal status are the fundamental ideas enshrined in the Constitution and other laws, the principles by which the rights, freedoms and duties of a person and a citizen are defined, as well as the guarantees of their implementation, and which transform the totality of individual rights and freedoms into a system.

Understanding of the legal nature of the principles of the legal status of a person is very important especially given the current provision of the Constitution of Ukraine on the rule of law (article 8 of the Constitution), the ability to apply the principle of analogy of law and the principle of analogy of law if there are gaps in the current legislation.

The basic principles of the legal status of a person include:

- Consolidation in national law of the rights and freedoms established by norms of international law.

- The principle of non-alienability and inviolability of the basic natural rights and freedoms of man and their belonging to him from birth (article 21 of the Constitution of Ukraine).

- The principle of equal rights and freedoms of persons (article 24 of the Constitution of Ukraine). This principle means that the exercise of human, civil rights, and freedoms must not violate the rights and freedoms of 
others. It proclaims the equality of all before the law and the court (part 3 of article 8 of the Constitution of Ukraine). The rights and freedoms of a person and a citizen are determined in the same way, regardless of sex, race, nationality, language, origin, place of residence, attitude to religion, etc. (part 3 of article 24 of the Constitution of Ukraine).

- The principle of unity of rights and duties of man and citizen (article 23 of the Constitution) is that there should not be rights without duties, as there should be no duties without rights. It is only in the process of fulfilling obligations that the rights that correspond to them are realized. In turn, the exercise of rights gives rise to certain obligations.

- The principle of guaranteeing human and civil rights and freedoms is that, firstly, constitutional rights and freedoms are guaranteed by the state and cannot be abolished, and, secondly, when new laws are adopted or amended, the content and scope of existing rights and freedoms cannot be narrowed.

- Guarantees of human, civil rights, and freedoms are a system of norms, principles, conditions and requirements that ensure the aggregate observance of the rights and freedoms of the legitimate interests of a person. This principle is one of the defining ones in the sphere of ensuring the realization and protection of rights and freedoms, and therefore requires a more complete disclosure of its content through the system of existing guarantees of rights and freedoms.

The system of guarantees of human rights and freedoms includes prerequisites of economic, political, organizational and legal nature, as well as protection of rights and freedoms. The system of guarantees is the conditions, means and methods ensuring the actual realization and comprehensive protection of the rights and freedoms of the individual ${ }^{4}$.

The practical realization of constitutional rights and freedoms is ensured by two criteria of guarantees. These are, first of all, General guarantees, which cover the whole set of objective and subjective factors aimed at the practical implementation of the rights and freedoms of citizens, the elimination of possible causes and obstacles to their incomplete or improper implementation, the protection of rights from violations. Secondly, these are special (legal) guarantees - legal bases and ways by means of which the rights and freedoms of citizens are realized, protected, protected, violations of the rights and freedoms are eliminated, the violated rights are restored.

General guarantees of rights and freedoms can be classified into economic, political and organizational.

\footnotetext{
${ }^{4}$ On international treaties of Ukraine: Law of Ukraine of 29.06.2004 No. 1906-IV). URL: http://zakon1.rada.gov.ua/laws/show/1906-15
} 
Economic guarantees of constitutional rights and freedoms of citizens of Ukraine are: the mode of production; the economic system of society, which should ensure the steady growth of productive forces on the basis of recognition and protection of various forms of ownership of the means of production; socially-oriented market economy; economic freedom of citizens and their associations in the choice of forms.

Political guarantees include: the state-the main organizer of the implementation and protection of human rights; the power of the people, which it exercises directly and through public authorities and local selfgovernment bodies; the right of citizens to freedom of Association in political parties and public organizations for the exercise and protection of their rights and freedoms; the right of citizens to participate in the management of state Affairs, in referendums, freely elect and be elected to public authorities and local self-government bodies; the right of citizens to apply for protection of their rights to the Commissioner of the Verkhovna Rada of Ukraine for human rights.

Organizational guarantees are systematic organizational activities of the state and all its bodies, officials and public organizations to create favorable conditions for the real enjoyment of their rights and freedoms.

Legal guarantees are the provision by the state of formal (legal) General obligation to those conditions that are necessary for everyone to be able to exercise their constitutional rights and freedoms. Legal guarantees are established by the state in the Constitution, norms of the current legislation. Their purpose is to provide real legal means of maximum implementation, protection and protection of constitutional rights and freedoms of citizens. In particular, the Basic Law provides for a number of specific guarantees, which are mainly traditional for the Constitution and laws of Ukraine. These include:

- the right to appeal in court the decisions, actions or omission of bodies of state power, bodies of local self-government, officials and officers;

- the right to compensation at the expense of the state or local selfgovernment bodies for material damage caused by illegal decisions, actions or omissions of these bodies and persons;

- the right to know their rights and obligations; laws and other regulatory legal acts that determine the rights and obligations of citizens, but are not brought to the attention of the population in the manner prescribed by laws, are invalid (article 57); inadmissibility of reverse action of the law is guaranteed ( no one can be responsible for acts that at the time of their);

- the right to legal assistance, which means, inter alia, that everyone is free to choose a defender of his rights, and in cases provided for by law, this assistance is provided free of charge (art. 59); 
- the principle of non-compliance with an obviously criminal order or order (art. 60);

- the principle of presumption of innocence, which means, inter alia, that a person is presumed innocent of a crime and cannot be subject to criminal punishment until his guilt has been proved legally and established by a court conviction, and that no one is obliged to prove his innocence of a crime (art. 62);

- the guarantee of inadmissibility of restriction of constitutional rights and freedoms means that these rights and freedoms cannot be limited, except for the cases provided by the Constitution of Ukraine (article 64).

The purpose of these and other legal guarantees contained in the Constitution and laws of Ukraine is to ensure favorable circumstances in which the status of a person and a citizen enshrined in the Constitution of Ukraine would become the legal and actual social status of each person. Guarantees, thus, are the link that allows for the necessary transition in the legal status of citizens from the possibility provided for in the Constitution and laws of Ukraine to reality.

\section{Normative regulation of the legal status of servicemen. Types of rights and obligations}

Given the above, we will also distinguish between the legal statuses of the individual servicemen in Ukraine in General and in particular its legal status, exclusively as a system of rights, freedoms and duties. In accordance with the legislation of Ukraine (the Law of Ukraine "on legal and social protection of servicemen and members of their families", the Statute of the internal service of the armed forces of Ukraine), servicemen are endowed with the full rights and freedoms and duties of citizens of Ukraine, cannot be limited in rights, except for cases expressly provided by law. At the same time, in the conditions of military service, citizens enter into special legal relations, they are assigned additional duties, and they are endowed with appropriate rights 5 .

To date, there are certain difficulties in the regulatory regulation of the rights, freedoms and duties of military personnel, there is no separate legal act, where they would be presented in a consolidated form. It is offered to Orient in a number of the relevant normative legal acts by means of the following conditional classification of the rights, freedoms and duties of the military personnel.

\footnotetext{
${ }^{5}$ About social and legal protection of the military personnel and members of their families: the Law of Ukraine of 20.12.1991 No. 2011-XII P. URL: http://zakon4.rada.gov.ua/ laws/show/2011-12
} 
First, these are General rights and obligations, which in turn are divided into civil, political, personal, socio-economic, cultural (they are disclosed in the previous sections). These rights and obligations are disclosed in international documents, agreements (international bill of human rights, European Convention for the protection of human rights and fundamental freedoms), the Constitution and laws of Ukraine.

Secondly, these are special rights and obligations.

They are most fully set out in the military statutes of the Armed Forces of Ukraine and some other legislative acts (for example, the Law of Ukraine "on General military duty and conscription"). It should be noted that in the Law of Ukraine "On universal military duty and military service" military service is defined as the state service of special nature and all the time the person in military service shall count towards the length of service.

And finally, third, these are special rights and obligations.

These may include certain restrictions that in accordance with the Constitution of Ukraine and the laws of Ukraine may be established in relation to the military, as well as benefits that must be considered as a kind of compensation for the restriction.

With regard to the legal regulation of this type of rights and obligations, it is necessary to note first the laws of Ukraine "on the Armed Forces of Ukraine", "on social and legal protection of servicemen and members of their families".

Thus, under the legal status of the soldier should understand the system of the rights and freedoms of man and citizen enshrined in the Constitution and other legislation, as well as special rights and obligations that arise in connection with military service.

The principle of combining the rights and freedoms and duties of a person, a citizen and a military person in the person of a serviceman is fundamental for determining his legal status, fully corresponds to the constitutional and legal bases for ensuring human rights and freedoms and in our opinion should be put at the center of all reform reforms in the sphere of military construction.

\section{Features of the legal status of military personnel}

The fundamental principle of the legal status of the serviceman is the inviolability of his status as a person and a citizen. "No one has the right to restrict military personnel in the rights and freedoms defined by the legislation of Ukraine", - stated in article 2 of the Law of Ukraine" on social and legal protection of military personnel and members of their families". Article 18 of the Charter of the internal service of the Armed Forces of 
Ukraine notes that "servicemen are protected by the state and have full rights and freedoms enshrined in the Constitution of Ukraine".

Regarding the legal status of servicemen, the provisions of article 22 of the Constitution of Ukraine apply: "the Rights and freedoms of man and citizen enshrined in this Constitution are not exhaustive. Constitutional rights and freedoms are guaranteed and cannot be revoked. When adopting new laws or amending existing laws, the content and scope of existing rights and freedoms shall not be restricted."

In our opinion, the modern legislative practice of the state is not quite consistent. Thus, the suspension of the legislation of Ukraine in terms of the benefits provided for the military by the laws of Ukraine on the state budget for 2000 (article 62) and for 2001 (article 58) comes into conflict with article 22 of the Constitution of Ukraine and therefore requires a minimum of official interpretation of this article of the Constitution and laws on the state budget in the necessary part.

We proceed from the fact (it was mentioned above) that part of the legal status of a serviceman is his special rights and obligations arising in connection with the passage of military service ${ }^{6}$.

Article 9 of the Charter of the internal service of the Armed Forces of Ukraine contains the following provision "Servicemen of the Armed Forces of Ukraine shall enjoy the rights and freedoms of citizens of Ukraine, taking into account the peculiarities determined by the Constitution of Ukraine, laws of Ukraine on military issues, military statutes of the Armed Forces of Ukraine and other legal acts".

The acts of legislation, military statutes, advisers, etc. define the special duties of the military. Comparing the relevant aspects of the legislation of the USSR and modern legal acts of Ukraine, we can conclude that a certain step forward is in terms of ensuring basic human rights and freedoms in military service. Thus, in the Charter of the internal service of the armed Forces of the USSR, the duties of servicemen included the following: "nothing, not even the threat of death, can force a soldier to surrender". In other words, the natural right of man to life was not recognized. Nothing of the kind is contained in the military statutes of the Armed Forces of Ukraine. Moreover, «the soldier is obliged to know and steadily observe the norms of international humanitarian law accepted by Ukraine". (article 15 of the Charter of the internal service of the Armed Forces of Ukraine). In accordance with international humanitarian law, prisoners of war are protected as victims of armed conflict and are subject to the relevant

\footnotetext{
${ }^{6}$ About Military service of a law and order in Armed Forces of Ukraine: the Law of Ukraine of 07.03.2002 No. 3099-III. URL: http://zakon4.rada.gov.ua/laws/show/3099-14
} 
provisions of the Geneva conventions for the protection of victims of war of 1949 and the two Additional protocols thereto of 1977. It can be concluded that servicemen of the Armed Forces of Ukraine, although this is not explicitly stated in the regulations, have the right to be captured. And this is a kind of form (carrier) of realization (provision) of the inalienable human right to life.

The peculiarity of the legal status of a serviceman is the establishment of certain restrictions in the rights and freedoms, the peculiarity of the implementation of certain rights and freedoms ${ }^{7}$.

In accordance with the legislation of Ukraine, political activity in the Armed Forces is limited. Military personnel stop membership in political parties and trade unions for the period of military service.

Military personnel can be members of public associations, except associations, statutory provisions which are contrary to the principles of the Armed forces of Ukraine, and may participate in their work in free from military duties when they are considered as such that do not fulfill military duties.

The organization of military strikes and participation in their conduct is not allowed.

Military personnel and employees of the Armed Forces of Ukraine may be restricted in freedom of movement, free choice of place of residence and the right to freely leave the territory of Ukraine, the right to collect, use and disseminate information in accordance with the law.

Employees of the Armed Forces of Ukraine suspend membership in political parties for the period of work in the Armed Forces of Ukraine.

The functioning of trade unions of employees who have concluded an employment contract with the Armed Forces of Ukraine is carried out in accordance with the Law of Ukraine "on trade unions, their rights and guarantees of activity".

Organization of strikes by employees of the Armed Forces of Ukraine and participation in their conduct are not allowed.

Every soldier is guaranteed the right to profess any religion or not to profess any.

Servicemen are given the opportunity to individually or collectively perform religious cults and rituals, conduct religious activities in compliance with the requirements of the Constitution of Ukraine and the laws of Ukraine.

7 On public procurement: Law of Ukraine of 10.04.2014 No. 1197-VII). URL: http://zakon2.rada.gov.ua/laws/show/1197-18 
At the same time, military personnel are guaranteed basic political and civil rights. Military personnel-citizens of Ukraine who serve in Ukraine, take part in all-Ukrainian and local referendums, elect and can be elected to the Verkhovna Rada of Ukraine, regional, district councils, other elected state bodies according to the Constitution of Ukraine

They are subject to the provisions of the Law of Ukraine "on elections of the President of Ukraine".

To the military personnel who stand candidates for people's deputies, their commanders (chiefs) have to create appropriate conditions for implementation of this right.

Military personnel elected to Councils or appointed to bodies formed by these Councils remain in military service and retain the status of military personnel. Soldiers, who are people's deputies, released from duty in connection with election to the authorities of the respective Councils, and not expressed a desire to retire to the reserve, comment to these Tips leaving for military service in the order established by the Cabinet of Ministers of Ukraine. The term of service in the Soviets or their bodies shall be counted in the total and continuous length of military service. After the end of the term of office of the Council of people's deputies and its bodies, the soldier goes to a military formation, where he served until the election for further service on positions not below that which he held until election to an elective office in the Council ${ }^{8}$.

Military personnel have the right to establish their public associations in accordance with the legislation of Ukraine. Military personnel may not be members of any political parties or organizations or movements. The organization of military strikes and participation in their conduct is not allowed.

Military personnel have the right to appeal to court illegal actions of military officials and bodies of military management.

Military personnel have an equal right to travel abroad with all citizens of Ukraine.

The last provision requires clarification. In accordance with the Constitution of Ukraine, everyone who legally resides on its territory is guaranteed freedom of movement, free choice of place of residence, the right to freely leave the territory of Ukraine, except for restrictions that are established by law. In accordance with article 17 of the Law of Ukraine "on the Armed Forces of Ukraine" servicemen may be restricted in freedom of movement.

\footnotetext{
${ }^{8}$ About bases of internal and foreign policy: the Law of 01.07.2010 No. 2411-VI. URL: http://zakon1.rada.gov.ua/laws/show/2411-17
} 
Article 216 of the Charter of the internal service of the Armed Forces of Ukraine establishes the following order of movement of servicemen. Conscripts in their spare time and work have the right to move freely on the territory of the military unit, and when dismissed - within the garrison. Departure of officers, warrant officers (midshipmen), the military personnel passing military service under the contract, outside of garrison is carried out with the permission of the commander of military unit. Departure of conscripts outside the garrison (except in cases of departure on vacation or business trip) is prohibited.

In our opinion, the procedure of arrest of servicemen is not legitimate.

In accordance with the Disciplinary Charter of the Armed Forces of Ukraine the authorities of the corresponding commander, the chief, can arrest conscripts and military service under contract to the military rank of "Sergeant" (main the ship's petty officer). The Law of Ukraine "on approval of the Disciplinary Statute of the Armed Forces of Ukraine" makes a reservation that the provisions of article 9 of The international Covenant on civil and political rights and article 5 of the European Convention for the protection of human rights and fundamental freedoms do not apply to the arrest procedure.

It would be appropriate to cite the main provisions of international legal acts and the Constitution in this part.

Article 9, paragraph 1, of the international Covenant on civil and political rights.

Everyone has the right to liberty and security of person. No one shall be subjected to arbitrary arrest or detention. No one shall be deprived of his liberty except on such grounds and in accordance with such procedure as are prescribed by law.

Article 5, paragraph 1, of the European Convention for the protection of human rights and fundamental freedoms.

Everyone has the right to liberty and security of person. No person may be deprived of his liberty except in accordance with the procedure established by law.

Part 2 of article 29 of the Constitution of Ukraine.

No one may be arrested or detained except by a reasoned decision of the court and only on the grounds and in the manner prescribed by law.

It seems that the legislator in this case ignored the provision of its own Constitution. After all, no reservations can be made about the Constitution. If to consider that in relation to the arrested military personnel in cases defined by the Charter of garrison and guard services the weapon (Art. 202, 241 of the Charter of garrison and guard services) can be applied, then the situation needs to be corrected immediately. 
The scope of rights and duties of military personnel is different depending on the positions they hold and military ranks. Service relations are characterized by signs of subordination and subordination. Commanders (chiefs) have the right to give orders (orders), and subordinates are obliged to carry them out. The Constitution of Ukraine (article 60) States that no one is obliged to carry out clearly criminal orders or orders.

For the giving and execution of an obviously criminal order or order comes legal responsibility. But in the relations of subordination and subordination it is also necessary to distinguish the concept of legal and illegal, lawful and unlawful, criminal and delict orders. The nature of such a legal category as an order (order) is sufficiently fully analyzed in the monograph of K. Dyachuk.

In the course of military service, citizens of Ukraine exercise the constitutional right to work (article 43 of the Constitution of Ukraine). At the same time, they are forbidden to engage in entrepreneurial activities (article 8 of the Law of Ukraine "on social and legal protection of servicemen and members of their families"). The law does not allow the use of military personnel to perform tasks not related to military service.

In respect of citizens of Ukraine serving in the Armed Forces of Ukraine and other military formations, as well as members of their families, the state provides social protection and their legal protection. The legislation of Ukraine for persons undergoing military service or otherwise perform military duty establishes a number of benefits. Benefits in this case should be understood as certain advantages for obtaining material benefits provided to citizens of Ukraine in connection with the performance of General military duty and military service. The provision of benefits can be regarded as a kind of compensation for restrictions, for certain deprivations imposed on military personnel. The basic law establishing privileges for military personnel is the Law of Ukraine "On social and legal protection of military personnel and members of their families". Disclosure of the scope and content of specific subjective rights of servicemen to benefits requires separate coverage. Analyzing the features of the legal status, it is important to note that the subjective right of servicemen to benefits is a necessary element of it (status).

Thus, the following can be attributed to the peculiarities of the legal status of military personnel:

- special rights and duties are established by special acts of legislation, military regulations, orders, advisers, installations, instructions;

- restriction of political activity (prohibition of participation in strikes, participation in political parties); 
- restrictions on freedom of movement (article 17 of The law of Ukraine "on the Armed Forces of Ukraine", article 216 of the Charter of the internal service of the Armed Forces of Ukraine);

- encroachment on the freedom and inviolability of military personnel (arrest);

- dependence of the legal status on the position and military rank;

- prohibition to engage in business activities;

- subjective entitlement to benefits.

- special procedure for bringing to administrative and material responsibility;

- military personnel act as a special subject in the composition of war crimes (Chapter 11 of the Criminal code of Ukraine).

\section{CONCLUSIONS}

Thus, the understanding of the military personnel of the above issues, awareness of the nature of the legal status, will contribute to an active legal position, the desire to fully realize and, if necessary, to protect their rights, as well as to conscientiously perform their duties in military service.

\section{SUMMARY}

International standards of human rights and freedoms and military service. Constitutional guarantees of human rights and freedoms in Ukraine. Delineation of the concepts of legal status and legal status of the individual. The legal status of military personnel in Ukraine. Problematic issues of ensuring human rights and freedoms in military service. Military personnel as a subject and object of national security. Civilian control over the military sphere as one of the effective means of ensuring human rights during military service. Validity and legality of restrictions in the rights and freedoms in the conditions of military service. International experience in the field of ensuring the rights and freedoms of servicemen and the possibility of its use in Ukraine.

Characteristics of the system, mechanisms, means, bodies, organizations, persons for the protection of human rights. State means of protection of human rights. Judicial protection of human rights. General characteristics of the judiciary. Constitutional right to judicial protection. Civil proceedings. Appeal in court of decisions, actions and inaction of public authorities, local self-government, officials and officials. Appeal to the military court with a complaint against illegal actions of officials of military administration. Criminal proceedings. Protection of the rights of the suspect, the accused, the defendant, the victim. Constitutional Court Of Ukraine. Commissioner of the Verkhovna Rada for human rights. Administrative and legal forms of 
human rights protection. The right to appeal (complaint) and its implementation in the conditions of military service. Public organizations and protection of human rights. International instruments for the protection of human rights. Control bodies established under the UN Charter. United Nations Commission on human rights (1946). United Nations high Commissioner for human rights (1993). The mechanism of individual complaints. Problems of efficiency of activity of control bodies and functioning of control mechanisms. European Commission on human rights. European Court of human rights. Appeal to the European Court of human rights. OSCE monitoring activities on the implementation of States obligations in human rights. Non-governmental organizations for the protection of human rights.

\section{REFERENCES}

1. Constitution of Ukraine of 28.06.1996 No. 254k/96-BP. URL: http://zakon4.rada.gov.ua/laws/show/254\%D0\%BA/96-\%D0\%B2\%D1\%80

2. Code of Ukraine on administrative offences of 07.12.1984 № 8073-XII. URL: http://zakon3.rada.gov.ua/laws/show/80731-10

3. The code of administrative proceedings of Ukraine of 06.07.2005 № 2747-IV. URL: http://zakon2.rada.gov.ua/laws/show/2747-15

4. The criminal code of Ukraine of 05.04.2001 № 2341-III URL: http://zakon2.rada.gov.ua/laws/show/2341-14

5. Civil code of Ukraine of 16.01.2003 № 435-IV URL: http://zakon4.rada.gov.ua/laws/show/435-15

6. Economic code of Ukraine of 16.01.2003 No. 436-IV. URL: http://zakon0.rada.gov.ua/laws/show/436-15

7. About Armed Forces of Ukraine: The Law of Ukraine of 06.12.1991 No. 1934-XII. URL: http://zakon2.rada.gov.ua/laws/show/1934-12

8. About social and legal protection of the military personnel and members of their families: the Law of Ukraine of 20.12.1991 No. 2011-XIIP. URL: http://zakon4.rada.gov.ua/laws/show/2011-12

9. About defense of Ukraine: The Law of Ukraine of 06.12.1991 No. 1932-XII. URL: http://zakon2.rada.gov.ua/laws/show/1932-12

10. About alternative (non-military) service: The Law of Ukraine of 12.12.1991 No. 1975-XII. URL: http://zakon4.rada.gov.ua/laws/show/ 1975-12

11. About use of lands of defense: The Law of Ukraine of 27.11.2003 No. 1345-IV. URL: http://zakon2.rada.gov.ua/laws/show/1345-15

12. On military duty and military service: Law of Ukraine from 25.03.1992, No. 2232-XII of the URL: http://zakon2.rada.gov.ua/laws/ show/2232-12 
13. About Military service of a law and order in Armed Forces of Ukraine: The Law of Ukraine of 07.03.2002 No. 3099-III. URL: http://zakon4.rada.gov.ua/laws/show/3099-14

14. About economic activity in Armed Forces of Ukraine: The Law of Ukraine of 21.09.1999 No. 1076-XIV. URL: http://zakon1.rada.gov.ua/ laws/show/1076-14

15. About democratic civil control over the Military organization and law enforcement agencies of the state: The Law of Ukraine of 19.06.2003. No. 975-IV). URL: http://zakon2.rada.gov.ua/laws/show/975-15

16. About the state guarantees of social protection of the military personnel who leave service in connection with reforming of Armed Forces of Ukraine, and members of their families: the Law of Ukraine of 15.06.2004 No. 1763-IV). URL: http://zakon2.rada.gov.ua/laws/show/ 1763-15

17. About bases of internal and foreign policy: The Law of 01.07.2010 No. 2411-VI. URL: http://zakon1.rada.gov.ua/laws/show/2411-17

18. On public procurement: Law of Ukraine of 10.04.2014 No. 1197-VII). URL: http://zakon2.rada.gov.ua/laws/show/1197-18

19. On international treaties of Ukraine: Law of Ukraine of 29.06.2004 No. 1906-IV). URL: http://zakon1.rada.gov.ua/laws/show/1906-15

20. About mobilization preparation and mobilization: the Law of Ukraine of 21.10.1993 No. 3543-XII P. URL: http://zakon2.rada.gov.ua/ laws/show/3543-12

\section{Information about the author:} Chebotareva G. V.,

Doctor of law, Professor,

Professor at the Department of Administrative,

Criminal Law and Procedure, International University of Business and Law 37-A, 49 HGD str., Kherson, 73040, Ukraine 


\section{THEORETICAL-LEGAL CHARACTERISTICS OF LEGAL CONFLICT IN LEGAL RELATIONS ON ADMINISTRATIVE SUPERVISION}

\section{Denysova A. V.}

\section{INTRODUCTION}

The need to formalize the implementation determinant of certain types of administrative supervision, in particular in the areas of public security and order, combating corruption and taking into account the implementation peculiarities of certain procedures of administrative supervision of the executive authorities, makes relevant the use of scientific potential of legal conflictology, which is of particular importance in administrative supervision's context. The expediency of addressing the legal conflict in the relations with regard to administrative supervision by the state executive power organs from the appointment of supervision, which consists in establishing the degree compliance by a entity whose activity is a supervision item prescribed by the legislation. The legal conflict's essence follows from its features, which are recorded in the current legislation in the form of special legal states, conflict situations, prohibitions, as well as violations of established legal requirements. This means that the existence of legal requirements and the obligation to comply with them is a conflicting factor affecting the legal relationship, as well as the administrative supervision of the state executive bodies.

Selection of groups of administrative proceedings, which are based on the existence (absence) of a conflict of legal importance. Conflicts and nonconflicts proceedings are distinguished, and the latter's subject are those in the course of which it is not obligatory to carry out a legal assessment of a person's behavior in relevant legal relationships. Conflict proceedings are those that underpin administrative-legal conflict, and therefore the legal assessment of a person's conduct in legal relationships.

It is advisable to classify administrative supervision proceedings as conflicting, since their implementation involves the provision of a legal assessment as a result of inspections or other measures (e.g. monitoring).

\section{Signs of administrative-legal conflict}

In the area of administrative supervision by the executive authorities, it is advisable to distinguish among the signs of administrative and legal conflict those which are caused by the peculiarities of the said activity:

- it always has a public-legal nature, since it arises from a public-legal relationship; 
- arises from legal relations connected with the implementation by the authorized bodies of the state executive power of executive activity aimed at establishing the compliance's degree of the entity's activity;

- whose activity are subject to administrative oversight;

- the current legislation, as well as guaranteeing safety in certain spheres of life of population.

The content and nature of the administrative-legal conflict in the legal relations concerning the implementation of administrative supervision consists in the existence of conflicting interests in the subjects of relations in the implementation of administrative supervision, one of which is always a state-authorized entity with a special legal status and performing state-power functions, and another entity whose activities are subject to administrative oversight does not perform such functions.

The last sign of administrative-legal conflict in the activities of state executive bodies in the exercise of administrative supervision follows from the following signs of legal conflict: a) the presence of contradictions or conflicts in the parties to the conflict; b) the existence of conflicting interests in the sphere of activity of the executive authorities on one subject; c) presence of the conflict subject with legal status; d) the decision within the limits of a certain legal procedure determined by administrative and legal norms; e) the existence of legal consequences of a decision, which is manifested, in particular, in the procedures for bringing to one of the types of legal responsibility (administrative, disciplinary, criminal), or imposing financial sanctions in the form of fines, or in denial of permits, or in restoration of the infringed right, etc ${ }^{1}$.

Appeal to legal encyclopedic publications indicates the insight of the category's essence of "public-legal dispute" as a type of legal dispute that arises between participants of public-legal relations in connection with violation, application or interpretation of rules of public branches of law. Contradictions that characterize the content of a public-law dispute are expressed in the differences in the legal positions of participants in a publiclaw relationship regarding their rights and obligations or the legality of a lawful (administrative) or normative act $^{2}$.

In "Great Encyclopedic Legal Dictionary" the category's content of "public-legal dispute" coincides with the category "public-legal conflict",

${ }^{1}$ Гасанова А. К. Адміністративно-правові засади вирішення конфліктів в діяльності органів виконавчої влади: дис..к.ю.н. 12.00 .07 - адміністративне право і процес; фінансове право; інформаційне право / Гасанова Антоніна Керимівна / Національний університет "Одеська юридична академія”. Одеса, 2011. 215 с.

${ }^{2}$ Великий енциклопедичний юридичний словник / За ред.. акад.. НАН України Ю. С. Шемшученка. 2-ге вид., переробл.і доповн. К.: Вид-во “Юридична думка", 2012. $1020 \mathrm{c}$. 
since the sole legal phenomenon - the contradiction between these relations' participants, is based on their content's insight.

Considering that the category of "public-legal dispute" is used in the current legislation - the Code of Administrative Procedure of Ukraine - it is possible to propose to provide a broad and narrow understanding of the public-legal dispute. The broad understanding presented above by Yu.S. Pedko is the author of the corresponding definition in the Great Encyclopedic Legal Dictionary. In the broad sense, the categories "publiclegal dispute" and "public-legal conflict" are identical in meaning. A narrow understanding of the category of "public-law dispute" is limited to its definition as a subject of judicial administrative jurisdiction.

In administrative out-of-court jurisdiction, administrative-legal conflict is regarded as an administrative-legal phenomenon, derived from a public-legal conflict. This means that the category of "public-legal conflict" is generic, and "administrative-legal conflict" is a generic one. It should be borne in mind that the content of the administrative-legal conflict is revealed through its elements: parties (subjects), subject matter and grounds for occurrence. Such elements constitute the construction of a public-law dispute ${ }^{3}$ and can be used to characterize administrative-legal conflicts in the activities of executive authorities as the basis for the emergence of procedural administrative-judicial extrajudicial relations. At the same time, this approach is not unique in identifying elements of legal conflict (dispute). A.K. Hasanov proposes that elements of legal conflict in the activity of executive bodies include: a) parties (entities); b) the subject; c) the content.

Comparison of the above approaches to the selection of legal conflict's elements, public-legal dispute indicates that they differ in the content of the conflict and grounds for the dispute. In this context, it should be noted that the need to identify the grounds for a dispute or conflict arises when the task of preventive measures is implemented in order to prevent or resolve a conflict or controversial situation. Identifying the cause of the dispute allows us to find out the outside of this legal phenomenon. Internal features of the administrative-legal conflict in the activity of executive authorities can be characterized using the approach proposed by A.K. Hasanov, on the composition of elements of administrative-legal conflict.

Thus, the elements of administrative and legal conflict in the activities of executive authorities include: a) parties (entities); b) the subject;

\footnotetext{
${ }^{3}$ Тимошенко К. О. Публічно-правовий спір як предмет юрисдикції адміністративних судів: автореф. дис.. к.ю.н. 12.00.07 - адміністративне право і процес; фінансове право; інформаційне право/ Тимошенко Катерина Олегівна / Інститут держави i права ім. В. М. Корецького НАН України. К., 2012. 20 с.
} 
c) the content. The need to include the subject matter and content as elements of administrative and legal conflict in the activities of executive bodies is based on the essence of these categories. So revealing the essence of these categories from the standpoint of philosophy allows us to note the following. Content reflects a system of interrelated components, properties, and processes that determine the specificity and development of an object. Subject ia any object that appears to be restricted or complete, why the properties may belong, and may have some relationship with other objects ${ }^{4}$. Thus the inner essence of a certain phenomenon, its properties, are characterized by content, and the boundaries of the phenomenon are delineated by the object.

However, the characterization of the administrative-legal conflict structure can be carried out in case of the types of such conflicts.

The signs of administrative and legal conflict include:

- the presence of conflicting or incompatible interests of participants in administrative and legal relations that arise within the specified legal relationship and relate to the same subject;

- participants in administrative-legal conflict have the appropriate administrative-legal status;

- such a conflict is resolved within the administrative procedure established by law;

- there are legal consequences of resolving an administrative-legal conflict, related to the restrictions or relying on the subject, whose activity is subject to administrative supervision, the obligation to take certain actions provided by the current legislation.

- there are legal consequences of resolving an administrative-legal conflict, related to the restrictions or relying on the subject, whose activity is subject to administrative supervision, the obligation to take certain actions provided by the current legislation.

These signs of administrative-legal conflict are formulated on the basis of signs of legal conflict, taking into account the specifics of the emergence of administrative-legal conflict - the sphere of exercise by the public power entities (among them bodies of executive power) the powers of jurisdictional content.

Among the signs of administrative and legal conflicts, the first place indicates the signs of incompatibility or conflict of interest. Revealing the essence of the category of "interest", it is expedient to proceed from its constitutional and legal content, reproduced in the legal position of the Constitutional Court of Ukraine "In the case of the constitutional submission

${ }^{4}$ Философия: энциклопедический словарь / под ред. А. А. Ивина. М.: Гардарики, 2006. $1072 \mathrm{c}$. 
of the 50 People's Deputies of Ukraine on the official interpretation of certain provisions of part one of Article 4 of the Civil Procedure Code of Ukraine (case of interest protected by law)" No. 18-2004 of 01.12.2004, namely its resolution part. Thus, in paragraph 1 of the resolution part of the decision, it stated that the concept of "law-protected interest" used in part one of Art. 4 of the Civil Procedure Code of Ukraine and other laws of Ukraine in a logical and meaningful connection with the concept of "a right", should be understood as the desire to use a specific material and / or intangible welfare, as determined by the general content of the objective and not directly mediated in the subjective law is a simple legitimate solution that is an independent object of judicial protection and other legal remedies in order to meet individual and collective needs that are not contrary to the Constitution and laws of Ukraine, the public interest, justice, integrity, reasonableness and other general legal principles 5 .

Therefore, the category of "interest" in its legal meaning means legitimate interest, which is manifested in the legislative regulation of the respective rights and freedoms.

Administrative-legal conflicts that give rise to administrative oversight relationships can be called administrative-legal conflicts in rule of law. Such a proposal is based on the essence of the category of "rule of law", which is revealed through public relations based on law. Rule of law is the ordering of legal, political, economic social and other relations by means of laws and other legal acts. It is, in fact, the result of the implementation of rules of law, accurate and steady implementation of laws and other normative legal acts, i.e. legality. The contradictions that arise in this area do not necessarily lead to the emergence of administrative-tort relations in connection with the commission of administrative tort or violation of rights, freedoms, legitimate interests, but act as conditions of occurrence.

Thus, an administrative-legal conflict in the sphere of administrative oversight of the executive authorities is a legal phenomenon, which is public and legal in nature, and concerns the existence of entities, one of which is endowed with a special legal status and performs state-governmental functions with opposite interests in legal relations, related to the implementation of enforcement activities aimed at establishing the degree and degree of compliance of the entity subject to administrative supervision, current legislation, as well as guaranteeing safety specific areas of the population.

5 У справі за конституційним поданням 50 народних депутатів України щодо офіційного тлумачення окремих положень частини першої статті 4 Цивільного процесуального кодексу України (справа про охоронюваний законом інтерес): рішення Конституційного Суду України від 01.12.2004 p. № 18-рп/2004// Офіційний вісник України. 2004. № 50. Ст. 3288. 
Such administrative-legal conflicts are administrative-legal conflicts in the field of law and order. They can be summarized in two groups: 1) tort conflicts, which in turn are divided into administrative-tort and disciplinary; 2) conflicts that result in a person exercising the right of appeal in an administrative manner.

However, the systematization of administrative and legal conflicts in the field of rules of law, which are considered from the standpoint of determining the use of certain types of administrative oversight of the executive authorities, involves taking into account the subject of a certain type of administrative supervision.

Thus, the Law of Ukraine "On State Market Supervision and Control of Non-Food Products" of 02.12.2010 No. 2735-VI ${ }^{6}$ stipulates that state market surveillance (hereinafter-market surveillance) is the activity of market surveillance authorities in order to ensure the conformity of products with the established requirements, as well as ensuring that there are no threats to the public interest (Article 1). Specific requirements for the exercise of market surveillance for specific types of products may be laid down in technical regulations (Part 2 of Article 2). The purpose of market surveillance is to take restrictive (corrective) measures with appropriate publicity for products that, when used for their intended purpose or reasonably foreseeable conditions and with proper installation and maintenance, pose a threat to the public interest or which otherwise does not meet the public interest requirements (Part 1, Art. 4).

Therefore, based on the above-mentioned regulatory requirements for the implementation of state market surveillance, its determinant is a conflict related to the violation of technical regulations, established product requirements or the presence of threats to the public interest. Conflict of state market surveillance determines its purpose for applying certain restrictive measures as a result of carrying out appropriate procedures. Such restrictive (corrective) measures are: a) restriction of production on the market; b) prohibition of making products on the market; c) withdrawal of products from circulation; d) recall of products (paragraph 2 of Part 1 of Article 22 of the Law of Ukraine "On State Market Supervision and Control of Non-Food Products" of 27.12.2010 No. 2735-VI). In the cases stipulated by the Law of Ukraine "On general safety of non-food products" No. $2736-\mathrm{VI}^{7}$ of 02.12 .2010 , the following market surveillance measures are

${ }^{6}$ Про державний ринковий нагляд і контроль нехарчової продукції: Закон України від 02.12.2010 № 2735-VI // Офіційний вісник України 2010, N 101 (10.01.2011), ст. 3602.

7 Про загальну безпечність нехарчової продукції: Закон України від 02.12.2010 № 2736-VI // Офіційний вісник України, 2010, N 101 (10.01.2011), ст. 3603. 
applied to the products that are in the consumers (users): 1) restricting the provision of products to the market; 2) recall of products (Part 3 of Article 22 of the Law of Ukraine "On State Market Supervision and Control of Non-Food Products" of December 27, 2010 No. 2735-VI). These measures are restrictive in nature, although they do not belong to administrative responsibility.

Given the existence of the right to apply restrictive measures in connection with violation of legal requirements and restrictions on the consequences of exercising a separate subspecies of administrative supervision of executive bodies - state market surveillance, it is advisable to supplement the list of tort conflicts, the subject of which is related to the existence of legal requirements.

Thus, the systematization of administrative-legal conflicts in the field of law and order as a determinant of the exercise of administrative supervision by the state executive authorities provides for the allocation of:

1) tort conflicts, which are divided into: a) administrative and tort; b) conflicts, the subject of which is related to the presence of legal requirements and restrictions; c) disciplinary conflicts;

2) managerial conflicts, the existence of which is the basis of administrative appeal.

Administrative-legal conflicts include a group of tort conflicts, which may result in administrative misconduct or disciplinary misconduct, as well as conflicts that are subject to legal requirements and restrictions.

According to Part 1 of Article 9 of the Code of Ukraine on Administrative Offenses (hereinafter referred to as the Code of Administrative Offenses) ${ }^{8}$, an administrative offense (misdemeanor) is recognized as unlawful, guilty (intentional or negligent) act or omission that infringes on public order, property, rights and freedom of citizens, in accordance with the established procedure of administration and for which the law provides for administrative responsibility.

Based on the prescriptions of Part 1 of Article 9 of the Code of Administrative Offenses, the parties to the administrative-delict conflict may act as a person who has violated mandatory rules and who should bear administrative responsibility for such violation, on the one hand, and the state as the authorized bodies charged with the duty to provide, preserve public order, public safety, established management order. The object of the emergence of conflicting interests in an administrative-tort conflict, which results in an administrative act, are relations in the public order sphere,

\footnotetext{
${ }^{8}$ Кодекс України про адміністративні правопорушення від 07.12.1984 № 8073-Х // Відомості Верховної Ради УРСР, 1984, додаток до N 51, ст. 1122.
} 
property, rights and freedoms of citizens, established management order. The opposite of interests is thus manifested by the unlawfulness of the act of the subject of administrative misconduct and the duty of the authorized state bodies to exercise legal protection and protection against unlawful encroachments.

In this case, the conflict of interests is characterized by the position of social and legal, because a person, in violation of mandatory rules of conduct protected by the state, thereby encroaches on the rule of law. Conflict of administrative-tort relations is also manifested in their development, transformation into relations of administrative responsibility, when a person against whom a protocol on an administrative offense has been drawn up, is obliged to obey the established rules, regardless of the fact that there is an imperative interference with his private interests.

In this connection it is impossible to avoid the opinion of L.V. Koval which was referred to by D.M. Lukyanets, that the administrative-tortious attitude arises from the moment of committing an administrative misdemeanor, and responsibility in the narrow sense as the application of punishment, takes place only from the moment of recognition of the person guilty, his/her conviction ${ }^{9}$.

Characteristic of administrative misconduct from the standpoint of legal conflictology is appropriate, because this approach allows to identify the risks of possible violations of the existing order of bringing to administrative responsibility by identifying "conflict" factors in the implementation of authorized state bodies (their officials in administration of imperative administration) imperative powers within the framework of administrativejurisdictional proceedings in cases of administrative misconduct. However, should be taken into account, that the category of "conflict" in law is of social-importance, which indicates the need to take into account the moment of transition of the conflict state into a conflict relationship, which occurs when the administrative misconduct is discovered and the last signs of a legal fact are acquired.

It is possible to mention in this context the scientific controversy of P.P. Serkov with scientists who disputed on legal relations arising in cases of administrative offenses. Scientists, criticizing O.B. Zelentsov, E.B. Luparev, who stated that the current legislation directly provides for the possibility of a legal dispute on administrative and tax liability, noted the following. The "dispute" category is more inherent in situations related to general regulatory

\footnotetext{
9 Лук'янець Д.М. Адміністративно-деліктні відносини в Україні: теорія та практика правового регулювання: Монографія, - Суми: ВТД “Університетська книга", 2006. $367 \mathrm{c}$.
} 
norms, as well as administrative law, for example, on justification of satisfaction or refusal to satisfy any rights or responsibilities, but not in the case of administrative liability ${ }^{10}$.

The autjor should agree with the argument of P.P. Serkov and acknowledge that administrative-tort relations cannot be described as disputed. However, their conflict is obvious, but it should be noted that it is advisable to consider administrative-tort conflict as a condition for the emergence of tort relations.

A similar theoretical-legal analysis can be made regarding disciplinary misconduct, taking into account the peculiarities of disciplinary responsibility. O.V. Kuzmenko defines the following specific features of disciplinary responsibility: 1) the basis for the application of disciplinary measures is the commission of a disciplinary misconduct, i.e. violation of the rules or governing rules, the activities of collectives, enterprises, institutions, organizations, etc.; 2) as a rule, for disciplinary misconduct, a person is liable in the order of labor or official jurisdiction; 3) disciplinary responsibility provides for the application to the offender of a wide range of specific sanctions: verbal remarks; deprivation of another rank from the location of a military unit or ship ashore appointment out of turn to work attire; severe reprimand; disciplinary fine; placement in a cell or solitary confinement; arrest with custody at the guard house; withdrawal of incentives previously applied; warnings about incomplete job title; delaying the assignment of another special rank; demotion in a special rank (class rank); demotion; a one-step reduction in military rank with a transfer to a lower position; dismissal, etc ${ }^{11}$.

Taking into account the above specific features of disciplinary responsibility, it can be stated that the parties to the disciplinary conflict are the subjects of employment and labor relations, which are connected with each other by organizational subordination. The subject-matter of such a conflict concerns the employment-related interests of a career in the broad sense of the term with respect to public service employees. If you rely on the legislative definition of the term "public service", you should refer to the norm of paragraph 15 of Part 1 of Art. 3 of the Code of Administrative Judiciary of Ukraine, which states that public service - activity in state political positions, professional activity of judges, prosecutors, military service, alternative (non-military) service, diplomatic service, other civil

\footnotetext{
${ }^{10}$ Серков П.П. Административная ответственность в российском праве: современное осмысление и нове подходы: монография / П.П. Серков. М.: Норма: ИНФРА-М, 2012. $480 \mathrm{c}$.

${ }^{11}$ Кузьменко О.В. Адміністративно-процесуальне право України / [О.В. Кузьменко, Т.О. Гуржій] : підруч.; за ред. О.В. Кузьменко. К.: Атіка, 2007. 416 с.
} 
service, service in the authorities of the Autonomous Republic of Crimea, bodies Local Government. The content of a disciplinary tort conflict is in the conflict of interests of the subjects of labor relations.

Torts are the ones that are subject to legal requirements and restrictions. This subgroup of tort conflicts makes up the vast majority of conflicts as determinants of administrative oversight by state executive bodies. Particular conflicts are those conflicts, the subject of which is related to the presence of legal requirements and restrictions established in the field of public order and security, certain areas of ensuring the safety of life of the population.

\section{The essence of conflict as a determinant of implementation of control and supervisory activities by executive authorities}

Tort conflicts from the standpoint of determination of the exercise of control-supervisory activity by the state executive power bodies, it is necessary to emphasize that there are such restrictions, the consequence of violation of which is not bringing to administrative or other types of legal responsibility, but acceptance by the authorized bodies of state executive power (their officials) decisions in the form of legal acts that provide for specific legal consequences of burdensome nature against violators of established legal requirements and restrictions.

For example, state nuclear and radiation safety inspectors carrying out administrative oversight in accordance with the Procedure for State Supervision of Compliance with Nuclear and Radiation Safety Requirements, approved by the Cabinet of Ministers of Ukraine Decree No. 824 of November $13,2013^{12}$, are authorized to issue orders as written requirements addressed to legal entities, their officials and individuals in case of violation of the requirements of nuclear and radiation safety.

Thus, a written request issued to legal entities, their officials and entities - entrepreneurs in order to stop the identified breach of the requirements of nuclear and radiation safety, eliminate its consequences or take compensatory measures to mitigate such consequences. The decree is issued by state inspectors of nuclear and radiation safety, has a binding nature, and its requirements must be fulfilled within a specified term (p. 5 p. 2 of the "Procedure for carrying out state supervision of compliance with the requirements of nuclear and radiation safety", approved by the Cabinet of Ministers resolution Ukraine, dated November 13, 2013 No. 824).

${ }^{12}$ Про затвердження Порядку здійснення державного нагляду за дотриманням вимог ядерної та радіаційної безпеки: Постанова Кабінету Міністрів України від 13.11.2013 № 824 // Офіційний вісник України, 2013, N 91 (03.12.2013), ст. 3344. 
A written request issued to legal entities, their officials and natural persons - entrepreneurs with the purpose of limiting, stopping the operation of state surveillance facilities in case of failure to eliminate otherwise detected violations or failure to comply with the requirements of nuclear and radiation safety. The decree is also issued by state inspectors for nuclear and radiation safety, is mandatory and its requirements must be fulfilled within the specified time limits (p. 6 p. 2 of the "Procedure of state supervision over compliance with the requirements of nuclear and radiation safety", approved by the Cabinet resolution Ministers of Ukraine, dated November 13, 2013 № 824).

Characterizing the peculiarities of administrative supervision of state executive bodies, their individual types, determinants, it is necessary to pay attention, first of all, to the problematic issues of legal regulation and law enforcement practice.

In particular, the results of the audit of the effectiveness of state budget funds' using by the National Commission for State Regulation in the Field of Communications and Informatization of the Accounting Chamber found the lack of legal regulation of the activities of the said National Commission, the lack of ensuring the proper enforcement of the powers of the licensing authority assigned to it by special laws of Ukraine. the licensing authority, the regulatory body and the state oversight (control) body in the communications sector. It is stated that the Decree on the National Commission for State Regulation in the Field of Communication and Informatization (hereinafter - the Regulations) ${ }^{13}$, approved by Presidential Decree No. 1067/2011, contains tasks and functions that are not mandated by law. Contrary to the requirements of Art. 8 of the Law of Ukraine "On postal service" of 04.10.2001 No. 2759-III The National Commission did not establish the procedure for state supervision of the postal services market, which led to the actual lack of implementation of powers to carry out supervision. Also in violation of the requirements of PP. 30 Clause 4 Regulations The National Commission did not approve the procedure for keeping a register of postal operators ${ }^{14}$.

${ }^{13}$ Про Національну комісію, що здійснює державне регулювання у сфері зв'язку та інформатизації: Указ Президента України від 23.11.2011 № 1067/2011 // Офіційний вісник України, 2011, N 94 (12.12.2011), ст. 3417

14 Про результати аудиту ефективності використання коштів державного бюджету Національною комісією, що здійснює державне регулювання у сфері зв'язку та інформатизації: Рішення Рахункової палати України від 09.03.2016 № 4-3 [Електронний ресурс]: Режим доступу. Інформаційно-аналітична система "Ліга-закон" станом на 12.07.2017. 
Referral to the current legislation does not provide an opportunity to point out the deficiencies indicated by the Accounting Chamber by the National Commission, in particular, the lack of a regulatory framework for the state supervision of the postal services market. There is currently information on the draft such a document, developed in 2010, in the form of an annex to the NCCIR decision No. 406 of 09/09/2010 ${ }^{15}$.

The next group of administrative-legal conflicts as determinants of the implementation of certain types of administrative supervision are conflicts, in which a person complains to state authorities, local self-government, associations of citizens, enterprises, institutions, organizations regardless of ownership, mass media, officials persons.

The conflicting nature of the complaint as a form of appeal, as well as to the executive authorities, stems from the legislative definition of the relevant designation. According to Part 4 of Art. 3 of the Law of Ukraine “On Citizens' Appeals" of 02.10.1996 № 393/96-VR ${ }^{16}$, complaint is a petition for renewal of rights and protection of the legitimate interests of citizens, violated by actions (inaction), decisions of state bodies, local authorities self-government, enterprises, institutions, organizations, associations of citizens, officials. Based on this regulatory definition of "complaint", it is necessary to point out the following elements of the relevant conflict. The parties of the conflict is the entity that has the authority to make legally significant decisions or take legally significant actions, on the one hand, and on the other - a citizen, a stateless person, a foreigner who have the right to appeal such a decision, an action (inaction). The right of foreigners, stateless persons to file a complaint derives from part 1 of Article 26 of the Constitution of Ukraine, which stipulates that foreigners and stateless persons who are legally in Ukraine exercise the same rights and freedoms and have the same duties, as well as citizens of Ukraine - with the exceptions established by the Constitution, laws or international treaties of Ukraine, as well as part 3 of Article 1 of the Law of Ukraine "On Citizens' Appeals", where it is established that persons who are not citizens of Ukraine and are legally within its territory, have and the same right to file an appeal as the citizens of Ukraine, unless otherwise provided by international treaties. The subject matter and content of the administrative-legal conflict relating to the complaint concerns the violation of socio-economic, political and personal rights and legitimate interests.

15 Порядок здійснення державного нагляду за ринком послуг поштового зв'язку: Додаток до рішення НКРЗ від 09.09.2010 р. № 406. [Електронний ресурс]: Режим доступу. nkrzi.gov.ua/images/upload/70/2429/r406dod.doc.

${ }^{16}$ Про звернення громадян: Закон України від 02.10.1996 р. № 393/96-ВР // Відомості Верховної Ради України. 1996. № 47. Ст. 256. 
Considering administrative-legal conflicts from the standpoint of determination of the implementation of certain types of administrative supervision by executive authorities, it should be noted that such conflicts should be considered as conditions for the emergence of procedural administrative-jurisdictional relations related to bringing a guilty person to administrative responsibility or disciplinary liability or protection of citizens' rights. Such relationships result from the implementation of certain types of administrative supervision. First of all, supervision in the fields of public safety and order, control and supervision in the internal organizational activity of executive bodies, certain types of administrative supervision in the sphere of ensuring the vital activity of the population (state sanitaryepidemiological supervision, supervision in the field of technogenic and fire safety, etc.).

The basis of administrative responsibility is an administrative misconduct. Administrative responsibility is realized on the condition of non-official subordination, there is a large number of bodies authorized to impose administrative penalties, the rules of administrative law determine the order of imposition of administrative penalties ${ }^{17}$.

Among the grounds of administrative responsibility it is advisable to distinguish factual and legal (procedural) grounds. The factual basis for proceeding in an administrative offense case is the fact of committing such an offense, and the legal one is the information about the offense. Scientists say that, in addition, there are reasons to be justified. Such reasons should be recognized: appeals (written or oral) to citizens; notification of officials of state authorities and local self-government, enterprises, institutions and organizations; media reports; messages from associations of citizens; direct detection of a misdemeanor by an authorized official ${ }^{18}$.

V.G. Perepelyuk systematized the grounds for initiating proceedings and identifies three groups. 1. Persons' statements demanding the exercise of their rights or the protection of those rights and the submission of leading entities. Citizens' statements may be oral. It is therefore envisaged that the oral statements should be entered in the minutes signed by the applicant and the official who accepted the application. 2. Own initiative of leading subjects. In case a petition is received from the applicant about the possibility of negative consequences associated with the filing of the application and in order to protect his/her interests, the case is initiated on

\footnotetext{
${ }^{17}$ Адміністративне право України. Академічний курс: Підруч.: У двох томах: Том 1. Загальна частина / Ред. колегія: В.Б. Авер'янов (голова) та ін. К.: ТОВ “Видавництво "Юридична думка", 2007. 592 с.

18 Адміністративна діяльність ОВС. Загальна частина. Підручник / За загальною редакцією О.П. Рябченко. Х.: ХНУВС, 2009. 256 с.
} 
the initiative of the leading entity. 3. Communication in the media ${ }^{19}$. We can agree with this approach, because it allows distinguishing the very reasons that require due process registration. The above applies, in particular, to citizens' statements.

Analyzing the issue of grounds of administrative responsibility, one should not fail to point out the legislative and doctrinal novelty - a category of criminal misconduct, the necessity of which was foreseen by the Concept of reforming criminal justice of Ukraine, approved by the Decree of the President of Ukraine of 15.02.2008 ${ }^{20}$. The following are proposed to be distinguished: 1) separate acts, which under the current Criminal Code of Ukraine belong to crimes of low gravity, which in accordance with the policy of humanization of criminal legislation will be determined by the legislator such that they do not have a significant degree of public danger; 2) envisaged by the current Code of Ukraine on Administrative Offenses that have judicial jurisdiction and are not administrative in nature (petty hooliganism, petty theft, etc.). The criminal offenses were to be divided into crimes and criminal offenses, as well as the unification of criminal proceedings under the new Criminal Procedure Code of Ukraine with civil and administrative justice, but as far as the peculiarities of the subject matter and the task of criminal justice.

The implementation of these strategic objectives is extremely difficult, given, first of all, the doctrinal uncertainty of this category itself. In the course of the scientific discussion, scientists express their opinion on the transformation of criminal rather than administrative legislation, linking it with the novelties of the Criminal Procedure Code of Ukraine, which provides for two types of criminal offense: crime and criminal offense ${ }^{21}$. Processing of this problem's results discussion among the leading domestic legal scholars has made the following conclusions. First of all, the adoption of the law on criminal offenses provides for the elimination of criminal law conflict, when the Criminal Procedure Code of Ukraine provides for the existence of criminal offenses, and the Criminal Code of Ukraine dated 23.04.2001 № 2341-III-no. The introduction of the institution of criminal misconduct into the legal system of Ukraine is connected with the reform of a number of law branches, including constitutional, criminal,

\footnotetext{
${ }^{19}$ Перепелюк В.Г. Адміністративний процес. Загальна частина: Навчальний посібник. Чернівці: Рута, 2003. 367 с.

${ }^{20}$ Про рішення Ради національної безпеки і оборони України від 15 лютого 2008 року "Про хід реформування системи кримінальної юстиції та правоохоронних органів": Президент України; Указ, Концепція від 08.04.2008 № 311/2008 // Урядовий кур’єр від 17.04.2008. № 72 .

21 Кримінальний процесуальний кодекс України від 13.04.2012 № 4651-VI// Офіційний вісник України, 2012, N 37 (25.05.2012), ст. 1370.
} 
administrative ones. The current Constitution of Ukraine lays down the concept of a single criminal offense - a crime. Therefore, it is practically impossible to implement the amendments to the Constitution of Ukraine, to introduce the institution of criminal misconduct in full and in the correct legal way. Possible "truncated version": to give the "status" of criminal misdemeanors to misdemeanor, while conducting systematic changes to the current Criminal Code of Ukraine. The introduction of the institution of criminal misconduct into the legal system of Ukraine should be carried out within the general concept of humanization of criminal responsibility and criminal justice as a whole. This raises the question of the harmonization with the concept of transfer to the category of criminal offenses of individual administrative offenses. Problematic, but rather interesting, is the proposal to introduce a new form of criminal liability for committing a criminal offense - criminal penalties. This form, in particular, can resolve the issue of criminal liability of legal persons, as provided for by numerous acts of international law, as well as the conventions of the Council of Europe and the European Union ${ }^{22}$.

Therefore, the introduction of a criminal misconduct institute is related to the solution of several interconnected conceptual problems. First of all, the above refers to the substantive part of the criminal and administrative legislation on the elaboration at the doctrinal level of the concept of criminal misconduct. Secondly, the question arises about the type of legal responsibility for committing a criminal offense - criminal, administrative or justify the feasibility of forming a new type of legal liability, which, in turn, provides for amendments to the Constitution of Ukraine. Thirdly, a considerable amount of analytical work is required to identify criminal offenses from criminal crimes and administrative offenses. Fourth, the procedure for bringing a criminal offense to justice should be proposed.

The solution to the whole range of these tasks is a difficult task, however, it is necessary, consider the humanization of legal responsibility, the tendency of which is in line with international standards.

Consideration may be given to the unification of the procedures for judicial review of individual cases, as well as those relating to criminal offenses, on a competitive basis. In this connection, it should be noted that in the writings of K.S. Yudelson, the idea of supplementing the competitive beginning of the civil process with the beginning of investigators was consistently held ${ }^{23}$.

\footnotetext{
${ }^{22}$ Курінний Є.В. Предмет і об’єкт адміністративного права України: Монографія. Д.: Юрид. акад. М-ва внутр. справ; Літера лтд, 2004. 340 с.

23 Юдельсон К. С. Избранное. Советский нотариат. Проблема доказывания в советском гражданском процессе. - М.: Росс. прав. академия, 2005. 616 с.
} 
With regard to disciplinary proceedings as a procedure for imposing disciplinary sanctions, the theory of administrative law has been based on disciplinary responsibility ${ }^{24}$. In the sphere of executive bodies' activity, the subject of disciplinary responsibility is primarily a civil servant. As correctly emphasized by L.M. Kornuta, the application of disciplinary liability is both a measure of disciplinary coercion and a type of legal liability applicable to civil servants. To the peculiarities of this type of responsibility, the researcher attributes the fact that issues related to bringing a civil servant to disciplinary responsibility are governed by the norms of both administrative and labor law ${ }^{25}$.

Disciplinary misconduct does not always serve as a basis for disciplinary responsibility. According to Article 15 of the Code of Administrative Offenses of Ukraine, military, military duty persons and reservists during the meeting, as well as persons of the rank and file of the State Criminal Enforcement Service of Ukraine, bodies of the National Police and the State Service for Special Communication and Information Protection of Ukraine are responsible for administrative offenses under disciplinary statutes. Exceptions are violations of rules, rules and standards relating to road safety, hygiene and sanitary-epidemic rules and regulations, rules of hunting, fishing and protection of fish stocks, customs rules, committing corruption offenses, disturbance of silence in public places. the use of state property, the unlawful storage of special technical means of obtaining information in private, the failure to take action on a separate court order or a separate judge's order, or the filing of a prosecutor, critically departed from fulfilling the legal requirements of the prosecutor, violation of the law on state secrets, breach of registration, storage and use of documents and other media containing confidential information held by the state for which these persons bear administrative responsibility on general grounds.

An exception to the general rule on disciplinary responsibility regarding the grounds of disciplinary liability - a disciplinary offense commission - is provided by the Law of Ukraine "On Prevention of Corruption" of 14.10.2014 No. 1700-VII ${ }^{26}$. According to Part 5, Article 65 of the said Law, a person who has been informed of a suspicion of crime committing in the

${ }^{24}$ Адміністративне право [Текст] : підручник / Ю. П. Битяк (кер.авт.кол.), В. М. Гаращук, В. В. Богуцький та ін. ; за заг.ред. Ю. П. Битяка, В. М. Гаращука, В. В. Зуй. Х. : Право, 2010. 624 с.

25 Корнута Л. М. Особливості дисциплінарної відповідальності державних службовців в Україні // Збірник наукових праць “Адміністративне право України: стан і перспективи розвитку”: VI Міжнародна науково-практична конференція (м. Київ, 23-24 вересня 2011 року)// Ред.кол. О. Ф. Андрійко (голова ред..кол.). К.: Інститут держави і права ім. В. М. Корецького НАН України, 2011. 600 с. С. 479.

${ }^{26}$ Про запобігання корупції: Закон України від 14.10.2014 № 1700-VII // Відомості Верховної Ради України, 2014, N 49 (05.12.2014), ст. 2056. 
field of official activity shall be subject to removal from the exercise of his / her powers in the manner prescribed by law. A person for whom a protocol on administrative corruption offense has been drawn up, unless otherwise provided by the Constitution and laws of Ukraine, may be suspended from the exercise of official authority by the decision of the head of the body (institution, enterprise, organization) in which he/she works, pending the case conclusion by a court. Part two of Art. 65 of the said law establishes that the person who has committed a corruption offense or an offense related to corruption, but the court did not punish or impose it in the form of deprivation of the right to occupy certain positions or engage in certain activities related to corruption, however, the court did not apply or impose a penalty on him/her in the form of deprivation of the right to occupy certain positions or engage in certain activities related to the performance of functions of the state or local self-government, or equivalent to these activities, subject to disciplinary liability in the manner prescribed by law.

It should be noted that separate rules on liability for corruption or corruptionrelated offenses under Art. 65 of the Law of Ukraine "On Prevention of Corruption" has been preserved, compared to Art. 22 of the Law of Ukraine "On the Principles of Prevention and Combating Corruption". The above applies to the provisions on peculiarities of administrative liability.

Therefore, the regulation peculiarities of disciplinary liability by the current legislation include:

- determination of norms of both administrative and labor law;

- for some categories of officials, the basis of disciplinary liability is the commission of an administrative offense, including corruption.

Regarding the complaint as a procedural basis for the emergence of procedural administrative-jurisdictional relations, it should be noted that its content consists in the requirement to restore the rights and legitimate interests of citizens violated by actions (inaction), decisions of state bodies, local self-government bodies, institutions, organizations, unions of citizens, enterprises, officials. Formulation this content follows from Part 3 of Art. 3 of the Law of Ukraine "On Citizens Appeal". In this regard, E.Yu. Shved correctly emphasizes the substantive nature of the complaint, as evidenced by an experience analysis of the Institute of Administrative Justice. This applies to countries such as the Netherlands, Austria, Poland, France. In the last two countries, along with the complaint, the appeal right was established in the form of a statement of claim ${ }^{27}$.

27 Швед Е. Ю. Процесуальні акти-документи у адміністративному судочинстві: дис. ... к.ю.н. 12.00.07 - адміністративне право і процес; фінансове право; інформаційне право / Швед Едуард Юрійович / Харківський національний університет внутрішніх справ. Х., 2009. 200 с. 


\section{CONCLUSIONS}

The essence of a legal conflict stems from its features, which are recorded in the current legislation in the form of special legal states, conflict situations, prohibitions, as well as violations of established legal requirements. This means that the existence of legal requirements and the obligation to comply with them is a conflict factor that affects the legal relationship, as well as the administrative oversight of state executive bodies.

Therefore, conflicts in legal relations regarding the administrative supervision of state executive bodies can be considered:

- as determinants of the application of certain types of administrative supervision;

- as grounds for the emergence of administrative and legal relations on the consequences of administrative supervision.

In the first and second cases, there are two sets of administrative-legal conflicts: tort and administrative conflicts. When considering a legal conflict from the standpoint of determination of certain administrative control and supervisory relations, a subset of conflicts, the subject of which is related to the presence of legal requirements and restrictions, is additionally included. At the same time, it should be emphasized that under different legal conditions (determination or consequence) there is a difference in the content of the structural components of legal conflicts. Administrative-legal conflicts are combined into one type of legal conflict - administrative-legal conflict in the field of law and order.

Systematization of administrative-legal conflicts in the field of law and order as a determinant of administrative supervision by state executive bodies provides for the allocation of: 1) tort conflicts, which are divided into: a) administrative-tort; b) conflicts, the subject of which is related to legal requirements and restrictions; c) disciplinary conflicts; 2) management conflicts, the existence of which is the basis of administrative appeal.

\section{SUMMARY}

The essence of a legal conflict stems from its features, which are recorded in the current legislation in the form of special legal states, conflict situations, prohibitions, including - in violation of established legal requirements. This means that the existence of legal requirements and the obligation to comply with them is a conflicting factor that affects the legal relationship, including the administrative supervision of state executive bodies.

The elaboration of scientific approaches to determine the essence of categories "legal conflict", "administrative-legal dispute", "public-legal dispute" allowed to include in the elements of administrative-legal conflict 
in the activity of bodies of executive power its subject and content. Formulate general features of such of the conflict, on the basis of which the signs of administrative-legal conflict in the sphere of administrative supervision are formulated. Torts are the ones that are subject to legal requirements and restrictions. This subgroup of tort conflicts makes up the vast majority of conflicts as determinants of administrative oversight by state executive bodies. Particular conflicts are those conflicts, the subject of which is related to the presence of legal requirements and restrictions established in the field of public order and security, certain areas of ensuring the safety of life of the population.

\section{REFERENCES}

1. Гасанова А.К. Адміністративно-правові засади вирішення конфліктів в діяльності органів виконавчої влади: дис. к.ю.н. 12.00 .07 адміністративне право і процес; фінансове право; інформаційне право/ Гасанова Антоніна Керимівна / Національний університет “Одеська юридична академія". - Одеса, 2011. - 215 с.

2. Великий енциклопедичний юридичний словник / За ред.. акад.. НАН України Ю.С. Шемшученка. - 2-ге вид., переробл. і доповн. - К.: Вид-во “Юридична думка", 2012. - 1020 с.

3. Тимошенко К.О. Публічно-правовий спір як предмет юрисдикції адміністративних судів: автореф. дис.. к.ю.н. 12.00.07 - адміністративне право і процес; фінансове право; інформаційне право / Тимошенко Катерина Олегівна/ Інститут держави і права ім.. В.М. Корецького НАН України. - К., 2012. - 20 с.

1) 4.Философия: энциклопедический словарь / под ред. А.А. Ивина. - М.: Гардарики, 2006. - 1072c.

4. У справі за конституційним поданням 50 народних депутатів України щодо офіційного тлумачення окремих положень частини першої статті 4 Цивільного процесуального кодексу України (справа про охоронюваний законом інтерес): рішення Конституційного Суду України від 01.12.2004 р. № 18-рп/2004 // Офіційний вісник України. 2004. - № 50. - Ст. 3288.

5. Про державний ринковий нагляд i контроль нехарчової продукції: Закон України від 02.12.2010 № 2735-VI// Офіційний вісник України, 2010, N 101 (10.01.2011), ст. 3602.

6. Про загальну безпечність нехарчової продукції: Закон України від 02.12.2010 № 2736-VI // Офіційний вісник України, 2010, № 101 (10.01.2011), ст. 3603. 
7. Кодекс України про адміністративні правопорушення від 07.12.1984 № 8073-Х // Відомості Верховної Ради УРСР, 1984, додаток до № 51, ст. 1122.

8. Лук'янець Д.М. Адміністративно-деліктні відносини в Україні: теорія та практика правового регулювання: Монографія, - Суми: ВТД “Університетська книга", 2006. - 367 с.

9. Серков П.П. Административная ответственность в российском праве: современное осмысление и нове подходы: монография/ П.П. Серков. - М.: Норма: ИНФРА-М, 2012. - 480 с.

10. Кузьменко О.В. Адміністративно-процесуальне право України / [О.В. Кузьменко, Т.О. Гуржій] : підруч.; за ред. О.В. Кузьменко. - К.: Атіка, 2007. - $416 \mathrm{c}$.

11. Про затвердження Порядку здійснення державного нагляду за дотриманням вимог ядерної та радіаційної безпеки: Постанова Кабінету Міністрів України від 13.11.2013 № 824// Офіційний вісник України, 2013, N 91 (03.12.2013), ст. 3344.

12. Про Національну комісію, що здійснює державне регулювання у сфері зв'язку та інформатизації: Указ Президента України від 23.11.2011 № 1067/2011 // Офіційний вісник України, 2011, № 94 (12.12.2011), ст. 3417.

13. Про результати аудиту ефективності використання коштів державного бюджету Національною комісією, що здійснює державне регулювання у сфері зв'язку та інформатизації: Рішення Рахункової палати України від 09.03.2016 № 4-3 [Електронний ресурс]: Режим доступу. - Інформаційно-аналітична система “Ліга-закон” станом на 12.07.2017.

14. Порядок здійснення державного нагляду за ринком послуг поштового зв'язку: Додаток до рішення НКРЗ від 09.09.2010 р. № 406 [Електронний ресурс]: Режим доступу. - www.nkrzi.gov.ua/images/upload/ 70/2429/r406dod.doc.

15. Про звернення громадян: Закон України від 02.10 .1996 p. № 393/96-ВР // Відомості Верховної Ради України. - 1996. - № 47. Ст. 256.

16. Адміністративне право України. Академічний курс: Підруч.: У двох томах: Том 1. Загальна частина / Ред. колегія: В.Б. Авер'янов (голова) та ін. - К.: ТОВ "Видавництво "Юридична думка", 2007. $592 \mathrm{c}$.

17. Адміністративна діяльність ОВС. Загальна частина. Підручник/ За загальною редакцією О.П. Рябченко. - Х.: ХНУВС, 2009. - 256 с.

18. Перепелюк В.Г. Адміністративний процес. Загальна частина: Навчальний посібник. - Чернівці: Рута, 2003. - 367 с. 
19. Про рішення Ради національної безпеки і оборони України від 15 лютого 2008 року "Про хід реформування системи кримінальної юстиції та правоохоронних органів": Президент України; Указ, Концепція від 08.04.2008 № 311/2008 // Урядовий кур'єр від 17.04.2008. - № 72 .

20. Кримінальний процесуальний кодекс України від 13.04.2012 № 4651-VI // Офіційний вісник України, 2012, N 37 (25.05.2012), ст. 1370.

21.Курінний Є.В. Предмет і об'єкт адміністративного права України: Монографія. - Д.: Юрид. акад. М-ва внутр. справ; Літера лтд,2004. - $340 \mathrm{c}$.

22. Юдельсон К.С. Избранное. Советский нотариат. Проблема доказывания в советском гражданском процессе. - М.: Росс. прав. академия, 2005. - $616 \mathrm{c}$.

23. Адміністративне право [Текст] : підручник / Ю.П. Битяк (кер.авт.кол.), В.М. Гаращук, В.В. Богуцький та ін. ; за заг.ред. Ю.П. Битяка, В.М. Гаращука, В.В. Зуй. - Х. : Право, 2010. - 624 с.

24. Корнута Л.М. Особливості дисциплінарної відповідальності державних службовців в Україні // Збірник наукових праць “Адміністративне право України: стан і перспективи розвитку”: VI Міжнародна науково-практична конференція (м. Київ, 23-24 вересня 2011 року) // Ред. кол. О.Ф. Андрійко (голова ред. кол.). - К.: Інститут держави і права ім. В.М. Корецького НАН України, 2011. - 600 с. C. 479.

25. Про запобігання корупції: Закон України від 14.10.2014 № 1700VII // Відомості Верховної Ради України, 2014, N 49 (05.12.2014), ст. 2056.

26. Швед Е.Ю. Процесуальні акти-документи у адміністративному судочинстві: дис..к.ю.н. 12.00.07 - адміністративне право і процес; фінансове право; інформаційне право / Швед Едуард Юрійович / Харківський національний університет внутрішніх справ. - X., 2009. - 200 c.

\section{Information about the author: Denysova A. V.,} Doctor of Law, Associate Professor, Head of the Department of Administrative Law and Administrative Process, Odessa State University of Internal Affairs 1, Uspenska str., Odessa, 65000, Ukraine 


\section{PLACES AND FUNCTIONS OF CIVIL PROCEDURAL LEGAL RELATIONS IN THE MECHANISM OF CIVIL PROCESSING REGULATION}

\section{Didenko L. V.}

\section{INTRODUCTION}

The study of various theoretical aspects of civil procedural relations has always been the focus of procedural scientists. For many years, since the Soviet period, scientists have carried out both comprehensive studies of the theory of civil procedural relations, and studied the individual issues of nature and characteristics of the elements of their structure (subject composition, content, object). However, not many scholars have conducted the analysis of civil procedural relations as elements of civil procedural regulation today.

Therefore, the further development of civil procedural relations requires not only the general theoretical establishment of its essence, but also the definition of a role in the mechanism of civil procedural regulation. Such a study will also reflect the state and problems of the development of modern theory of civil procedural legal relations, since being the main way of realizing the rights and obligations of participants in civil proceedings, at the same time are an element of a much more complex formation - the mechanism of regulation. Therefore, much attention should be paid to the study of the place and functions of civil procedural relations in the mechanism of civil procedural regulation and their interaction with other constituent elements.

\section{The essence of the mechanism of civil procedural regulation}

In the general theoretical aspect, the "mechanism" is defined in the Great Interpretive Dictionary of Modern Ukrainian as an internal structure, a system of anything. That is, from a semantic point of view, this term means a set of interrelated elements. Therefore, the study of the structural parts of any mechanism should involve establishing both their place in such a system and their role in its functioning. Given that mechanism is a term characteristic of a number of spheres, it is important to analyze this concept precisely in the context of legal science.

Analyzing the views of scientists on the definition of the concept of "mechanism of legal regulation", let us note that the vast majority of them primarily operate with the definition proposed by S.S. Alekseev, since it was 
this researcher who first introduced it into scientific circulation. From the point of view of the scientist, the mechanism of legal regulation is taken in unity by a set of legal means by which legal influence on social relations is ensured. The structure of this mechanism is a set of means of legal influence, namely, such legal phenomena that "work" in the legal mediation of social relations. From this definition we can draw the following conclusions about the essence of the mechanism of legal regulation: 1) the mechanism of legal regulation consists of elements (legal remedies), which are considered above all in unity (act in a well-established and permanent relationship); 2) the purpose of the mechanism of legal regulation is to have a legal impact on public relations. We consider such a definition quite acceptable, given that it clearly reveals the essence of the mechanism, establishes its elemental composition and the specificity of the relationships between the elements. In addition, the disclosure of the essence of the mechanism in this way demonstrates that the term is indeed appropriate to use not only in the technical sciences, but also in the context of legal science.

With respect to the more modern views prevailing in domestic legal doctrine, let us note the point of view of A.F. The steed, which defines the mechanism of legal regulation as the process of transition of the normativity of law into the ordering of public relations, which is carried out by the subjects of legal regulation through the system of legal means, methods and forms in order to satisfy the public and private interests of participants of public relations, ensuring law and order.

Already from the list of features of the legal regulation mechanism taken into account by the researcher, we can conclude that this position is much more detailed. In particular, the researcher clearly establishes the participation of the subjects in the functioning of the mechanisms, identifies the tools for its implementation, draws attention to the systematic interaction of elements. Therefore, in general, we also consider this position to be sufficiently successful to form an understanding of the essence of the mechanisms of legal regulation.

Other positions of scientists are less perfect in this aspect. For example, S.T. Goncharuk, by the concept of the mechanism of legal regulation, understands the system of legal elements through which the legal regulation (ordering) of social relations is carried out ${ }^{1}$. Thus, the main provisions of this definition are: 1) the mechanism of legal regulation is explained as a system of legal elements; 2) the purpose of the mechanism of legal regulation is the legal regulation (ordering) of social relations.Such a position actually

\footnotetext{
${ }^{1}$ Гончарук С. Т. Адміністративне право України : навч. посіб. К. : Генеза, 2000.
} 
duplicates the point of view of S.S. But in general, it is not characterized by controversial elements or formulations.

Therefore, in general, the analyzed positions indicate that in legal science there is a unity of positions on the interpretation of the concept of "mechanism". In essence, the main model is the position of SS. Alekseeva ${ }^{2}$, which has been repelledby a number of scientists, but some researchers, including A.F. Horse Rider, significantly expand the essence of this concept. A common understanding is the interpretation of the mechanism of legal regulation as a system of legal means, methods and forms, which are its elements, which have a positive effect on social relations in order to regulate and regulate them.These elements are considered in unity, that is, acted in a smooth and constant manner. As a result of the mechanism of legal regulation, its subjects embody legal means, methods and forms, which allows to satisfy the public and private interests of participants in public relations and to ensure law and order.

Therefore, the main purpose of the mechanism of legal regulation is to give the relations of the subjects of normativity and satisfaction of interests of such persons. In general, the elements of the mechanism of legal regulation include legal remedies, methods and forms. Therefore, let us conclude that the legal nature of the mechanism of civil procedural regulation is based on a well-defined set of elements combined by interaction and common purpose.

Before moving on to the analysis of the constituent elements of the mechanism of civil procedural regulation, we consider it necessary to specify what is meant by this concept. S.V. Kymchinskaya defines the mechanism of legal regulation of civil procedural relations as a systematic set of complex, mutually agreed procedural legal means by which the state ensures the effective influence of civil procedural law on those legal relations that arise, change and terminate in civil proceedings. In general, such a definition is fully consistent with the conclusions we have drawn earlier in this paper, since the essence of the mechanism of legal regulation of civil procedural relations according to such a concept is fully consistent with the essence of the mechanism of legal regulation in general, but with sectoral features. Thus, an understanding of the mechanism of legal regulation of civil procedural relations can be expressed in the following provisions: 1) the mechanism is a set of complex, interdependent procedural remedies; 2) these elements are characterized by systemic and interdependent features, that is, they are interconnected, form a single whole,

${ }^{2}$ Цивільний процес України : навчальний посібник / за ред. Ю. С. Червоного. К., 2006. 
united by a common purpose; 3) elements of the mechanism of legal regulation of civil procedural relations are a state instrument by which the effective influence of civil procedural law on civil procedural relations is ensured. That is, in general, this definition can be explained as being identical to general theoretical concepts, taking into account industry specificities.

A.L. Pascar, exploring the mechanism of civil procedural regulation, clarifies that it is an element of the mechanism of general state legal regulation, which takes effect in the event of obstacles to legal regulation. On the one hand, it is an element of the general mechanism of legal regulation, and on the other - it is a relatively separate system with its own content, structure and functions.In such methodological approaches, the mechanism of civil procedural regulation can be regarded as a complex system, characterized by the theoretical basis of the conclusions drawn in the general theory of law regarding the concept of legal regulation, so to define the concept of "mechanism of civil procedural regulation" should be based on the concept of "mechanism of civil procedural regulation" regulation".

Therefore, given that, in general, the concept of the mechanism of civil procedural regulation was not actually established in the legal doctrine, we formulate a corresponding definition on the basis of previous general theoretical studies, but taking into account industry specificities.

The mechanism of civil procedural regulation is a system of complex, interrelated and united by common purpose procedural remedies, methods and forms that operate in a well-established and in constant connection and functioning of which is connected with the legal influence of the state on civil legal relations. in order to satisfy the public and private interests of the participants and to organize them.

The features of the mechanism of civil procedural regulation can be distinguished in the light of previous research and analysis of scientific literature.

1) the mechanism of civil procedural regulation is systemic and interdependent;

2) the mechanism of civil procedural regulation is purposeful and effective;

3) the combination of unity and differentiation in the mechanism of civil procedural regulation;

4) the effect of the mechanism of civil procedural regulation extends exclusively to the relations which are the subject of legal regulation;

5) the decisive role of the court in the mechanism of civil procedural regulation. 
The mechanism of civil procedural regulation as an element of the mechanism of legal regulation is also characterized by these features, however, taking into account the peculiarities of the field of civil procedural law, its subject and method.

The systemic nature is that the mechanism of civil procedural regulation consists of elements that interact in the process of legal regulation, ensuring the normal functioning of the whole mechanism of civil procedural law. These elements are interconnected, predictive of each other and act in concert. It should be noted that one of these elements is the civil procedural relationship.

The purposeful indication is that the mechanism of civil procedural regulation has the purpose of functioning, which, in particular, is set out in Article 2 of the CPC of Ukraine $^{3}$ - fair, impartial and timely consideration and resolution of civil cases in order to effectively protect violated, unrecognized or contested rights, freedoms or contested rights natural persons, rights and interests of legal entities, interests of the state. The "effectiveness" of the mechanism of civil procedural regulation in this context depends on whether the goals and objectives of justice have been achieved. Ineffective protection of violated, unrecognized or contested rights, freedoms or interests of individuals, rights and interests of legal entities, interests of the state indicates the need to improve civil procedural legislation.

The next feature is related to the legal nature of the mechanism of civil procedural regulation. As A. AL notes. Pascar, it has a dual nature, which is a combination of unity and differentiation' ${ }^{4}$. The unity of the mechanism of civil procedural regulation is ensured by establishing uniform procedures for the administration of justice in civil cases, defined by the law of the limits of judicial discretion, unity of civil procedural legislation, etc. It is worth agreeing with this explanation, and confirmation of it is the norms of the CPC of Ukraine. At the same time, a large number of civil cases, their differentiation by categories, by the specific circumstances of the case, the specifics of various situations that require individual settlement, the variety of legal facts, the differentiation of the procedure for opening proceedings in a particular case, etc. due to the peculiarities of the mechanism of civil procedural regulation. From all the above, we can conclude that there is a mechanism of civil procedural regulation of both unity and differentiation.

3 Цивільний процесуальний кодекс України: Закон України від 18.03.2004 № 1618-IV. Відомості Верховної Ради Украӥни. 2004. № 40-41, 42. Ст. 492.

4 Паскар А. Л. Роль механізму цивільного процесуального регулювання у забезпеченні ефективності цивільного судочинства. Приватне та публічне право. 2017. № 2. C. $37-40$. 
The character of the mechanism of civil procedural regulation extends exclusively to relations that are the subject of legal regulation and are derived from the nature of the investigated type of legal regulation mechanism. Since the mechanism of legal regulation includes a number of mechanisms that regulate certain spheres of public relations, the object of the mechanism of civil procedural regulation is exclusively public relations governed by the rules of civil procedural law. Therefore, the mechanism of civil procedural regulation includes the norms of the Constitution of Ukraine1, CPC of Ukraine 5 , Law of Ukraine "On Private International Law" of June 23, 2005 No. 2709-IV ${ }^{6}$, laws of Ukraine that determine the peculiarities of consideration of certain categories of cases, as well as international treaties the leniency of which is provided by the Verkhovna Rada of Ukraine, which respectively regulate public relations, which are the subject of its legal regulation.

The last feature highlighted by us is the decisive role of the court in the mechanism of civil procedural regulation. Although the rules of civil procedural law set out a number of rules for the functioning of the investigated mechanism (rules, principles, stages, requirements, etc.), however, only general limits of regulation are defined in this way. Accordingly, the main role in this process belongs to the court, which, in particular, in accordance with Article 12, paragraph 5 of the CPC of Ukraine $^{7}$, directs the course of the litigation, facilitates the settlement of the dispute by reaching an agreement between the parties, and clarifies their procedural rights and obligations, if necessary. consequences of committing or failing to act, contributes to the litigants in the exercise of their rights, prevents abuse of litigants' rights and takes measures to fulfill their responsibilities. That is, in the mechanism of civil procedural regulation, the general regulation is carried out by the rules of law, and the regulation taking into account the peculiarities of each specific relationship is exercised by the judge as their determining subject.

\section{Structural elements of the mechanism of civil procedural regulation}

Examining the mechanism of legal regulation, theorists of law point out that it has its own structure. However, as the analysis of the scientific literature indicates, the composition of the mechanism is not in all cases

5 Цивільний процесуальний кодекс України : Закон України від 18.03.2004 № 1618-IV. Відомості Верховної Ради України. 2004. № 40-41, 42. Ст. 492.

6 Про міжнародне приватне право: Закон України від 23.06.2005 № 2709-IV. Відомості Верховної Ради України. 2005. № 32. Ст. 422.

7 Цивільний процесуальний кодекс України : Закон України від 18.03.2004 № 1618-IV. Відомості Верховної Ради Украӥни. 2004. № 40-41, 42. Ст. 492. 
consistent between different researchers. Thus, one of the traditional concepts for this field is the concept proposed by S.S. Alekseev, who identified among the structural elements of the mechanism of legal regulation: 1) legal norms; 2) legal relations, namely: the subjective rights and legal obligations of the participant of such relations; 3) acts of realization of rights and obligations; 4) individual prescriptions and acts of application of law ${ }^{8}$. This concept is shared by other authors. Its structure is composed of elements that are at one level of legal regulation, exist and function only in interaction with others.

The concepts of scholars are quite common, distinguishing only three elements: 1) rules of law, which establish the general and legal binding rules of conduct for those participants in public relations who are in the field of legal regulation; 2) legal relations, which is the most important and necessary element of the real life of law; 3 ) acts of realization of legal rights and obligations - the actual behavior of the subjects of legal relations in the exercise of their rights and obligations. Let us pay attention to the following features of this position: first, its composition of elements fully corresponds to the elements proposed by S.S. Alexeev; secondly, legal relations stand out as the most important element among others; third, from the perspective of this researcher, individual prescriptions and acts of law are not part of the mechanism of legal regulation. In general terms, discussions are possible regarding the latter issue, however, in the field of civil legal regulation, the court is the decisive subject.

Accordingly, court decisions should be attributed to acts of law, because they are issued on the basis of legal facts and rules of law and determine the rights, obligations or measure of legal liability of individuals. Therefore, we conclude that with regard to the mechanism of civil procedural regulation, it is more appropriate to have a concept that provides for acts of law.

At the same time, some scholars distinguish another range of elements of the mechanism of legal regulation. For many scholars, the elemental structure of the mechanism of legal regulation of social relations is narrowed by the exclusion of elements of the legal relationship ${ }^{9}$, expanded by the introduction of additional components, such as legal consciousness, principles of law, legal facts, subjective legal rights and obligations, etc ${ }^{10}$. However, the previous concepts analyzed are still much more substantiated and more universal.

8 Алексеев С. С. Право: азбука - теория - философия. Опыт комплексного исследования. М.: Статут, 1999.

9 Лукьянова Е. Г. Механизм процессуального регулирования и его элементы. М. : Норма, 2001.

10 Заморська Л. І. Функції права: змістовно-теоретичний аналіз / Л. І. Заморська. Актуальні проблеми вітчизняної юриспруденції. 2015. Вип. 6. С. 3-9. 
From this we conclude that the only logical consistent theoretical construction of the mechanism of legal regulation in domestic theory is absent today. On this occasion S.V. Kimchynskaya notes that the presence of different approaches to the interpretation of the elementary set of the mechanism of legal regulation of social relations, on the one hand, indicates the complexity and multidimensionality of the phenomenon under study, and on the other hand - an indicator of the dynamics and development of legal science. In addition, let us look at another conclusion of the researcher despite the differences and contradictions of the concepts of the elemental composition of the mechanism of legal regulation, proposed by different scientists, the common feature of each selected component is that they are all either the result or the cause of human activity. Therefore, the researcher concludes that without the relevant subject of application, none of the elements can be implemented. With this in mind, the scientist proposes to supplement the list of elements of the mechanism of legal regulation of civil procedural relations with another element - the subject of legal realization, which in the aspect of the research institute is the court and other participants of the civil process ${ }^{11}$. Considering thatthe concept of SS is dominant in the national science. Alekseeva, let us conclude that the allocation of the elemental composition of the mechanism of civil procedural regulation should be made on the basis of its position, as well as the conclusions made by S.V. Kymchinskaya.

Therefore, we summarize the analysis performed by identifying the following elements of the civil procedural regulation mechanism, which are:

1) the subject of the right realization (above all the court, as well as the participants in the civil process);

2) rules of civil procedural law;

3) civil procedural legal relations;

4) acts of realization of rights and obligations (will of subjects of civil procedural relations);

5) acts of application of law (according to Article 258 of the CPC of Ukraine $^{12}$, judicial acts of application of law are decisions, decisions, decisions, court orders).

In the implementation of the mechanism of civil procedural regulation, the subject of legal realization is the element with which civil procedural relations are of primary importance, since the parties are an obligatory

11 Кімчинська С. В. Суб'єктний склад механізму цивільного процесуального регулювання. Науковий вісник Чернівецького національного університету. 2013. Вип. 714. С. 78-82.

12 Цивільний процесуальний кодекс України : Закон України від 18.03.2004 № 1618-IV. Відомості Верховної Ради Украӥни. 2004. № 40-41, 42. Ст. 492. 
element of any legal relationship. The substantive composition of the mechanism of civil procedural regulation has already been established by us in this work. It consists of the following elements:

1) parties to the case - parties (natural and legal persons as well as the state), third parties, in criminal proceedings the applicant and the debtor, in the cases of separate proceedings the parties to the proceedings are the applicants, bodies and persons to whom the law has the right to go to court for interests other persons (bodies of state power, bodies of local selfgovernment, Ombudsman of Ukraine), prosecutor, representatives;

2) other participants in the trial - Assistant Judge, Registrar, Attorney, Witness, Expert, Law Expert, Translator, Specialist;

3 ) the court as an indispensable participant in civil procedural legal relations - a judge alone; a collegiate court composed of one judge and two jurors; a three-judge panel of appeal judges; a panel of judges of the court of cassation of three or more odd judges; Grand Chamber of the Supreme Court.

Civil procedural relations and subjects of legal realization as elements of the mechanism of civil procedural regulation are interrelated, and their relationship is primarily that civil procedural relations arise in the course of consideration and settlement of a specific case due to the will of one of the parties. In this case, the participants in the case are involved in a voluntary or coercive mechanism, and the participation of the court and other participants in the trial is the realization of their right to work and duties.

In other words, the acts of realization of rights and duties as elements of the mechanism of civil procedural regulation are the will of the subjects of civil procedural relations, expressed in this context mainly in a documentary form, which consists in the exercise by such persons in accordance with the rules of civil procedural law of their capabilities, performance. obligations or compliance with injunctions that have legal consequences for them. Relation of the acts of realization of rights and obligations with the civil procedural obligations is first of all that they are the form according to which civil procedural relations arise or change.

Therefore, summarizing the study of the place of civil procedural relations in the mechanism of civil procedural regulation, we should draw the following conclusions: 1) civil procedural relations are an element of the mechanism of civil procedural regulation, without which its functioning is impossible; 2) civil procedural relations are related to other elements of the mechanism of civil procedural regulation as follows: a) the subject of legal proceedings is the element with which civil procedural relations are of primary importance, since the parties are an obligatory element of any legal relations; b) civil procedural relations arising in the course of consideration 
and settlement of a particular case are governed by the rules of civil procedural law; c) the connection between the acts of realization of rights and obligations as an element of the mechanism of civil procedural regulation with civil procedural relations is that they are the basis for their origin and change or termination; d) the acts of law are an element of the mechanism of civil procedural regulation, which causes the termination of civil procedural relations.

\section{Functions of civil procedural legal relations in the mechanism of civil procedural regulation}

The next question to be addressed is the function of civil procedural relations in the mechanism of civil procedural regulation. The concept of "function" in the theoretical sense is not exclusively legal. This term was first introduced into scientific circulation as mathematical, but later entered into legal terminological circulation.

The term "function of law" was first used in the nineteenth century in the work of German Roman law researcher R. Ehring, "The Spirit of Roman Law at Different Stages of Its Development," which argued that the function of law is its realization. Subsequently, this definition has undergone considerable transformation and refinement, but the main idea of the functions has been properly enshrined - functions are a form of influence of law. Subsequently, the issue of defining the functions of law was developed at the sectoral level, and new conceptual approaches to defining this concept emerged.

In encyclopedic sources, the concept of "function" is considered in two meanings: 1) as a phenomenon that depends on another phenomenon, acts as a form of its detection and changes in accordance with its changes; 2) as a job, a duty, a range of activities, etc. Of these two, the former is general and in no way related to legal theory. With regard to understanding a function as a phenomenon that is dependent on another phenomenon, acts as a form of its detection and changes according to its changes, then such a meaning can be correlated with the legal, if the term "phenomenon" means the concept of "right". In this case, the function is a phenomenon that depends on the law, acts as a form of its detection and changes according to its changes. Yes, indeed, the functions of civil procedural legal relations will change provided that changes are made to the existing civil procedural legislation, for example, the CPC of Ukraine.

Equally true is the assertion that function is a form of discovery of law, because by the use of functions, the effect of law is on certain legal relations. Therefore, we conclude that a general theoretical understanding of the 
concept of "function" may well underlie the special legal definitions. This is confirmed by the analysis of the scientific approaches of legal scholars.

Regarding the encyclopedic legal literature, in the Legal Encyclopedia, edited by Yu.S. Shemshchenk's functions are defined as "the directions or types of influence of law on social relations, by which the role and purpose of law in society and the state, its social value and the most important features are expressed"13. That is, characterizing the essence of functions, we should start from the following: 1) first of all, functions are the directions of influence of law, that is, how exactly law influences social relations; 2) the function expresses the role and purpose of law in society and the state, its social value and the most important features, namely: functions allow you to establish the role of law in regulating the relevant legal relations. In general, this approach is close to a theoretical understanding of the essence of functions from a legal point of view. Yes, functions are seen as directions or types of influence of law on public relations. That is, functions are indeed a manifestation of law that reflects its impact on public relations.

This understanding was formed in the classical theory of law, in which the authors at that time analyzed the concept of "function" in the context of the influence of law on the development of social relations. For example, Yu.G. Tkachenko viewed the functions of law as the specific role of law in organizing public relations ${ }^{14}$. This understanding is quite comparable to the understanding of the functions as directions of influence of law. That is, the influence of the right on social relations is exercised for the purpose of organizing them. The explanation of the essence of functions as a role of law is not quite accurate, but in general this model remains relevant to this day.

The notion of "function of civil procedural relations", as well as "function of legal relations", in general, are not characteristic of national science, so in formulating the appropriate definition, we will take the general theoretical concept, as well as formulated by us earlier definition of the concept of "civil procedural relations. Therefore, let us define the functions of civil procedural relations as the directions of influence of civil procedural law on public relations governed by the rules of civil procedural law arising in civil proceedings in order to ensure justice in the protection of violated, unrecognized or contested rights, freedoms or interests of physical persons, interests or interests persons, the interests of the state between the court as a compulsory subject, the persons involved in the case, and other participants

13 Юридична енциклопедія : в 6 т. / гол. ред.: Ю. С. Шемшученко, М. П. Зяблюк, В. Д. Горбатенко та ін. Т. 6: Т-Я. К. : Українська енциклопедія ім. М. П. Бажана, 2004.

14 Ткаченко Ю. Г. Методологические вопросы теории правоотношений. М. : Юридическая литература, 1980. 
in the civil process through which erred to the role and purpose of civil procedure law in society and the state, its social value and important features.

Thus, it has been established in the scientific literature that the problem of classification of functions of legal regulation is at the same time one of the essential problems of the theory of law. However, these functions are mainly regarded as subspecies of the regulatory function of law ${ }^{15}$. Thus, the regulatory function is one of the determining directions of the influence of law on social relations in the system of functions of law, and it can be defined as the direction of legal influence due to its social purpose, which is expressed in establishing positive rules of conduct, granting rights and imposing legal obligations on the sub of law. As it is noted in scientific works, the main forms in which the social function of the regulatory function, namely the regulation of social relations, manifests itself are: 1) whether it finds expression in the form of normative or enforceable acts; 2) whether it is carried out in general or specific legal relations; 3 ) whether it establishes the legal status, legal personality of citizens, or determines the competence of state bodies and legal entities ${ }^{16}$.

In general, there are three approaches to identifying sub-functions within a regulatory function within legal sources:

1. Selection of two elements - regulatory static and regulatory dynamic subfunctions;

2. Selection of three elements - regulatory static, regulatory dynamic subfunction and regulatory negative subfunction ${ }^{17}$;

3. Selection of a number of elements - for example, functions of ordering, guaranteeing, coordination and protection of interests, integrative, political, stabilizing, modeling, orienting, stimulating and limiting.

Of all these models, the first and the second are more traditional. Given that a negative subfunction of the regulatory function of legal regulation is to establish a prohibition of certain behavior, we note its inherent in civil procedural relations. Therefore, in the context of the topic of our study, a second model is more appropriate.

\footnotetext{
${ }^{15}$ Куракін О. М. Аналіз функцій правового регулювання в аспекті його ефективності. Науковий вісник “Держава та регіони”. 2016. № 2. С. 53-58.

${ }^{16}$ Тарахонич Т. І. Механізм дії права, механізм правового регулювання, механізм реалізації права: особливості взаємодії. Держава і право. Серія "Юридичні і політичні науки”. К. : Ін-т держави і права ім. В. М. Корецького НАН України, 2010. Вип. 50. C. $11-17$.

${ }^{17}$ Горшенев В. Н. Способы и организационные формы правового регулирования. М., 1972.
} 
Along with the regulatory function, traditionally, another function of law and legal relations - security. This opinion, in particular, is supported by Yu.S. Chervonyi, from which point of view, the protective function of civil procedural law is aimed at restoration of property and personal non-property rights, freedoms and legal interests of the subjects of law ${ }^{18}$. That is, the essence of this function lies in the fact that the subjects of civil procedural law enter into appropriate legal relations in order to restore property and personal non-property rights, freedoms and legitimate interests. Considering that civil procedural relations arise in civil proceedings for the purpose of ensuring justice in the protection of the violated, unrecognized or contested rights, freedoms or interests of individuals, rights and interests of legal entities, interests of the state, we conclude that they also exercise and protect.

On the other hand, the above list of functions does not take into account the specifics of civil procedural relations in the mechanism of civil procedural regulation. Therefore, we propose to distribute the functions of civil procedural legal relations in the mechanism of civil procedural regulation into general theoretical functions of civil procedural legal relations and special sectoral functions of civil procedural legal relations.

The general theoretical functions of civil procedural relations are related to the consolidation of existing civil procedural relations, the development of new ones, and the establishment of limits to the possible behavior of subjects. Special sectoral functions of civil procedural relations are aimed at providing the whole mechanism of civil procedural regulation, as well as regulating the behavior of participants in legal relations.

The general theoretical functions of civil procedural relations in the mechanism of civil procedural regulation are:

1) regulatory static function - is related to the consolidation of existing public relations;

2) regulatory dynamic function - related to the development of new social relations;

3) regulatory negative function - a ban on certain behavior is established $^{19}$;

4) security function - related to the restoration of property and personal non-property rights, freedoms and legitimate interests of legal entities ${ }^{20}$.

${ }^{18}$ Цивільний процес України : навчальний посібник / за ред. Ю. С. Червоного. К., 2006.

${ }^{19}$ Куракін О. М. Аналіз функцій правового регулювання в аспекті його ефективності. Науковий вісник “Держава та регіони”. 2016. № 2. С. 53-58.

${ }^{20}$ Цивільний процес України : навчальний посібник / за ред. Ю. С. Червоного. К., 2006. 
Special features of civil procedural legal relations in the mechanism of civil procedural regulation we propose to distinguish from the analysis of scientific literature. In this aspect, given the low level of attention of domestic researchers to this issue, let us first of all highlight the work of A.M. Pascar $^{21}$ and some law theorists9 whose work contributed to the selection of special sectoral functions of civil procedural relations in the mechanism of civil procedural regulation.

1) security function - the analysis of legal sources showed that the place of civil procedural relations in the mechanism of civil procedural regulation is not limited to the fact that they are an integral part of the latter;

2) nation-wide orientation function - in the general sense, the orientation function is that the subject, knowing the prescriptions of legal norms, himself builds his behavior in a lawful manner, which is the purpose of the state in determining patterns of lawful behavior;

3) individual orientation function - individual regulation is defined as the solution of specific problems based on the rules of law. S.S. Alexeyev ${ }^{22}$ explains individual regulation by the fact that no norm is able to cover the whole set of legal facts and to take into account all the peculiarities of situations that cause the law to be applied, and therefore it makes it necessary to allow the legislator to regulate legal relations by the subjects themselves.

That is, having only a national orientation function is not sufficient for a mechanism of civil procedural regulation, and the implementation of such provisions is important. The court, entering into the relevant legal relations, continues to regulate them with the help of acts of law. However, at the scientific level, it is noted that in the field of civil procedural law, legal regulation cannot begin to exert its influence without individual regulation, since it is the court that establishes the connection between the rule of law and the specific situation, thereby triggering the rules of civil procedural law.

\section{CONCLUSIONS}

Thus, having examined the place and functions of civil procedural legal relations in the mechanism of civil procedural regulation, it should be noted that this institute is one of the key for the whole system under study. On the

21 Паскар А. Л. Місце цивільних процесуальних правовідносин у механізмі цивільного процесуального регулювання. Науковий вісник Чернівецького університету. 2012. Вип. 618. С. 82-88.

22 Проблемы теории государства и права : допущено Министерством высшего и среднего специального образования СССР в качестве учебника для студентов вузов, обучающихся по специальности "Правоведение" / [C. С. Алексеев, И. Я. Дюрягин, В. Б. Исаков и др.] ; под ред. С. С. Алексеева. М. : Юрид. лит., 1987. 
one hand, it should be noted that each of the elements selected by us is mandatory for the mechanism, so the absence of any of them makes it impossible to operate. Civil procedural relationships, on the other hand, are the one component that brings together all the other elements around them. Therefore, when correlating civil procedural relations with other elements of the mechanism of civil procedural regulation, it is worth noting the close relationship of each of them, as well as the primary role of the investigated component.

\section{SUMMARY}

The article deals with the analysis of the place and functions of civil procedural relations. The author emphasizes that in the mechanism of civil procedural regulation can undergo significant changes both from the point of view of the organization (for example, by expanding the scope of civil jurisdiction), and from the point of view of changing the scope of rights and obligations of subjects of civil procedural regulation in the process of improvement relevant legal institutions.

The author examines the place and functions of civil procedural relations in the mechanism of civil procedural regulation. Many of the studies we analyzed were carried out many years ago, and the development of public relations and legislation in our country is permanent, which makes the actual implementation of this research.

The author analyzes the main feature of the functions and the general theoretical functions of civil procedural relations in the mechanism of civil procedural regulation. The author emphasizes the peculiarities of civil procedural relations in the mechanism of civil procedural regulation.

\section{REFERENCES}

1. Конституція України : Закон України від 28 черв. 1996 р. Відом. Верхов. Ради України. 1996. № 30. Ст. 141.

2. Цивільний процесуальний кодекс України : Закон України від 18.03.2004 № 1618-IV. Відомості Верховної Ради Украйни. 2004. № 40-41, 42. Ст. 492.

3. Про міжнародне приватне право : Закон України від 23.06.2005 № 2709-IV. Відомості Верховної Ради Украӥни. 2005. № 32. Ст. 422

4. Алексеев С. С. Право: азбука - теория - философия. Опыт комплексного исследования. М.: Статут, 1999. 712 с.

5. Великий тлумачний словник сучасної української мови (з дод. і допов.) / уклад. і голов. ред. В. Т. Бусел. К.; Ірпінь : ВТФ “Перун”, 2005. $1728 \mathrm{c}$. 
6. Гончарук С. Т. Адміністративне право України : навч. посіб. К. : Генеза, 2000. 240 c.

7. Горшенев В. Н. Способы и организационные формы правового регулирования. М., 1972. 153 с.

8. Діденко Л. В. Функції цивільних процесуальних відносин у механізмі цивільного процесуального регулювання. Науковий вісник публічного та приватного права: зб. наук. пр. Київ, 2017. Вип. 6. Т. 4. C. 39-45.

9. Загальна теорія держави і права : підручник для студентів юридичних вищих навчальних закладів / М. В. Цвік, О.В.Петришин, Л. В. Авраменко та ін.; за ред. д-ра юрид. наук, проф., акад. АПрН України М. В. Цвіка, д-ра юрид. наук, проф., акад. АПрН України О. В. Петришина. Харків : Право, 2009. 584 с.

10. Заморська Л. І. Функції права: змістовно-теоретичний аналіз / Л. І. Заморська. Актуальні проблеми вітчизняної юриспруденції. 2015. Вип. 6. С. 3-9.

11.Иеринг Р. Дух римского права на различных ступенях его развития / пер. с 3-го исправл. нем. изд. СПб. : Тип. В. Безобразова и Ко, 1875. Ч. 1. $321 \mathrm{c.}$

12. Кельман М. С., Мурашин О. Г. Загальна теорія держави і права : підручник. К. : Кондор, 2006. 477 с.

13. Кімчинська С. В. Суб'єктний склад механізму цивільного процесуального регулювання. Науковий вісник Чернівецького національного університету. 2013. Вип. 714. С. 78-82.

14. Куракін О. М. Аналіз функцій правового регулювання в аспекті його ефективності. Науковий вісник “Держава та регіони”. 2016. № 2. C. 53-58.

15. Лазарев В. В., Липень С. В. Теория государства и права : учебник. 3-е изд., перераб. и доп. М. : Спарк, 2004. 528 с.

16. Лукьянова Е. Г. Механизм процессуального регулирования и его элементы. М. : Норма, 2001. 106 с.

17. Паскар А. Л. Місце цивільних процесуальних правовідносин у механізмі цивільного процесуального регулювання. Науковий вісник Чернівецького університету. 2012. Вип. 618. С. 82-88.

18. Паскар А. Л. Роль механізму цивільного процесуального регулювання у забезпеченні ефективності цивільного судочинства. Приватне та публічне право. 2017. № 2. С. 37-40.

19.Проблемы теории государства и права : допущено Министерством высшего и среднего специального образования СССР в качестве учебника для студентов вузов, обучающихся по специальности "Правоведение" / [С. С. Алексеев, И. Я. Дюрягин, 
В. Б. Исаков и др.] ; под ред. С. С. Алексеева. М. : Юрид. лит., 1987. $448 \mathrm{c.}$

20. Скакун О. Ф. Теорія держави і права : підруч. Х. : Консум, 2008. $656 \mathrm{c}$.

21. Словник української мови : в 11 т. / за ред. І. К. Білодіда, А. А. Бурячок та ін. Т. 10. К. : Наукова думка, 1979. 657 с.

22. Тарахонич T. I. Механізм дії права, механізм правового регулювання, механізм реалізації права: особливості взаємодії. Держава і право. Серія “Юридичні $i$ політичні науки”. К. : Ін-т держави і права ім. В. М. Корецького НАН України, 2010. Вип. 50. C. 11-17.

23. Теория государства и права : учебник / под ред. С. С. Алексеева. М. : Норма, 2004. 496 c.

24. Ткаченко Ю. Г. Методологические вопросы теории правоотношений. М. : Юридическая литература, 1980. 176 с.

25. Цивільний процес України : навчальний посібник / за ред. Ю. С. Червоного. К., 2006. 392 с.

26. Юридична енциклопедія : в 6 т. / гол. ред.: Ю. С. Шемшученко, М. П. Зяблюк, В. Д. Горбатенко та ін. Т. 6: Т-Я. К. : Українська енциклопедія ім. М. П. Бажана, 2004. 768 с.

\section{Information about the author: Didenko L. V.,} $\mathrm{PhD}$, Associate Professor at the Department of Civil and Economic Law and Procedure, International Humanitarian University 33, Fontanska Road str., Odessa, 65009, Ukraine 


\section{REGULATION OF FREEDOM OF ACCESS TO ENVIRONMENTAL INFORMATION IN THE LEGISLATION OF THE EUROPEAN UNION AND UKRAINE}

\section{Kachuriner V. L.}

\section{INTRODUCTION}

In the 21st century, mankind faced specific threats to the environment due to air, water and soil pollution, reduced species biodiversity and climate change. These trends contribute to the creation of an appropriate legal framework and to greater accountability for environmental pollution. Thus, environmental protection has become the subject of numerous national, supranational and international legal norms. In addition, international environmental activities cannot be considered separately from related economic issues and social problems. Environmental protection is now a key issue on the political agenda and an important problem, both at national and European and international levels.

The global nature of environmental problems necessitates the further development of international environmental law as a legal basis for international environmental cooperation. Environmental concepts, standards and principles are usually specified in regional and bilateral agreements, and detailed regulation is carried out at national level, as appropriate. However, European Union law has a particularly significant impact on both international and national environmental law. The most intensive national and international regulation of environmental protection is carried out on the European continent, and the most successful environmental problem is solved in the context of European integration. This is evidenced by the legal experience of implementing environmental policy at both the European Union and Member States level.

Environmental protection is one of the priority areas of the European Union's activities, which defines the EU's competence in the field of environmental protection and causes the adoption of a large number of panEuropean regulations. The development of European environmental law is characterized by the search for optimal approaches to solving complex problems of natural resource management. Thus, in the Association Agreement between Ukraine and the European Union, Article 360-366 of 
Section V, "Economic and Sectoral Cooperation"1, is devoted to the environment itself. The Parties to the Agreement cooperate on environmental issues and thus contribute to the achievement of the goals of sustainable development and the "green economy". Analysis of EU environmental legislation is essential to further improve and improve the effectiveness of environmental legislation in Ukraine. The priority of Ukraine's cooperation with the European Union will be of practical importance - achieving the goal of improving the level of production productivity, expanding its base of economic growth and competitiveness, studying and introducing experience and basic developments in the field of environmental human rights and citizens. It is advisable to draw attention to the various doctrinal developments in the field of protection of environmental human rights, both in general in the EU legal system and in respect of a particular type of rights, the right to access environmental information.

In recent years, many EU environmental law researchers have put on the agenda the question of whether national laws of EU Member States, as well as EU unified law, have sufficient legal basis to protect the interests of society against the dangers of environmental problems, or to seek additional guarantees of respect for the fundamental right of the individual - the right to a clean environment.

\section{The principle of access to environmental information in international law}

The interdependence of environmental protection, peace, human rights and freedoms was first reflected in the Stockholm Declaration of $1972^{2}$. This principle was subsequently developed and substantially supplemented in other international instruments. In particular, the next step in the development of citizens' environmental rights in international law was the UN Conference on Environment and Development, held in June 1992 in Rio de Janeiro, which adopted a number of important international instruments ${ }^{3}$, in including the Declaration and Agenda for the 21st Century. The 21st

\footnotetext{
${ }^{1}$ Угода про асоціацію між Україною, з однієї сторони, та Європейським Союзом, Європейським Співтовариством з атомної енергії і їхніми державами-членами, з іншої сторони. URL: http://www.kmu.gov.ua/control/publish/article?art_id=246581344

2 Декларация Конференции Организации Объединенных Наций по проблемам окружающей человека среды 1972 г. URL: http://www.un.org/ru/documents/decl_conv/ declarations/declarathenv.shtml

${ }^{3}$ Доклад Конференции Организации Объединенных Наций по окружающей среде и развитию Рио-де-Жанейро, 3-14 июня 1992 года A/CONF.151/26/Rev.1 (Vol. I). НьюЙорк : Организация Объединенных Наций. 1993. С. 7-8.
} 
Century Agenda, which is the plan of action of the International Community for Environment and Sustainable Development, states that environmental issues are addressed with the participation of all concerned citizens. States contribute to informing society by providing widespread access to environmental information. At the 3rd Sofia Conference of Ministers of the Environment of Europe in 1995, guidelines for access to environmental information were adopted. In June 1998, at the 4th Conference of Ministers of the Environment, held in Aarhus (Denmark), 35 countries of Europe signed the Convention on Access to Information, Public Participation in Decision-making and Access to Justice in Environmental Matters ${ }^{4}$ which was subsequently ratified by both the European Union and Ukraine, and therefore a further analysis of the provisions of this Convention is common to both the EU and Ukraine. Paragraph 3 of Art. 2 of the Aarhus Convention lists the information that should be considered environmental. So, this is information about: the state of the components of the environment and their interaction: the state of the atmosphere and the air, the state of water, the state of the soil, the state of landscapes, the state of natural objects, biological diversity and its components, including genetically modified organisms; factors that influence or are capable of affecting the components of the environment: substances, energy, noise, radiation; activities that affect or may affect environmental components; measures that affect or may affect environmental components: administrative measures, environmental agreements, environmental policy, legislation, plans, programs, justifications for environmental decisions; cost-benefit analysis and other economic analysis and assumptions used in the environmental decision-making process; the state of health and safety of people, living conditions, the state of objects of culture and structures to the extent that they are affected or may be affected by the state of the environmental components ${ }^{5}$.

On 17 February 2005, the Council of the European Union signed the Decision $^{6}$ which adopted the Aarhus Convention. The convention is based on the assertion that better awareness and involvement of the public in

4 Конвенція ООН про доступ до інформації, участь громадськості в процесі прийняття рішень та доступ до правосуддя з питань, що стосуються довкілля (Орхуська Конвенція): Міжнародний документ від 25.06.1998. URL: http://www.unece.org (ECE/CEP/43).

5 Правове регулювання відносин в сфері довкілля в Європейському Союзі та в Україні / За заг. ред. В. Г. Дідика. К., 2007. С. 98.

${ }^{6}$ Council Decision 2005/370 of 17 February 2005 on the conclusion, on behalf of the European Community, of the Convention on access to information, public participation in decision-making and access to justice in environmental matters Convention on access to information, public participation in decision-making and access to justice in environmental matters. Official Journal. 2005. L 124. P. 1-20. 
environmental issues will help to strengthen the environment. The purpose of the Convention is to promote the protection of every person of the present and future generations to live in an environment conducive to health and well-being. By signing the Convention, its Parties have declared that each Party guarantees the right to access to information, to public participation in decision-making and to access to justice in environmental matters, without discrimination on grounds of nationality, nationality or place of residence, and in the case of a legal person, without discrimination on the basis of its registered location or actual center of business.

Drawing on the main provisions of the Aarhus Convention, we can conclude that the Convention is based on three fundamental principles that are closely related.

1. The principle of access to environmental information. The Convention gives a broad concept of environmental information that covers not only the state of environmental components such as air, water, soil, landscape, biological species, including genetically modified organisms; but also such factors as energy, noise and radiation, as well as activities or activities, including administrative measures, environmental agreements, policies, legislation, plans and programs that affect or may affect environmental components, economic analysis data; health and safety of people, their living conditions; the status of cultural objects to the extent that they are or may be affected by the state of the environment. It is important that the information can be obtained without justification for the interest of having it, and in the form in which it is requested, and as soon as possible, but no later than four weeks. The applicant should be informed of any extension of the deadlines and the reasons for this. The Convention sets out the grounds for refusing to provide information, including the obviousness of the unreasonableness or non-formulation of the request and/or incompleteness of the requested material. A request for environmental information may also be refused if its disclosure could adversely affect the confidentiality of public authorities, international relations, national defense or public security, the administration of justice, the confidentiality of commercial and industrial information, personal data, intellectual property rights, etc. Information on harmful emissions into the environment may not be confidential. In cases where there is a threat to the environment or human health as a result of its activities or due to natural phenomena, all information that could enable the public to take measures to prevent or reduce harm should be disseminated immediately. States should ensure that public authorities have at their disposal environmental information pertaining to their type of activity and that mandatory systems are in place to ensure that public authorities receive appropriate information on planned and 
implemented activities that could have a significant environmental impact. Parties to the Convention should organize lists, registers or archives, and provide free access to the public. Each of the countries that have acceded to the Convention should ensure a gradual increase of information in electronic databases, which should be easily accessible to the general public. In accordance with the provisions of the Convention, information available through public communications networks to the general public should include, inter alia: environmental reports, texts of environmental legislation, policy documents, plans and programs, related to the environment or related environmental protection agreements and other information that may facilitate the application of national law to comply with the provisions of the Convention.

2. The principle of public participation in decision-making. The concerned public should be adequately, timely and effectively informed of environmental decisions of the authorities. In particular, under the Convention, it is information on the type of activity to be decided, the nature of such decisions, the procedure, time and place of their adoption, as well as the public authority responsible for decision-making and, most importantly, the possibility of public participation in making the above decisions. However, in order to ensure the most effective public participation in the environmental decision-making process, the provisions of the Convention provide for the need to provide the public with sufficient information for the time being. With regard to public participation in decision-making on specific activities that have or may have an environmental impact, it should be noted that under the Convention, the public authorities of each Party, in accordance with national law, provide the public concerned with free access to all information regarding a particular question. The Convention also provides a list of components that should include such information, including a description of the industrial site, a description of the most significant environmental factors, a description of measures to prevent or reduce such an impact, consideration of the main alternatives considered by the applicant and more. The Annex to the Convention provides a list of activities that may affect the environment and which the public has the right to participate in. The public participation process gives her the opportunity, during open hearings or consideration of such matters, to comment and to comment in writing or otherwise. In doing so, each country, in accordance with the provisions of the Convention, provides the conditions under which the results of public participation would be duly taken into account in the decision. Particular attention should be paid to the fact that, under the Convention, it is possible for the public to participate in the preparation of executive acts and/or generally binding legal acts that can significantly 
affect the environment. In order to ensure this, the most important is among other activities, namely, the public is given the opportunity to express their comments directly or through representative advisory bodies. The results of public participation are taken into account as much as possible.

3. The principle of access to justice. Any citizen who believes that his or her right to information or to participate in the decision-making process has been violated may challenge the decision in a court or other independent and impartial body. The Convention requires that the review of the decision in court be expeditious and would not require payment or that such payment would be low. Decisions taken by the court are binding on the public authority that has the relevant information. Relevant representatives of the concerned public who are either sufficiently interested or believe that a violation has occurred have access to justice. The presence of interest, as the suitability of public organizations to certain criteria, is determined in accordance with national law. However, the aforementioned provisions of the Convention do not preclude the use of a preliminary dispute settlement procedure by an appropriate administrative authority where such procedure is provided for in national law. States Parties to the Convention must provide effective remedies, including injunctive relief, fair, impartial, timely and cost-free ${ }^{7}$. The Convention declared that the parties should consider establishing mechanisms to eliminate or mitigate financial and other obstacles to justice. Such mechanisms are the least prepared for implementation in Ukraine. Undoubtedly, the Aarhus Convention today is the most important document that aims at securing and realizing the environmental rights of everyone. However, it should be noted that the first steps towards the adoption of important regulations in the field of environmental rights protection, in particular the right of access to environmental information, which is now the first of the principles on which the Aarhus Convention is based, were implemented by the European Union long before the Convention was approved.

\section{The right to access environmental information in EU legislation}

Directive 2003/4/EC was signed in order to provide the parties with a single, clear and comprehensive legislative text regarding public access to environmental information. In addition, it was declared that the provisions of the Directive should comply with the Aarhus Convention in connection with the signing of the latter by the European Community.

${ }^{7}$ Добробог Л.М. Інформаційне забезпечення реалізації прав людини на екологічну безпеку. URL: http://www-history.univer.kharkov.ua. 
The purpose of Directive 2003/4/EC is to guarantee the right of access to environmental information and to ensure the systematic and broadening of the boundaries of dissemination of environmental information to the public ${ }^{8}$. For this purpose, the Directive provides for the use of computer telecommunications and / or electronic technologies. To this end, States Parties shall take all necessary measures to ensure that public authorities have access to environmental information and to further disseminate such information through computer telecommunications and / or electronic technology, if available. According to the Directive, the information to be made available is, in particular: the texts of international agreements, conventions and agreements of the Community, national, regional and local legislation in the field of the environment; public policies, programs and plans for the environment; State reports on the state of the environment (to be published at least every 4 years); data on actions that affect the environment and more.

In accordance with the provisions of Directive 2003/4/EC, Member States should guarantee the accessibility and openness of environmental information held by a public authority or a public authority to any person requesting it. In this case, the requesting person does not need to formulate his/her interest. In order to comply with the guarantees above, the Parties are obliged to ensure that: officials support the public in accessing information; the list of public authorities was made available to the general public; practical measures have been identified to enable the effective exercise of the right of access to environmental information. Some innovation is that Member States ensure that public authorities properly inform the public about the rights they enjoy under this Directive and provide information and advice to that effect. However, Directive 2003/4/EC provides that, where the request is very broadly formulated, the public authority asks the person to clarify the request and helps him to do so, in particular by providing information on the use of public registers. The Directive provides for cases where requests for environmental information may be rejected, which generally comply with the provisions of the Aarhus Convention. At the same time, it is noted that in each case, public authorities should compare the public interest in disclosure and the interest that is the basis for refusal (to set priorities). The directive prohibits the rejection of a request if it is related to environmental information.

\footnotetext{
${ }^{8}$ Directive 2003/4/EC of the European Parliament and of the Council of 28 January 2003 on public access to environmental information and repealing Council Directive 90/313/EEC. Official Journal. 2003. L 041. P. 26-32.
} 
As regards the payment of environmental information, the Directive provides that the relevant public authorities may impose a fee for the provision of any information, but such a fee should not exceed a reasonable amount. At the same time, the rates of such payment should be published, as well as information on the conditions under which the fee may be charged. Much of Directive 2003/4/EC is devoted to one of the three fundamental principles on which the Aarhus Convention is based, namely, the principle of "public access to justice". In accordance with the provisions of the Directive, Member States shall ensure that any requesting person who considers that his or her request for information has been ignored, for which the request was incorrectly rejected (in whole or in part), or received or incorrectly answered the request was not considered in accordance with the provisions of the Directive, had access to a procedure for reviewing actions or omissions by this or other public authority or administrative review by an independent and impartial body established by law. The provisions of the Directive on the speed and free (moderation of payment) of such review are also fully in line with the Aarhus Convention. In addition to the review procedure, Member States should ensure that the requesting person has access to the review procedure by a court or any other independent and impartial body established by law, which may consider the actions or omissions of the relevant public authorities, and decisions of which may be final. In this case, the final decisions are binding on the executing public authority. Member States are also allowed to provide that third parties accused of disclosing information also have access to legal redress. Directive 2003/4/EC regulates the obligation for Member States to ensure that information is not outdated, accurate and comparable.

Case law already has 541 cases brought to light in the light of Directive 2003/4/EC . Computer telecommunications and / or electronic equipment are used for this purpose. L. Kremer points out that as of 2007, the European Court of Justice had issued around 400 decisions. He is trying to interpret modern environmental law ecologically friendly and to strengthen the environment ${ }^{10}$. In his work, A.L. Dubovyk gives a report to the judge of the

\footnotetext{
${ }^{9}$ Reference for a preliminary ruling from the Najvyšší súd Slovenskej republiky (Slovak Republic) lodged on 23 August 2010 - Jozef Križan and Others v Slovenská inšpekcia životného prostredia. Official Journal. 2010. C. 301. P. 11-12; Reference for a preliminary ruling from the Tribunal administratif de Paris (France) lodged on 12 November 2009 - Ville de Lyon v Caisse des dépôts et consignations. Official Journal. 2010. C. 37. P. 29; Request for a preliminary ruling from the Unabhängiger Verwaltungssenat Wien (Austria) lodged on 17 June 2013 - Ferdinand Stefan. Official Journal. 2013. C. 274. P. 2-3.

10 Кремер Л., Винтер Г. Экологическое право Европейского Союзу/ отв. ред. О. Л. Дубовик. М. : Городец, 2007. С. 40.
} 
Belgian Constitutional Court, L. Lavriesen, whom he delivered at a conference entitled "30 Years of EU Environmental Law" and emphasized that: "In the years of its activity, the Court of Justice has developed a series of general doctrines that have fostered efficiency. European law in general. These doctrines are also important for the development of environmental European law"11. However, in its decisions it establishes only the right, or more precisely, the competence of Union bodies to regulate any sphere, until the obligation to take measures based on the principles and aspects of environmental policy has been established in court. However, it is necessary to interpret the contents of these general provisions with some caution, since only the core of this program of obligations is protected by judicial protection. Anything that goes beyond this is subject to the legislature. L. Lavriesen emphasizes: "Since 7 February 1985, when the judgment in the L'Association de defense de brulenrs d huiles usages was decided, the Court recognizes that environmental protection is a "mandate requirement" which, in the absence of full harmonization legislation may justify the use of measures restricting trade in Member States"12.

Directive 2003/35/EC promotes the providing for public participation in respect of the drawing up of certain plans and programmes relating to the environment and amending with regard to public participation and access to justice $^{13}$. Member States shall enable the public to participate in the preparation and modification, revision of plans or programs. To this end, the following should be ensured: informing the public, either by public announcement or by other appropriate means, of such plans or programs; the public has the right to comment and decide on plans and programs; in making these decisions, due account should be taken of the results of public participation; having considered the comments and opinions expressed by the public, the competent authority shall use its best endeavors to inform the public of the decision and the reasons and considerations on which these decisions are based, including information on the public participation process.

Undoubtedly, the layer of EU uniform legislation on the protection of environmental information rights is much wider. However, the directives

11 Дубовик О.Л. Экологическое право ЕС: формирование, развитие, достижения и актуальные задачи. Право и политика. 2004. № 12. С. 65.

${ }^{12}$ Степаненко В.С. Понятие и правовое значение принципов экологической политики ЕС. Политика и общество : Научный гуманитарный журнал. 2006. № 6. С. 91-92.

${ }^{13}$ Directive 2003/35/EC of the European Parliament and of the Council of 26 May 2003 providing for public participation in respect of the drawing up of certain plans and programmes relating to the environment and amending with regard to public participation and access to justice Council Directives 85/337/EEC and 96/61/EC - Statement by the Commission. Official Journal. 2003. L 156. P. 17-25. 
mentioned are groundbreaking, because they laid the foundations for further development of EU law in this area.

\section{Legislation of Ukraine in the field of access to environmental information}

Regarding the legislative and regulatory acts of Ukraine governing the legal relations in the field of access to environmental information such as the Constitution of Ukraine, the Law of Ukraine "On Information" 14 of 02.10.1992, the Law of Ukraine "On Environmental Protection" 15 of 25.06.1991, Law of Ukraine "Fundamentals of Legislation on Health Care"16 of 19.11.1992, Law of Ukraine "On Ensuring Sanitary and Epidemic WellBeing of the Population"17 of 24.02.1994., Law of Ukraine "On Nuclear Energy Use and Radiation Safety"18 vi 02/02/1995, Law of Ukraine "On Ratification of the Convention on Access to Information, Public Participation in Decision-Making and Access to Justice in Environmental Matters" ${ }^{19}$ of 06.07.1999, Law of Ukraine "On Environmental Expertise"20 dated 9 February 1995 and others.

Environmental information plays a leading role in environmental security. First of all, such information is necessary for the preparation and adoption of economic, management and other decisions, the implementation of which is associated with the negative impact of human activity on the environment. Environmental information can be used by citizens to protect their environmental rights, as well as a basis for interfering with unsatisfactory environmental activities of the state, business structures, especially if the latter do not fulfill the tasks assigned to them by law. In Ukraine, the definition of "information" is enshrined in a number of legislative acts. However, the most general definition covering all types of information is provided in the Law of

${ }^{14}$ Про інформацію : Закон України від 02.10.1992 № 2657-ХІІ. Відомості Верховної Ради Украӥни. 1992. № 48. Ст. 650.

15 Про охорону навколишнього природного середовища: Закон від 25.06.1991 № 1264-ХІІ. Відомості Верховної Ради Украӥни. 1991. № 41. Ст. 546.

16 Основи законодавства України про охорону здоров'я: Закон від 19.11.1992 № 2801-XII. Відомості Верховної Ради Украӥни. 1993. № 4. Ст. 19.

${ }^{17}$ Про забезпечення санітарного та епідемічного благополуччя населення : Закон від 24.02.1994 № 4004-XII. Відомості Верховної Ради України. 1994. № 27. Ст. 218.

${ }^{18}$ Про використання ядерної енергії та радіаційну безпеку: Закон від 08.02.1995 № 39/95-ВР. Відомості Верховної Ради України. 1995. № 12. Ст. 81.

19 Про ратифікацію Конвенції про доступ до інформації, участь громадськості в процесі прийняття рішень та доступ до правосуддя з питань, що стосуються довкілля : Закон України від 6 липня 1999 року № 832-XIV. Офіційний вісник Украӥни. 1999. № 28. Ст. 2.

${ }^{20}$ Про екологічну експертизу : Закон від 09.02.1995 № 45/95-ВР. Відомості Верховної Ради Украӥни. 1995. № 8. Ст. 54. 
Ukraine "On Information". According to this Law, information is the documented or publicly announced information about events and phenomena occurring in society and the state and the environment. The classification of information at the legislative level is also enshrined in the Law of Ukraine "On Information", which refers not only to types of information but also to its industry. Article 3 of the aforementioned law establishes the obligation of the state to constantly ensure the timely creation, proper functioning and development of information systems, networks, banks and databases in all areas of information activities, which fully complies with the obligation established by Directive 2003/4/EC ${ }^{21}$. Member States shall take all necessary measures to ensure that the relevant public authorities have access to the information and that such information is systematic, accurate and up-to-date. The state guarantees freedom of information activities in these areas to all citizens and legal entities within the limits of their rights and freedoms, functions and powers. In general, the country has a well-developed system of regulations on the collection, accumulation, dissemination and access to environmental information. Among these are, in particular, the Law of Ukraine "Fundamentals of Healthcare Legislation",2, since environmental status is known to be an important factor affecting human health. The Law stipulates that one of the main means of ensuring the right of citizens to health protection from adverse environmental impact is the right of a person to have accurate and timely information about the state of their health and the health of the population, including existing or possible risk factors and their degree.

All the above-mentioned provisions of the Acts implement the principle of the Aarhus Convention on Public Access to Environmental Information, and also comply with the provisions of a number of EU Directives. However, the most important and substantive rules on the subject under investigation are usually contained in the Constitution of Ukraine. The constitutional norm of part two of Art. $34^{23}$, which enshrines the right to information, includes the ability to collect, store, use and disseminate any information orally, in writing or otherwise, at its discretion. Another provision of the Constitution of Ukraine enshrines the right of everyone to free access to information on the state of the environment, the quality of food and household goods, as well as the right to disseminate such

${ }^{21}$ Directive 2003/4/EC of the European Parliament and of the Council of 28 January 2003 on public access to environmental information and repealing Council Directive 90/313/EEC. Official Journal. 2003. L 041. P. 26-32.

22 Основи законодавства України про охорону здоров'я: Закон від 19.11.1992 № 2801-ХІІ. Відомості Верховної Ради Украӥни. 1993. № 4. Ст. 19.

${ }^{23}$ Конституція України : Закон від 28.06.1996 № 254к/96-ВР. Відомості Верховної Ради Украӥни. 1996. № 30. Ст. 141. 
information. The above information cannot be kept secret by anyone. This fully complies with the basic principles underlying EU legislation on access to environmental information, in particular the purpose of Directive 2003/4/EC. Based on Part 2 of Art. 50 of the Constitution, the right to access environmental information has three elements: it is the right to access information on the state of the environment, on the quality of food and household goods.

Information on the state of the environment is environmental information. The legislator, in adhering to this position, identifies the concepts of "information on the state of the environment" and "environmental information". On the one hand, there is a ban on taking certain actions on environmental information, on the other - there is a need to respect this right by any natural or legal person, as well as the state. Considering that the Constitution of Ukraine has the highest legal force, and laws and other legal acts are adopted on its basis and must comply with it, it can be argued that the provisions of the legislation of Ukraine, which set restrictions on access of citizens to environmental information, are unconstitutional $^{24}$. A characteristic feature of the right of access to environmental information, which distinguishes it from general information rights, is precisely the third element that excludes, under normal conditions, restrictions on environmental information. However, in conditions of martial law or emergency, in accordance with Part 2 of Art. 64 of the Constitution of Ukraine, individual restrictions on rights and freedoms may be established with an indication of the duration of these restrictions. The content of the above constitutional norms was reflected by the legislator even before the adoption of the basic law of Ukraine in the Law "On Environmental Protection". In particular, the provisions of this Law enshrined, among the basic principles of environmental protection, publicity and democracy in decision making, the implementation of which affects the state of the environment and the formation of ecological outlook among the population. Article 9 of the $\mathrm{Law}^{25}$ enshrines the right of every citizen to have free access to information on the state of the environment (environmental information) and the free receipt, use, dissemination and storage of such information, with the exception of restrictions established by law; the right to participate in public environmental expertise, to obtain environmental education.

Publicly available information - any environmental information, with the exception of special environmental information, in turn, specific

${ }^{24}$ Бойченюк I. Екологічна інформація та комерційна таємниця. Вісник екологічної адвокатури. 2006. № 30. С. 12-16.

25 Про охорону навколишнього природного середовища: Закон від 25.06.1991 № 1264-XII. Відомості Верховної Ради України. 1991. № 41. Ст. 546. 
environmental information includes data reflecting the specific activities of individual central sectoral public authorities dealing with defense and national security issues, as well as subject to trade secrets, confidentiality and other data which the right may be denied in accordance with the law. The principle of remuneration, which may be applied by the relevant authorities in providing environmental information, however, the fee charged for such information may not exceed the cost of copying, retrieving and preparing information in one form or another, which is fully in line with similar provisions of EU law. Each State Party has undertaken to guarantee the right of access, receipt and dissemination of information to all environmental information subjects regarding the publication of environmental information, national and regional projects planned, national economic development programs and the rest. Such basic obligations of the parties fully reflect the purpose of Directive 2003/4/EC.

According to European environmental law researchers M. Anderson and A. Boyle, over time, some European Parliament and European Commission officials have sought to broaden the scope of information on EU environmental activities and to involve citizens and grassroots movements and groups in direct involvement in environmental protection. Catastrophes (such as Chornobyl) indicate what fatal consequences a lack of information can have ${ }^{26}$. A key element of an effective right of access to information is that stakeholders may not be particularly persistent in obtaining information.

Concerning the implementation of the Ukrainian legislation of the directives within the framework of the Association Agreement, it is worthwhile to note that the Ukrainian legislator should plan work on making the appropriate changes to the normative legal acts of Ukraine in order to ensure the functioning of legal instruments operating in the EU. The system of Ukrainian legislation does not contain a separate normative legal act or provisions regarding public access to environmental justice in the context of another normative legal act whose main purpose is the implementation of all principles of the Aarhus Convention and Directive 2003/4. Access to information shall be foreseen, by leading rank, in accordance with the Law of Ukraine "On Access to Public Information"27.

Also, the legislation of Ukraine does not clearly define the concept of plans and programs in accordance with Directive 2003/35/EC, therefore it is advisable to take this into account in the relevant legislative act or acts, since

\footnotetext{
${ }^{26}$ Boyle A. E., Anderson M. R. Human right approaches to Environmental protection. New York : Oxford University Press, 1996. P. 25-42.

${ }^{27}$ Про доступ до публічної інформації: Закон від 13.01.2011 № 2939-VI. Відомості Верховної Ради України. 2011. № 32. Ст. 314.
} 
the assessment of the environmental impacts of the implementation of plans and programs is one of the voluntary instruments for regulating environmental issues.

\section{CONCLUSIONS}

Basic principles of access to environmental information are enshrined in both Ukrainian and European legislation, ratification of a key document in the research area - the UN Convention on Access to Information, Public Participation in Decision-making and Access to Justice in Environmental Matters implementation of the provisions of the said Convention. However, the list of environmental information in the Law of Ukraine "On Environmental Protection" is narrower than in the Aarhus Convention and Directive 2003/4/EC.

The system of Ukrainian legislation lacks a separate legal act or provision regarding public access to environmental justice as part of another legal act, the main purpose of which is to implement all the principles of the Aarhus Convention. In Ukraine, the information component of environmental policy is extremely weak. It is obvious that the origins of the problem are concentrated in the absence of a system of environmental education and public education that should shape the ecological culture and public consciousness, thereby saturating the information space with this problem. Relevant central government and local government bodies, institutions of higher and secondary education, libraries, NGOs and the media can do much more to inform and raise public awareness of the state of particular natural resources and the environment in general. To do this, the state should formulate its own information, education and education policy in these matters and consolidate it at the legislative level by adopting a single consolidated legal act.

Against this background, it can be noted that the EU's environmental policy is seen as one of the driving forces behind the modernization of public administration in Ukraine. Within the framework of the Association Agreement between Ukraine, on the one hand, and the European Union, the European Atomic Energy Community and their Member States, on the other hand, our country is required to borrow and implement extensive EU legislation in the field of environmental protection and environmental protection. Significant private and public investment in the industry. However, for the sustainable development of environmental legislation, in particular the right to environmental information, a careful harmonization with EU law is needed. This process should be selective and take into account local conditions, national interests and priorities. 


\section{SUMMARY}

The article deals with the analysis of EU environmental legislation. It's essential to further improve and increasing the effectiveness of environmental legislation in Ukraine. An important step in this direction is the right of access to environmental information.

The author analyzes the application of the principle of participation and informing citizens in the legislation of Ukraine in accordance with the provisions of the Association Agreement with the EU. The Association Agreement with the European Union is aimed at securing and realizing the environmental rights of everyone. Every citizen has the right to free access to information about the state of the environmental information and the free acquisition, use, distribution and storage of such information.

The author emphasizes that Ukraine is taking steps to ensure that public authorities have environmental information, as well as create the conditions for further dissemination of such information through computer telecommunications or electronic technologies.

\section{REFERENCES}

1. Бойченюк I. Екологічна інформація та комерційна таємниця. Вісник екологічної адвокатури. 2006. № 30. С. 12-16.

2. Декларация Конференции Организации Объединенных Наций по проблемам окружающей человека среды 1972 г. URL: http://www.un.org/ru/documents/decl_conv/declarations/declarathenv.shtml

3. Добробог Л.М. Інформаційне забезпечення реалізації прав людини на екологічну безпеку. URL: http://www-history.univer.kharkov.ua.

4. Доклад Конференции Организации Объединенных Наций по окружающей среде и развитию Рио-де-Жанейро, 3-14 июня 1992 года A/CONF.151/26/Rev.1 (Vol. I). Нью-Йорк : Организация Объединенных Наций.1993. 519 с.

5. Дубовик О.Л. Экологическое право ЕС: формирование, развитие, достижения и актуальные задачи. Право и политика. 2004. № 12. С. 58-67.

6. Конвенція ООН про доступ до інформації, участь громадськості в процесі прийняття рішень та доступ до правосуддя 3 питань, що стосуються довкілля (Орхуська Конвенція) : Міжнародний документ від 25.06.1998. URL: http://www.unece.org (ECE/CEP/43).

7. Конституція України : Закон від 28.06.1996 № 254к/96-ВР. Відомості Верховної Ради України. 1996. № 30. Ст. 141.

8. Кремер Л., Винтер Г. Экологическое право Европейского Союзу / отв. ред. О.Л. Дубовик. М. : Городец, 2007. 144 с. 
9. Основи законодавства України про охорону здоров'я : Закон від 19.11.1992 № 2801-XII. Відомості Верховної Ради України. 1993. № 4. Ст. 19.

10.Правове регулювання відносин в сфері довкілля в Європейському союзі та в Україні / За заг. ред. В.Г. Дідика. К., 2007. 579 c.

11. Про використання ядерної енергії та радіаційну безпеку : Закон від 08.02.1995 № 39/95-ВР. Відомості Верховної Ради Украӥни. 1995. № 12. Ст. 81.

12. Про доступ до публічної інформації : Закон від 13.01.2011 № 2939-VI. Відомості Верховної Ради Украӥни. 2011. № 32. Ст. 314.

13. Про екологічну експертизу : Закон від 09.02.1995 № 45/95-ВР. Відомості Верховної Ради України. 1995. № 8. Ст. 54.

14. Про забезпечення санітарного та епідемічного благополуччя населення : Закон від 24.02.1994 № 4004-XII. Відомості Верховної Ради України. 1994. № 27. Ст. 218.

15. Про інформацію : Закон України від 02.10.1992 № 2657-XII. Відомості Верховної Ради України. 1992. № 48. Ст. 650.

16. Про охорону навколишнього природного середовища : Закон від 25.06.1991 № 1264-XII. Відомості Верховної Ради Украӥни. 1991. № 41. Ст. 546.

17. Про ратифікацію Конвенції про доступ до інформації, участь громадськості в процесі прийняття рішень та доступ до правосуддя 3 питань, що стосуються довкілля : Закон України від 6 липня 1999 року № 832-XIV. Офічійний вісник Украӥни. 1999. № 28. Ст. 2.

18. Степаненко В.С. Понятие и правовое значение принципов экологической политики ЕС. Политика и общество : Научный гуманитарный журнал. 2006. № 6. С. 83-93.

19. Угода про асоціацію між Україною, 3 однієї сторони, та Європейським Союзом, Свропейським Співтовариством 3 атомної енергії і їхніми державами-членами, 3 іншої сторони. URL : http://www.kmu.gov.ua/control/publish/article?art_id=246581344

20. Boyle A.E., Anderson M.R. Human right approaches to Environmental protection. New York : Oxford University Press, 1996.

21. Council Decision 2005/370 of 17 February 2005 on the conclusion, on behalf of the European Community, of the Convention on access to information, public participation in decision-making and access to justice in environmental matters Convention on access to information, public participation in decision-making and access to justice in environmental matters. Official Journal. 2005. L 124. P. 1-20. 
22. Directive 2003/35/EC of the European Parliament and of the Council of 26 May 2003 providing for public participation in respect of the drawing up of certain plans and programmes relating to the environment and amending with regard to public participation and access to justice Council Directives 85/337/EEC and 96/61/EC - Statement by the Commission. Official Journal. 2003. L 156. P. 17-25.

23. Directive 2003/4/EC of the European Parliament and of the Council of 28 January 2003 on public access to environmental information and repealing Council Directive 90/313/EEC. Official Journal. 2003. L 041. P. 26-32.

24. Reference for a preliminary ruling from the Najvyšší súd Slovenskej republiky (Slovak Republic) lodged on 23 August 2010 - Jozef Križan and Others v Slovenská inšpekcia životného prostredia. Official Journal. 2010. C. 301. P. 11-12.

25. Reference for a preliminary ruling from the Tribunal administratif de Paris (France) lodged on 12 November 2009 - Ville de Lyon v Caisse des dépôts et consignations. Official Journal. 2010. C. 37. P. 29.

26. Request for a preliminary ruling from the Unabhängiger Verwaltungssenat Wien (Austria) lodged on 17 June 2013 - Ferdinand Stefan. Official Journal. 2013. C. 274. P. 2-3.

Information about the author: Kachuriner V. L., $\mathrm{PhD}$, Associate Professor at the Department of State Law Disciplines, International Humanitarian University 33, Fontanska Road str., Odessa, 65009, Ukraine 


\section{CATEGORY OF "PROPERTY" AND SUBJECTS OF PROPERTY RIGHTS PROTECTION OF THE ECHR}

\section{Kizlova O. S.}

\section{Introduction}

The questions of the subjective structure of the procedure for protecting property rights in the ECHR has been controversial for a long time among researchers and lawyers due to the perception that prevailed for quite a long period that commercial organizations cannot be applicants to the European Court of Human Rights (hereinafter referred to as the ECHR). To a certain extent, it was based on the title of the European Convention for the Protection of Human Rights and Fundamental Freedoms (hereinafter referred to as the Convention), which contains an indication of human rights and freedoms; partly - of the wrong interpretation of the provisions of Art. 34 of the Convention, which provides the possibility of applying to the ECHR for individuals, non-governmental organizations or groups of individuals. This misconception about the ability of the ECHR to deal with complaints of commercial organizations also led to the fact that its case practice was not analyzed for the purpose of its use in resolving commercial disputes and therefore did not have the effect that it would, in fact, have on law enforcement (including judicial) practice. This highly pervasive misconception was to some extent "undermined" by the ECHR's ruling on the individual complaint of the Russian joint-stock company "Sovtransavto contra Ukraine" (ECHR judgment of October, 2nd 2003 in the case of "Sovtransavto Holding contrat Ukraine", № 48553 complaint / 99 (CASE of Sovtransavto HOLDING art. UKRAINE). The case is based on the application (№ 48553/99) filled in court against Ukraine by the Russian company 'Sovtransavto-Holding' on May 11th, 1999 in accordance with the Article 34 of the Convention for the Protection of Human Rights and Fundamental Freedoms.

Most other human rights and fundamental freedoms can only be used by private individuals otherwise the articles which regulate these rights and freedoms can be interpreted as not extending to legal persons ${ }^{1}$. At the same time, the European Court of Human Rights also gave more signification to the term "person" according to Convention and allows supporting claims of

\footnotetext{
${ }^{1}$ Гомьен Д. Европейская конвенция о правах человека и Европейская социальная хартия: право и практика / Гомьен Д., Харрис Д., Зваак Л. М., 1998. 598 с.
} 
churches as non-governmental organizations, which are not commercial entities under Art. 1 of Protocol № 1

\section{Substantive composition of the applicants to the ECHR}

Unlike most provisions of the Convention, Art. 1 of Protocol № 1 protects the rights not only of individuals but also of legal entities such as companies. This aspect of this article is important because the economic system of the Member States of the Convention is based on the right of private ownership and the right to freely create such economic units as "legal entities": non-governmental organizations, religious bodies, mass media, etc.

The fundamental principle that defines the subjective side of property law is the principle of equality - all persons have equal legal rights, no one can be discriminated against on the basis of sex, race, color, language, religion, political or other beliefs, national or social origin, belonging to national minorities, property, birth or other circumstances (Article 14 of the Convention) (The judgment of the European Court of Human Rights in the case of Pine Valley Development Ltd and others vs Ireland, November 29,199; The judgment of the European Court of Human Rights in the case of Chassagun and others vs France April 29, 1999). According to this principle, private-law entities have the same rights regarding their property and are subjects to the same property rights regime as individuals.

Also, legal entities have the right to complain to the ECHR, which were eliminated in the bankruptcy process (the judgement in the case "Terem v. Ukraine"), and the sole owners of a certain company.

In order to benefit from the protection of article 1 of the First Protocol, a person must have at least some right under national law that could be considered a property law under the Convention. (Monica Karss-Frisk. The right to property: implementation of article 1 of the First Protocol to the European Convention on human rights) ${ }^{2}$.

As the researchers of the ECHR practice established, the applicant's position should be related to the concept of "victim". That is, unlike some articles of the European Convention, only a real victim, not a potential one, can be protected in the ECHR, in accordance with article 1 of Protocol № 1, in the context of violation of property rights. For a person to be recognized as a" victim", it is necessaryto undergo specific intervention by a public authority. Demonstrative case is "Klass and others V. Germany", according to which the European court pointed out: "To each individual applicant to be

\footnotetext{
${ }^{2}$ Свропейська конвенція 3 прав людини: основні положення, практика застосування, український контекст. /За ред. О. Л. Жуковської. К.: ЗАТ “ВІПОЛ”, 2004. С. 685-722. C. 60 .
} 
actually a victim of violations, which he claims about, he can apply to the ECHR. The European Convention does not grant individuals the right of actio popularis (appeal to the European Court of justice in the interests of the people), does not allow to file a complaint against the law in abstracto just because it violates the Convention. It is not enough for an individual applicant to argue that the very existence of the law violates his right under the Convention. It is necessary that the law was applied with causing appropriate damage tothe applicant"3.

Also, as O. Shupinska belives, the issue of the possibility of persons of public law to be covered by the scope of article 1 of Protocol № 1 is controversial, since the state according to the same rules is primarily as an obligated entity, and all private persons who have the right to demand from the state to respect their property rights are called Owners. If to extend the scope of article 1 of Protocol № 1 to public owners, there is a danger that the ownes and the obligated person with regard to a particular property coincide in the person of one entity. And from the point of view of the theory of subjective rights the owner must necessarily confront the duty-bearers ${ }^{4}$.

The practice of the ECHR has established that state organizations, state enterprises or persons financed from the state budget cannot be applicants to the European court of human rights. This thesis is confirmed by the practice of the European court of justice, which considered disputes involving persons of public law. But, applicants can be state persons (the case "the Former king of Greece and others against Greece").

Regarding the responsibility of the State and the entities whose actions it bears this responsibility for, lawyers note the following:

- actions of the state bodies and their subordinates;

- actions of non-governmental companies, if they are owned by the state or controlled by it; financially and operationally independent of the state, but fulfil socially significant functions (decision in the case "Evaldssonandother V. Sweden").

- actions of municipal enterprises and institutions-schools, kinder gardens, medical establishments;

- actions of local governments.

In order to benefit from the protection of article 1 of the First Protocol, a person must have at least some right under national law that could be considered as a property right under the Convention. This point is demonstrated by the Court hearing of many applications.

3 Що таке право власності та як його захистити в ЄCПЛ// URL: http:// yur-gazeta.com/publications/events/shcho-take-pravo-vlasnosti-ta-yak-yogo-zahistiti-v-espl.html

${ }_{4}^{4}$ Шупінська О. Міжнародні правові механізми захисту права власності: практика Європейського суду з прав людини / Олена Шупінська. // Юстініан. 2008. № 11. 


\section{The concept of property rights in the attitude of the ECHR}

The concept of property rights in the attitude of the ECHR is characterized by the "value" concept of property rights. The value concept of property rights is based on the provisions of the basic European standards and it is characterized by: equality of subjects of private property, the extension of property rights to objects that are characterized by signs of economic value regardless of their tangible or intangible nature, besides the list of such objects is not exhaustive and constantly expands with the development of economic relations, the imposition of obligations to ensure and protect property rights to the state, broad powers of the owner, etc. In addition, there may be differentiated regimes of absolute property law for different objects, as well as the existence of absolute property law in respect of rights arising from the enforceable relationships. The content of the property law is characterized by the ability of the subject at its discretion to perform any actions that are not prohibited against the object of the property law.

The provisions of EU law regarding property law, the provisions of property law in EU States and the provisions of legislation with regard to the property law in non- EU member States of the Council of Europe are not unified, since the $\mathrm{EU}$ is currently in the process of harmonizing property law and the process of creating an acquis communautaire in the sphere of property law (in particular, ideas are being put forward for the preparation of the draft European Civil code, but they relate to the draft acts of EU legislation as early as 2010 and are at the initial stage of development and discussion.

Taking into account the practice of the European court of human rights, scientists argue ${ }^{5}$, that the category of property law in the Convention for the protection of human rights and fundamental freedoms has an Autonomous meaning and may not coincide with what is accepted in national legal systems.

This opinion is held by Russian legal scholars V. V. Starzhenetsky and I. V. Mingazova and explained by the fact that the application and interpretation of international treaties corresponds to international legal rules, and legal constructions adopted in national legal systems cannot have a determining value for international legal regulation ${ }^{6}$. That means there is a special concept of the of property law which is independent from the domestic interpretation at the international level. The Convention is an international Treaty, therefore, the process of interpretation and application of its provisions is subject to international legal rules.

${ }^{5}$ Шупінська О. Міжнародні правові механізми захисту права власності: практика Європейського суду з прав людини / Олена Шупінська. // Юстініан. 2008. № 11.

${ }^{6}$ Старженецкий В. В. Соотношение международного (европейского) и российского правового регулирования института собственности. М., 2003. С. 88; Мингазова И. В. Право собственности в международном праве/ И. В. Мингазова. М.: Волтерс Клувер, 2007. C. 5. 
The Institute of the Protection of Property Rights received a special growthin the decisions of the European Court of Human Rights, which can be defined as a departure from the substantive concept of property law that is common for Ukrainian property law. To qualify a particular object of legal relationship as "property", the first and main sign is "economic value". As to interpretation of European judges, the Institute for the Protection of Property Rights must extend to all current assets thatare characterized by economic value, regardless of their tangibility or intangibility ${ }^{7}$.

The other feature is the sign of reality, since property must exist in the real world. The experience of the European Court of Human Rights shows that Art. 1 of Protocol № 1 is applied only to real property, not to the right to acquire property. The case of Malous v. Czech Republic is significant, where the European Court of Human Rights disagreed with the applicant that he owned the property expropriated by the applicant's father under the 1948 national law. The European Court of Human Rights stated that, in the course of the domestic proceedings, neither the father nor the applicant, as his heir, owned the expropriated property. Therefore, in this case it is impossible to talk about "existing" or available property. (the judgment in the case of Malous v. Czech Republic of December 13th, 2000).

There is a dispute about the definition of the object of protection which is defined in Article 1 of Protocol № 1 in the scientific community. For instance, O. Shupinska considers, referring to S. Shevchuk, that the object of protection of the Convention is property rights, according to the content of Art. 1 everyone is guaranteed with the right to respect for his property and certain guarantees of the rights of individuals are provided in case of interference by the state in their rights. The Court directly stated that Article 1 guarantees "ownership": this is a direct consequence of the use of the words "ownership" and "use of property" (in French, "biens", "propriété, "usage des biens"); the preparatory materials also confirm this unequivocally: the developers have repeatedly referred to "property law" or "right to property" to delineate the object of projects that preceded the adoption of Article 1 of Protocol № 1. Indeed, the right to dispose of property is a traditional and fundamental aspect of property law ${ }^{8}$. Some scientists also point out that property law can be positively enshrined in the Convention as a fundamental human right ${ }^{9}$.

\footnotetext{
${ }^{7}$ Старженецкий В. В. Россия и Совет Европы: право собственности. М., 2004. 208 с. C. 50.

${ }^{8}$ Шевчук С. Судовий захист прав людини: Практика Європейського Суду 3 прав людини у контексті західної правової традиції. Вид. 2-е випр., доп. К.: Реферат, 2007. C. $695-701$.

${ }^{9}$ Нешатаева Т. Н. Международное частное право и международный гражданский процесс. М., 2004. 624 с. С. 165-166; Старженецкий В. В. Россия и Совет Европы: право собственности. М., 2004. 208 с. С. 46.
} 
Nevertheless, according to Professor N.S. Kuznetsova, there is nothing about property in the Convention, instead of it the term "possessions" is used in Art. 1 of the First Protocol which is intepreted as property. Michele de Salvia, a professor of law and legal counsel at the EUHR points out that any object that has property values can be a protected ${ }^{10}$.

N.S. Kuznetsova states that without any doubt virtually the only prescription relating to property - the Convention combines all the rights of a natural or legal person with property value. In some places they are called "economic assets". Such a broad approach to the definition of objects is covered by state guarantees within the meaning of Art. 1 of the First Protocol as well as is confirmed by the ECHR practice ${ }^{11}$.

The Convention integrates all the rights of a natural or legal person, which include property value in Art. 1 of the First Protocol, in virtually a single prescription relating to property.

In addition, it should be noted that the European Court's interpretation of property law is not absolute and should be restricted in the name of the general interest of society. Exactly this idea - limiting the absolute right of everyone for the benefit of all - is the cornerstone of conteprorary judicial protection of property. However, restrictions on property rights cannot be arbitrary: in States Members of the Convention property rights can be restricted to the common good in only two forms: control over its fair use (a positive duty of the State) and deprivation of the owner's property with reimbursement (right, but not obligation of the state).

Considering Art. 1 of the First Protocol to the Convention and the mechanism for its application, it is necessary to remember the three provisions which form the content of this article:

(I) The principle of peaceful possession of property;

(II) Deprivation of property;

(III) Control of usage ${ }^{12}$.

Otherwise, Article 1 of Protocol № 1 has three main provisions:

1) Respect of the property rights ("Every natural and legal person has the right to peacefully own his property");

2) impossibility of deprivation of property ("No one may be deprived of his property except in the interests of society and under the conditions provided by law and the general principles of international law");

10 Право власності: європейський досвід та українські реалії: Збірник доповідей і матеріалів Міжнародної конференції (м. Київ, 22-23 жовтня 2015 року). К.: ВАІTЕ, 2015. 324 c. C. $24-34$

${ }^{11}$ Дивись там же

12 Дивись там же 
3) conditions of restriction of property law in the form of control of the state over its usage ("The preceding provisions shall not detract from the right of the state to enforce such laws as it seems necessary to control the usage of property in accordance with the common interest or to secure the payment of taxes or other fees or penalties ").

The principle of the inviolability of property rights in EU law and in EU countries provides an opportunity to interpret more broadly the notion of "the person's property and his estate" beyond the framework of the established concepts of "property", "thing". Nowadays if to proceed from the "economic relations" of property, paying particular attention to the fact that the concept "property" ("property" / "possessions" / "biens", etc.) is considered in EU law more broadly than the classic "triad" of property rights. Firstly, property relations in the EU are governed by aspect of the EU's four fundamental freedoms regarding free economic choice of "goods, persons, services and investment". Secondly, the concept of "property", which is self-contained in the context of the Convention, refers to a fairly broad category of economic-industrial relations (this is confirmed by the experience of the European Court of Human rights).

The content of property law in the general sense is the right of ownership, usage and disposal. The provisions of the Convention do not define the use of the property, but the precedents make it possible to conclude that the owner may be obliged to take certain actions regarding his property, and the rights to use that property may be restricted by the state. The right to dispose of property in accordance with Art.1 of the First Protocol is a traditional and fundamental aspect of property law. This right provides for the possibility of the owner entering into a legal relationship with another person, regardless of the form which these relationships occur in ${ }^{13}$.

The ECHR interprets the concept of "property" much wider and in the context of article 1 of the First Protocol," property "means not only "existing property", but also a number of economic interests (assets) in contrast to the common understanding of the institution of property law which is typical for Ukraine, as well as in general for the States of the continental system of law. In addition to movable and immovable property, there are shares (and not only in terms of their value, but also in terms of the rights to control the enterprise, which they provide to the owner), patents, licenses, professional clientele ("reputation"), financial compensation awarded by a court decision, the right to a retirement, etc. those are in particular under the protection of article 1 of the First Protocol.

${ }^{13}$ Мармазов В. Є. Захист прав та майнових інтересів у Європейському суді 3 прав людини : навчально-практичний посібник/ В. Є. Мармазов, П. В. Пушкар; ред. М. В. Оніщук. К.: Видавничий Дім “Юридична книга”, 2001. 156 с. 
It should also be noted that the position of the ECHR does not differ from the modern concept of property law. The modern stage of development of property law is characterized by the expansion of its subject area. Experience has shown that the most acceptable legal regime for new objects is the regime of ownership, and therefore it will be useful once again to refer to the legal content of the concept of "thing". Part 1art. 177 of the civil code of Ukraine refers to things money and securities. That underlines the fact that the times when "things" were literally understood by a person as surrounding objects have passed. Another evidence of changing views from the classical paradigm can be considered the appearance in the code of such a complex object as the enterprise. Indeed, an enterprise is not a thing but a property complex including among other things exclusive rights, claims and debts (article 191 of the civil code of Ukraine), and yet it is the subject of not only transactions, but also property rights. On the other hand, these examples are rather an exception (so, to include the enterprise in the property turnover a special article was needed) and the basic prejudice remains almost unchanged. Things as an object of property rights can be divisible and indivisible, movable and immovable, complex and simple, etc., but they remain primarily things for which the defining feature is tangibility (article 179 of the civil code of Ukraine).

And here again it is useful to turn back to history. Roman law was aware of the division of things into "tangible "and "intangible", which occurs in the institutions of Gaius (2.12-14). As an example of what is to be understood by a disembodied thing, Gai imposed the right of inheritance, the right of usus fructus, and the law of obligation. "Comparing this sources with the examples which were given by Gai, it is necessary to admit that dividing things into tangible and intangible, Gai means by the last not things in sense of objects of the external world, but the rights".

Since when trying to apply the regime of property to rights, as well as when trying to include rights in the list of objects of civil rights (art. 177 of the civil code of Ukraine), there is a paradox of "right to law", "intangible things «of Roman law, as it seems to us, can hardly serve as an effective tool for regulating intellectual property relations. Another point of view of D.V. Murzin is:"... intangible property appeared in Roman private law because of its unsurpassed logic reaching to primitiveness in its private manifestations; intangible property was rejected by post-Roman civil law through the practicality of Western civilization and its excessive fascination with the philosophy of materialism"14.

\footnotetext{
${ }^{14}$ Мурзин Д. В. Ценные бумаги - бестелесные вещи. Правовые проблемы современной теории ценных бумаг. М., 1998. С. 70.
} 
Article 1 of Protocol № 1 protects the traditional concept of ownership, which includes movable and immovable property (rights in rem), relationships between individuals (rights in personam), public relations, and intellectual property.

The court, in particular, recognized that the guarantees of Art. 1 of Protocol № 1 shall also apply to such specific facilities as:

- amounts awarded by a final and binding court or arbitration decision; (Stran Greek refineries and StratisAndreadis v. Greece, Application N 13427/87. European Court of Human Rights, Judgment of 9 December 1994.);

- right to refund export VAT; (ntersplav v. Ukraine, Application N 803/02. European Court of Human Rights, Judgment of 5 December 2006);

- the right to a refund of excessively paid tax; (Buffalo SRL v. Italy, Application N 38746/97. European Court of Human Rights, Judgment of 3 July 2003).

- licenses to carry out business activities or provide certain services; (Tre TraktorerAktiebolag v. Sweden, Application N 10873/84. European Court of Human Rights, Judgment of 7 July 1989; Capital Bank AD v. Bulgaria, Application N 49429/99. European Court of Human Rights, Judgment of 24 November 2005.);

- clientele and business relations of the company; (Van Marle and others v. Netherlands, Application N 8543/79. European Court of Human Rights, Judgment of 26 June 1986.);

- domain name; (Paeffgen GmbH $(I-I V)$ v. Germany, Applications N 25379/04, 21688/05, 21722/05, 21770/05. European Court of Human Rights, Decision of 18 September 2007.);

- right to shares; (Sovtransavto Holding v. Ukraine, Applications N48553/99. European Court of Human Rights, Judgment of 25 July 2002);

- the right to engage in fishing (Posti and Rahko v. Finland, Applications N 27824/95. European Court of Human Rights, Judgment of 24 September 2002);

- a share in a pension fund (Müller v. Austria, decree admissibility of Application No 6849/72, filed by Christian Muller v. Austria, December 16, 1974);

- property rights, for example, the right to rental charge (rent) for the use of the land acquired on the basis of a will (decree admissibility No 10741/84 S. v. the United Kingdom of 13 December 1984);

- Private property interests recognized under national law (Beyeler v. Italy, Case [GC] of 5 January 2000, application no. 33202/96); 
- movable property, such as a painting (in particular, "Portrait of a Young Peasant" by Van Gogh, was the subject of consideration in Beyeler v. Italy [GC] of 5 January 2000, application No. 33202/96), or the belongings of the person in his residence (Novoseletskiy v. Ukraine, application no. 47148/99, decision of 22 February 2005) etc ${ }^{15}$.

Therefore, if a person has a certain right that is of economic value and is civil in nature, then such a right undoubtedly constitutes "property" in the sense conferred on it by the ECHR. Property covers a) rights in things (rights in rem) and b) rights in claims (rights in personam). And the property also includes those rights to things that come from contracts ${ }^{16}$.

For instance, the Court took into account, in particular, the legal position which led to financial rights and interests and whether they had economic value in cases involving intangible assets (Paeffgen $\mathrm{GmbH}$ against Germany 18.09.2007, 25379/04 21688/05 21722/05 21770/05 (déc.)). In General, as the researchers establish, prima facie taxation directly concerns property issues, since (in a simplified form) according to the results of taxation, the total value of the relevant property of the person is reduced by the amount of the relevant. But of course the position of the mentioned article of the first Protocol was not adopted to get rid the States of the right to receive taxes, as noted in paragraph two of the article.

Thus, the concept of "property" means not only things (in their classical sense), but any other property that has a certain economic value (economic assets). Moreover, this concept also covers objects that, in Russian law, are quite problematic to attribute to property, but which have undisputed economic value.

According to the 1st article of Protocol № 1, the exception to the concept of "property" can be only the objects that, by virtue of the direct prohibition established by national or international law, are withdrawn from economic circulation or those objects that cannot be owned by private persons, although in fact they will have economic value (for example, some weapons, radioactive materials, drugs).This limitation of private property rights is justified on grounds of public interest, so the state has some discretion in determining what may or may not be the subject of private property rights.

15 Фулей Т. І. Застосування практики Європейського суду 3 прав людини при здійсненні правосуддя: Науково-методичний посібник для суддів. 2-ге вид. випр., допов. K., 2015.208 c. C. $128-130$

${ }^{16}$ Карнаух Б. П. Поняття майна в контексті статті 1 Протоколу № 1 до європейської конвенції про захист прав людини $\mathrm{i}$ основоположних свобод// URL: https://docviewer.yandex.ua/?url=http $\% 3 \mathrm{~A} \% 2 \mathrm{~F} \% 2 \mathrm{Fplaw}$. nlu.edu.ua\%2Farticle $\% 2 \mathrm{Fdownload} \%$ 2F59090\%2F62273\&name $=62273 \&$ lang $=u k \& c=58 \mathrm{dbf} 8163814$ 
In addition, the property does not necessarily have to belong to a person on the right of ownership. This may be another legal right (for example, the property may belong to a person on the basis of a lease agreement, as indicated by the Court in the case "Iatridis v. Greece").

The question of property arises only when a person can be eligible for the relevant property, that is, have a right to it. The right itself to property can be considered within the meaning of article 1 of Protocol № 1, if such a right is specific, properly defined in the applications submitted to the European court of human rights.

On the other hand, the provisions of article 1 of Protocol No. 1 do not guarantee any possibility to become the owner of a particular property.

Thus, the right to index citizens 'savings is not guaranteed as such by the 1st article of Protocol № 1 of the Convention. In decisions "Rudzynska v. Poland", "Trajkovski v. the former Yugoslav Republic of Macedonia", "Hajduk and others v. Ukraine", the Court noted that the specified article does not establish for States of a common debt to carry out systematic indexing of savings to correct the harmful effects of inflation and to preserve the purchasing power of the invested funds, and the applicants are not victims of violation by the state under Protocol № 1 of the Convention, since they did not claim for their real property (that is, the funds that were actually put by the applicants in the Bank, regardless of their present real value), a claimed for benefits (Compensation payments) which they were not entitled at the time for, as this was not provided for by the compensation legislation. Consequently, payments from compensation accounts do not fall within the scope of article 1 of Protocol № 1 of the Convention.

The European Court of Human Rights has repeatedly stated in its decisions that there is no ownership of the property until such a person can assert his ownership. "Statement of rights" may mean "possession of property" referred to in Article 1 of Protocol № 1 to the Convention, if there are sufficient grounds for enforcing this right through a court of law.

Thus, the concept of property rights applied by the Court is very broad and is not limited to material things, but also covers the whole range of intangible objects from intellectual property to obligatory claims.

The concept of "property" within the meaning of Article 1 of the first Protocol to the Convention is self-contained. This means, first of all, that the national legislation of the States Parties of the Convention cannot be considered final in ascertaining of its content. In the case of "Yatridis v. Greece" the European Court stated that the concept of property in Article 1 of Protocol № 1 has self-contained content, which is not limited by the 
ownership of material things. Some other property rights and benefits may also be property rights ${ }^{17}$.

According to the lawyers, self-containment of the concept of property is a necessary measure of the part of the European Court of Justice, whereas, on the one hand, it is intended to promote and secure the right to peaceful possession of a person of his property, on the other, it is connected with the application of a broader concept, that the Council of Europe is composed of a large number of States which have their own national legislation. And the purpose of the European Convention is to set minimum standards that would comply with the legislation of any democratic country that is a member of the Council of Europe.

According to O. Belyanevich, self-containment of concepts does not allow to states to formulate in their national legislation such definitions that would violate the balance of private and public interests. The autonomy of concepts must not be seen as a requirement of unification, but only as a requirement to apply unified rules and principles of the interpretation; in other words, it promotes the harmonization of enforcement standards ${ }^{18}$.

ECHR accepts flexibility in interpretation of terms by law enforcement authorities of State Member - the main things: to be reasonable and to meet the objectives of the Convention ${ }^{19}$.

At the same time, the Court may find it appropriate to apply national law. Thus, the concept of "property", according to the practice of the ECHR, provides for awareness - primarily at the national level - with the position of the court on certain issues. This problem is particularly relevant when the Court's approach is more broaden than that of a national legislator.

For example, the recognition of property as "legitimate expectations" does not fit into the traditional outline of civil rights objects under the current Civil Code of Ukraine, as well as the recognition of economic interests under a license to implement a certain type of activity. Enabling acts at the same time can be recognized as "assets" and covered by the concept of "property". Such situations will require to resolve cases taking into account not only national law, but also the ECHR Convention and practice, taking into account the requirements of the Law of Ukraine "On the Enforcement of Judgments and the Practice of the European Court of Human Rights" of February 23, 2006 No. 3477-IV.

17 Фулей T.I. Застосування практики Європейського суду 3 прав людини при здійсненні правосуддя: Науково-методичний посібник для суддів. 2-ге вид. випр., допов. K., 2015. 208 c. C. 130

18 Право власності: європейський досвід та українські реалії: Збірник доповідей і матеріалів Міжнародної конференції (м. Київ, 22-23 жовтня 2015 року). К.: ВАІTЕ, 2015. 324 c. C. $143-156$.

${ }^{19}$ Дивись там же 
According to O. Belyanevich, "smart expectations" of a person can only be considered legitimate (or legal) expectations. In most cases, the concept of "legitimate expectations" is considered as an element of the rule of law and as an element of "juridical certainty", although it is being disputed. At the same time, "legitimate expectations" are also considered as an object of legal protection (security).

The understanding of "legitimate expectations" as an element of legal certainty was embodied in the case-law of the European Court of Justice, which emphasized in Salumi's case that the effect (consequences) of Community law should be clear and foreseeable to those whom it applies to ${ }^{20}$.

As the scientist notes when applying the self-containment concept of "legitimate expectations" it is necessary to consider the following:

1) in the practice of the ECHR, material things and obligations are analysed in terms of the autonomous concept of "property";

2) the national legislation of Ukraine allows to resolve disputes arising in obligations and concerning the protection of the creditor's right by means of the existing legal structures, therefore the application of the concept of "legitimate expectations" will unjustifiably burden and complicate the practice;

3 ) in terms of provision of legal order in the country, the principle enshrined in Part 2 of Art. 19 of the Constitution of Ukraine is prioritized and cannot be opposed by the autonomous concept of "legitimate expectations";

4) in the conditions of unstable legal order, a transfer of autonomous concepts of the ECHR to the domestic platform should be very careful, since the actions of the party may hide lack of integrity ${ }^{21}$.

The practice of the ECHR and international arbitration recognize that the fundamental of reasonable expectation cannot deny the right of States to amend their legislation. According to Part 2 of Art. 328 of the Civil Code of Ukraine the right of ownership is considered legitimate, unless otherwise directly follows from the law or the illegality of the acquisition of ownership is not established by the court. If the court establishes the illegality of the acquisition of ownership, there is no reason to apply the concept of "legitimate expectations" or give it an advantage over the rules of Art. 19 of the Constitution of Ukraine and the Civil Code of Ukraine on the acquisition of property rights.

\footnotetext{
${ }^{20}$ Право власності: європейський досвід та українські реалії: Збірник доповідей і матеріалів Міжнародної конференції (м. Київ, 22-23 жовтня 2015 року). К.: ВАІTЕ, 2015. 324 c. C. $143-156$.

${ }^{21}$ Право власності: європейський досвід та українські реалії: Збірник доповідей і матеріалів Міжнародної конференції (м. Київ, 22-23 жовтня 2015 року). К.: ВАІTЕ, 2015. 324 c. C. $143-156$.
} 
The theory of legal expectations is quite complex and concerns various spheres of private and public laws, - I. Al-Fateeva states. In civil law, this theory or doctrine is promoted quite problematic, although in the 90s there was a reason for it, when the court practice maintained the existence of the rights of the person to the apartment, which should have come by the implementation of the person's right to privatization, but this person died after submitting the relevant documents for privatization, without becoming the owner of the apartment ${ }^{22}$.

In contrast to the "legitimate expectations" of property are not recognized:

(a) «the expectations that property law, which has long since ceased will be renewed";

b) claims, the effect of which ab initio is due to certain circumstances - if such circumstances do not occur.

An interesting example in this issue is the case of Polachek and Polachkova V. the Czech Republic ${ }^{23}$.

It is important to note that a claim cannot be considered a "legitimate expectation" if it is conditional. Thus, article 1 of Protocol № 1 does not guarantee the right to acquire property by inheritance. This approach was applied by the ECHR in the case "marks V. Belgium", where the Court pointed out that article 1 of Protocol №. 1 protects the already existing property of a person and does not guarantee the right to acquire property either by will or in any other way.

In order to prove that the interference with the property right took place, it is necessary to show that the protection guarantees provided for in article 1 of Protocol No. 1 were violated.

As V. Mikhailenko noted ${ }^{24}$, despite the fact that article 1 establishes the possibility of a person to peacefully own their property, it also has a number of restrictions and features, in particular:

- provides for the protection of their property;

- States the right of any person to freely dispose of his property;

- does not guarantee the acquisition of property;

- does not provide for the creation of a new ownership of the property;

\footnotetext{
${ }^{22}$ Право власності: європейський досвід та українські реалії: Збірник доповідей і матеріалів Міжнародної конференції (м. Київ, 22-23 жовтня 2015 року). К.: ВАІTЕ, 2015. 324 c. C. $79-87$.

${ }^{23}$ Polacek and Polackova v. Czech Republic (dec.) [GC], no. 38645/97, § 62, 66, ECHR [Електронний ресурс] // HUDOC. URL: http://hudoc.echr.coe.int/sites/eng/pages/ search.aspx $? \mathrm{i}=001-22564$.

24 Що таке право власності та як його захистити в ЄCПЛ// URL: http:// yur-gazeta.com/publications/events/shcho-take-pravo-vlasnosti-ta-yak-yogo-zahistiti-v-espl.html
} 
- does not guarantee the preservation of the equivalent value and does not oblige the state to maintain the purchasing power of sums of money placed in financial institutions;

- does not grant foreigners who own property in another country the right of permanent residence in the country for the purpose of using their property.

V. Mikhaylenko points out that «when we appeal to the European court, it should be understood that not any violation of property rights will be recognized as a violation, in the case there are always 2 subjects: the applicant and the defendant. The defendant in the ECHR is always the state. And the property right, accordingly, will be protected by the state only when interference with this right at the national level was caused by the state"25.

Thus, in each specific issue, in each case in which a violation of property rights is involved, the Court checks the actions or omissions of the state, taking into account the balance between the needs of the General public need and the preservation of the fundamental rights of the person. First of all, relying on the fact that the concerned person should not bear a disproportionate and exorbitant burden (the decision in the case "Sporrong and Lonroth V. Sweden").

To assess the conduct of the state in the context of compliance with the requirements of article 1 of the First Protocol, the Court must make a full study of the various interests in the case, taking into account that the purpose of the Convention is to protect rights that are "obvious and weighty". Among other things, the existence of a controversial situation is established. At the same time, when the issue of public benefit does arise in the case, the ECHR requires the state authorities to "respond properly, correctly and with great responsibility" (the decision in the case of "Vasilescu V. Romania" and "beiler V. Spain").

\section{SUMMARY}

So, since the ideology of article 1 of the First Protocol is actually reflected in the Constitution and the Civil code of Ukraine, the national courts should take into account legal positions of the ECHR in disputes on protection of property rights, to refer to the conclusions of the ECHR as a direct source of law, and to adopt in its decision the idea of justice and humanity.

25 Що таке право власності та як його захистити в ЄCПЛ// URL: http://yurgazeta.com/publications/events/shcho-take-pravo-vlasnosti-ta-yak-yogo-zahistiti-v-espl.html 


\section{REFERENCES}

1. Гомьен Д. Европейская конвенция о правах человека и Европейская социальная хартия: право и практика / Гомьен Д., Харрис Д., Зваак Л. - М., 1998. - 598 с.

2. Європейська конвенція 3 прав людини: основні положення, практика застосування, український контекст. / За ред. О. Л. Жуковської. - К.: ЗАТ “ВІПОЛ”, 2004. - С. 685-722. - С. 60.

3. Що таке право власності та як його захистити в ССПЛ // Режим доступу : http://yur-gazeta.com/publications/events/shcho-take-pravovlasnosti-ta-yak-yogo-zahistiti-v-espl.html

4. Шупінська О. Міжнародні правові механізми захисту права власності: практика Європейського суду з прав людини / Олена Шупінська. // Юстініан. - 2008. - № 11.

5. Старженецкий В. В. Соотношение международного (европейского) и российского правового регулирования института собственности. - М., 2003. - С. 88.

6. Мингазова И. В. Право собственности в международном праве / И. В. Мингазова. - М.: Волтерс Клувер, 2007. - С. 5.

7. Старженецкий B. В. Россия и Совет Европы: право собственности. - М., 2004. - 208 с. - С. 50.

8. Шевчук С. Судовий захист прав людини: Практика Європейського Суду з прав людини у контексті західної правової традиції. - Вид. 2-е випр., доп. - К.: Реферат, 2007. - С. 695-701.

9. Нешатаева Т. Н. Международное частное право и международный гражданский процесс. - М., 2004. - 624 с. C. $165-166$.

10. Мармазов B. Є. Захист прав та майнових інтересів у Європейському суді з прав людини : навчально-практичний посібник / В. Є. Мармазов, П. В. Пушкар; ред. М. В. Оніщук. - К.: Видавничий Дім "Юридична книга", 2001. - 156 с.

11. Римское частное право: Учебник / Под ред. проф. И. Б. Новицкого и проф. И. С. Перетерского. - М.: Юриспруденция, 2000. -448 c. С. 148.

12. Мурзин Д. В. Ценные бумаги - бестелесные вещи. Правовые проблемы современной теории ценных бумаг. - М., 1998. - С. 70.

13. Фулей T.I. Застосування практики Європейського суду з прав людини при здійсненні правосуддя: Науково-методичний посібник для суддів. - 2-ге вид. випр., допов. - К., 2015. - 208 с. С. 128-130

14. Карнаух Б.П. Поняття майна в контексті статті 1 Протоколу № 1 до європейської конвенції про захист прав людини і основоположних свобод // Режим доступу : https://docviewer.yandex.ua/?url=http\%3 
A\%2F\%2Fplaw.nlu.edu.ua\%2Farticle\%2Fdownload\%2F59090\%2F62273\& name $=62273 \&$ lang $=$ uk $\& c=58 \mathrm{dbf} 8163814$

15. PolacekandPolackovav. Czech Republic (dec.) [GC], no. 38645/97, $\S 62$, 66, ECHR [Електроннийресурс] // HUDOC. - Режим доступу: http://hudoc.echr.coe.int/sites/eng/pages/search.aspx?i=001-22564.

16. Що таке право власності та як його захистити в ЄСПЛ // Режим доступу : http://yur-gazeta.com/publications/events/shcho-take-pravovlasnosti-ta-yak-yogo-zahistiti-v-espl.html

\section{Information about the author:}

Kizlova O. S.,

Doctor of Laws, Professor, Head of the Department of Civil and Business Law and Process, International Humanitarian University 33, Fontanska Road str., Odessa, 65009, Ukraine 


\section{COOPERATION OF STATES IN THE FIGHT AGAINST CRIME}

\section{Klyuev O. M.}

\section{INTRODUCTION}

The magnitude and globality of the consequences of international crimes necessitate the establishment of relations between States and international organizations to combat such negative manifestations. Over the entire history of cooperation between subjects of international law in combating crime, a fairly large body of international legal norms, principles and mechanisms for preventing, combating, suppressing and investigating international crimes has accumulated.

The process of establishing cooperation in combating international crimes actually begins with the period of origin of relations between the first developed States, when the first bilateral treaties on extradition of criminals were concluded. In the future, the development of international relations in the fight against crime actually takes place in the context of the development of international law. Each historical period posed new challenges to the international community, required the concentration of joint efforts in solving economic, political, social problems, including the problems of combating international crimes ${ }^{1}$.

\section{The main directions and forms of international cooperation of States in the fight against crime.}

The fight against crime is one of the priority areas of international cooperation. Its growth and internationalization turned this struggle into one of the main social problems and made it necessary for States to cooperate in solving it.

The main modern directions of cooperation of States in the fight against crime are:

- joint determination of the range of generally dangerous acts requiring joint efforts to suppress them;

- mutual exchange of information on committed crimes and criminals;

- assistance in tracing criminals located on the territory of the state and their extradition to interested subjects of international law;

${ }^{1}$ Shostko Elena Combating organized crime in European countries: monograph. National law Academy of Ukraine. Yaroslav The Wise. Kharkiv: Pravo, 2009. Forty, 
- joint study of crime and methods of combating it; implementation of separate instructions on criminal procedural issues;

- conclusion of international treaties on combating certain types of international criminal acts;

- participation of States in international organizations specializing in the fight against crime.

The purpose of such cooperation is:

a) harmonization of the qualification of international crimes;

b) mutual legal assistance in criminal cases, including extradition of the offender;

c) coordination of efforts and measures to prevent and suppress crimes;

d) combating certain categories of the most dangerous crimes;

e) joint solution of certain tactical tasks of investigation (search for criminals, hiding, stolen things, etc.);

f) combating transnational crimes in certain areas of activity (transport, foreign trade);

g) ensuring the inevitability of punishment.

The objectives of international cooperation in the fight against crime are:

- interaction at the interstate level;

- formation of international coordinating bodies;

- interaction at the level of individual agencies involved in the fight against international and transnational crime;

- interaction between law enforcement agencies of neighboring regions of two or more countries.

Thus, international cooperation in the fight against crime is a comprehensive coordination of actions of sovereign States, international organizations, which are aimed at developing and coordinating measures for the prevention, disclosure of certain types of crimes and the identification, detention and transfer of offenders to justice, as well as the definition of goals and objectives to minimize transnational and intra-national illegal acts.

Based on the above, it can be stated that the forms of international cooperation in the fight against crime are:

- coordination of actions to combat crime (exchange of information);

- signing of treaties on combating international crimes and crimes of an international character;

- legal assistance in criminal cases;

- carrying out operational search activities;

- conducting investigative actions;

- crime prevention; 
- joint measures to suppress criminal actions and bring perpetrators to

International cooperation of States in this important area is based on a system of certain criteria, standards, that is, international principles that determine the essence of the organization and activities of States and international organizations in the fight against international criminal acts.

In accordance with article 2, paragraph 4, of the UN Charter, "all UN members shall refrain in their international relations from the threat or use of force...". The duty of non-use of force applies to all States and is the basis for cooperation between States in various fields, including the fight against crime. The normative content of this principle can be stated in the following main provisions:

- Cooperation between States in the fight against crime should be based on a voluntary basis, without any coercion by force or threat of force;

- Problems arising from cooperation in the field of criminal justice cannot be used for the unjustified direct or indirect use of force or threat of force.

The UN Charter provides for only two exceptional cases in which armed force may be used: in self-defense (article 51) and by decision of the UN Security Council in the event of a threat to the peace, breach of the peace or act of aggression (articles 39 and 42).

Feature of the principle of peaceful settlement of international disputes is a wide range of means of peaceful settlement of disputes, as the UN Charter gives the parties freedom of choice such peaceful means as negotiation, mediation, conciliation, arbitration, trial, appeal to regional bodies and the like. When resolving a dispute in the field of criminal justice, States have the right to independently choose the method of its peaceful solution, contained, as a rule, in the texts of the Treaty ${ }^{3}$.

The arbitration method of dispute resolution is provided in particular: the Convention on laundering, search, seizure and confiscation of proceeds from crime 1980, the Convention for the suppression of unlawful acts against the safety of civil aviation 1871, the UN Convention for the suppression of illicit traffic in narcotic drugs and psychotropic substances (19 December 1988).

In accordance with the principle of non-interference in internal Affairs, no state or group of States has the right to interfere in the internal Affairs of

${ }^{2}$ Kutsevich Maxim criminal liability for ecocide: international and national aspects: monograph / M. Kutsevich; Kyiv national University. Of Taras Shevchenko. Kyiv: Yuridichna Dumka, 2009. 332 p.

${ }^{3}$ Al-Batran Khaled Regulatory framework for countering international terrorism within the framework of the Organization of Islamic Cooperation: abstract. dis. ... Yuri. Sciences: 12.00.11. NATs. UN-t odes. Yuri. Acad. Odessa, 2012.17 p. 
any state (article 2, paragraph 7 , of the UN Charter). We emphasize that the fight against crime is a matter of internal competence of the state. Based on this and guided by the universally recognized principle of non-interference, the following main provisions of the application of this principle in the fight against crime can be distinguished:

- States independently determine specific areas of cooperation, as well as partners of cooperation in the fight against crime. This provision is embodied in the fact that the state has the right to independently conclude treaties on legal assistance, as well as agreements on combating certain types of crimes, to join international organizations dealing with crime;

- States are free to determine the scope of cooperation. This provision is reflected in practice by making reservations to the relevant treaties, as well as by determining the forms of participation in international conferences, seminars devoted to the fight against crime;

- When applying the rules of international law, no one can interfere in the internal Affairs of other States. It is this warning that determines the Advisory nature of the UN resolutions and it's International Congress on combating crime and Interpol decisions;

- When concluding treaties against crime, all procedural issues are resolved only in accordance with the domestic legislation of the state. Criminal prosecution is carried out based on national substantive and procedural law and cases are considered by the competent national courts ${ }^{4}$.

Among the special principles in the field of international legal fight against crime can be identified non-extradition of citizens and political immigrants. Cooperation of States in the fight against crime is conducted only with regard to common crimes. Those charged with political crimes or prosecuted for political reasons are not subject to international treaties.

Inevitability of punishment. The legal content of this principle is that every person who has committed a crime must be punished.

Humanity. Punishment should correspond to the purpose of resocialization of the criminal. The goal is not only punishment, but also reeducation and correction.

Protection of the rights of its citizens abroad. Being outside of the state, the person does not lose communication with the state of the nationality. This principle is enshrined in the Vienna conventions on diplomatic (1961) and consular (1963) relations.

\footnotetext{
${ }^{4}$ Chornous Julia Theory and practice of forensic support of pre-trial investigation in cases of crimes of international character: monograph. NATs. Acad. EXT. cases'. Kiev: SKIF, 2012. $447 \mathrm{PP}$.
} 
International legal norms in the field of international cooperation in the fight against crime are:

- multilateral conventions for the fight against international crimes and crimes of an international character;

- treaties on legal assistance in criminal cases;

- treaties regulating the activities of relevant international organizations.

These include, for example, the international Convention of 14 December 1973. On the prevention and punishment of crimes against internationally protected persons, including diplomatic agents, the Convention on the non-application of the Statute of limitations to war crimes and crimes against humanity of 26 November 1968, the Convention on the laundering, detection, seizure and confiscation of the proceeds of crime (Strasbourg, 8 November 1990), etc.

The CIS countries have an Agreement on cooperation in combating economic crimes (Moscow, April 12, 1996), a Decision on joint measures to combat organized crime and other dangerous types of crimes on the territory of the CIS member States (Moscow, March 12, 1993), and others ${ }^{5}$.

Cooperation of States in the fight against crime is carried out on a multilateral (within the framework of international organizations) and bilateral basis. Thus, the sessions of the General Assembly and ECOSOC deal with various issues of combating crime. The UN Congresses on crime prevention are regularly convened (once every 5 years); the UN Committee on crime prevention and control meets once every 2 years; the office for crime prevention and criminal justice of the UN Secretariat is constantly functioning.

Bilateral agreements set out more specific forms of cooperation in combating certain types of crimes.

\section{Legal basis of cooperation in the fight against certain types of crimes}

We already know from the previous topics of the training course "International law" that an international offence is an act or omission of a subject of international law that violates the norms of international law and international obligations of that subject and causes material or non - material damage to another subject or group of subjects of international law or to the international community as a whole.

\footnotetext{
${ }^{5}$ International police encyclopedia: a conceptual framework. Conceptual approach. Theory and practice: In 10 vols. edited by Y. Rymarenko [and others], NAT. Acad. EXT. Affairs of Ukraine, Institute of state and law. V. Koretsky NAS of Ukraine, Acad. right. Sciences of Ukraine, Acad. ruko. Federal police. Republic Of Germany, Member Of The Academy. UPR. M-VA EXT. del Grew. Fader. Kiev: Publishing house "In Jure", 2003.
} 
Thus, from a legal point of view, an international offense is a complex legal phenomenon, and has the following characteristic main features:

- international public danger;

- wrongfulness;

- causal relationship between the wrongful act and harmful consequences;

- punish ability.

International public danger is the ability of an international offence to cause or damage international relations protected by international law. The wrongfulness of the offence is due to the violation of the mandatory rules of conduct enshrined in international legal acts. Causation is an important feature of the offense, as it allows you to find out that the cause of the harm is the cause of the offense. Punish ability is a legal consequence, a natural result of the offense. In an international offense, its composition is a set of objective and subjective features, based on which the subjects of the IP bear international legal responsibility.

The structure of an international offense includes:

- the object of an international offense is certain benefits of a material or intangible nature (international law, the system of international relations, human rights and freedoms);

- the objective side of an international offense is manifested in the form of an act of the subject of international relations, which violates the relevant international legal obligations;

- the subjects of an international offence are the States as the main subjects of the IP;

- the subjective side of the international offence consists in the relation of the subject of the MP to the act committed by him and its consequences and manifests itself in the form of guilt.

In modern international practice and doctrine, there are three types of international offenses, determined by the subject and subjective side of the composition of such offenses:

1. International crimes;

2. Crimes of an international character;

3. Other international offences (international torts) ${ }^{6}$.

International crimes are crimes that violate international obligations, which are fundamental to the vital interests of the international community, and are considered crimes by the international community as a whole

\footnotetext{
${ }^{6}$ Mironova V. problems of criminal responsibility for violation of laws and customs of war: monograph. Acad. right. Sciences of Ukraine. Kharkiv: Pravo, 2007. 152 p.
} 
(infringe on international peace and security, threaten the foundations of international law and order).

International crimes include:

a) war crimes;

b) crimes against peace and humanity (humanity);

c) aggression; genocide, ecocide.

The fight against these crimes is the competence of the UN Security Council, which bears the primary responsibility for the maintenance of international peace and security and acts on behalf of all UN member States. The subjects of international crimes are, first, States, as well as individuals acting on his behalf and personally committing such crimes. The international legal acts that establish the legal basis for combating international crimes are: the Convention on the prevention and punishment of genocide of 9 December 1948, genocide refers to acts committed with the intention to completely or partially destroy any national, ethnic, racial or religious group of people; genocide manifests itself in four forms -1 . Physical destruction, 2. - Socioeconomic genocide, 3. - Biological (deprivation of motherhood), 4. - National-cultural.); UN General Assembly resolution "on extradition and punishment of war criminals" of 13 February 1946; Convention on the nonapplication of the Statute of limitations to war crimes and crimes against humanity of 26 November 1968 and the like.

Crimes of international character on object of encroachment and degree of public danger differ from the international crimes. These are offences committed by individuals or groups of persons that infringe not only on the national but also on the international legal order, posing a public danger to two, several or all States, as well as international organizations.

These include:

- terrorism;

- distribution and trafficking in drugs;

- counterfeiting of banknotes and their sale (counterfeiting of banknotes);

- piracy;

- hostage-taking;

- computer crimes;

- human trafficking;

- hijacking of aircraft and the like.

The cooperation of States in combating crimes of an international character is regulated mainly by multilateral agreements (conventions), each of which is devoted to a specific crime. Conventions generally contain:

a) a normative definition of the offence; 
b) an obligation on the part of the state party to enshrine the Convention in national law (implementation);

c) an obligation on the part of States parties to extend their jurisdiction to the offences concerned.

In particular such international legal acts governing the legal framework for cooperation in combating international crimes are: Montreal Convention for the suppression of unlawful acts against the safety of civil aviation of 23 September 1971; Convention for the suppression of unlawful acts against the safety of Maritime navigation, 10 March 1988; international Convention against the taking of hostages of 17 December 1979; the UN Convention against illicit traffic in narcotic drugs and psychotropic substances of 19 December 1988.

International torts are defined on a residual basis; they include offences that are not included in the first two groups. These include:

- violation by the state of its unilateral obligations;

- failure to comply with the decisions of international courts and arbitration;

- violation by the state of Treaty obligations, are not of primary importance.

In the modern city, shadowy interregional and transnational criminal structures have formed and are gaining momentum, which commit unprecedented theft of money and material values from economic entities, receive super profits from socially violent crimes, such as illegal trade in Antiques, weapons, people, cars, drug and porn business (drug trafficking is 500 billion US dollars). Among the most dangerous manifestations of transnational criminal groups are the following:

1. International terrorism.

2. Committing a series of the most dangerous crimes (this is the Commission of custom theft, murder, robbery) and the return of criminals to their countries.

3. Legalization of criminal proceeds (purchase of enterprises, shares, etc.).

4. Computer criminal operations with money on accounts of domestic and foreign banks. Penetration into databases of confidential information.

5. Forgery of money and documents.

6. Evasion from payment of the established taxes.

7. Counteraction to investigation of crimes (counteraction to extradition).

8. Crimes against intellectual property.

9. Price manipulation on international and national exchanges.

10. Credit card fraud. 


\section{Environmental crimes ${ }^{7}$.}

Terrorism has become an integral part of the world's political and economic processes and poses an increasing threat to public and national security. From solitary manifestations, it has become a mass phenomenon. Modern terrorism takes the form of:

1) international terrorism (terrorist acts of international scale);

2) domestic political terrorism;

3) criminal terrorism, from mercenary motives;

4) state terrorism.

The very word "terror" is borrowed from Latin and means "fear", "horror". Terrorism is a method or achievement whose fundamental basis is the use or threat of violence. Violence is not the primary goal of terrorism, as opposed to a simple deliberate political assassination. A terrorist act, first, serves as a kind of message, a sign.

One of the most serious and most dangerous international crimes is international terrorism, which is characterized by the following features:

a) the preparation of the crime is in the territory of one state, and is carried out on the territory of another state;

b) committed a crime on the territory of one state, the terrorist, as a rule, is hiding on the territory of another state (the question of extradition).

Acts of international terrorism include cruelty, murder, hostage-taking, hijacking, torture or threats of torture, for political purposes when directed:

1. In respect of any foreign government, international organization or their representatives;

2. In respect of any citizen of a foreign state, only for being a citizen of that state.

3. When such acts are committed by a person crossing the state border of the country that requires his extradition.

After the Second world war, the problem of combating terrorism is dealt with by the UN. Thus, on 14 December 1973, the Convention on the prevention and punishment of crimes against internationally protected persons, including diplomatic agents, was adopted. The persons referred to in the Convention include:

- the head of state, the Minister of foreign Affairs (during their stay in a foreign state);

- representatives of international organizations, diplomatic agents.

${ }^{7}$ International legal assistance and cooperation in criminal proceedings of Ukraine: ZB. dock.: In 2 h. / way. I. Kogutich; LNU. Of Ivan Franko. Department of criminal procedure and criminalistics. Lviv, Triada plus, 2004 . Part 1. 2004. 940 p. 
States parties to the Convention have undertaken to cooperate in the prevention of crimes and to provide assistance and assistance in the investigation and punishment of crimes.

The European Council adopted the Convention for the suppression of terrorism in 1976, which regulates two categories of offences:

a) acts which States recognize as criminal by virtue of their participation in the Convention (illegal seizure of aircraft, attempt on the life and freedom of persons entitled to international protection, taking hostages and arbitrary deprivation of liberty, etc.);

b) acts which are recognized as criminal at the discretion of States (acts of violence, which are an attempt on the life and freedom of individuals; serious actions against property and creating a danger to people).

Distribution and drug trafficking is a crime that infringes not only on the life and health of the individual, but also at undermining the country's economy, foreign economic ties between the two countries, for their peaceful cooperation. In 1961, a single Convention on narcotic substances was signed, in 1971 - the Convention on psychotropic substances, and in 1988 - the UN Convention against illicit traffic in narcotic substances and psychotropic substances.

Under these conventions, the production, possession and distribution of narcotic and psychotropic substances, as well as their sale, purchase, import and export, are criminal offences. The fight against the proliferation and trafficking of drugs is an internal matter for each state, most of which have adopted national laws providing for severe penalties. Each state may establish its jurisdiction when the alleged offender is in its territory (art. 4). The 1988 Convention regulates in detail questions of mutual legal assistance in investigation, in criminal prosecution and trial of the corresponding offenses (art. 7).

The main international bodies exercising control over narcotic and psychotropic substances are:

The Commission on narcotic substances (CNS), which determines the list of narcotic substances to be controlled; makes recommendations for scientific research; promotes the implementation of international agreements and drafts new agreements, etc.;

The international narcotics control Board (INCB), composed of 13 experts elected by ECOSOC in their personal capacity for a five-year term, monitors countries 'compliance with drug treaties; requests States' annual production, consumption, import and export of drugs; monitors drug trafficking, etc.

Counterfeiting and distribution of banknotes is an international crime. The elimination of this crime requires the efforts of many States. In 1929, 
the Convention for the suppression of counterfeiting of banknotes was signed, according to which States undertook to prosecute those who either moonlights, falsifies banknotes, distributes counterfeit signs, participates in the manufacture or sale of other items intended for counterfeiting. Persons are brought to responsibility regardless of what country they produce counterfeit banknotes. The Convention contains a provision on the extradition of criminals to the state concerned.

Human trafficking is a serious crime. This crime covers the slave trade, trafficking in women (inducement to prostitution) and children. The most important international instruments prohibiting the trade in slaves are the slavery Convention of 1956, the Supplementary Convention on the abolition of slavery, the slave trade, institutions and practices similar to slavery (forced labour).

In 1970, States signed the Convention on the suppression of trafficking in women, which contained the obligation of States to punish such acts as incitement to prostitution by deception, violence, threat; provided for the punishment of perpetrators and their extradition at the request of the state concerned ${ }^{8}$.

Piracy is an international crime. According to the UN Convention on the law of the sea 1982, piracy is understood as:

a) any unlawful act of violence, or any robbery committed with the crew or passengers of a ship (aircraft);

b) any act of voluntary participation in the use of a ship (aircraft) in order to carry out the above actions;

The Convention obliges all States to cooperate in the suppression of piracy on the high seas, or in any other place outside the jurisdiction of any state (art.100). Any state may seize a pirate ship (aircraft), arrest its crew, seize the property on it (article 105). The seizure of a ship for piracy may be committed only by a military or a ship by a military aircraft, consisting in the public service and specially authorized for that (article 107). No state should provide safe haven to pirate ships and their crews. Pirate vessels under any flag and with any national crew may be pursued on the high seas, captured and, in case of resistance, sunk by warships of any power. When a pirate ship is captured, its crew is punished according to the laws of the capturing state (article 105). The vessel and property are confiscated by the invading state and returned to their rightful owners.

8 Demchenko I., Soloviev A. Prevention of the spread of counterfeit drugs at the international and national level: monograph / I. Demchenko, A. Soloviev. Kiev: the new press, 2014. $128 \mathrm{~s}$. 
In order to combat the seizure of aircraft, States adopted the Convention for the suppression of unlawful seizure of aircraft at The Hague in December 1970. The Convention establishes that any person on Board an aircraft in flight who unlawfully, by violence or threat of violence, seizes that aircraft or exercises control over it commits an offence. Every state has committed itself to apply in relation to such offence with severe penalties. The main objective of the Convention is to ensure the inevitability of punishment of persons guilty of illegal seizure of aircraft. The motives for such actions are not considered a circumstance that absolves the offender from responsibility.

The Convention refers to the possibility of extradition of the offender to the state concerned and establishes that each state may consider the Convention as a basis for extradition. However, the Convention does not provide for the mandatory extradition of persons who have committed an unlawful seizure of an aircraft. The state in whose territory the offender is found, if it does not extradite him, is obliged to punish him severely in accordance with its national legislation.

The Convention also provides that the authorities of the state in whose territory the hijacked aircraft landed must return the aircraft, cargo, passengers and crew to the state concerned immediately. The provisions of the Convention should apply to all cases of unlawful seizure of aircraft, both in international traffic and in domestic flights.

Fight against illegal activities with radioactive substances. The 1980 Convention on the physical protection of nuclear material was adopted to ensure the physical protection of nuclear material used for peaceful purposes and in transit, as well as nuclear material used for peaceful purposes in use, storage and transport within a state. The Convention has Annexes I and II. Annex I defines the levels of physical protection of nuclear material in international transport. Annex II classifies nuclear materials in detail.

One of the important steps in the fight against crime is to prevent the possibility of legalization of proceeds of crime and ensure their confiscation. Ukraine is a party to several agreements providing for a Set of measures to prevent the "laundering" of criminal proceeds. These include the UN Convention against illicit traffic in narcotic drugs and psychotropic substances of 1988, the Council of Europe Convention on money laundering, detection, seizure and confiscation of proceeds from crime (Strasbourg, November 8, 1990) and a number of others.

The 1990 UN General Assembly resolution defines proceeds of crime as any property obtained or realized, directly or indirectly, because of the Commission of an offence or the value of property or other benefits derived from the Commission of an offence. 
States undertake to take all measures to confiscate the instruments of crime and illicit proceeds and, in particular, to identify and search for the valuables to be confiscated and to prevent any or all alienation of these valuables ${ }^{9}$.

Courts and other competent authorities of States parties to the Convention should have the right to seize financial or other documents (no reference to Bank secrecy is allowed; however, the requested state may require that a request for cooperation requiring the removal of Bank secrecy be confirmed by a judicial authority).

Upon receiving a request for confiscation of objects or tools, the state must present it to its competent authorities. Confiscation may be refused if:

- the legislation of the requested state does not provide for confiscation for this offence;

- there is no property that is the subject of confiscation; - the Statute of limitations has expired.

The States parties to the Convention shall designate a Central authority responsible for sending, receiving and executing requests for legal assistance in such cases and shall notify the Secretary-General of the Council of Europe thereof. As a rule, most States have such a body as the Prosecutor's office.

\section{Institute of extradition in public international law (extradition)}

The adoption by the UN international law Commission at its 43rd session in 1991 of the Code of crimes against the peace and security of humankind became an essential factor of conceptual and practical order in the process of formation of an integral and modern system of international law.

Within the framework of the studied question, the provisions of article 6 of the Code "Obligations to transfer to the court or to extradite to another state" are of undoubted scientific and practical interest. It says:

1. The state in whose territory a crime against the peace and security of mankind has been committed shall transfer it to the court or extradite it to another state.

2. If extradition is requested by more than one state, special attention shall be paid to the request of the state in whose territory the offence was committed."

The resolution of article 6 of the Code is a classic example of the application of the principle «either extradite or punish". This principle brings us to the immediate subject of our study - the institution of extradition.

\footnotetext{
${ }^{9}$ Mechanisms of law enforcement cooperation in the process of detection and investigation of crimes related to human trafficking: studies / Amer. Assoc. international initiative on the rule of law (ABA / ROLI); podgot.: Marina Elefante, Ludmila Ilkovic. Kiev, 2010. $39 \mathrm{sec}$.
} 
The importance of the institution of extradition in the implementation of international criminal justice is confirmed by the adoption without a vote (that is, by consensus) on 14 December 1990 at the 45th session of the UN General Assembly (resolution 45/116) of the model Treaty on extradition. The legal act establishes the types of offences for which extradition may be applied.

Extradition treaties perform an important function of international criminal justice ensuring the principle of inevitability of punishment for the whole range of criminal, international and international crimes.

There is no single definition of extradition. In the monograph of the scientist G. M. Valeev, extradition should be understood as an act of legal assistance based on international treaties and generally recognized norms and principles of international law, which is expressed in the transfer of the accused or convicted by the state in whose territory he is, to the state in whose territory the person committed the crime or whose citizen he is, or to the state that the victim of the crime, to bring him to criminal responsibility or to enforce the sentence.

The very term "extradition" comes from Latin and means the forcible return of this person to his sovereign.

Extradition (extradition - transfer) is a transfer from one state to another on its request or the request of the person who committed an international crime or crime of international character is suspected of committing such offence, to bring it to legal liability or coercion made against her court verdict ${ }^{10}$.

Scientific and theoretical definition-extradition should be understood as a process that is based on international treaties, generally recognized principles of international law, norms of domestic law and is associated with the provision of legal assistance by States, consisting in the transfer of a suspect, accused or convicted by the state in whose territory he is, the state in whose territory he committed a crime or a citizen of which he is, or the state that the victim of the crime, to bring him to criminal responsibility or to execute the sentence of the court.

The European Convention on extradition 1957, the first in world practice introduced a fairly complete mechanism for the implementation of the Institute of extradition (extradite) persons and a number of procedural safeguards rights of a person, which is issued to conduct the preliminary investigation or judicial proceedings with respect of the offense committed.

${ }^{10}$ Using the capabilities of the NCB Interpol in Ukraine in the fight against crime: studies. manual / V. Nekrasov [et al.]. Kyiv: KNT: SKIF, 2008. 163 p. 
A state may extradite an offender if it and another state have entered into a relevant Treaty (extradition Treaty or legal aid Treaty). In the absence of such a Treaty, the state shall, in accordance with its domestic law, decide on the extradition or non-extradition of the offender.

Extradition of criminals occurs in the presence of:

1 - legal basis (legal provisions in national law, bilateral treaties for extradition or legal assistance in criminal matters, international agreements on the fight against certain types of international crimes, international crimes);

2 - terms of issue (the act provided for by the Treaty on extradition; it is defined in the criminal law of the two States and provides for the punishment, the upper limit of which exceeds one year of imprisonment or more severe punishment; the person seems to be sentenced only for the offense; the death penalty will not be applied if it is not provided for by the laws of the issuing state).

The procedure for extradition includes:

- sending a request or petition for extradition;

- taking the offender into custody;

- negotiating extradition through diplomatic channels;

- extradition in accordance with the instructions of the competent authorities of the party, which issues in the prescribed manner with reimbursement of expenses incurred.

The issuance is not subject to:

- nationals of the requested country (private citizens) or the person is in this state, the right of asylum;

- in cases of private prosecution or political crimes (war criminals and perpetrators of crimes against humanity are not political criminals, in accordance with resolutions of the UN General Assembly);

- while committing a felony in the state of stay (pending a relevant court decision or sentence);

- if the person suffered a criminal punishment for the crime or was acquitted by the court;

- in connection with the expiration of the Statute of limitations, or the proceedings were closed on a legal basis;

- the threat of application to the offender of unlawful measures of mental or physical influence.

In international law, there are three types of extradition: - extradition of a person for criminal prosecution; - extradition of a person for the purpose of execution of punishment; - temporary extradition.

Extradition of persons for criminal prosecution or execution of punishment. 
Under legal aid treaties, a person can be extradited for any crime, not just specific crimes of an international character. The results are produced only for acts which under the laws of both parties punishable by imprisonment for a fixed term (usually over one year) or a stricter punishment (that is, under those conditions which we considered earlier).

Specific issues of extradition of criminals is regulated between the States concerned. Thus, on May 27, 1993, Ukraine and the Republic of Poland signed an Agreement on legal assistance and legal relations in civil and criminal cases, according to which the parties undertook (art.60 to extradite each other at the request of persons located in their territory, for the purpose of criminal prosecution or execution of punishment).

The extradition of a person to carry out a sentence consists of the transfer of a person who has been convicted by a foreign court and has absconded from serving a sentence, but has been detained in the territory of another state. The application for extradition shall be accompanied by a certified copy of the sentence that entered into force, certified in the appropriate manner (usually by the Ministry of justice) on the basis of which the person was convicted.

If the person in respect of whom the request for extradition is filed is brought to criminal responsibility or is serving a sentence for another crime in the territory of the requested party, his temporary extradition may be carried out at the reasonable request of the requesting party. The temporarily extradited person, after carrying out the procedural actions for which he was extradited, must be returned.

\section{International criminal police organization (Interpol)}

The international criminal police organization - Interpol (IOCP Interpol) was established on September 7, 1923 by the decision of the International police Congress, which was held in Vienna, Austria.

Today, the working body of Interpol is the General Secretariat (Lyon, France).

Interpol includes General Assembly, Executive Committee, General Secretariat, National Central Bureau, Advisers.

The General Assembly is the highest organ of the Organization. One or more delegates may represent each member. However, the delegation of each country should have only one leader appointed by the competent governing body of that country.

The functions of the General Assembly include:

- to fulfil the obligations stipulated by the Charter; define the principles of and General measures, which should contribute to the goals of the organization; to consider and approve the overall work plan, which is 
submitted to the General Secretary for the next year; to install other necessary rules; to choose individuals to perform functions under the Charter; to take decisions and make recommendations to Members on matters within its competence; determine the financial policies of the organization; consider and approve agreements with other organizations.

Only one delegate from each country has the right to vote. Decisions are taken by a simple majority of votes, except for those for which the Charter provides for a majority of $2 / 3$ of the votes.

The Executive Committee consists Of the President of the Organization, three Vice-Presidents and 9 delegates.

The General Assembly elects from among its delegates a President (for 4 years) and three Vice-Presidents (for 3 years).

The President: - presides over the sessions of the General Assembly and of the Executive Committee and direct the discussion; oversees that the operations of the Organization consistent with decisions of the General Assembly and Executive Committee; maintains constant communication with the Secretary-General of the Organization.

The Executive Committee: monitors the implementation of the decisions of the General Assembly; prepares the agenda of the sessions of the General Assembly; submits to the General Assembly a work plan and proposals as it deems appropriate; monitors the activities of the Secretary-General; exercises all powers delegated to it by the Assembly.

The permanent services of the Organization constitute its General Secretariat.

The General Secretariat implements the decisions of the General Assembly and the Executive Committee, acts as an international Centre for combating common crime; provides effective administrative management of the Organization; maintains relations with national and international bodies; prepares the necessary publications, etc.

The General Secretariat consists of the Secretary-General, specialists and administrative staff. The Secretary-General shall be nominated by the Executive Committee and approved by the General Assembly for a term of 5 years.

The Organization may consult with Advisors on scientific matters. The Executive Committee appoints advisers for a period of 3 years from among internationally known people in the field of activity that interests the Organization $^{11}$.

However, the history of this organization begins much earlier.

${ }^{11}$ Bandurka O. Interpol: international criminal police organization: sci.- pract. manual / O. Bandurka; national UN-t of internal Affairs. Kharkiv: Osnova, 2003. 323 p. 
In the late XIX - early XX century, before law enforcement agencies around the world increasingly began to appear issues of search and detention of persons who have committed crimes and hiding from criminal responsibility abroad. The realities of public life, namely the development of economic, political and social ties between States, contributed to the integration of crime at the international level. It was then that there was a need to establish an international police organization to ensure proper cooperation of law enforcement agencies of different States in the fight against international (or transnational) crime.

1889 the founding meeting of the international criminal law Union was held. The participants noted the emergence of international crime and called on the police of different countries to take concerted action to overcome it. At the same time, there were proposals to bring under police Cooperation a permanent, institutionalized base - first at the national and then at the international level.

1905 at the international conference of criminalists of the Germanspeaking countries the next attempt to unite efforts in fight against the international crime is made. At its 10th international Assembly in Hamburg, the criminologists, on the proposal of the French-speaking States, adopted a resolution confirming that the increased demand for tourism and foreign travel contributes to the emergence of new forms of international crime. Thus, joint international efforts are needed to overcome it. It was therefore planned to establish national Central bureau within police units to exchange information on international crime and to improve direct police relations.

The problems of combating international crime were discussed at many conferences and congresses: 1905. (Buenos Aires), 1909 (Madrid), 1912 (Sao Paulo) and 1913 (Washington).

In 1914, Monaco hosted the first international Congress of criminal police, represented by experts from Austria, Great Britain, Italy, Russia and France. There were four items on the agenda of the Congress:

1. Unification of the procedure for extradition of criminals;

2. International preventive anthropometry;

3. Creation of the Department for accounting of international criminal information;

4. Development of measures to speed up and simplify the arrest of criminals.

In subcommittees, police officials discussed technical issues related to the protection of police officers, the adoption of the international police code, etc.

The first section dealt with the General problems of the police. The second and third are separate issues of the work of the international police 
and peculiarities of the legislation of different countries. The participants of the forum asked the government of Monaco to take the initiative to establish international commissions in Paris to develop unified standards of identity cards and to organize a single international Bureau for the identification of international crimes. At the same time, they agreed to meet two years later in Bucharest at the Second international Congress of criminal police. However, during the First World War, not only these hopes, but all the resolutions adopted in Monaco, have sunk into oblivion.

After the First World War, the same problem was on the agenda international crime, but in a more acute form. The morality of wartime has affected-the crime rate has sharply increased, in particular, based on drug addiction and alcoholism. Therefore, the issue of combining the efforts of the criminal police against crime at the international level has acquired special relevance ${ }^{12}$.

In September 1923, the international police Congress was held in Vienna (Austria), represented by all continents except Australia. Criminologists, criminologists and diplomats attended it from Austria, Belgium, Denmark, Egypt, Greece, Italy, Latvia, Lithuania, the Netherlands, Germany, Poland, Romania, the United States of America, Turkey, Hungary, France, Czechoslovakia, Switzerland and Sweden.

One of the resolutions of the Congress established the International criminal police Commission (ICCP), with its first official headquarters in Vienna, which immediately began work on its program of action (so, September 7, 1923. considered the date of birth Of the international criminal police organization - Interpol). In 1924, the ICCP adopted a resolution on five important issues that determined the direction of development for many years to come, namely: the establishment of information offices for the collection of facts of international crime; the development of evidence systems and the international search for criminals; organization offices to identify individuals at a distance; the newspaper of the international police; the creation of the overall program to prevent and detect counterfeit banknotes and documents.

1930 ICCP developed the principles of extradition.

In March 1938, German troops occupied Austria, and 18 months later, the Second world war began. The activities of the ICCP were curtailed.

Since 1940, the chief of the German security service, Heydrich, headed the ICCP. The ICCP administration was transferred to Berlin.

${ }^{12}$ Gritsaenko L. Bodies of the European Union on fight against crime and legal bases of their cooperation with Ukraine. Bulletin of The national Academy of Prosecutor's office of Ukraine. 2012. No. 1. P. 91-95. 


\section{During the Second World War there has been no official Congress of the ICCP.}

1946 representatives of 17 States in response to the call of the Belgian government met in Brussels to re-establish the international criminal police Commission. It was decided to move its headquarters to Paris (France). 19 countries resumed their participation in the ICCP, among them Belgium, Chile, Czechoslovakia, Denmark, Egypt, France, Greece, Iran, Luxembourg, Netherlands, Norway, Poland, Portugal, Turkey, Sweden, Switzerland, Yugoslavia, United Kingdom and United States of America.

It should be noted that for the first time the word "Interpol" (as well as the modern sign - symbol of the Organization) in 1914 appeared on the pages of the "Journal de Monaco" in an article about the First international Congress of criminal police. And since July 22, 1946 is used as a Telegraph designation of the address of the headquarters in Paris.

1956 in Vienna on anniversary 25th session General Assembly ICCP adopted Charter Organizations, in UF. 1, which referred, that henceforth international Commission criminal police will be called International organization criminal police (IOCP) - Interpol. The Charter provides for cooperation at the world level, before that-the influence of the Organization extended mainly to European States. 1989 its headquarters was relocated to Lyon (France).

Consequently, three very important changes have taken place during the existence of the ICCP.

First, it has spread to the whole world because of the accession of new members.

Second: in 1956, the international criminal police Commission was renamed the international criminal police organization - Interpol.

Third, the Statute of Interpol has been adopted, which is still in force, practically unchanged.

The main tasks and goals of Interpol, according to the Charter:

- ensuring broad cooperation between the criminal police authorities concerned within the framework of the current national legislation of the member countries of Interpol and in strict accordance with the provisions of the world Declaration of human rights;

- creation and development of all necessary bodies that will be effective in combating common crime.

Under the Statute, Interpol does not engage in or interfere with activities of a political, military, religious or racial nature.

The cooperation of police authorities within Interpol is based on the actions applied by these authorities in their countries and in strict accordance 
with their national legislation. All Interpol member countries have equal rights regardless of their financial contributions.

Currently, 187 countries of the world are members of the international criminal police organization - Interpol.

The history of the Working apparatus of the Interpol Ukrbyuro.

After the Declaration of independence, Ukraine needed constant, prompt and effective international cooperation, as well as attracting advanced foreign experience for the development of its own law enforcement system and combating transnational organized crime.

Given the lack of relevant experience, the first steps in this area were not easy.

The possibility of Ukraine's accession to the international criminal police organization was studied in April 1991, when the Ukrainian Republic was part of the USSR.

Immediately after independence, at the initiative of the Ministry of internal Affairs of Ukraine, supported by the Ministry of justice, Ministry of foreign Affairs and the security Service, on behalf of the Government was submitted to the General Secretariat of Interpol on Ukraine's accession to the Organization.

Ukraine's admission to Interpol took place on 4 November 1992 at the 61st session of the Interpol General Assembly (Dakar, Senegal). From Ukraine, the session was attended by a delegation, which included the first Deputy Minister of internal Affairs of Ukraine Vladimir Mikhailovich Korneychuk and chief Of staff of the Ministry of internal Affairs Alexander Mikhailovich Ishchenko.

After gaining membership in Interpol, there was an urgent need to create a unit that would directly provide the function of the national Central Bureau of Interpol in Ukraine. To this end, the interior Ministry created a temporary working group to interact with Interpol, the head of which was appointed Pyotr Melnik ${ }^{13}$.

The working group included employees of the Ministry Grigory Stelmakh, Igor Limarchenko, Oleg Kaplin, Zinaida Verbenko and others.

These people have done a tremendous job and in fact created the Foundation for the further development of the Ukrainian Bureau of Interpol.

In addition, already on March 25, 1993, according to the obligations provided by the membership of the state in the Organization, by the decision of the government of Ukraine the national Central Bureau of Interpol was

\footnotetext{
${ }^{13}$ Mironova V. problems of criminal responsibility for violation of laws and customs of war: monograph. Acad. right. Sciences of Ukraine. Kharkiv: Pravo, 2007. 152 p.
} 
created. On this day, the "Regulation on the National Central Bureau of Interpol" was also approved.

Participation of employees of Ukrburo together with representatives of law enforcement agencies of Ukraine in international events of IOCPInterpol made possible the exchange of experience with foreign colleagues in the fight against crime.

The national Central Bureau of Interpol (Ukrburo Interpol) represents Ukraine in Interpol and is the center of coordination of interaction of law enforcement agencies of the country with the competent authorities of foreign countries in the fight against crime, which has a transnational character or goes beyond the country.

The powers of the Ukrburo of Interpol are assigned to the Ministry of internal Affairs, within which the working apparatus of the Bureau is created.

The main objectives of Ukrbyuro of the Interpol are: - coordination of activities of law enforcement agencies in the fight against crime, which is transnational in nature or outside the country; - ensuring interaction with the General Secretariat and the relevant bodies of the member States of Interpol in the fight against crime; - assessment of the level of acceptance in Ukraine of crime having a transnational character, and threats of criminal activity of citizens of Ukraine abroad.

In order to determine the evidence-based state policy against crime and to develop recommendations and proposals to combat crime that has a transnational nature or goes beyond the country, the Interpol Ukrburo may turn to advisers who perform exclusively Advisory functions on a contractual basis.

The Ministry of internal Affairs in coordination with the Ministry of justice and the security Service determines the composition of advisers.

The working unit of Ukrbyuro Interpol is an independent structural subdivision of the Central apparatus of the interior Ministry, headed by its Director appointed by the President. The Minister of internal Affairs approves the structure and staff of the working apparatus.

According to the legislation of Ukraine, the activity of the Ukrainian Bureau of Interpol consists in the organization of information support of criminal and operational-search cases, which are in the production of law enforcement agencies of Ukraine and foreign countries.

Of Ukrbyuro of Interpol, in particular, provides:

- exchange of information between law enforcement agencies of Ukraine and foreign States during the proceedings on the relevant criminal and operational-search cases in order to organize the necessary checks and operational-search activities; 
- international search for accused and defendants who are hiding from law enforcement agencies in order to evade criminal responsibility and are on the state or interstate wanted list; organizes the extradition of such persons.;

- search for missing persons, search for victims of human trafficking, search for stolen vehicles, cultural property and Antiques, identification of persons and unidentified corpses, etc.;

- exchange of analytical and statistical information on the fight against crime and the organization of law enforcement agencies.

Department of international investigation and extradition.

The Department of international investigation and investigation support of the working apparatus of the Ukrburo Interpol since 2008 includes the Department of international investigation and extradition, which currently has seven certified employees. The main task of this unit follows from its name, that is, the organization of international search on the territory of all member countries of Interpol, as well as the extradition of criminals from Ukraine and to Ukraine. Actual for the specified division also is activity on placement of cards in the international information system of Interpol ASF, and also accumulation, systematization and the analysis of information of criminal character concerning physical and legal persons, criminal groups, tendencies of development of transnational crime. Collection and analysis of information concerning persons and organized criminal groups involved in the Commission of serious and especially serious crimes in order to enter this information into the databases of the Working apparatus and the General Secretariat, as well as initiating a ban on their entry into the territory of Ukraine and expulsion from its borders.

Besides the already noted the staff of the Department of international fugitives and extraditions in their daily work, study and generalize the advanced world experience in the organization of the international investigation and extradition, participate in discussion forums on issues related to the competence of the Department, and provide practical assistance to law enforcement agencies of Ukraine and other member countries of Interpol in investigating and solving transnational crimes ordinary orientation.

The Department of international investigation and extradition of the Interpol Ukrburo interacts with law enforcement agencies of Ukraine, Central and local government authorities, governing bodies and divisions of Interpol, law enforcement agencies of foreign countries in the performance of its tasks.

International agreements on extradition and mutual legal assistance play an important role in carrying out the tasks assigned to the international 
investigation and extradition division. These agreements are an effective means of cooperation in the fight against criminal offences.

At the end of 1994, according to the plan of technical modernization of the General Secretariat of Interpol, Ukrburo was equipped with a modern communication system, which significantly improved the exchange of information between Ukrainian law enforcement officers and foreign colleagues.

Important events in the early formation of Ukrbyuro Interpol were the visits to Ukraine of high-ranking officials of the International criminal police organization - in January 1996, the President of Interpol Mr. Bourne Erickson (representative of police of Sweden) and in May of the same year Secretary-General Mr. Raymond Kendall (police UK).

Ukrburo Interpol in the period from 1996 to 2009.

During this time, the heads of the division were Viktor Radetsky (1996-2001), Alexander Chemenko (2001-2002), Nikolai Dzhiga (2002-2003), Stanislav Denisyuk (2003), Viktor Zubchuk (2003-2004), Anatoly Slipchenko (2004-2005), Kirill Kulikov (2005-2007), Rostislav Vergeles (2007), Vasily Vladimirovich nevolya (2007 - by t/h).

An important stage of formation and development of Ukrburo Interpol was the period 1997-2000. In particular, in 1998 the staff of the Bureau was expanded, which allowed creating another part. Since then, the unit has been operating around the clock.

At that time, the systematized data banks of the Interpol Ukrburo were created, normative documents regulating the order of international cooperation between law enforcement agencies of Ukraine and Interpol were adopted, including: Manual on the use of law enforcement capabilities of National Central Bureau of Interpol in Ukraine in the prevention, disclosure and investigation of crimes approved by joint order of the Ministry of internal Affairs of Ukraine, General Prosecutor's office of Ukraine, security Service of Ukraine, State Committee for state border protection of Ukraine, State customs service of Ukraine, State tax administration of Ukraine from January 9, 1997 № 3/1/2/5/2/2.

In 2003, Mr. Ronald Kenneth noble, Secretary General of Interpol, visited Ukraine and held working meetings with the President of Ukraine, the interior Ministry and other law enforcement agencies of Ukraine.

The negotiations gave a significant impetus to the development of international law enforcement cooperation through Interpol channels. Firstly, the working apparatus of the Interpol Ukrburo was connected to the new telecommunication system Interpol I-24/7, secondly, the Secretary General raised the issue of the European Commission to provide international technical assistance to the Ukrainian division of Interpol, thirdly, the high 
assessment of the activities of the Interpol Ukrburo by the first person of the Organization in the future became a prerequisite for closer cooperation of law enforcement agencies of Ukraine with the Interpol General Secretariat.

Outstanding event.

Since 2003, cooperation between Ukrburo Interpol and the General Secretariat Of the organization has reached a new level. In particular, according to the agreement between the interior Ministry and the General Secretariat of Interpol, according to the relevant decree of the President and the Cabinet of Ministers of Ukraine had resolved the question about the direction of the representative of the Ministry of internal Affairs of Ukraine the General Secretariat of Interpol.

In 2004-2008, a number of Interpol international events were also held in Ukraine, in particular: the 33rd Interpol European regional conference (May 2004); the Interpol international seminar on countering bioterrorism (November 2006); the first Interpol international seminar on the use of DNA research in law enforcement (October 2008).

In addition, in the period from 2006 to 2008, the interior Ministry has taken measures on implementation of the international technical assistance project of the European Commission TACIS project "International cooperation in criminal matters, via Interpol". The budget of this project was 990 thousand euros.

According to the tripartite agreement, technical assistance was provided at the expense of the European Commission, the implementation of the project was carried out directly by the General Secretariat of Interpol, and the Ministry of internal Affairs of Ukraine was the recipient of this assistance.

Its main task was to comprehensively improve the activities of the Ukrainian Bureau of Interpol and international cooperation of law enforcement agencies of Ukraine within Interpol as a whole.

For two years, the project funds were:

- organized the participation of employees of the Working apparatus of Interpol Ukrburo and other departments of the Ministry of internal Affairs in international events held by Interpol;

- significantly updated the Park of computer and organizational equipment in the Working apparatus of Ukrburo Interpol;

- set up and equipped in the Kiev national University of internal Affairs classroom for training law enforcement officers of Ukraine and foreign countries to work with Interpol data banks, as well as the use of other Interpol capabilities in everyday activities in the detection and investigation of crimes. 
The peculiarity of the newly created classroom is that the computer equipment installed in it has direct access to the Interpol data banks located in the General Secretariat of the Organization through the Interpol - I-24/7 telecommunication system.

Today, the working apparatus of the Ukrburo of Interpol is a wellorganized, modernly equipped unit that is able to provide effective assistance to law enforcement agencies in conducting operational search and other activities abroad in cases of transnational crimes of a common criminal and economic orientation, in particular, human trafficking, money laundering, international drug trafficking, terrorism, cybercrime, in organizing an international search of persons and obtaining information from the data banks of the General Secretariat of Interpol, law enforcement agencies of other countries ${ }^{14}$.

With Ukrburo Interpol actively interact not only units of internal Affairs, and the Prosecutor General's office, security Service, State tax administration, state customs service, state border service, foreign intelligence Service.

However, the unit does not stand still and continues to develop. In particular, work is underway to improve the regulatory support for international law enforcement cooperation through Interpol channels: draft new regulations or amendments to existing documents are being prepared. Work is also continuing to improve the technical component in the activities of the unit, including the improvement of existing in Ukrburo electronic data banks, electronic document management and so on. In addition, in 2009, it was planned, together with the Kiev University of internal Affairs, to prepare and implement a training course for students of the University and practitioners of the internal Affairs bodies in working with Interpol data banks and using other opportunities of the Organization in everyday work during the detection and investigation of crimes.

\section{CONCLUSIONS}

Thus, international cooperation of States in the fight against crime is the cooperation of States aimed at the development and coordination of measures for the prevention, detection of crimes and treatment of offenders, as well as the development of comprehensive goals and objectives to minimize transnational and domestic illegal acts. It develops at three levels:

${ }^{14}$ Demchenko I., Soloviev A. Prevention of the spread of counterfeit drugs at the international and national level: monograph / I. Demchenko, A. Soloviev. Kiev: the new press, 2014. $128 \mathrm{~s}$. 
the level of bilateral cooperation between States; regional level; cooperation at the universal (global) level.

\section{SUMMARY}

When studying the topic and preparing for the lesson, it should be noted that the duty of cooperation of States directly follows from the UN Charter. It must be remembered that a successful fight against crime, especially that of an international nature, requires the coordination of the efforts of many States. It should be noted that the fight against crime is one of the most important internal functions of the state. An important point is that the internationalization of crime, the need to unite the efforts of States in the fight against it has given rise to a trend towards the internationalization of criminal law.

\section{REFERENCES}

1. Al-Batran Khaled Regulatory framework for countering international terrorism within the framework of the Organization of Islamic Cooperation: abstract. dis. ... Yuri. Sciences: 12.00.11. NATs. UN-t odes. Yuri. Acad. Odessa, $2012.17 \mathrm{p}$.

2. Bakay Martha Implementation of the provisions of the "anticorruption" conventions in the domestic criminal legislation: abstract. dis. ... Cand. Yuri. Sciences: 12.00.08. Kiev. NATs. UN-t im. Of Taras Shevchenko. Kiev, 2013.19 p.

3. Bandurka O. Interpol: international criminal police organization: sci.pract. manual / O. Bandurka; national UN-t of internal Affairs. Kharkiv: Osnova, 2003. $323 \mathrm{p}$.

4. Belotsky S. international legal regulation of peacekeeping: studies. benefit. for students. UNIVERSITY / S. Belotsky; Kiev. NATs. UN-t im. Of Taras Shevchenko. Kiev: Kiev. UNT, 2012. 287 p.

5. Using the capabilities of the NCB Interpol in Ukraine in the fight against crime: studies. manual / V. Nekrasov [et al.]. Kyiv: KNT: SKIF, 2008. $163 \mathrm{p}$.

6. Voronenko V. Problems of international cooperation in the sphere of countering nuclear proliferation and nuclear terrorism. Archive of clinical medicine. 2011. No. 2. P. 84-90.

7. Garbisa Dmitry International legal framework against corruption : author. dis. ... Cand. Yuri. Sciences: 12.00.11. NATs. Yuri. UN-t im. Yaroslav The Wise. Kharkiv, 2015. 22 sec.

8. Gritsaenko L. Bodies of the European Union on fight against crime and legal bases of their cooperation with Ukraine. Bulletin of The national Academy of Prosecutor's office of Ukraine. 2012. No. 1. P. 91-95. 
9. Demchenko I., Soloviev A. Prevention of the spread of counterfeit drugs at the international and national level: monograph / I. Demchenko, A. Soloviev. Kiev: the new press, 2014. $128 \mathrm{~s}$.

10. Information technologies of fight against terrorism: materials of Sciences.- pract. Conf. Kiev, 15 Jul. 2012 / Acad. no. of education of Ukraine, Global acad. of alled leadership, Acad. of open society security. Kyiv: Lipan O. vid., 2012. 91 p.

11. Kulichenko O. Interpol. Evolution of the structure and activities: monograph / O. Kulichenko. View. 1-E. Kirovograd: RVV KDPU im. Vladimir Vinnichenko, 2013. 175 p.

12. Kutsevich Maxim criminal liability for ecocide: international and national aspects: monograph / M. Kutsevich; Kyiv national University. Of Taras Shevchenko. Kyiv: Yuridichna Dumka, 2009. 332 p.

13. Makarukha S. Legal bases of activity of the European Union in the sphere of ensuring space of freedom, safety and justice: monograph / S. Makarukha; Kiev. NATs. UN-t im. T. Shevchenko. Lviv: Astrolabe, 2011. 543.

14. Matviychuk V. counteraction to crime and adaptation of criminal legislation and law of Ukraine to the legislation and law of the European Union: monograph / V. Matviychuk et al.; ed. Acad. UPR. Kyiv: UNIVERSITY "national Academy of management", 2014. $551 \mathrm{~s}$.

15. Mechanisms of law enforcement cooperation in the process of detection and investigation of crimes related to human trafficking: studies / Amer. Assoc. international initiative on the rule of law (ABA / ROLI); podgot.: Marina Elefante, Ludmila Ilkovic. Kiev, 2010. 39 sec.

16. Mikievich M. international legal framework for combating transnational crime within the European Union. Scientific Bulletin of Lviv state University of internal Affairs. 2008. No. 2. P. 1-8.

17. Mironova V. problems of criminal responsibility for violation of laws and customs of war: monograph. Acad. right. Sciences of Ukraine. Kharkiv: Pravo, 2007. $152 \mathrm{p}$.

18. International police encyclopedia: a conceptual framework. Conceptual approach. Theory and practice: In 10 vols. edited by Y. Rymarenko [and others], NAT. Acad. EXT. Affairs of Ukraine, Institute of state and law. V. Koretsky NAS of Ukraine, Acad. right. Sciences of Ukraine, Acad. ruko. Federal police. Republic Of Germany, Member Of The Academy. UPR. M-VA EXT. del Grew. Fader. Kiev: Publishing house "In Jure", 2003.

19. International legal assistance and cooperation in criminal proceedings of Ukraine: ZB. dock.: In 2 h. / way. I. Kogutich; LNU. Of Ivan Franko. 
Department of criminal procedure and criminalistics. Lviv, Triada plus, 2004. Part 1. 2004. 940 p.

20. Sergey Petrashko Fight against corruption: international dimension and national practice: monograph / Sergey Petrashko; In-t legislation of the Verkhovna Rada of Ukraine. Kyiv: Institute of legislation of the Verkhovna Rada of Ukraine, 2014. 231 p.

21. Combating drug-related crime: domestic and international experience of cooperation of law enforcement and judicial authorities. Bekämpfung der Drogenkriminalität. Zusammenarbeit von Polizei und Justiz: proceedings of the Ukr.-he. sciences'.- pract. conf., M. Donetsk, 26-27. 2011 / Verkhovna Rada of Ukraine, com. on issues legislators. sabesp. no. active., Donets. Yuri. Institute of Lugano. state University EXT. cases to them. E.O. Didorenko, G. zaydel Foundation. Donetsk: DUI of LDUS, 2011. $307 \mathrm{p}$.

22. Chornous Julia Theory and practice of forensic support of pre-trial investigation in cases of crimes of international character: monograph. NATs. Acad. EXT. cases'. Kiev: SKIF, 2012. 447 p.

23. Shostko Elena Combating organized crime in European countries: monograph. National law Academy of Ukraine. Yaroslav The Wise. Kharkiv: Pravo, 2009. 44 p.

\section{Information about the author: Klyuev O. M., Doctor of Law, Professor, of the Ministry of Justice of Ukraine} Director of the Kharkiv Scientific Research Institute of Forensic Examinations N.A. Prof. M. S. Bocarius 8-A, 49 Zolochivska str., Kharkiv, 61177, Ukraine 


\section{DOCTRINE OF LEGAL ORDER IN UKRAINIAN AND FOREIGN JURISPRUDENCE: STATUS AND PROSPECTS OF CONVERGENCE LEGAL ORDER AS AN EMPIRICAL STATE OF LEGAL LIFE IN SOCIETY (OR WHATSOEVER)}

\section{Kryzhanovskii A. F.}

\section{I.INTRODUCTION}

I contemplated a lot on the subject of the scientific category "legal order", which was solidly established in domestic jurisprudence, however for some reason was not developed at all by Western legal scholars in some other countries (mostly post-Soviet). The terms "law" and "legal order" are used as synonyms there, despite the fact that they are not semantically identical. For instance, in German the law - die Recht, the legal order Rechtsordnung, although in some dictionaries it is also translated as "law". Approximately the same situation in the English language: law - rights, legislation, legal order - legal system, which are also used synonymously to denote rights and legislation. Legal reality, for many Western authors, is called either law or legal order, without any difference in the meaning of these words. In this regard the book of the French scientist J.-L. Bergel is indicative, as the author intertwines these categories easily and naturally ${ }^{1}$.

In Ukrainian jurisprudence, the content of law and legal order is filled with different meanings. Law in its most general form is a value-normative system, partly generated and maintained by the authorities, and the legal order is the actual state of public relations, the legal sphere of society, which is formed under the influence of law, is the result of the influence of the law on society. Thus, law is a kind of legislative model, and the legal order is the real, actual (and qualitative) state of the legal life of society. Law reflects due, legal order - matter in the legal sphere.

As a result, I seem to understand one of the reasons for these differences. The law (legal values, precepts, principles) has long been an integral part of the conviction in the Western legal tradition, and its component jurisprudence, that it has rigorously embodied in the phenomena of human and social reality - the behavior of people, the relationship between them. Cases of deviation from law (violation of law, abuse of law) receive the

${ }^{1}$ Бержель Жан-Луи. Общая теория права. Пер. с франц. Г.В. Чуршукова. Под общ. ред. В.И. Даниленко. М.: Nota bene, 2000. 576 с. 
appropriate assessment and reaction of state and public institutions and lead to the restoration and approval of the law.

In the domestic tradition, faith in law has never been strong, not only in broad social, but even in professional and legal discourse. The gap between constitutional declarations and reality was obvious, and could not be filled even by the most powerful ideology of public consciousness and the reason is the many years of experience in an autocratic regime, and especially of the totalitarian Soviet regime. This attitude to law by inertia was also preserved in the minds of Ukrainians, especially since the authorities of an already sovereign state, actually, have done little change to it. As a result, even the appearance of "good" laws did not produce quick results in public practice. Therefore, in modern conditions the distance between the legislative provisions can be seen by «unaided eye «and their real implementation in practice. To illustrate this, it is enough to refer to the practice of compliance with traffic rules, or payment of taxes, corruption and many other things. Though this situation did not appear nowadays. Therefore, even prerevolutionary domestic legal scholars saw reasons for distinguishing between the phenomena of law and legal order.

But the question is quite relevant: is the situation with the observance of laws (and law in general) in other (Western) societies today so prosperous, does the "normative model" of society life contained in the law fully coincide with its real picture? Publication of the work of Harold J. Berman's "Law and Revolution: The Formation of the Western Legal Tradition", "tells about the feeling of crisis in the Western tradition of law, sharpened the perception of problems in the legal sphere. It is obvious that the existence of a legal reality in the life of Western societies, different from the declared current law, requires the understanding of this phenomenon. And the differentiation of law and legal order, theoretical and applied research of these phenomena can become a scientific tool in the system of necessary transformations.

\section{Conceptualization of the legal order within the national doctrine of law}

Domestic jurisprudence postulates the legal order as a qualitative state of legal orderliness of social life. It functions in various spheres of society, manifests itself as a domestic (national), integrative and international legal order. The basic category is the national legal order which is associated with the legal and institutional infrastructure of the state-organized society,

\footnotetext{
${ }^{2}$ Garold J. Berman. Law and Revolution I : The Formation of the Western Legal Tradition. Harvard University Press, 1990. Cambridge, Mass, United States. 672 p.
} 
reflects the historical and social features of its legal development. Therefore, comprehension of the nature of the national legal order, the system of its maintenance is an important task of theoretical and applied jurisprudence. Here it is necessary to admit: transformation of legal ordering of public relations in Ukraine in modern conditions is made without seriously proved scientific developments and predictions.

Maintaining and strengthening the legal order in society in modern conditions render necessitates of the functioning of an extensive law enforcement and human rights mechanism with the involvement of state institutions and civil society. This, in turn, requires a thorough doctrinal support, prediction and planning, determining the strategic goal, the main tasks, forms and methods of activity in this area. Mentioned components are the strands of the phenomenon, which got the word-name "doctrine", with the meaning of an integral, socially recognized system of ideas, goals, provisions, methods and means of achieving and solving problems in a certain area (political, economic, legal doctrine, etc. Legal doctrine is also comprehended as an authoritative scientific study of leading legal theorists and practitioners. As an important element of the legal doctrine, the doctrine of legal order is invoked to life by the social needs of legal order, and is significant both for society in general and for individual citizens, their groups and associations. The doctrine of the legal order is able to acquire an official (para-governmental) status if the relevant state or political institutions record the concepts of maintaining and strengthening the legal order in legal or political acts, programs and other documents. In Soviet times, The official doctrine of law and order was determined by the decisions of party or state bodies without the decisive influence of the scientific community.

The formation of the scientific doctrine of the legal order in Ukraine has its own history, the roots of which go back to the achievements of scientists of the XIX century of the Soviet period and modern times.

A prime example of the pre-Soviet period of development of the theory of legal order is the original concept of L. I. Petrazhitsky. The foundation of this concept was the understanding of law by Petrazhitsky as an idea, a phenomenon of the spiritual world, the individual psyche ${ }^{3}$. He considered the legal order as the result of the effect of a set of laws-tendencies of the legal psyche, and defined it as a solid coordinated system of social behavior

${ }^{3}$ Петражицкий Л. И. Теория права и государства в связи с теорией нравственности. Серия “Мир культуры, истории и философии”. СПб. : Лань, 2000. С. 99-100. 
caused by law $^{4}$. Petrazhitsky sees the concept of legal order through the distinction between intuitive and positive law (two kinds of generic concepts), which are rooted in the human psyche and are imperativeattributive emotions of the individual. Unlike holistic intuitive law, positive law is pluralistic. In order to understand the legal order, it is important that intuitive law is perceived by people as eternal and universal. This gives grounds at the naive legal psyche to see a greater weight of the sensations of intuitive law, which gave rise to positive law, which, according to Petrazhitsky, is determined by the purely psychological characteristics of the perception of these two types of law. Intuitive law does not envisage knowledge by individuals of all the moments that characterize positive normative facts. Moreover, Petrazhitsky argues, people can have rather rough ideas about the law (in a broader sense - about normative facts), they generally may not know them. But this does not prevent them from participate in legal relations. The only possible explanation for this phenomenon is that people have an intuitive right. That is why Petrazhitsky repeatedly emphasized that "intuitive law plays a very significant role as a factor in individual behavior, as well as a variety of large-scale social, economic, political and other phenomena"5. Intuitive and positive laws divide legal reality into three areas: the exclusive dominance of intuitive law, the exclusive dominance of positive law, as well as their dual operation. Each of these areas has a separate meaning for the formation of the legal order. The first one is the most important for the reproduction of the informal legal order, the second area manifests itself in the functioning of the state (official) legal order, and the third form of legal order exists at the intersection of the first and second spheres. The study of the third sphere is very relevant from the standpoint of the dynamics of the legal order and the mutual influence and flow of the official and unofficial legal order. Obviously, further in-depth study of the scientific heritage of L.I. Petrazhitsky and extrapolation of its provisions on the problems of the legal order are able to go beyond the horizons in the theoretical and applied planes. However, there is an issue: should positive law adapt to intuitive law, or should informal law gradually "keep up" to the level of positive law requirements? This concern is very important for maintaining a legal order for which a balance between positive and intuitive law is a necessary condition. As it was pointed out by L.I. Petrazhitsky, "the more the degree of

\footnotetext{
${ }^{4}$ Петражицкий Л. И. Теория права и государства в связи с теорией нравственности. Серия “Мир культуры, истории и философии”. СПб. : Лань, 2000. С. 157-158.

${ }^{5}$ Петражицкий Л. И. Теория права и государства в связи с теорией нравственности. Серия “Мир культуры, истории и философии”. СПб. : Лань, 2000. С. 388.
} 
agreement within these limits at the moment is, the better and more correct, ceteris paribus law operates among the people, the more steady its compliance, in particular, the more there is respect and sympathy to the existing positive law, the more contentment because of the existing social system and the stronger this system is; and vice versa"

B. A. Kistyakovsky is a representative of integrative law understanding. He distinguishes law as a social fact and law as a set of legal norms. Their content does not necessarily coincide, and the legal order existing in life is not identical to the rule of law enshrined in legal norms. Hence his call-to study the legal order existing in life as something independent; this will lead to a socio-scientific study of law or to the study of law as a social phenomenon ${ }^{7}$. According to B. A. Kistyakovsky, law is the only regulatory system that disciplines society ${ }^{8}$. Therefore for him, a disciplined society and a society with a developed legal order are identical. Law is a kind of technology of social life, designed to organize it and embody the ideals of due in the social world. Although the scientist never idealized the possibility of law regarding the establishment of a reasonable, free and fair social order. The stability of the legal order and the democratic regime, according to the scientist, is unthinkable without a high level of legal awareness, political and legal culture of the people, their activity in the fight for the rule of law. In this sense, Russian history contains very few positive examples, and the main blame for the lack of awareness of the value of the rule of law by society is assigned to the intelligentsia by Kistyakovsky. To his mind, the intelligentsia never respected the law, never saw value in it; among all cultural values the law never was for them on first place. The ideal of the legal order for B.A. Kistyakovsky has a personalistic character, and is associated with a legal person. The two sides of this ideal are a person disciplined by law and a stable rule of law, and a person endowed with all the rights that he freely enjoys 9 . Kistyakovsky's idea that "the basis of the rule of law is the freedom of the individual and its inviolability" is still relevant today. Kistyakovsky also emphasizes the value of stability, continuity of the rule of law ${ }^{10}$. The appeal to the scientific heritage of

${ }^{6}$ Петражицкий Л. И. Теория права и государства в связи с теорией нравственности. Серия “Мир культуры, истории и философии”. СПб. : Лань, 2000. С. 394.

Кистяковский Б. А. Право как социальное явление. Социологические исследования.1990. № 3. С. 107.

${ }^{8}$ Кистяковский Б. А. В защиту права (Интеллигенция и правосознание). Вехи: Сборник статей о русской интеллигенции. Вехи. Из глубины. М. : Правда, 1991. С. 122.

9 Кистяковский Б. А. В защиту права (Интеллигенция и правосознание). Вехи: Сборник статей о русской интеллигенции. Вехи. Из глубины. М. : Правда, 1991. С. 115.

${ }^{10}$ Кистяковский Б. А. Непрерывность правового порядка. Юридический вестник. 1917. Кн. XVII. C. 10. 
B.A. Kistyakovsky is also useful in the sense that he is the author of almost the only doctrinal definition of legal order in the literature of that time: it is "a system of relations in which all persons of a certain society have the greatest freedom of activity and self-determination"11.

In General, in the pre-Soviet period, there is a general tendency of the development of domestic legal thought in the promotion of an integrative understanding of the rule of law. At the same time, none of the outstanding lawyers of the heyday of legal thought of this time did not set a goal to create a holistic theory of legal order.

Already at the beginning of the Soviet era, the category of "legal order" due to its "ideological unreliability" is generally removed from the official and doctrinal lexicon. The interpretation of public relations as the basis of law, declared by representatives of Marxist jurisprudence, is explained by the need to justify the Soviet court's activity in accordance with the"revolutionary consciousness and legal consciousness". Legal order is a category that does not fit into the Bolshevik concept. After controversial discussions between Pashukanis and Knocking and Vyshinsky's massacre of these "traitors, enemies of the people, defenders of Trotskyist and Bukharin ideas" the category of order disappeared from the definitions of jurisprudence, and the rule of law - as a legal category "lost its relevance". The category by means of which the qualitative state of "legal" life is determined, for many years has become legality (revolutionary, proletarian, socialist, etc.). At the same time, during the formation of socialist jurisprudence in the first years of Soviet power, the identification of law and order became widespread. The typical one is the definition of law A.L. Malitsky. "Law," he wrote, «is the order of social relations established by the ruling class for the sake of its class interests, which is protected by the organized power of that class. Law, as order, or as the rule of law, manifests itself in certain rules of conduct, is protected by the organized force of the ruling class in the rules of law." Considering the state to be the Creator of law, which guarantees its citizens with rights, Malitsky argues that the "bourgeois" principle is "everything that is not prohibited by law and is considered permissible" and it should be replaced by the principle "only what is allowed by law is possible" $"$.

Legal order as a concept widely used by scientists and practitioners again received registration in the Soviet legal literature only in the mid-60s, to

11 Кистяковский Б. А. В защиту права (Интеллигенция и правосознание). Вехи: Сборник статей о русской интеллигенции. Вехи. Из глубины. М. : Правда, 1991. С. 119.

12 Кистяковский Б. А. В защиту права (Интеллигенция и правосознание). Вехи: Сборник статей о русской интеллигенции. Вехи. Из глубины. М. : Правда, 1991. С. 49. 
some extent, as a reflection of the normative theory of G. Kelsen, but in the form of ideologically oriented, opportunistic constructs. Kelsen's characteristic statism of understanding law and order (law - compulsory normative order of human behavior) paradoxically proved acceptable to the Soviet official legal doctrine, and until a certain time existed in all spheres of domestic jurisprudence. The understanding of law as a system of obligatory norms and prescriptions of state power somehow forms the statist model of law and order, according to which it is interpreted as the order of social relations regulated by the norms of law, established in compliance with the requirements of legality. If, however, the rule of law is understood primarily as a regime that characterizes the relationship between the state apparatus and the citizen, it is obvious that in this model of law and order, the role of the main force that establishes and ensures the rule of law is assigned exclusively to the state. For the one lastr, the citizen is only an object of power activity. In the framework of the statist paradigm the semantic field of the category of the rule of law traditionally considered in connection with the legality, mainly as a derivative of law, and therefore, in fact, is in the shadow of the law. Often, even in thorough scientific works, the phrasestamp "law and order" reflects just such a non-independent, secondary doctrinal, and, therefore, the practical status of law and order.

The perception of law as a consequence, the result of law not only distorts the understanding of the social aspects and values of legal ordering of social life, inappropriately exaggerates the significance of law in the ratio of the categories "law and order", but also spreading statism on the level of legal phenomena, vital for society as a whole, underestimates the scale of the importance of the rule of law as a social and personality legal values. It impoverishes the understanding of legal reality as beyond its perception remain a social base, the characteristics of law as a socio-legal phenomenon, the existence of which is correlated by the influence of the entire social system of control of public relations and ensuring the integrity of the society.

If to understand Statism in terms of law and order it leads to the fact that the subject of the formation of law and order (the state) is somehow opposed to its carriers-society and the citizen. This has significant practical implications. That is why the assessment of the rule of law is carried out on the basis of its comparison with offenses and crime, that is, only one of the many manifestations of legal deformation. A very different picture is formed if the rule of law is opposed to the disorder and destruction of law: this opens the possibility of penetrating into the underlying formation of conditions that form and destroy the rule of law. And the task of ensuring law and order becomes possible to formulate not in a negative sense (fighting crime, stopping offenses, etc.), but as a program of positive, 
socially oriented actions and means that have a reliable legal basis. Inherited from the Soviet era, "linear" ideas about the rule of law as a result of socialist legality, that is, the consequence of "strict and rigorous execution by state bodies, officials, public organizations and citizens of laws and regulations" in modern conditions of de-ideologize of legal sphere has largely lost its public appeal and effectiveness. However, with the inertia inherent in the doctrinal sphere, these ideas retain their existence in theoretical, applied, and especially in practical jurisprudence, or acquire new outlines. "The rule of law, - Yu.N. Oborotov emphasizes, - stands as the semantic purpose of law, which is achieved by ensuring the stability of human existence. However, often in the system of legal values the defining place is given to freedom and justice, while the rule of law is considered as the "lowest in rank" in the hierarchy of values of law and is even characterized as an additional value"13. To a large extent, the doctrinal and applied images of law and order in Ukrainian jurisprudence now retain postSoviet characteristics, against which the beginnings of its new vision grow.

Therefore, the way out of this situation is not only in overcoming the statist paradigm of understanding and formation of the rule of law, but also in moving to another level of its perception, first of all, in comparing the rule of law with the legal categories of meta- and mega-levels (law, legal reality, legal life, legal culture, etc.). This level sets the change of methodological vectors of development of law and order, appeal to those developments of modern jurisprudence, which open new horizons of its comprehending. At the same time, it significantly expands the perception of the whole picture of legal life.

The state of legal spheres of modern society requires a rethinking of the whole complex of theoretical applied problems concerning the nature of law, the role and importance of civil society and the state in its provision, identifying the whole system of factors and conditions that affect the condition of the rule of law and tendencies of its development. Such factors include worldwide - globalization, environmental and energy problems, terrorism and organized crime, the "information revolution", the transformation of public consciousness, called postmodern, as well as internal - the level of political stability, economic and foreign policy, the effectiveness and social orientation of public administration, the quality of functioning of law-protecting institutions of the state and civil society.

\footnotetext{
${ }^{13}$ Оборотов Ю. Н. Аксионормативные начала правопорядка. Сучасний правопорядок: національний, інтегративний та міжнародний виміри: Тези Міжнародної науковопрактичної конференції. О.: Фенікс, 2008. С. 6.
} 
The range of problems that are waiting for their resolution by legal theorists, representatives of industry and applied jurisprudence, covers the concept and structure of the rule of law, the basic (key) principles on the basis of which its ideal model should be built. It is necessary to develop criteria allowing giving an objective assessment of the real state of the legal order in different spheres of public life, means and methods of its strengthening in the conditions of ongoing transformations, complication of the socio-political and economic situation, etc. All this brings the problem of law and order in the plane of the need for its systematic awareness, rethinking on the basis of modern, adequate to the nature of modern law and order, methodological approaches.

The theoretical component of modern systemic vision of the rule of law requires understanding the contexts available in the law basic concepts of law to disclose the correlation of law and right, law and order and public order, rule of law, legitimate and law-violating behavior, legal relationships, etc. Extrapolation of the problems of law and order or some type of legal thinking in a certain way highlights the role of the state and civil society in the formation of the rule of law, principles, forms and methods of its provision.

It should be admitted that in the modern Ukrainian jurisprudence, new views on the rule of law are approved, which create a certain scientific basis for the development of the modern domestic doctrine of the legal order. The characterizing the doctrinal perception of the legal order defining moment is the presence of solidarity of the scientific community in the understanding of the high importance of the legal order in the system of legal categories, which is rightly noted by N. N. Onishchenko, along with others (public order, legality, social security, etc.) is key in legal science and law enforcement practice ${ }^{14}$. This gives grounds to consider the legal order in accordance with the approach declared by A. M. Vasilyev ${ }^{15}$, in the most extended content-semantic range of categories of the theory of law. It is very symbolic that N.I. Kozyubra focused his vision of the rule of law on its comparison with the rule of $\operatorname{law}^{16}$ : this methodological section opens a

${ }^{14}$ Оніщенко Н. М. Категорія правопорядок: сутнісні виміри, підходи та розуміння. Сучасний правопорядок: національний, інтегративний та міжнародний виміри: Тези Міжнародної науково-практичної конференції. О.: Фенікс, 2008. С. 63.

15 Васильев А. М. Правовые категории. Методологические аспекты разработки системы категорий теории права. М., 1976.

16 Козюбра М. I. Додержання вимог принципу верховенства права як умова забезпечення правопорядку. Сучасний правопорядок: наиіональний, інтегративний та міжнародний виміри: Тези Міжнародної науково-практичної конферениії. О.: Фенікс, 2008. C. 58. 
powerful synergistic potential of interaction between these basic legal phenomena, the possibility of mastering other legal phenomena. Undoubtedly, the rule of law, as a fundamental legal value, implicitly contains a system of values of the legal order. Among them Yu.N. Oborotov refers to as the principles of humanism (humanity), legitimacy (recognition), legality (formality), justice (conformity of action and retribution), procedural (procedure), tolerance( tolerance), hierarchy (subordination), situativeness (discretion) $)^{17}$. N.I. Kozyubra speaks about the principles of decisive importance of natural, inalienable and inalienable human rights and freedoms in relations with the authorities, the separation of powers, the supremacy of the Constitution, the principles of certainty, proportionality, legal security and protection of trust, as well as the independence of the court and judges ${ }^{18}$. The rule of law means legality, based on the recognition of unconditional acceptance of the Supreme value of human, his protection from the arbitrariness of power institutions and their officials. Therefore, "... the requirement of legality in accordance with the rule of law applies only to the activities of public authorities and their officials, and not to citizens. Quite often this requirement is referred to as the legitimacy of governance. According to it, no act of government can substitute its regulation for the law, and any action or authority of the governing body must have its basis in the law, that is, comply with the principle "what is not expressly permitted by law, is prohibited"19. Following this approach, it is necessary to distinguish the achieved legal order in the activities of state institutions as one that is formed on the basis of legality. This legal order, on the one hand, is a relatively independent sphere of legal life of society, and the other - an important factor of legal order in other areas (economic, industrial, social, political, ideological, etc.). From this arises the possibility of analyzing the role of state institutions and civil society institutions in ensuring the legal order in society, and the reflection of these provisions in the doctrine of the legal order.

Methodologically important for the development of the modern doctrine of the legal order is the need approach to law (scientific school of

${ }^{17}$ Оборотов Ю. Н. Аксионормативные начала правопорядка. Сучасний правопорядок: національний, інтегративний та міжнародний виміри: Тези Міжнародної науковопрактичної конференції. О.: Фенікс, 2008. С. 6.

${ }^{18}$ Козюбра М. І. Принципи верховенства права і правової держави : єдність основних вимог. Наукові записки Національного університету "Києво-Могилянська академія". Юридичні науки. 2007. Т. 64. С. 3-7.

${ }^{19}$ Козюбра М. І. Принципи верховенства права і правової держави : єдність основних вимог. Наукові записки Національного університету “Києво-Могилянська академія". Юридичні науки. 2007. Т. 64. С. 59. 
P.M. Rabinovich). This approach opens the possibility of mastering the legal order as a value inherent not only in the social being of man, but also as a human - biological being. The needs of a safe existence, a sense of security from external dangers have been and remain a powerful mover of human social activity, the formation of an extensive "infrastructure" of the ordering and safety of their lives. As P.M. Rabinovich observes, it is the "need" reasons are often more effective than other circumstances ${ }^{20}$. Therefore, the potential of the need-based approach based on anthropocentric principles should also be reflected in the doctrine of the modern legal order.

A vivid example of a doctrinal breakthrough in the search for the theoretical basis of the modern legal order is the idea of A.N. Kostenko and his followers. Naturalistic jurisprudence, based on the theory of social naturalism, offers the position that "the rule of law is a state that is formed in the implementation of existing legislation, in which the laws of "natural law" are embodied"21. Very valuable for the understanding of the modern legal order should be recognized not just the proclamation of the unity of legal culture and positive law, but also the emphasis that the legal culture of citizens is understood as a measure of coordination of their will and consciousness with the laws of natural law. Therefore, «in the activities ensuring law and order, - A.N. Kostenko says, - it is necessary to be guided by the rule: culture is the mother of order" ${ }^{\prime 2}$.

The legal order, without exaggeration - is an important dimension, an independent and objectively necessary hypostasis of the existence of law. Without its embodiment in law-meaningful (first of all, lawful) behavior, legal relations, which according to the laws of "Brownian motion" are formed into a system of orderly legal life, law would remain a great idea, a system of perfect texts, principles, norms and regulations. The rule of law O.F. Skakun indicates, - is the superlative, (end result) of the right and necessary condition for the functioning of a social system ${ }^{23}$. The state and quality of the legal order give real ideas about the state of the "legal health" of society, the legal security of citizens (and sometimes of the whole society), as well as about the legal culture of society and its components.

\footnotetext{
${ }^{20}$ Рабінович П. Сутність право розуміння. Право Украӥни. 2008. № 9. С. 6.

${ }^{21}$ Костенко А. Н. Теория “натуралистической” юриспруденции - основа нового правопорядка. Сучасний правопорядок: національний, інтегративний та міжнародний виміри: Тези Міжнародної науково-практичної конферениї. О.: Фенікс. 2008. С. 14.

${ }^{22}$ Костенко А. Н. Теория “натуралистической” юриспруденции - основа нового правопорядка. Сучасний правопорядок: начіональний, інтегративний та міжнародний виміри: Тези Міжнародної науково-практичної конферениї. О.: Фенікс. 2008. С. 14.

${ }^{23}$ Скакун О. Ф. Теорія держави і права (Енциклопедичний курс) : підручник. Х. : Еспада, 2006. С.730.
} 
Therefore, the legal order is perceived as a favorable state (environment) of the legal sphere, which the life of individuals, public entities and society is in. Here the remark of O.F. Skakun is very fair: the legal order as dynamic system incorporates all ordering bases of legal character ${ }^{24}$. It should be added that the legal order is the result of a whole complex of social and legal factors and conditions that, acting in conjunction or in "competition", create a certain configuration of the legal order, provide a certain state of it, and therefore its real characteristics depend not only on law and other legal means, but also on a wider range of them-social, political, economic, etc. Therefore, the doctrine of the legal order should be based on the positions developed by science, in accordance with which the doctrinal image can be formed and the modern legal order can be proclaimed as a concept that can be effective in the practice of legal ordering of modern society.

The assertion of the idea of law as a measure of freedom, justice and formal equality in the public consciousness has a powerful potential in creating the doctrine of the modern legal order. No less important is the understanding of the carriers of professional and competent consciousness of pluralism sources of modern law and legal order, the importance primarily of those that derive their origin from natural law, recognized by the civilized world standards of human rights and freedoms. Normative sources of legal order (principles of law, normative legal acts, precedents, legal values and traditions, doctrine) are equal in the legal regulation of public relations, and the law is recognized as a source of legal order on condition that it is a rights law.

The modern legal order is intended to be a legitimate order in the legal sphere, that is, the actual (actually existing) state of order of the legal life of society, which is maintained by the dominant part of society, primarily by civil society, for which it is necessary and most valuable. The legitimacy of the legal order is determined by its compliance with the interests and needs of civil society, which is in solidarity with the existing legal order, and by its will and efforts contributes to its establishment and sustainable functioning. The legitimacy of the legal order informs it not of the state, but of the social nature. Therefore, the modern legal order is a civil legal order, because its image, standards and support come from civil society, are transmitted to the state, and are carried out under the control of civil society. Such a legal order is formed, first of all, by the daily self-organization of civil society and is supported by an extensive system of its institutions, and, therefore, not only does not limit the freedom of the individual, but also contributes to the disclosure of its creative potential.

\footnotetext{
${ }^{24}$ Скакун О. Ф. Теорія держави і права (Енциклопедичний курс) : підручник. Х. : Еспада, 2006. С. 669.
} 
The nowadays legal order is conceived as a legal order in the legal sphere, which, thanks to social consciousness and civil society institutions (primarily independent and unbiased media) is reproduced and developed as a state of explicit, transparent legal existence. The adequacy of the perception of the legal order by society is not deformed by ideological clichés and official myths. Latent legal processes, illegal quasi-legal practices and other deviations from the modern legal order receive reliable, first of all, doctrinal and professional legal expert assessment and are subject to rational influences of the relevant institutions of the state and civil society.

The modern legal order also needs such quality as its economic expediency, the ability to be a kind of "legal capital" in the economic sphere of public life, a legal environment that promotes the activation of entrepreneurial activity, attracting investment. Such characteristic of the modern legal order as its maintenance within reasonable (optimum) material and financial costs for society, that is unencumbered for the state budget is also important.

The modern legal order is a morally justified and religiously verified order in the legal sphere. This trait of it characterizes the fact that the moral and religious foundations provide its reliability and stability, as well as additional legitimation.

The modern legal order should be provided with a necessary, sufficient (but not excessive), highly organized, operating on a legal and professional basis, effective system of specialized law enforcement institutions. Rational, consistently scientific solution of this problem in the framework of the doctrine of legal order should be based on a clear definition of the role and place of state institutions in this area so that these activities, on the one hand, was extra to self-organization society, and with another - will likely be necessary and effective. And most importantly, to the state power with its institutions without any exception to act in the framework of legal legitimacy, and to support with its efforts the state of legal order in society.

\section{CONCLUSIONS}

The legal order in the today's era appears as a polystructural, multi-level phenomenon, the legal nature of which reflects the dominant tendencies to deepen the diversity of legal existence. Therefore, the doctrine of the contemporary legal order must take into account the diversity of legal orders in modern society, to cover all-both large-scale and the smallest elements of the legal ordering of social life. The multiplicity of legal orders determines the need to choose effective means of ensuring the legal order in different spheres of society. 
The legal order is a "companion", a factor and a condition of civilized life of people, and by virtue of the social and spatial existence of the person himself arises and is established where his social activity takes place. The "primary carrier" of the legal order is the individual. Each subject of law by his daily behavior "creates" the legal order, affects the "General legal picture" in public places, at work, in the village, city, etc. It is on the basis that the subject of the creation of order is first an individual and then a variety of associations of people - legal entities, bodies, organizations, etc. - jurists distinguish between individual and collective law and order ${ }^{25}$. These classes of legal orders in theoretical discourse can be methodologically significant categories for understanding the "atomicity" and complex structuring of the legal order precisely from the point of view of the role of man in its formation. In the practical sense, this means the need to shift the emphasis in the formation of the legal order in the plane of maximum involvement of the personal legal potential of each individual (legal person).

The legal order is always connected with a certain human community and the sovereign power legalized in it, which exist in a certain territorial space within the recognized state borders. The legal order is territorially formed as identical to the territorial configuration of society and the state-in a certain way the existing areas of human activity. Since each state within its borders seeks to provide its own means and methods of a certain legal order, (and this differs from the legal structure of other countries), so it is this order, which arises and operates within a separate sovereign state, and can be defined as a category of Genesis for the development of legal doctrine. This legal order can be conditionally called the national legal order.

National legal order, as a basic category in the characteristics of the plurality of legal order, is the basis of many institutional entities that are produced by society and its power institutions to ensure the legal order in the life of society. Therefore, as part of the national law and order, there are grounds to see such elements as localized (law and order that is in established institutionalized human collectives), local (village, city, district) and regional (region, province, district, etc.) legal orders. These grounds are connected with the fact that people mediate their life activity in the territorial organizations of villages, cities, regions, on the "territorial-human" expanses of which the legal order of life is formed. Actually, each person "feels", i.e., perceives the rule of law at the level

\footnotetext{
${ }^{25}$ Общая теория права : пер. с франц. Под общ. ред. В. И. Даниленко. М. : NOTA BENE, 2000. C. 332.
} 
of events of everyday life, the immediate environment, as a system of factors that have direct contact with his needs and interests, security, etc. Labor, educational or social activity of a person is mediated in the respective collectives, where a certain state (atmosphere, environment) of the legal order is also formed. This order is characterized by corporatism, it is formed within communities that perform certain social functions and are regulated by a special system of legal regulations. Such laws are called specialized in contrast to the General, devoid of such specificity. The separation of the components of the national legal order is not only doctrinal, but also practical because the national legal order, which is perceived as a whole, is actually quite vague. It consists of different, unequal in quantitative and qualitative characteristics of law and order, which differ significantly from each other. It is no secret that the state and level of legal order in different cities and regions of Ukraine have significant differences. Therefore, the doctrine of the modern legal order should take into account the nature of these differences, and provide for the use of effective means to overcome negative imbalances.

The current state of the doctrine of the legal order in Ukraine reflects both the General situation in the legal sphere of public life, and in doctrinal theoretical and applied jurisprudence, in particular. The need for large-scale transformations in the field of establishing the rule of law in Ukraine, reforming the state apparatus, combating corruption, forms a public demand for modern innovative solutions to these problems as components of strengthening the modern legal order. The phenomenon of legal order here appears in two hypostases - as a doctrinal context, a theoretical model of legal ordering of social life, and as a result of the entire process of legal development of society.

\section{SUMMARY}

Discussion by the scientific community of the fundamental problems of legal development of Ukrainian society, in our opinion, will create the necessary prerequisites for the development of a modern doctrine of the legal order and the successful solution of practical problems in the field of its maintenance. Attracting the attention of foreign scientists to the problems of distinguishing law and legal order will allow to hold a discussion on a set of issues leading to the convergence of legal doctrines.

\section{REFERENCES}

1. Бержель Жан-Луи. Общая теория права / пер. с франц. Г. В. Чуршукова : под общ. ред. В. И. Даниленко. М.: Nota bene, 2000. $576 \mathrm{c}$. 
2. Васильев А. М. Правовые категории. Методологические аспекты разработки системы категорий теории права. М., 1976. 264 с.

3. Garold J. Berman. Law and Revolution I : The Formation of the Western Legal Tradition. Harvard University Press, 1990. Cambridge, Mass, United States. 672 p.

4. Кистяковский Б. А. Право как социальное явление. Соичилогические исследования. 1990. № 3. С. 99-109.

5. Кистяковский Б. А. В защиту права (Интеллигенция и правосознание). Вехи: Сборник статей о русской интеллигенции. Вехи. Из глубины. М. : Правда, 1991. С. 122-149.

6. Кистяковский Б. А. Социальные науки и право. М.: Издание М. и С. Сабашниковых, 1916. 718 с.

7. Кистяковский Б.А. Непрерывность правового порядка. Юридический вестник. 1917. Кн. XVII. С. 7-10.

8. Козюбра М.I. Принципи верховенства права і правової держави : єдність основних вимог. Наукові записки Національного університету “Києво-Могилянська академія”. Юридичні науки. 2007. Том 64. С. 3-7.

9. Козюбра М.I. Додержання вимог принципу верховенства права як умова забезпечення правопорядку. Сучасний правопорядок: національний, інтегративний та міжнародний виміри: Тези Міжнародної науково-практичної конференції. О.: Фенікс, 2008. C. 58-62.

10. Костенко А.Н. Теория “натуралистической” юриспруденции основа нового правопорядка. Сучасний правопорядок: наиіональний, інтегративний та міжнародний виміри: Тези Міжнародної науковопрактичної конферениї̈. О.: Фенікс, 2008. С. 12-15.

11. Малицкий А. Советская конституция. Харьков, 1924. 188 с.

12. Оборотов Ю. Н. Аксионормативные начала правопорядка. Сучасний правопорядок: національний, інтегративний та міжнародний виміри: Тези Міжнародної науково-практичної конференції. О.: Фенікс, 2008. С. 5-7.

13. Оніщенко Н.М. Категорія правопорядок: сутнісні виміри, підходи та розуміння. Сучасний правопорядок: наиіональний, інтегративний та міжнародний виміри: Тези Міжнародної науковопрактичної конференщії. О.: Фенікс, 2008. С. 63-65.

14. Петражицкий Л. И. Теория права и государства в связи с теорией нравственности. Серия “Мир культуры, истории и философии”. СПб. : Лань, 2000. 608 с.

15. Рабінович П. Сутність праворозуміння. Право України. 2007. № 9. C. 3-7. 
16. Селіванов А.О. Проблемні аспекти законотворчого процесу та їх відображення в рішеннях Конституційного Суду України. Право України. 2004. № 9. С. 34-36.

17. Скакун О. Ф. Теорія держави i права (енциклопедичний курс) : підручник. Х. : Еспада, 2006. 840 с.

Information about the author: Kryzhanovskii A. F.,

Great Doctor of Law, Professor, Head of the Department of State and Legal Disciplines, International Humanitarian University 33, Fontanska Road str., Odessa, 65009, Ukraine 


\section{METHODOLOGICAL BASIS OF THE RESEARCH OF LEGAL ALGORITHMS}

Manko D. G.

\section{INTRODUCTION}

Disclosure of the essence and legal nature of legal algorithms, and technologies of legal activity is connected with the necessity of establishing clear methodological tools, defining terms, concepts and categories of application of which will ensure the completeness, and comprehensiveness of their scientific comprehension.

Correct methodological planning of the principals of the research is the key to a consistent study of the problem identified, the achievement of the goal and the fullest disclosure of the tasks set.

P.M. Rabinovich, defines the methodology of legal science (in the narrow sense) as "a system of approaches, methods and approach of scientific research, a theoretical basis for their use in the study of state and legal phenomena" 1 .

In her turn, N. Onishchenko, analyzing the methodology of the theory of state and law, noted that the latter, being a systematic set of special cognitive methods, means, methods of studying the state and law, laws of their origin and development, is based on certain, inherent principles of research state and legal reality ${ }^{2}$.

S.S. Slivka indicates, that "under methodology should be understood to have acquired settings, formed views, a certain point of view and, in general, and a worldview that can be implemented using certain methods, approaches and means"3.

Particular attention should be paid to the definition methodology of state theory and law, formulated by O.F. Skakun: "it is a system of general approaches, principles, methods, and means of knowing the law and the state, realized on the basis of knowledge about the laws of their application,

${ }^{1}$ Рабінович П. М. Методологія юридичної науки // Юридична енциклопедія. К., 2001. T. 3. C. 618.

2 Теорія держави і права. Академічний курс: Підручник / За ред. О. В. Зайчука, Н. М. Оніщенко. К.: Юрінком Інтер, 2006. С. 38.

${ }^{3}$ Сливка С. С. Філософія права: методологічне осмислення / С. С. Сливка // Право України, 2011. N8. С. 62. 
through a set of legal concepts and categories, as well as the doctrine of theoretical foundations of their cognitive use ${ }^{4}$.

According to the scientific position of M.S. Kelman, methodology "is the doctrine of the structure, logical organization, methods, means and forms of activity of the researcher in the process of knowledge of the phenomena studied by him" .

Revealing the essence of the methodology of law, D.A. Kerimov pointed out, that "methodology, as a set of approaches, principles, methods ensuring the correct application of concepts and categories in cognition, should reflect the specifics of the process of cognition, orient the subject of cognition on how it is necessary to lead: what and in what sequence of procedures should be performed, which sides of the investigated sources of law should be studied, and from which one can abstract, how the theoretical and conceptual apparatus should be used in cognition, thus determining the most expeditious way of achieving objective truth",

The jurisprudence methodology can be consider from a narrow and wide angle viewpoint. When applying a broad approach, we can establish that methodology is not only a system of principles, approaches and methods, but also a system of knowledge about their purpose, and features of application. In turn, in a narrow sense, the methodology reflects the set of principles, approaches and methods used in the process of knowledge of state and legal phenomena.

In this research, the concept of methodology is considered in a narrow sense, and encompasses a system of principles, approaches, concepts, and methods used to define and substantiate the concept and legal nature of legal algorithms and technologies of legal practice.

\section{Postmodern principles of the research of legal algorithms}

An important step in determining the methodological foundations of the study, is the need to justify the type of legal thinking, that is in line with the spirit of the study, and is seen as the most successful for the disclosure of its subject.

Consideration the current tendencies of legal science, to seek an understanding of law, in our view, it is the integrative type of legal thinking,

\footnotetext{
${ }^{4}$ Скакун О. Ф. Теорія держави і права: Підручник / Пер. з рос. Харків: Консум, 2001. C. 8 .

5 Кельман М. С. Методологія сучасного правознавства: становлення та основні напрямки розвитку: дис.. ... д-ра юрид. наук: спец. 12.00.01. “Теорія та історія держави і права; історія політичних і правових учень” М. С. Кельман; МВС України, Львівський державний університет внутрішніх справ. Л., 2013. С. 44.

${ }^{6}$ Керимов Д. А. Методология права: Предмет. Функции. Проблемы философии права / Д. А. Керимов ; ИГиП РАН. [2-е изд.] М. : Аванта+, 2001. С. 70.
} 
that is such a "proper" way of research. Integrative understanding should be the necessary potential, for not only the disclosure of environmental rights, but also the establishment of action between "living law", "right in life", "right in texts". This type allows you to synthesize a legal idea and change rights, form rights, legal communication and relationships.

Also,It should be noted, that in the research, in the process of characterization of the type of legal understanding, the term "integrative legal thinking" is used and preferred, rather than the term "integrated legal understanding".

The indicated position is justified, on the based on etymology, a concept integration and integrity, where the first means a certain integration of the parts, as a whole through the synthesis of the starting provisions, and analysis of differences, and second, it reflects the inseparable connection of the parts, that form the whole.

In addition, the author's understanding and knowledge of the subject, the analysis of the initial provisions of the study were carried out, in accordance with the spirit of postmodern methodology of legal science.

It should be agreed with E.M. Oborotov, and M.I. Kozyubra, that "the attempt to introduce the principles of postmodern philosophy to legal studies with the understanding of pluralisticism, as the postulation of the multiplicity of worlds, the ontological diversity of the" beginnings "of the world have come to light and in the understanding of other legal basis of components juristic science, in particular, on the issue of legal understanding ${ }^{7}$. "From this situation, the type of legal thinking, based on the need to take into account the relativity of knowledge to the extra-scientific values, and orientations of the subject, begins to be defined, as determined by the outlook of the subject of cognition the image of law" .

In mentioned aspect, it is necessary to take into account E.M. Oborotov scientific position, related to the fact that, "the presence of a wide range of views on law (types of legal understanding), is recognized,as a direct and necessary consequence of the use of non-classical methodology, and methodology of postmodernism, which is characterized by the recognition of the" mosaic "of the existing legal world ... It is necessary, to develop an integrative understanding, within which for the association certain aspects of being right are subject to unification, thereby providing a synthesis of those constituents of law, that are denoted by different, competing scientific

\footnotetext{
${ }^{7}$ Оборотов Ю. Н. Філософія права і методологія юриспруденції / Ю.Н. Оборотов // Проблеми філософії права. 2003. Том 1. С. 41.

${ }^{8}$ Козюбра М. Праворозуміння : поняття, типи та рівень / М. Козюбра // Право Украйни : Юрид. журн. 2010. № 4. С. 14.
} 
theories. As a result of such integration, law should emerge as a multifaceted structure, and legal understanding, as a reflection of the axiomatic characteristics of legal reality"'.

In turn, P.M. Rabinovich stresses, that "the creation of an integrative theory of law must occur around a certain a single conceptual and meaningful nucleus, a certain outlook and philosophical core, should to be found, and the a priori postulation of the concept of law is thus declared inadmissible" 10 .

In some ways developing the approaches, proposed by E.M. Oborotov and P.M Rabinovich to integrative legal thinking, we can assume, that such an "conceptual and meaningful core" of the "mosaic of the existing legal world" is the axiological component of law. It is thanks to the unique values of law, and the identity of basic legal values, that we can define its social purpose, get closer to understanding its essence and nature.

It should be noted, that the idea of integrative jurisprudence,emerged around the 60s of the twentieth century in the United States. Jerome Hall and Harold Berman should be considered scholars, who substantiated the starting points, and the social value of this type of understanding the law. The main idea of integrative jurisprudence, they identified the possibility-necessity, in order to approximate the understanding of the nature of law, integration within the framework of a single legal theory, the initial postulates of value, normative and social existence of law. In particular, Jerome Hall noted, that law "is a type of social action, a process in which principles, values, and facts grow and become actualized" $"$.

N.M. Krestovskaya, analyzing the modern varieties of integrative (integral) legal understanding of the representatives of the post-Soviet space, notes that today it becomes possible to isolate: the realistic positivism of R.A. Romashov; communicative theory of law A.V. Polyakov; the dialogical theory of law I.L. Chestnova; the libertarian theory of V.S. Nersesianets, and the institutional theory of V.O. Chetvernin; the natural-positive theory of law V.M. Shafirov; social and naturalistic jurisprudence O.M. Kostenko; the demand theory of P.M. Rabinovich; value-normative theory of law E.M. Oborotov ${ }^{12}$.

9 Оборотов Ю. Праворозуміння як аксіоматичне начало (постулат) права / Ю. Оборотов // Право України 2010. № 4. С. 49-55.

10 Рабінович П. Трансформація методології вітчизняного праводержавознавства: досягнення і проблеми / П. Рабінович // Юридична Украӥна. 2003. № 1. С. 11.

${ }^{11}$ Hall J. Integrative Jurisprudence. N.Y,. 1961.

${ }^{12}$ Крестовська Н. М., Матвєєва Л. Г. Теорія держави і права. Підручник. Практикум. Тести: підручник / Н. М. Крестовська, Л. Г. Матвєєва. К.: Юрінком Інтер, 2015. C. $235-238$. 
Taking into account the opinion of A.M. Kovtonuk, that "the integrative type of legal thinking... called with the help of a new one to see nonclassical approach to scientific rationality, as a holistic intersubject phenomenon and not eclectic to combine, but synthesize a significant moments, developed by competing scientific theories" 13 , we can insist. that the distinctive types of integrative thinking do not contradict, but rather complement the universal perception and understanding of law, and therefore, they are perform necessary components in the process of learning about legal algorithms, and technologies of legal activity, within the framework basically, at least in the context of research, of an integrative type of legal thinking.

Given the insignificant difference in understanding between Western and post-Soviet scientific studies, regarding the starting points of the varieties of integrative legal comprehend, the latter served as the basis for forming a copyright understanding of the law and, accordingly, for constructing a further path of scientific development.

From the totality of these varieties of integrative legal thinking, the most important in the context of the study of legal algorithms and technologies of legal activity are: realistic R.A. Romashov positivism; communicative theory of law A.V. Polyakov; liberal theory of V.S. Nersesyanets; valuenormative theory of law E.M. Oborotov.

Analyzing E.M. Oborotov's substantiated value normative legal understanding, it should be noted that the right should be perceived, as a system in which, both norms and values function.

Value-normative understanding offers the right to understand "a historically formed, morally grounded and religiously validated, legalized value-normative system, which is designed for universal recognition (legitimating) and appropriate behavior of people, organizations, social communities, which uses procedures, formalized decisions and state coercion, to prevent and resolve conflicts, preserve social integrity" 14 .

The value-normative approach, first of all, allows to reveal axiological components of legal algorithms and technologies, to establish morally grounded, and religiously grounded principles of formation of procedures of behavior of people and other subjects of law.

As E.M. Oborotov emphasizes, "the central ideas of value-normative orthodoxy are, first, the conflicting purpose of law and, second, the need to

13 Ковтонюк А. М. Основні концепції права в інтегративній юриспруденції / А. М. Ковтонюк // Університетські наукові записки. 2007. № 4. С. 32.

14 Общетеоретическая юриспруденция. Учебный курс: учеб./ под ред. Ю. Н. Оборотова. Одесса : Феникс, 2011. С. 56-57. 
preserve existing social integrity. The semantic characteristics of law and the profession of lawyer are always associated with the possibility preventing conflict situations, and in their occurrence - the optimal solution. Just as the purpose of law from its inception in ancient society to the present day is to ensure the integrity of human existence from kind and tribe in antiquity, to family and state in modern life" $"$.

But, in this specified aspect, it is quite correct to note K.V. Gorobets, who states that "the concept of law developed within the framework of value, and normative understanding is relevant only, when law is understood,as a value and normative system of the national level, that is dependent on tradition., culture, religion, morality, etc. n. specific social community. It is difficult to argue, that modern international law, transnational law, integrative and global law, also identified as a systems of value-normative type, and therefore the definition given does not apply"16.

It should be noted, that value-based legal norms confirm the appropriateness of legal pluralism, justifying the need for coexistence, within the framework of the law of values and socially significant legal prescriptions.

Analyzing the concept of realistic positivism, we can distinguish the following components of the understanding of law: the universality and effectiveness of legal rules; the main purpose of legal influence is to ensure social stability, security and development; functional structure - legal norms whose social relations are governed by the rules of law, guarantees of implementation and results obtained through legal influence. Law, within the framework of this concept, is understood as "a set of formal sources"17.

The provisions, that have been substantiated within the concept of realistic positivism, make it possible to disclose the nature of the result of legal influence and, consequently, of the tasks to be formulated in the legal algorithm and of the rules, requirements and principles to be used in legal technologies.

From the point of view of communicative theory, law is a communicative order of relations based on socially recognized and binding norms, whose members have mutually agreed powers and responsibilities.

15 Общетеоретическая юриспруденция. Учебный курс : учеб./ под ред. Ю. Н. Оборотова. Одесса : Феникс, 2011. С. 57-58.

${ }^{16}$ Горобець К. В. Аксиосфера права: философский и юридический дискурс : моногр. $/$ К.В. Горобец. Одесса : Фенікс, 2013. С. 49.

${ }^{17}$ Ромашов Р. А. Реалистический позитивизм как интегративный тип современного правопонимания / Р. А. Ромашов // Університетські наукові записки НАУК-МА. 2007. № 4(24). C. 19. 
An important statement made in the framework of this theory is that law, as specific communication can exist without state, and state without law cannot exist. A.V. Polyakov, who is the author of the communicative theory of law, quite rightly states that "alongside state law there is a non-state law that has all the features of law, but at the same time, textual and functional features. Non-state law should include: corporate, sports, church and international law"18.

The communicative theory of law, not only reveals the essence of the relationship between the subjects, the order of implementation, which is reflected in legal algorithms, but also substantiates the need to use "nonstate law" in the process of regulating relations in society. Under analyze the provisions of the non-state (in our opinion, the term "soft law" is more apt), we can also establish the use of legal algorithms and technologies to ensure a proper way of communication and organization of legal activity.

A special place in the aspect of determining the methodological foundations of the study of legal algorithms, and technologies of legal activity is occupied by libertarian (libertarian-legal) theory of law developed by V.S. Nersesyanets. This theory very well substantiates the relationship, between the form and content of law, bringing as the central core of freedom, and formal equality.

V.S. Nersesyants defined the law, as "in accordance with the requirements of the principle of formal equality, a system of norms established or sanctioned by the state and secured by the possibility of state coercion. Law is a common and necessary form of human freedom, and freedom (its existence and realization) in social life is possible and valid only as a right and in the form of law"19.

There is no doubt that the obligatory condition for the implementation of quality legal activity is a formally expressed in the text legal act of a legal algorithms, which should not only be created in accordance with basic legal technologies, but also not contradict the ideas of justice, freedom, formal equality. Thus, the philosophical-theoretical constructs, proposed by V.S. Nersesyanets, make it possible to establish criteria for the relationship,between the "letter "and the "spirit" of socially significant prescriptions.

18 Поляков А. В. Общая теория права : курс лекций / А. В. Поляков. - СПб. : Юридический центр пресс, 2001. С. 327.

${ }^{19}$ Философия права: Учебник для вузов / В.С. Нерсесянц. 2-е изд., перераб. и доп. М.: Норма: НИЦ Инфра-М, 2013. С. 34. 


\section{Principles and methodological approaches to the research of legal algorithms}

Determined with the type of legal thinking, it is necessary to describe, those methodological constituents that was used in the process of research of legal algorithms, and technologies of realization of legal activity. In the marked aspect, the fully just is see realization of analysis of principles, approaches and methods, due to application of that it follows,to expose the characteristic signs of legal algorithms, and technologies of realization of legal activity, identify their place in legal reality.

The first basic principle, from which to begin research is the principle of historicism. Essence of legal algorithm and technologies of legal activity, it is possible to set on condition of consideration of features of his origin, forming and use in concrete historical condition and intercommunications. Systematized data in relation to historical genesis of legal algorithm, as historical phenomenon allow to represent all plenitude him social nature, to expose cause and effect connection of historical development of understanding of this meaningful instrument of formal expression of socially meaningful binding over's.

As marks H. M. Onishchenko, being base on principle of historical method, logical research of right exposes historical repetition, and general principles of their development. Therefore, any research of right in the basis, must be base on unity historical and logical. Logical determines the principles of approach to the historical, because it allows you to set the time of origin of law, to distinguish normative acts from customs, religious and moral norms ${ }^{20}$.

In turn, for establishment of features of intercommunication of legal algorithm and technologies of legal activity, with the system of the statelegal phenomena, it follows to apply principle of objectivity. Using this principle provides, not only a correct understanding of the nature of the relationship, between the subject and the object in the process of cognition, but also impartiality and deideologization of the research. The valued signs and descriptions of the investigated phenomenon, must be subject an analysis with the obligatory taking into account of achievements of civilization development of society. In addition, research objectivity, includes such elements as: modern society, legal reality, taking into account of that allows, to get to truth of presentation in relation to a role and place of legal algorithm in the system of adjusting of public relations.

\footnotetext{
${ }^{20}$ Оніщенко Н. М. Джерела права: теоретико-методологічні засади: дис...на здобуття наукового ступеня доктора юридичних наук за спеціальністю 12.00.01 - теорія та історія держави і права; історія політичних та правових учень / Наталія Миколаївна Оніщенко. Інститут держави і права ім. В. М. Корецького НАН України. Київ, 2009. С. 96.
} 
Taking into account modern progress of legal science, it's enriching trends to various knowledge, the special attention. it follows to spare principle of pluralism. The essence of this principle is revealed in the need, to apply various methods, concepts and approaches, in order to obtain a comprehensive understanding of the legal algorithm and technology of legal activity, their emergence, development and prospects. Than greater amount of criteria of analysis is used, the more reliable will be conclusions. It seems impossible, to generalize and formulate definition, on the basis of homogeneous indicators obtained from the research of the aspect of the phenomenon,under study from only one angle of view. It is necessary, to take into account,the maximal amount of existent looks to the problem, that is examined and to use totality of existent approaches, and methods with the aim of receipt complete, and balanced result.

Research principles form a certain base, on the basis of that general approaches, and concrete methods of realization of researches must be set forth taking into account the tendencies of modern legal science.

By a next element,that is to the constituents methodology of research has methodological approach. It should be noted, that in relation to determination of methodological approach,there is a certain discussion in modern jurisprudence.

A.F. Kryzhanovsky characterizes approaches, as "...foreshortening (in the wide understanding) of research vision, and thus, and the thoughts projections of object are certain cognitions that crystallize scientific strategy of understanding of right and legal phenomena, that is, the definition in general terms of the vector and the purpose of scientific research, as well as - its main stages and components"

By opinion of V.S. Bigun, methodological approach is a category more general for a method, and produced to the problem on the basis of certain theoretical theses, suppositions or concepts with the aim of search of optimal method of scientific search. At the same time, select a researcher approach determines the choice of concrete methods research and decision of problem $^{22}$.

Successful is determination, that is set forth A.O. Falkovsky, in accordance with that approach is the "form of organic combination of viewphilosophical orientation with a methodical tool, that is used in certain

\footnotetext{
${ }^{21}$ Крижановський А. Ф. Феноменологія правопорядку: поняття, виміри, типологія // Одес. нац. юрид. акад. О.: Фенікс, 2006. С. 23.

${ }^{22}$ Бігун В. С. Філософія правосуддя: ідея та здійснення: монографія / В. С. Бігун. К., 2011. C. 51.
} 
industry of research"23. From these positions essence of approach, does not close simple totality of methods (by methodology), but includes the components of the most general order, that is also included in bases of legal science.

Being based, on the marked principles in the process of establishment of essence legal algorithms, and technologies of legal activity, it follows to use various methodological approaches in particular: ideal-realistic, hermeneutics, valued, active, system and anthropological.

The ideal-realist approach is based on a complementary and holistic concept of knowledge of law, which in turn synthesizes ideas (metaphysics), facts (positivism) and appraisals (axiology) and is an attempt to understand the true combination of these most important legal spheres.

According to opinion V.V. Dudchenko, "in the methodology of idealrealistic synthesis, the confrontation between metaphysics and positivism is overcome, which allows one to know legal reality without its dogmatization, in its entirety. This approach leads us to the idea of a "normative fact". It is in this idea that the complexity of law finds its culminating point, and the phenomenon of law itself becomes accessible to understanding. At the same time, by solving the problem of "normative facts", it is possible to solve most of the urgent problems of modern law theory (problems of sources of law and definition of law according to its source, antinomies in the sphere of law, the role of organization and coercion, problems of correlation of public and private law, social law, legal pluralism, etc.). "On the basis of the above, the scientist formulates the ideal-realist concept of law as "a system, an order of imperative-attributive norms that acquire legitimacy, effectiveness and social guarantee of efficiency through normative facts" 24 .

Application of the ideal-realistic approach allows to reveal not only the view-ideological factors of the evolution of law, but also to determine the significance of its forms, features of their creation and implementation.

The hermeneutical approach is based on a set of principles and methods of interpretation and interpretation of legal texts,that can take the form of both legal and legal documents, and research of scientific works of scientists is equally important. Within the framework of hermeneutics approach possibility of opening features co-operation of subjects public relations is

${ }^{23}$ Фальковський А. О. Аксіологічний підхід в методології сучасної юриспруденції : автореф. дис. на здобуття наук. ступеня канд. юрид. наук.: спец. 12.00.12. "Філософія права" / А. О. Фальковський Нац. ун-т. Одес. юрид. акад. О., 2011. С. 7.

${ }^{24}$ Дудченко В. В. Традиція правового плюралізму: західна та східна інтерпретація : автореф. дис. ... д-ра юрид. наук: 12.00.01/ В. В. Дудченко; наук.консультант Ю. М. Оборотов; Нац. ун.-т “Одеська юридична академія”. Одеса, 2007. С. 5. 
created on the occasion not only creation of legal algorithm but also order of his realization.

Such model answers the task of the legal adjusting and allows to expose the elements of social nature of the investigated phenomenon.

On this occasion V. Dudchenko, specifies that, the "article of hermeneutics of right embraces interpretation of concept right, basic legal concepts, norms of right and legal facts with the aim of finding out of their sense" 25 .

The valued approach,allows to expose the certain system of values, due to the analysis of, that becomes possible a location and role of legal algorithm in legal reality. The valued analysis of legal algorithm must be based,on taking into account of such general social necessities and interests as: social justice, freedom, duty, orderliness, formal definiteness, state security and other. The use of the valued approach,allows to give the estimation of efficiency of legal algorithm, set his setting in regulation of public relation.

Active approach, in opinion of S.D. Gusarev, it is "harmonious totality of options, receptions, ensemble of methods, among that the method of activity is considered leading, and other in relation to him carry out an attendant role. This approach, allows to pay attention researcher,not only on a problem own to activity, but also on other phenomena, in correlation or co-operating with that there is activity. The aspects of including concrete type of activity are studied to the system of higher level, or taking of her to the certain type of social activity,and others like that, (social value, conditionality by development of public relations status, functional setting of activity or function of subject of activity, intercommunication of the functional setting and structure, description of the state, determination of criteria of efficiency, prospect of development, interaction)" ${ }^{\text {26 }}$.

Active approach, it follows to apply at correlating, between legal algorithms and legal activity, determination and application of technologies of their creation and realization.

The system approach, allows to conduct the all-round analysis of component parts of unit,that are in organic unity and co-operation. The system is constructed,as the organized orderliness of elements is based on their mutual ligaments and co-operation. At the use to methodology of the systematic approach static, structural, dynamic components and properties are investigated, them internal and external displays, genetic and functional

25 Дудченко В. В. Герменевтика права: розвиток юриспруденції : навч. посіб./ В. В. Дудченко, М. Р. Аракелян, В. В. Завальнюк. Одеса : Фенікс, 2014. С. 55.

${ }^{26}$ Гусарев С. Д. Юридична діяльність: методологічні та теоретичні аспекти : дис. ... д-ра юрид. наук: 12.00.01 / Київський національний ун-т внутрішніх справ. К., 2007. C. 64-65. 
ligaments, features of co-operating with external an environment. The system approach in investigational legal algorithm, allows to define him underlying structure, mechanism and features of action of his separate components as inter se so in co-operating with other constituents of legal reality (by a legal norm, by legal acts and other).

Anthropological approach in methodology of research technologies and algorithms legal activity is used as one of system-forming. Anthropology understands, as science about an origin and evolution of man. What touches legal anthropology, that is named yet anthropology of right, then she studies the processes of jurisdictions of human existence, predefined by the concrete historical types of civilizations. As a result, patterns are revealed that explain the main points associated with the legal life of mankind. Legal anthropology in its research is based,on the analysis of oral and written monuments of law, on the one hand, and the practice of public life, on the other.

So, according to opinion B.C. Nersesyantsa, "legal anthropology is the science of human as a social essence in its legal manifestations, measurements, characteristics. It studies the legal forms of social life of people from ancient times to this day. In its subject area includes legal systems, and in general - the whole complex of legal phenomena (all legal forms in the broadest sense of the word - legal rules, relationships, ideas and ideas, institutions, procedures, ways of regulating behavior, protecting order, solving conflicts, etc.), that are formed in different communities (primitive, traditional, modern), in different ethnic groups (peoples, nations), in different epochs and in different regions of the world. This provision is of fundamental importance in the study of legal systems, legal traditions and their diversity",27.

According to opinion V.V. Zavalnyuk, "the anthropological approach to research of human, culture and society is viewed from the point of view of the basic directions of anthropological knowledge - physical, philosophical, social and cultural anthropology, or simply from the point of view of the human dimension of the researched phenomena. The anthropological approach to human research in this context is related to the research point of view. In the content of the anthropological approach, includes the choice of object and subject, methodology and methods of cognition of man, culture and society. Anthropological approach is useful to overcoming of

${ }^{27}$ Нерсесянц В. С. Юридическая антропология как наука и учебная дисциплина : [предисловие] // Рулан Н. Юридическая антропология. Учебник для вузов // Перевод с франц. Ответственный редактор - академик РАН, доктор юридических наук, профессор. В. С. Нерсесянц. М.: Издательство НОРМА, 2000. С. 2. 
ethnocentric view to social development of man and societies, his use it is necessary pre-condition of adjusting of connections between with civilizations, legal systems, states and people that present different legal cultures. Anthropological knowledge are a considerable value for the modern mechanism of action of right, as anthropology comes forward as a certain kernel of rationalization and ideologization of culture. Legal anthropology is the product of activity of man, as gives possibility to learn public processes are certain and to influence on them, and also to use her potential in forming of legal reality ${ }^{28}$.

Fully correctly, V. N. Shapoval marks, that a "human is not a object, but subject of social actions, that through her and for her there are all surrounding transformations, that she is a not mechanism and not factor, but creature that has a mind and free will, then such position will be more friendly to understanding of sense of right, improvement of man and society ${ }^{29}$.

It is impossible to consider a right separately from a man, in fact essence the right is indissolubly related to fundamental principles of human life and cohabitation $^{30}$.

In the marked aspect, it follows to agree with the position of T.O. Podkovenko, that grounds, that "the existence of man in the world of law - here that comes forward as a reliable index of a civilized of any legal system $^{31}$.

Practical application of anthropological approach predetermines realization, based on humanistic principles, anthropological interpretation of legal norms. That in turn brings us over to opening of paradigms of legal anthropology, to which should be attributed: paradigm of man as to the center of right and criterion of the social normative regulation, paradigm of legal development, paradigm of structural functionality of legal environment of $\operatorname{man}^{32}$.

\section{The outcoming methods of research of legal algorithms}

Taking into account position and grounds set forth in principles and approaches becomes possible to define totality of methods due to application

28 Завальнюк В. В. Роль юридичної антропології у сучасному правовому розвитку /

В. В. Завальнюк // Актуальні проблеми держави і права. 2009. Вип. 47. С. 311.

29 Шаповал В. Н. Антропологічні виміри розвитку філософії права в Україні / В. Н. Шаповал // Проблеми філософії права. 2003. Т. 1. С. 130.

${ }^{30}$ Антропологія права: навч. Посіб. / В. І. Кушерець, В. М. Кравець, С. О. Мосьондз [та ін.]; за ред. В. І. Кушерця. К.: Знання України, 2011. С. 5.

${ }^{31}$ Подковенко, Т. О. Антропологічний підхід до права як основа юридичної науки [Електронний ресурс] / Т. О. Подковенко // Право і суспільство. 2015. № 2. С. 34.

${ }^{32}$ Пучков О. А. Юридическая антропология и развитие науки о государстве и праве:

Теоретические основі: диссертация ... доктора юридических наук: 12.00 .01 Екатеринбург, 2001. С. 64. 
of that opens up nature of legal algorithm. M.S. Kelman notes, that a method is the most wide, general approach to the study of that or other the and natural, and public phenomenon with application of that it is possible to score a success with every area of science. Methodological culture of lawyers it him world view maturity, sociological literacy, legal being informed and professional mastery ${ }^{33}$.

Being base on the declared principles and approaches in the process of opening of essence and social nature of legal algorithm and technologies of legal activity, it follows to use the next groups of methods : general methods of cognition; general-scientific methods; interdisciplinary methods ${ }^{34}$; specially-scientific methods of legal sciences.

From totality of general methods of cognition it follows to use: method of description for describe of legal algorithm by a reflection in a certain, in common understanding sign system, information regarding its nature and form; a method of comparison to establish the identity or distinction, between a legal algorithm and concepts such as: principle of law, legal act, model of behavior, formal expression of prescriptions, etc.; a method of generalization is for determination of general concept of legal algorithm with taking into account of all his properties and signs.

From the totality of general-scientific methods of cognition the special attention, it follows to the spare to the dialectical method, that predetermines objective, all-round, and concrete consideration of the legal algorithm with taking into account the inherent to him ties and exposure of interdependence of form and essence.

It follows to take into account that plenitude of scientific research legal algorithms and technologies of legal activity, related also to the use on all stages of such general-scientific methods as: analysis, synthesis, abstracting, generalization, induction, analogy.

From totality of interdisciplinary methods it follows to use: sociological method at establishment of concrete social facts and requirements of creation of legal algorithms; statistical method for quantitative description of cases of the use of legal algorithms in dispositions of principals of law in the legal system of Ukraine; concretely-historical at the studied specifics of origin, development and features of the use of legal algorithms at the social regulation.

${ }^{33}$ Кельман М. С, Мурашин О. Г. Загальна теорія держави і права: Підручник. К.: Кондор, 2006. С. 663.

${ }^{34}$ Крестовська Н. М., Матвєєва Л. Г. Теорія держави і права. Підручник. Практикум. Тести: підручник / Н. М. Крестовська, Л. Г. Матвєєва. К.: Юрінком Інтер, 2015. С. 30. 
Next to this, in research it is necessary to use the specially-scientific methods of legal sciences : hermeneutics method - for research of features of understanding and interpretation of legal algorithm in different historical periods, and with taking into account of approaches of different schools understanding of right; formally-dogmatic method - at the analysis of positions of legal facts and legal texts in relation to establishment of normative model of legal algorithm and order of his reflection in legal acts; comparatively-legal - for comparison of legal concepts, phenomena and processes, in relation to fixing of legal algorithms in legal acts that exist simultaneously in different countries, the analysis of features of organization and realization of legal activity.

\section{CONCLUSIONS}

In summary, it should be emphasized, that certain methodological tools are used to establish the order of creation of quality legal algorithms in accordance with existing legal technologies, requirements of society and provisions of legislation.

By opinion E. M. Oborotov, "Question of filling of methodology of jurisprudence by conceptual ideas, principles, approaches, methods, receptions, building connections the conceptual and instrumental level, "the statement of features methodology of the research activity is in the sphere of right and state,- it all presents the actual task of new correction to the complex of methodological problems, with moving towards a modern vision of methodology of jurisprudence",35.

\section{SUMMARY}

The noted type of legal thinking, principles, approaches and methods of scientific knowledge, reflect outcoming methodological principles of the research of algorithms and technologies of legal activity in modern law, and create the basis for obtaining comprehensive and complete information about their legal nature and social purpose.

\section{REFERENCES}

1. Антропологія права: навч. Посіб. / В. І. Кушерець, В. М. Кравець, С. О. Мосьондз [та ін.]; за ред. В. І. Кушерця. К.: Знання України, 2011. $223 \mathrm{c}$.

35 Методологія та інноватика загальнотеоретичної юриспруденції : монографія / [Ю. М. Оборотов, А. П. Овчиннікова, В.В.Завальнюк та ін.]; за ред. Ю. М. Оборотова.Одеса: Фенікс, 2019. С. 8 . 
2. Бігун В. С. Філософія правосуддя: ідея та здійснення: монографія / В. С. Бігун. К., 2011. 303 с.

3. Горобець К. В. Аксиосфера права: философский и юридический дискурс : моногр. / К.В. Горобец. Одесса : Фенікс, 2013. 218 с.

4. Гусарев С. Д. Юридична діяльність: методологічні та теоретичні аспекти : дис. ... д-ра юрид. наук: 12.00.01 / Київський національний унт внутрішніх справ. К., 2007. 422 с.

5. Дудченко В. В. Герменевтика права: розвиток юриспруденції : навч. посіб. / В. В. Дудченко, М. Р. Аракелян, В. В. Завальнюк. Одеса : Фенікс, 2014. 184 с.

6. Дудченко В. В. Традиція правового плюралізму: західна та східна інтерпретація : автореф. дис. ... д-ра юрид. наук : 12.00.01 / В. В. Дудченко; наук.консультант Ю. М. Оборотов; Нац. ун.-т “Одеська юридична академія". Одеса, 2007. 35 с.

7. Завальнюк В. В. Роль юридичної антропології у сучасному правовому розвитку / В. В. Завальнюк // Актуальні проблеми держави і права. 2009. Вип. 47. С. 309-312.

8. Кельман М. С, Мурашин О. Г. Загальна теорія держави і права: Підручник. К.: Кондор, 2006. 477 с.

9. Кельман М. С. Методологія сучасного правознавства: становлення та основні напрями розвитку : автореф. дис. докт. юрид. наук : 12.00.01 / М. С. Кельман. К., 2013. 42 с.

10. Керимов Д. А. Методология права: Предмет. Функции. Проблемы философии права / Д. А. Керимов ; ИГиП РАН. [2-е изд.]. М. : Аванта+, 2001. 559 с.

11. Ковтонюк А. М. Основні концепції права в інтегративній юриспруденції / А. М. Ковтонюк // Університетські наукові записки. 2007. № 4. C. 32-37.

12. Козюбра М. Праворозуміння : поняття, типи та рівень / М. Козюбра // Право України : Юрид. журн. 2010. № 4. С. 10-21.

13. Крестовська Н. М., Матвєєва Л. Г. Теорія держави і права. Підручник. Практикум. Тести: підручник / Н. М. Крестовська, Л. Г. Матвєєва. К.: Юрінком Інтер, 2015. 584 с.

14. Крижановський А. Ф. Феноменологія правопорядку: поняття, виміри, типологія // Одес. нац. юрид. акад. О.: Фенікс, 2006. 196 с.

15. Методологія та інноватика загальнотеоретичної юриспруденції : монографія / [Ю. М. Оборотов, А. П. Овчиннікова, В. В. Завальнюк та ін.]; за ред. Ю. М. Оборотова. Одеса: Фенікс, 2019. 420 с.

16. Нерсесянц В. С. Юридическая антропология как наука и учебная дисциплина : [предисловие] // Рулан Н. Юридическая антропология. Учебник для вузов // Перевод с франц. Ответственный редактор - 
академик РАН, доктор юридических наук, профессор. В. С. Нерсесянц. М.: Издательство НОРМА, 2000. 310 с.

17. Оборотов Ю. Праворозуміння як аксіоматичне начало (постулат) права / Ю. Оборотов // Право України. 2010. № 4. С. 49-55.

18. Оборотов Ю.Н. Філософія права і методологія юриспруденції / Ю.Н. Оборотов // Проблеми філософії права. 2003. Том 1. С. 41-43.

19. Общетеоретическая юриспруденция. Учебный курс : учеб. / под ред. Ю. Н. Оборотова. Одесса : Феникс, 2011. 436 с.

20. Оніщенко Н. М. Джерела права: теоретико-методологічні засади: дис...на здобуття наукового ступеня доктора юридичних наук за спеціальністю 12.00 .01 - теорія та історія держави і права; історія політичних та правових учень / Наталія Миколаївна Оніщенко. Інститут держави і права ім.. В. М. Корецького НАН України. Київ, 2009. $396 \mathrm{c}$.

21. Подковенко, Т. О. Антропологічний підхід до права як основа юридичної науки / Т. О. Подковенко // Право і суспільство. 2015. № 2. C. 32-38.

22. Поляков А. В. Общая теория права : курс лекций / А. В. Поляков. СПб. : Юридический центр пресс, 2001. 642 с.

23. Пучков О. А. Юридическая антропология и развитие науки о государстве и праве: Теоретические основы: диссертация ... доктора юридических наук: 12.00.01 Екатеринбург, 2001. 503 с.

24. Рабінович П. М. Методологія юридичної науки // Юридична енциклопедія. К., 2001. Т. 3. С. 618-627.

25. Рабінович П. Трансформація методології вітчизняного праводержавознавства: досягнення і проблеми / П. Рабінович // Юридична Україна . 2003. № 1. С. 10-18.

26. Ромашов Р. А. Реалистический позитивизм как интегративный тип современного правопонимания / Р. А. Ромашов // Університетські наукові записки НАУК-МА. 2007. № 4(24). С. 13-20.

27. Скакун О.Ф. Теорія держави і права: Підручник / Пер. 3 рос.Харків: Консум, 2001. 656 с.

28. Сливка С. С. Філософія права: методологічне осмислення / С. С. Сливка // Право України, 2011. N8. С. 61-70.

29. Теорія держави і права. Академічний курс: Підручник / За ред. О. В. Зайчука, Н. М. Оніщенко. К.: Юрінком Інтер, 2006. 688 с.

30. Фальковський А. О. Аксіологічний підхід в методології сучасної юриспруденції : автореф. дис. ... канд. юрид. наук : 12.00 .12 / А. О. Фальковський; кер. роботи Т. В. Розова; Нац. ун.-т “Одеська юридична академія". Одеса, 2011. 17 с. 
31. Философия права: Учебник для вузов / В.С. Нерсесянц. 2-е изд., перераб. и доп. М.: Норма: НИЦ Инфра-М, 2013. 848 с.

32. Шаповал В. Н. Антропологічні виміри розвитку філософії права в Україні / В. Н. Шаповал // Проблеми філософії права. 2003. Том 1. C. $129-130$.

33. Hall J. Integrative Jurisprudence. N.Y,. 1961. URL: https://www.repository.law.indiana.edu/cgi/viewcontent.cgi?article=2459\&c ontext=facpub

\section{Information about the author:} Manko D. G., Candidate of Juridical Sciences, Associate Professor at the Department of State and Law Disciplines, International Humanitarian University 33, Fontanska Road str., Odessa, 65009, Ukraine 


\section{ADMINISTRATIVE RESPONSIBILITY IN THE CONSTRUCTION INDUSTRY}

\section{Nenko S. S.}

\section{INTRODUCTION}

From an economic point of view, construction activity is a process of construction of buildings and structures, creating new enterprises, realize the expansion, reconstruction and technical re-equipment of existing enterprises and other objects the production sector and service sector, or in other words, it - economic activity, which includes forecasting, planning, design, construction of urban development, landscaping, expansion, technical reequipment of enterprises and provides the construction, reconstruction of residential, public and industrial buildings, structures and creates the basis for the development of all other spheres of the national economy.

\section{The concept and grounds of administrative responsibility in the construction industry}

The reform of the construction industry in the context of decentralization of the public administration system has influenced the gradual simplification of licensing and registration procedures, while expanding the powers of local governments and local Executive authorities in the field of architectural and construction control and increasing the responsibility of all participants in the construction process.

These changes are aimed at the proportionality of the application of the imperative and dispositive method in public relations in the construction industry. Due to this, considerable attention is paid to the formation of public-service relations in the industry under study, which are aimed at the interaction of the subjects of the construction process and inspection bodies. Public-service relations assume bilateral interaction of bodies of architectural and construction control and other subjects of construction process according to which one party has to provide the corresponding documents (the statement, the Declaration), and in the specified terms to make one of certain decisions, to provide permission, the certificate for construction or to refuse issue of allowing documentation.

With the help of public service relations, each of the parties is endowed, along with the rights, with certain obligations that are associated with the 
stages of construction. The most detailed can be their guide, guided by the stages of the construction process ${ }^{1}$ :

a) at the stage of preparatory works-in order to obtain the right to perform preparatory works, the customer submits a notification (Declaration) to the state architectural and construction control bodies, in turn the latter are obliged to enter it into the Unified register of documents, which gives the right to perform preparatory and construction works, and certifies the acceptance of completed construction projects into operation;

b) at the stage of construction works-the customer submits a notification (Declaration) or receives a permit, which is associated with the category of complexity of objects, in turn, the state architectural and construction control bodies are obliged to decide on the issuance or refusal to issue a permit for construction works and enter the data in the Unified register of documents, after which the customer can begin construction work;

c) at the stage of commissioning of completed construction projects, the customer submits a statement or receives a certificate about readiness of object for operation, which is associated with the complexity of objects; in turn, the authorities of the state architectural and construction supervision are required to make a decision about issuance or refusal to issue certificate for the construction work, and enter data in the Unified register of documents, then the customer may begin construction work.

This means that such relations are not built on a one-sided scheme of power-subordination, but on a two-way scheme of mutual right of claim belonging to both sides of legal relations ${ }^{2}$.

However, in case of violation or non-compliance with certain obligations by the subjects of the construction process at the appropriate stages, the inspection bodies have the right to apply appropriate administrative and coercive means of influence, among which the priority is given to administrative responsibility.

At present, the concept of administrative responsibility has a multi-vector orientation, connected, firstly, with the absence of its consolidation in the administrative-delict legislation; secondly, different approaches of scientists to its understanding and interpretation.

The concept of administrative responsibility is considered by scientists as one of the institutions of administrative law, as a form of ensuring one of the

\footnotetext{
${ }^{1}$ Isaenko D. Seven steps to decentralize the system of state Architectural control: teaching method. benefit. Kyiv: world Bank group 1818 N. Street N.W. Washington, D.C., 204ZZ, 2015. $64 \mathrm{p}$.

${ }^{2}$ Democratic foundations of public administration and administrative law: a monograph. / Y. Shemshuchenko, V. Averyanov, O. Andriyko, etc. Kyiv: Yurid. thought, 2010. 496 p.
} 
coercive measures, as a kind of legal responsibility, as an effective means of preventing offenses and ensuring law and order, as a certain state of public relations, which arises as a result of violation of legislation ${ }^{3}$. This list of starting categories, laid down in the interpretation of administrative responsibility, becomes the impetus for numerous discussions on this issue.

In turn, D. Lukyanets examines the Institute of administrative responsibility through administrative-tort relations, correlates the grounds of this type of legal responsibility with the elemental composition of legal relations. Detailing the specified conceptual approach, it identifies object of legal relations with object of an offense; their maintenance with the objective party of an administrative offense; the legal fact which underlies emergence of legal relations, with the subjective party of an offense. In the context of the above, he points to the ratio, but not the identification of relations administravtinogo offenses, administrative-tort relations and relations of administrative responsibility ${ }^{4}$.

Starting from the elemental structure of these legal relations, D. Lukyanets, defines the normative model of administrative responsibility, which consists of the General foundations and grounds for the emergence of administrative responsibility; the legal status of administrative jurisdiction and persons to whom penalties are applied; the procedural form of application and execution of penalties; principles and list of penalties.

In turn established categories operates T. Kolomoets, specifying administrative responsibility for the kind of legal liability, which is a specific form of negative response from the state represented by authorized bodies of the corresponding category of illegal actions (primarily of administrative offences), and the perpetrators of such crimes must answer before the authorized state body for its unlawful actions and to incur administrative penalties prescribed by the law and order ${ }^{5}$. This position of interpretation of administrative responsibility is laid down in the Academic course on administrative law (edited by V. Averyanov) ${ }^{6}$.

Along with this, Y. Bityak, V. Garashchuk and V. Bogutsky define administrative responsibility as a form of ensuring one of the coercive measures associated with the imposition on the offender of mandatory rules

\footnotetext{
${ }^{3}$ Course of administrative law of Ukraine: studies. / V. Kolpakov, O. Kuzmenko, I. Pastukh et al. Kyiv: Yurinkom inter, 2012. 808 p.

${ }^{4}$ Lukyanets D. Development of the Institute of administrative responsibility: conceptual foundations and problems of its implementation: dis. ... the doctor said. Sciences: 12.00.07. Kiev, 2007. 435 p.

${ }^{5}$ Kolomoets T. Administrative law of Ukraine. Academic course: studies. Kyiv: Yurinkom Inter, 2011. 576 .

${ }^{6}$ Bostan L. M. History of state and law of foreign countries: studies. Handbook / L. Bostan, S. Bostan. Kyiv: center of educational literature, 2004. 672 p.
} 
in force in the state administration, administrative penalties, entailing for these person's burdensome consequences of a material or moral nature ${ }^{7}$.

The starting point for imposing administrative penalties is violations of the normative rules in the public administration, which thus provides for the prosecution of officials of public authorities in most cases.

With regard to this, S. Petkov notes that in modern conditions of the state, the subject of management is responsible for all adverse consequences caused by illegal or inept use of power. In this regard, the institution of administrative responsibility should be directed to the definition and ordering of administrative offenses, the subject of which a priori can only be an official of public authorities. Thus, speaking about administrative responsibility, it should be noted that it is the responsibility of officials of public authorities.

Developing this position, some scientists note that the subject of responsibility for such offenses is an ordinary citizen. Regarding this, there are numerous discussions, which are reflected in the proposals for the construction of an updated code on administrative responsibility, the subject of administrative offenses in accordance with which officials of public authorities should become.

Summarizing the above, we note that administrative responsibility is a purely legal phenomenon, generated by the legal regulation of the relevant relations. And as a legal phenomenon, administrative responsibility in the construction industry is characterized by two groups of signs. The first group is the signs inherent in the whole of administrative responsibility. The second group-features that distinguish administrative responsibility in the construction industry from administrative responsibility in other spheres of public life ${ }^{8}$.

In the science of administrative law formed several views on administrative responsibility in the construction industry. Let us draw attention to the fact that representatives of the science of administrative law, considering administrative responsibility in the construction industry, reveal only the General features of administrative responsibility. This approach has its negative consequences, because the specificity and features of administrative responsibility in the construction industry are lost. And as a consequence of this one-sided understanding of administrative responsibility in the field of construction, problems may arise in the practical implementation of administrative-tort norms.

\footnotetext{
${ }^{7}$ Administrative law: studies. / Y. Bytyak, V. Garashchuk, V. Bogutskaya, etc. Kharkiv: Pravo, 2010. 624 p.

${ }^{8}$ About attraction to administrative responsibility for violation of the town-planning legislation. Comparative-analytical law. 2013. No. 4/1. P. 241-243.
} 
At the same time, representatives of the science of construction law, considering administrative responsibility, focus mainly on the specific features of this responsibility in the construction industry, ignoring the General properties of administrative responsibility.

Such an approach can lead to the fact that the legislator will not take into account in his law-making activities the General trends in the development of the institution of administrative responsibility, and only try to settle relations in the construction industry, which is in a state of constant reform. It is like trying to examine the whole by its individual manifestations, but without forming a clear idea of the whole as such. However, it is necessary to find out what makes it possible to create a holistic view of administrative responsibility ${ }^{9}$ in the construction industry.

That is why, characterizing administrative responsibility in the construction industry, it is necessary to take into account the theoretical developments of legal science in General and the norms of administrative law and legislation on construction activities.

Administrative offenses in the studied industry are characterized by common features inherent in any administrative offenses. However, a number of scientists highlight the features inherent in administrative responsibility in construction activities, which they include:

(a) the specific scope of administrative responsibility - construction activities;

(b) the subjects of administrative responsibility are individuals, officials and legal entities;

(c) application of penalties only of property character ${ }^{10}$.

A significant difference that allows you to select them in an independent group, from the point of view of life. M. Semenko, is the object of encroachment, that is, public relations existing in the field of construction, and its normal uninterrupted work ${ }^{11}$.

In the theory of administrative law as the object of an administrative offense is determined by what encroaches administrative offense, namely the range of protected by administrative legislation of public relations ${ }^{12}$.

${ }^{9}$ Lukyanets D. Administrative-tort relations in Ukraine: theory and practice of legal regulation: monograph. Sumy: VTD "University book", 2006. 367 p.

${ }^{10}$ Tropina G. Legal nature of administrative responsibility in the field of construction. European perspective. 2013. No. 9. Pp. 79-86.

${ }^{11}$ Semenko B. administrative responsibility for offenses in the field of construction: dis. Cand. J. Sciences: spec. 12.00.07 "Administrative law and process; financial law; information law". Zaporozhye, 2011. 193 p.

${ }^{12}$ Mikolenko A. Administrative process and administrative responsibility in Ukraine: studies. Benefit. Kharkiv: Odyssey, 2006. 352 p. 
Analyzing the specified provision, it is necessary to stop in more detail on the analysis of the types of objects of administrative offenses defined in the theory of administrative law in the investigated direction: General, generic and direct.

The General object covers a circle of the public relations defined in tasks of the Code of Ukraine about administrative offenses (Art. 1) and defined within concept of an administrative offense (Art. 9.) ${ }^{13}$. From a doctrinal point of view, it includes all public relations (administrative, labor, financial, etc.) protected by administrative law ${ }^{14}$. In this regard, a very erroneous point of view is to reduce it only to public relations of a managerial nature. Interpreting this as a circle of protected public relations in the construction industry, I. Mironets to public relations, forming a common object, refers only to the sphere of state management of construction activities, which is regulated by regulations ${ }^{15}$. However, we must not forget that administrative offenses actually encroach on other social relations (regulated, for example, by the norms of constitutional, financial, labor law), which are also protected by administrative and legal means ${ }^{16}$. In this regard, a common object in the studied direction is the range of public relations in the construction industry, which are protected by administrative and legal norms.

The generic object is a group of homogeneous public relations aimed at the realization of the rights and freedoms of citizens, ensuring the established order of management, formation and development of a fullfledged human environment, through the sustainable development of human settlements, landscaping, nature protection and cultural heritage, the use of natural resources, coordination of state, public and private interests. In some scientific works, the definition of generic object in the studied direction is carried out within the framework of public relations in the field of capital construction $^{17}$, is limited to the administrative offenses specified in Chapter 8 "Administrative offenses in the industry, construction and in the field of use of fuel and energy resources". The opposite view supported by a

${ }^{13}$ Code of Ukraine on administrative offences. Information of the Supreme Soviet of the USSR. 1984. Annex to No. 51. P. 1122 (with the following modifications and additions).

${ }_{14}$ Administrative law of Ukraine. Academic course: studies.: in 2 t. / per zag. ed. Averyanova. Kiev: The Faculty Of Law. thought, 2004. Vol. Common part. 584 p.

${ }^{15}$ Mironets I. Administrative and legal regulation of construction activity in Ukraine: dis. ... the candidate is legal. Sciences : 12.00.07. Kiev, 2012. 235 p.

${ }^{16}$ Kostrubitska A. There is Administrative responsibility for law-violations in the fuel and energy complex of Ukraine: dis. ... the candidate is legal. Sciences: 12.00.07. Kiev, 2009. 222 p.

${ }_{17}$ Kropacheva A. Administrative responsibility for violations in the field of capital construction: abstract. dis. on competition of a scientific degree - nie Kazan. the degree candidate. Yuri. Sciences: spec. 12.00.14 "Administrative law; administrative process". Moscow, 2013.20 p. 
large number of scientists, focusing on the branching of administrative violations in the construction industry within at least five chapters of the Cao, which indicates the inter-industry focus in legal relations ${ }^{18}$.

Defining the direct object, it is necessary to emphasize its individuality for each administrative offense in the construction industry, as an examplethis is public relations in the field of land use of road transport, subsoil protection, use of land of the state forest Fund, the sphere of management of the construction industry. At the same time, this is the established procedure for conducting a comprehensive examination of project documentation for construction, obtaining permits, investment activities in construction and the like. The scope of the direct object is clearly defined circle protected by the administrative norm of public relations, which are harmed by a specific offense related to the implementation of construction activities.

Thus, it should be noted that construction activity is associated with a set of labor, land, financial, civil, economic relations, for example, the allocation of land for construction; regulation of financial mechanisms for investment in housing construction. In this regard, it should be noted that the composition of administrative offenses in the construction industry on the object of illegal encroachment can be systematized into two groups: group 1-public relations, regulated directly by the construction legislation; Group 2-social relations regulated by other branches and institutions of law, but they arise in connection with the implementation of construction ${ }^{19}$.

Considering the external signs and circumstances that form an administrative offense, we focus on the analysis of the objective side of the element component, which includes acts (action or inaction), the harmful consequences of the offense, the causal consequences between them.

The analysis of the objective side of administrative offenses in the construction industry gives grounds to group them into the following groups: violation of mandatory requirements of state standards, specifications, building codes and rules (construction legislation) at all stages of the construction process; violation of sanitary-epidemiological, environmental, fire-prevention norms and rules of improvement during construction; unauthorized construction; - violation of the procedure for; violations related to the order of implementation of copyright and technical supervision; violations related to failure to comply with the legal requirements of officials; other violations related to the construction process.

18 Nizankowska N. Administrative liability for offenses in the sphere of housing construction : abstract. dis. on the receipt Kazan. the degree candidate. Yuri. Sciences: spec. 12.00.14 "Administrative law; administrative process". Khabarovsk, 2011. $20 \mathrm{sec}$.

19 Parmenov S. Administrative responsibility in the construction industry. Republican construction newspaper. 2012. No. 39 (492). 
Considering the specified acts which in total form the objective party of administrative offenses in construction branch, once again it is necessary to focus attention on the interpectoral direction of the corresponding branch. Separate from the specified illegal acts form structures of transport, housing, land and offenses in the sphere of nature management, for example violation of the approved town-planning documentation at allotment of lands and the illegal actions of the officials and legal entities which have entailed unauthorized occupation of lands (Art. 211 of the Land code of Ukraine) ${ }^{20}$. All this in a complex indicates the need to allocate a separate block of misconduct in the construction industry.

Subjects of administrative responsibility in the construction industry can be both individuals and legal entities. Depending on the stage of the construction process, during the implementation of which an administrative offense is committed, there are such subject composition ${ }^{21}$ : at the design stage - design organizations, chief architect of the project, chief engineer of the project, expert organizations, officials of expert organizations, organizations providing technical conditions; at the stage of implementation of preparatory works - the customer, officials of the customer, contractor, officers, contractors, officials exercising technical supervision, the officials carrying out supervision; at the stage of construction work - the customer, officials of the customer, contractor, officers, contractors, officials exercising technical supervision, the officials exercising supervision; at the stage of production and manufacture of building materials, products, structures - legal entities and individuals-entrepreneurs, individuals and officials; at the stage of operation of completed construction facilities-legal entities and individuals-entrepreneurs, individuals and officials.

At the same time, analyzing the subject structure of administrative offenses in the construction industry, they can be classified depending on the direction of personal activity in the construction industry. Such subjects include: subjects of urban development, engaged in the design of objects, the examination of construction projects; subjects of urban development, which are customers of the construction of objects (in the case of urban development activities), or performing the functions of the customer and the contractor at the same time; subjects of urban development, performing construction work; the subjects of urban development, which carry out economic activity, connected with creation of architectural objects is subject

\footnotetext{
${ }^{20}$ Korneev Y. Land law: studies. benefit. 2nd view. processing. Kyiv: center of educational literature, 2011. $248 \mathrm{p}$.

${ }^{21}$ Isaenko D. Seven steps to decentralize the system of state Architectural control: teaching method. benefit. Kyiv: world Bank group 1818 N. Street, N.W. Washington, D. C., 204ZZ, 2015. 64 p.
} 
to licensing, or entrust the execution of certain types of works the responsible executors which under law must have the qualification certificate; the subjects of urban development that produce building materials, products and structures; subjects of urban development, attracted by the Central body of Executive power that implements the state policy on state architectural-building control, to audit; the enterprises providing technical conditions on engineering support of object of construction, etc.

Given the reconstruction of administrative-tort legislation in the studied direction is offered within the separate chapters of the administrative code "Administrative offences in construction industry" include: compositions of administrative offenses relating to violations in the sphere of protection of natural resources during construction; the compositions of administrative offenses relating to violations of fire, sanitary-epidemiological, environmental supervision at construction sites and adjacent to a building site; warehouses of administrative offenses concerning improvement of settlements (violation of arrangement of the adjacent territory to the construction object, damage to the adjacent transport infrastructure by construction works, etc.); warehouses of administrative offenses concerning violations on creation of engineering and transport infrastructure within the construction object; the compositions of administrative offenses relating to housing rights and freedoms of citizens (alteration and reconstruction of buildings, damage to premises); the compositions of administrative offenses relating to violations in the creation of unhindered living environment for persons with disabilities and other disabled groups; the compositions of administrative offences related to the exercise of architectural control, technical supervision and other regulatory powers of public authorities related to the construction; the compositions of administrative offences of non-compliance with energy efficiency and energy conservation construction projects; the components of administrative offences related to the financing of construction; the components of administrative offences, related with connecting to infrastructure construction projects; the components of administrative offences related to publicize activities and providing administrative services in the construction industry.

An integrated approach in building this Chapter aims to systematize the scattered under the construction law and the administrative code of administrative offenses related to construction.

\section{Administrative liability procedures in the construction industry}

Gradual steps towards reforming relations in the construction industry were the impetus for the transfer of construction control and supervision from the national level to the local. This restructuring of the system of state 
supervision over decision - making in the field of urban planning and proper state architectural and construction control requires the introduction of effective and transparent administrative and jurisdictional procedures in the construction industry. The substantive basis of administrative and jurisdictional procedures are administrative liability procedures in the construction industry, aimed at the consideration of cases of administrative offenses.

The definition of the essence and content of administrative and jurisdictional procedures in the construction industry should be investigated through the formation of scientific views on the identification of the concepts of "process", "production" and «procedure". The reason for the detailed analysis of General theoretical concepts of the administrative process is the study of the most established doctrine of administrative law approaches to the essence and content of the categories "administrative process", "administrative proceedings", "administrative procedure" 22.

Stages of implementation of the procedure for consideration of cases of administrative offenses: initiation of a case of an offense in the construction industry; consideration of a case of an offense in the construction industry; appeal against the decision to impose a fine and the decision to close the case; execution of the decision.

And the stage is the initiation of a case of an offense in the construction industry. In this stage it is possible to allocate the following procedural stage: a) preliminary administrative investigation during which carrying out there is an identification and suppression of an offense, fixing of traces on a scene, interrogation of eyewitnesses; b) investigations: drawing up the Protocol, selection of explanations, withdrawal of things and documents (collection of proofs), fixing of results of investigation in procedural documents; c) transfer of business on jurisdiction for consideration.

Stage II-consideration of the case of an offense in the construction industry. At this stage is preparing the case for review, during which an official body of the state architectural and construction control: studying the case materials and determines the competence of the case; ascertain the correctness of the Protocol; organizes the notification to the subject of urban development, who shall be held liable and other persons participating in the proceedings, the time and place of the hearing; met with proof, carries out the reclamation of necessary additional materials; finds out, whether petitions (in the presence) of the subject of town-planning brought to

${ }^{22}$ Semenko B. administrative responsibility for offenses in the field of construction: dis. Cand. J. Sciences: spec. 12.00.07 "Administrative law and process; financial law; information law". Zaporozhye, 2011. 193 p. 
responsibility, or other persons participating in business are subject to satisfaction.

Stage III-appeal against the decision to impose a fine and the decision to close the case. An important guarantee of the legality and validity of the application of administrative penalties is the presence of the stage of revision of resolutions. This stage has a special place in the structure of proceedings in cases of administrative misconduct. Under review understand consideration of cases by bodies entrusted with the control over the legality of decisions on cases of administrative offenses or re-examination of cases by bodies that have made a decision ${ }^{23}$.

Stage IV - implementation of the resolution. The final stage of proceedings in cases of administrative misconduct in the construction industry is the execution of decisions on the imposition of administrative penalties.

\section{Penalties in the construction industry}

In Ukraine there is a need for purposeful activities of the state towards the development of those industries that can provide multiplicative effect in adjacent areas and, as a consequence, the economic growth of the country. One such industry is construction.

Construction is the material basis for improving the level and quality of life of the population, which is proclaimed in Ukraine the goal of long-term socio-economic policy of the state. The current situation allows us to state the insufficient efficiency of regulation of market relations in the construction sector. This requires additional studies of current trends in the development of construction in order to improve the forms, methods and tools of state influence on the transformation and market processes in the construction industry in the direction of compliance with the requirements established by legislation, building codes, state standards and rules.

Administrative responsibility in the construction industry is one of the important tools to ensure compliance with the above requirements, enshrined in state standards, building codes and regulations. This type of administrative responsibility is implemented by imposing administrative penalties on the guilty subjects of the construction process.

Administrative penalties are punitive, "punitive" sanctions, which usually consist in deprivation or restriction of certain rights, benefits, education of a person in the spirit of compliance with the laws of Ukraine,

\footnotetext{
${ }^{23}$ Stukalenko O. Administrative responsibility for violation of norms of the land legislation (material and procedural aspect): dis. ... candidate of Jurid. Sciences: 12.00.07. Odessa, 2008. $181 \mathrm{c}$.
} 
respect for the rules of the hostel, as well as prevention of committing new offenses both by the offender and by other person ${ }^{24}$. Thus the purpose of administrative penalty fixed by art. 23 .

The Code of Ukraine on administrative offences does not define the concept of "administrative restraint", stopping only at its purpose and types. Therefore, within the scientific literature there are different approaches to the interpretation of this concept. One group of scientists defines administrative sanctions because of the analysis of adverse legal consequences for the damage caused to administrative offenses (V. Averyanov, S. Pektvov) ${ }^{25}$. Another group investigates them through the material manifestation of administrative responsibility (O. Andriyko, D. Lukyanets, S. Stetsenko) ${ }^{26}$. In another aspect, administrative sanctions are investigated because of the component of administrative coercion (A. Komzyuk, T. Kolomoets, D. Priymachenko ${ }^{27}$. Along with this N. Khoroshchak summarizes the above approaches to the concept of administrative penalties in institutional, regulatory and legal aspects ${ }^{28}$.

The indicated approaches of scientists are actually reduced to a synonymous interpretation of the concept of administrative penalties from the position of the component of the legal norm, administrative responsibility, state coercion.

Within the framework of article 24 of the administrative Code, a certain system of administrative penalties: warning, fine, penalty points, compensated seizure of the object, confiscation, deprivation of a special right, community service, correctional labor, administrative arrest, arrest with detention in the guardhouse. This system of administrative penalties includes different in nature and legal consequences of sanctions, which allows to take into account when imposing penalties as features of the committed administrative offense and features of the offense ${ }^{29}$.

${ }^{24}$ The code of Ukraine on administrative offences: scientific and practical commentary / G. Kalyuzhny, A. Komzyuk, A. Pogrebnoy et al. 2nd ed. Kyiv: all-Ukrainian Association of publishers "Legal unity", 2008. 655 p.

${ }^{25}$ Administrative law of Ukraine. Academic course: studies.: in 2 t. / per zag. ed. Averyanova. Kiev: The Faculty Of Law. thought, 2004. Vol. Common part. 584 p.

${ }^{26}$ About attraction to administrative responsibility for violation of the town-planning legislation. Comparative-analytical law. 2013. No. 4/1. Pp. 241-243.

${ }^{27}$ Administrative responsibility in Ukraine: studies. allowance / per zag. ed. The 2nd kind., exp. Kharkov, 2001. 112 p.

${ }^{28}$ Harosak N. Administrative penalty according to the legislation of Ukraine: monograph. Kyiv: Institute of state and law. V. Koretsky NAS of Ukraine, 2004. 172 p.

${ }^{29}$ The code of Ukraine on administrative offences: scientific and practical commentary / G. Kalyuzhny, A. Komzyuk, A. Pogrebnoy et al. 2nd ed. Kyiv: all-Ukrainian Association of publishers "Legal unity", 2008. 655 p. 
Some of the above administrative penalties are imposed for violations in the construction industry.

Among the penalties provided by the current legislation for offenses in this area, fines occupy a prominent place and are the most common type of penalties. So, about administrative responsibility in construction, as M. Mironets notes, it is possible to speak mainly as about a penalty ${ }^{30}$.

In the framework of legislation and scientific literature provides a comprehensive interpretation of the concept of a penalty. Thus, in part 1 of article 230 of the Economic code of Ukraine penalties are defined as economic sanctions in the form of a sum of money (penalty, fine, penalty), which the participant of economic relations is obliged to pay in case of violation of the rules of economic activity, failure or improper performance of economic obligations ${ }^{31}$. Within the framework of this codified act, various types of implementation of economic sanctions in the form of penalties, fines, penalties are defined.

Thus, within the framework of the legislation, penalties are implemented in the form of a fine, penalty, penalty. The form of implementation of the penalty depends on the industry in which it is implemented. Taking this into account, the scientific literature distinguishes economic, financial and administrative sanctions, thus highlighting a certain kind of economic penalty, financial penalty, administrative penalty and civil penalty liability.

Taking into account the above, penalties are the implementation of the component of the legal norm, material and monetary sense, which is applied for violation of construction norms, rules and standards at all stages of construction activities to the subjects of the construction process, individuals, individual entrepreneurs, officials, legal entities.

The penalty is punitive in nature, not restorative. Committing an administrative offense in the construction industry, the subject pays a certain amount of money within the framework of the legislation, which is calculated in a clearly defined number of non-taxable minimum incomes of citizens, minimum wages and the like.

With the help individualization responsibility necessarily require installations such facts ${ }^{32}$ :

- the nature of the offense in the construction industry;

${ }^{30}$ Mironets N. Penalty liability for administrative offenses in construction activities. Lawyer. 2010. No. 6 (117). P. 34-38.

${ }^{31}$ Economic code of Ukraine of 16 January 2003 No. 436-IV. Sheets Of The Verkhovna Rada Of Ukraine. 2003. № 18, № 19-20, № 21-22. P. 144.

32 The code of Ukraine on administrative offences: scientific and practical commentary / G. Kalyuzhny, A. Komzyuk, A. Pogrebnoy et al. 2nd ed. Kyiv: all-Ukrainian Association of publishers "Legal unity", 2008. 655 p. 
- the person of the offender (natural person, natural personentrepreneur, official, legal entity);

- the extent of her guilt;

- property status (specialized participant in the construction process or an individual);

- circumstances mitigating or aggravating punishment.

Along with this, responsibility for some violations is differentiated depending on the complexity category of the construction object - the more complex the object, the higher the penalty. This approach can generally be considered justified within the framework of domestic legislation. But the question arises, how will the size of the fine be determined if the complexity category of the object in respect of which the violation took place is not defined ${ }^{33}$.

Analysis of penalties in the construction industry indicates significant shortcomings associated with: violation of the procedure for imposing fines; determination of their size; non-compliance in most cases, the purpose rules for imposing penalties for administrative offenses in the construction industry, which, in turn, violates the principles on which administrative responsibility is based (the principle of legality, the principle of individualization of responsibility).

Everything specified in the complex indicates the need to improve the procedure for imposing and determining the size of penalties. Thus, it is necessary:

1) to improve the procedure for imposing on the subject of urban development two or more fines for each committed administrative offense in the construction industry. Analysis of judicial practice in this regard indicates the need to coordinate the procedure for the simultaneous accrual of penalties for each offense committed in the construction industry. At the same time, the absence of a unified system in determining the composition of administrative offenses in the study area leads to the simultaneous drafting of the Protocol on administrative offense and the Protocol on offense in the field of urban development for similar offenses. The question on the simultaneous involvement of urban planning, primarily individuals for the same offense separately defined under the administrative code and the Law of Ukraine "On liability for violations in the field of urban development." This direction requires improvement in terms of systematization of offenses in the construction industry within the Construction code;

${ }^{33}$ Igonin V. Some novelties of the new law on liability for violations in the field of urban development. Legal newspaper. No. 7. 
2) agree on the amount of penalties defined in the administrative code and construction legislation. To this end, it is proposed within the framework of the Chapter of the Construction code to determine the list of offenses in the construction industry, detailing the subject of the offense (citizens, officials, individuals, entrepreneurs, legal entities). Taking into account the legal status of the above-mentioned subjects of the construction process, observing the implementation of the principles of administrative responsibility (legality, individualization), it is necessary to clearly delineate the boundaries of penalties for each offense, taking into account the subject of the construction process, which is brought to justice;

3 ) in order to harmonize the use of construction terminology within the disposition of articles, it is necessary to define it in detail in the conceptual apparatus of the code, which will avoid unnecessary confusion during its enforcement in the activities of jurisdictional bodies. This inconsistency significantly affects the detail within the Protocol on administrative offense, the legal norm that is violated, and also creates unnecessary confusion during the simultaneous Commission of two or more offenses by the subject of urban development. Along with this, it is necessary to coordinate the use of separately defined concepts "administrative offense in the construction industry" and "offenses in the field of urban development" within the framework of administrative and tort legislation, when committing which procedural documents are different in content. For the purpose of settlement of the specified question within the basic provisions of the Building code of Ukraine it is necessary to define the basic terms which are applied in dispositions of articles of administrative Code and the Law of Ukraine "about responsibility of subjects of town-planning". To harmonize the terminology used in the administrative-tort legislation, it is necessary to define the following concepts: administrative offense in the construction industry; state standards in the construction industry; building regulations; building rules and the like.

\section{CONCLUSIONS}

The study of administrative responsibility in the construction industry allows us to draw conclusions:

1. The analysis of the concept of administrative responsibility is carried out taking into account the existing scientific views on its content as one of the institutions of administrative law, as a component of administrative coercion as a type of legal responsibility, as a means of preventing offenses. Guided by established scientific views on the essence and origin of the specified legal category, we believe it is necessary to define the concept of 
administrative responsibility in the construction industry - as institute administrative responsibility, which is based on ALCO and building legislation, is implemented for the Commission by the subjects of construction process of administrative misconduct in the construction industry for which the competent public authorities in procedural order impose administrative penalty.

2. The grounds of administrative responsibility in the construction industry are considered: a) normative (legal); b) actual; c) procedural.

3. Factual basis. It is based on the concepts and elemental structure of the administrative offense in the construction industry (object, objective side, subject, subjective side).

4. The introduction of a number of socio-economic and legal reforms aimed at using the latest technologies in construction, increasing the level of optimization of the use of energy and natural resources, creating an unhindered living environment for people with limited mobility, comprehensive compliance with sanitary-epidemiological, fire-prevention norms and rules of improvement during construction, affects the emergence of new types of administrative offenses in the construction industry, for which it is necessary to establish responsibility. At the same time, the adaptation of the legislation of Ukraine to the legislation of the leading countries of the world requires appropriate steps to reform the administrative-tort legislation with the allocation of administrative offenses in the construction industry and bringing the construction legislation to a single system.

5. Within the framework of jurisdictional proceedings, a certain set of procedurally formed actions, administrative procedures aimed at the consideration of cases of administrative offenses is implemented.

The procedure of administrative responsibility in the construction industry should be defined as a set of clearly formed and consistent actions (stages), United by a common goal, during which the legal protection of the violated or disputed right is carried out, a legally authoritative decision is made, sanctions are applied, the violated right is restored in the process of considering an administrative case in the construction industry.

6. Describes the stages of implementation of the procedure of consideration of cases on administrative offences, which should include: the initiation of misdemeanor proceedings in the construction industry; the proceedings on offense in the construction industry; the appeal of the decision to impose a fine and orders to close the case; the execution of the decision. 


\section{SUMMARY}

The article is devoted to the study of modern views on administrative and legal support of the construction industry in the context of adaptation of the legal system in accordance with the "acquis communautaire". The problems of formation, formation and further development of the construction industry are investigated, trends and directions of improvement of administrative and legal support of construction activities are determined taking into account international standards.

The article focuses on the need to update the substantive provisions of the administrative and legal support of the construction industry by means of theoretical principles, elements of its mechanism, the system of subjects of construction activity, coordination of the provisions of administrative and tort legislation, as well as priority areas of harmonization of the current legislation with international provisions. The priority steps to improve the administrative and legal support of the construction industry in Ukraine are considered. Provides suggestions for improvement of the current legislation, in particular defined a comprehensive approach to the construction Chapter of the administrative code, as well as justifies the project structure and disclosed the main content of the Construction code, the scope of which covers the legal foundations of urban planning, construction engineering and other facilities in Ukraine.

\section{REFERENCES}

1. Administrative responsibility in Ukraine: studies. allowance / per zag. ed. The 2nd kind., exp. Kharkov, 2001. 112 p.

2. Administrative law: studies. / Y. Bytyak, V. Garashchuk, V. Bogutskaya, etc. Kharkiv: Pravo, 2010. 624 p.

3. Administrative law of Ukraine. Academic course: studies.: in 2 t. / per zag. ed. Averyanova. Kiev: The Faculty Of Law. thought, 2004. Vol. Common part. 584 p.

4. Bostan L. M. History of state and law of foreign countries: studies. Handbook / L. Bostan, S. Bostan. Kyiv: center of educational literature, 2004. $672 \mathrm{p}$.

5. Gnatyuk S. Stages of proceedings in cases of administrative offenses: dis. ... the candidate is legal. Sciences: 12.00.07 / Gnatyuk Stepan Sergeevich. New York, 2010. 228 p.

6. Economic code of Ukraine of 16 January 2003 No. 436-IV. Sheets of the verkhovna rada of Ukraine. 2003. № 18, № 19-20, № 21-22. Pp. 144.

7. Democratic foundations of public administration and administrative law: a monograph. / Y. Shemshuchenko, V. Averyanov, O. Andriyko, etc. Kyiv: Yurid. thought, 2010. 496 p. 
8. Igonin V. Some novelties of the new law on liability for violations in the field of urban development. Legal newspaper. No. 7.

9. Isaenko D. Seven steps to decentralize the system of state Architectural control: teaching method. benefit. Kyiv: world Bank group 1818 N. Street N.W. Washington, D.C., 204ZZ, 2015. 64 p.

10. Code of Ukraine on administrative offences. Information of the Supreme Soviet of the USSR. 1984. Annex to No. 51. Pp. 1122 (with the following modifications and additions).

11. The code of Ukraine on administrative offences: scientific and practical commentary / G. Kalyuzhny, A. Komzyuk, A. Pogrebnoy et al. $2^{\text {nd }}$ ed. Kyiv: all-Ukrainian Association of publishers "Legal unity", 2008. $655 \mathrm{p}$.

12. Kolomoets T. Administrative law of Ukraine. Academic course: studies. Kyiv: Yurinkom Inter, 2011. 576 p.

13. Korneev Y. Land law: studies. benefit. -2 nd view. processing. Kyiv: center of educational literature, 2011. $248 \mathrm{p}$.

14. Kostrubitska A. There is Administrative responsibility for lawviolations in the fuel and energy complex of Ukraine: dis. ... the candidate is legal. Sciences: 12.00.07. Kiev, 2009. 222 p.

15. Kropacheva A. Administrative responsibility for violations in the field of capital construction: abstract. dis. on competition of a scientific degree - nie Kazan. the degree candidate. Yuri. Sciences: spec. 12.00.14 "Administrative law; administrative process". Moscow, $2013.20 \mathrm{p}$.

16. Course of administrative law of Ukraine: studies. / V. Kolpakov, O. Kuzmenko, I. Pastukh et al. Kyiv: Yurinkom inter, 2012. 808 p.

17. Lukyanets D. Administrative-tort relations in Ukraine: theory and practice of legal regulation: monograph. Sumy: VTD "University book", 2006. $367 \mathrm{p}$.

18. Lukyanets D. Development of the Institute of administrative responsibility: conceptual foundations and problems of its implementation: dis. ... the doctor said. Sciences: 12.00.07. Kiev, 2007. 435 p.

19. Mikolenko A. Administrative process and administrative responsibility in Ukraine: studies. Benefit. Kharkiv: Odyssey, 2006. 352 p.

20. Mironets I. Administrative and legal regulation of construction activity in Ukraine: dis. ... the candidate is legal. Sciences : 12.00.07. Kiev, 2012. $235 \mathrm{p}$.

21. Mironets N. Penalty liability for administrative offenses in construction activities. Lawyer. 2010. No. 6 (117). P. 34-38.

22. Nizankowska N. Administrative liability for offenses in the sphere of housing construction : abstract. dis. on the receipt Kazan. the degree 
candidate. Yuri. Sciences: spec. 12.00.14 "Administrative law; administrative process". Khabarovsk, 2011. $20 \mathrm{sec}$.

23. Parmenov S. Administrative responsibility in the construction industry. Republican construction newspaper. 2012. No. 39 (492).

24. Semenko B. administrative responsibility for offenses in the field of construction: dis. Cand. J. Sciences: spec. 12.00.07 "Administrative law and process; financial law; information law". Zaporozhye, 2011. $193 \mathrm{p}$.

25. Stukalenko O. Administrative responsibility for violation of norms of the land legislation (material and procedural aspect): dis. ... candidate of Jurid. Sciences: 12.00.07. Odessa, 2008. 181 p.

26. Tropina G. Legal nature of administrative responsibility in the field of construction. European perspective. 2013. No. 9. P. 79-86.

27. Harosak N. Administrative penalty according to the legislation of Ukraine: monograph. Kyiv: Institute of state and law. V. Koretsky NAS of Ukraine, 2004. 172 p.

28. About attraction to administrative responsibility for violation of the town-planning legislation. Comparative-analytical law. 2013. No. 4/1. P. 241-243.

29. Legal responsibility: problems of definition and dismissal.; TNA. ed. Donetsk: PE "VD "Kalmius", 2013. 424 p.

Information about the author: Nenko S. S.,

Candidate of Law, Associate Professor, Professor at the Department of Administrative,

Criminal Law and Procedure, International University of Business and Law 37-A, 49 HGD str., Kherson, 73040, Ukraine 


\section{ACTUAL PROBLEMS OF COVERT INVESTIGATION}

\section{Podobnyi O. O.}

\section{INTRODUCTION}

Covert investigative (detective) actions" (hereinafter - CI(D)A) in accordance with Art. 246 CCP is a type of CI(D)A, information about the fact and methods ${ }^{1}$ of conducting which are not subject to disclosure. Based on the stated legislative requirement, which prohibits detailed disclosure in the open source of the features of tactics, and especially technology, CI(D)A, the subject of this unit will become the general principles of the organization and tactics of their conduct.

CI(D)A shall be conducted in cases where the information about the crime and the person who committed it cannot be obtained otherwise, ie by conducting the I (D) A, as well as exclusively in criminal proceedings for serious or particularly serious crimes (except use of confidential cooperation and location of electronic means).

\section{General provisions for conducting Covert investigative (detective) actions}

The peculiarities of the actions provided for in Chapter 21 of the CCP and the introduction of the term "unspoken" on the one hand emphasize the differences from the "traditional" investigator's toolbox, such as CI(D)A, and, on the other, make it necessary to observe their implementation of such principle, which is elaborated by the theory of operative-search activity, as a conspiracy.

The principle of conspiracy to carry out the CI(D)A requires that the following three requirements be met: 1) the persons to whom they are committed should not be aware of these actions; 2) a similar approach to employees of investigative and operational units who are not organizers or executors of the $\mathrm{CI}(\mathrm{D}) \mathrm{A}$; 3) strict and steady securing of the regime of secrecy, as a special procedure for circulation of those documents and other material media of information, which are the property of the state and are protected by the Laws of Ukraine "On State Secret" and the CPC.

1 Про затвердження Інструкції про організацію проведення негласних слідчих (розшукових) дій та використання їх результатів у кримінальному провадженні: Наказ Генеральної прокуратури України, Міністерства внутрішніх справ України, Служби безпеки України, Державної прикордонної служби України, Міністерства фінансів України, Міністерства юстиції України від 16.11.2012 № 114/1042/516/1199/936/1687/5. 
Possibilities of a conspiratorial holding of the CI(D)A complex in the fOCGework of criminal proceedings, provided by the legislator in Art. 246, 253 of the CCP, which provide for a maximum term of such action in eighteen months and the moment of notification of the fact and the results of its conduct within twelve months from the date of termination of the action, but not later to appeal to the court with the indictment, - allow to establish the actual existence of criminal- the law institute of unspoken investigation as a special form of pre-trial investigation. Further development of the methodology for conducting such an investigation is an urgent task of forensic science.

The subjects of the CI(D)A are the investigator who carries out the pretrial investigation of the crime or, on his or her behalf, the authorized operational units.

Classification of $\mathrm{CI}(\mathrm{D}) \mathrm{A}$ is possible by many criteria: 1) procedural (actions related to interference with private communication and others; actions carried out exclusively in criminal proceedings for serious and particularly serious crimes and those carried out regOSAless of the gravity of the crime); 2) by an official who gives permission for their conduct (with the permission of the head of the pre-trial investigation body, the prosecutor, the investigating judge); 3 ) by the method, as a way of organizing the practical development of reality, which is the basis of the action (personal, technical); 4) by the authorized unit (person) - the direct executor of the working stage of the CI(D)A.

According to the last of these criteria, which in terms of forensics is the most relevant in covering the organizational and tactical aspects of the CI(D)A, it is advisable to highlight the actions that are carried out:

1) operational and technical units: 1.1) audio and video control of a person (Article 260 of the CPC); 1.2) removal of information from transport telecommunications networks (Article 263 of the CPC): 1.2.1) control over telephone conversations; 1.2.2) removal of information from communication channels; 1.3) removal of information from electronic information systems without the knowledge of its owner, owner or holder (Article 264 of the CPC); 1.4) establishment of the location of the electronic means (Article 268 of the CPC); 1.5) examination of publicly inaccessible places, housing or other possession (Article 267 of the CPC); 1.6) audio and video control of the place (Article 270 of the CPC);

2) operational units specializing in qualified visual observation observation of a person, thing or place (Article 269 of the CCP): 2.1) surveillance of a person in publicly accessible places; 2.2) observing the year or place in publicly accessible places; 
3) investigative or authorized operational units that are competent to organize the conduct of all CI(D)A: 3.1) removal of information from electronic information systems, access to which is not restricted by its owner, owner or holder or is not related to overcoming the logical protection system (Article 264 of the CCP); 3.2) unspoken receipt of samples required for comparative study (Article 274 of the CPC); 3.3) controlled and operational procurement; 3.4) controlled delivery; 3.5) a special investigative experiment; 3.6) simulating the situation of the crime; 3.7) arresting correspondence (Article 261 of the CPC); 3.8) review and withdrawal of correspondence (Article 262 of the CPC); 3.9) monitoring of bank accounts;

4) covert employees: 4.1) performing a specific task of disclosing criminal activity of an organized group or criminal organization (Article 272 of the CPC); 4.2) the use of confidential cooperation (Article 275 of the CPC).

At the organizational and tactical level, any CI(D)Ais carried out in three stages: 1) preparatory (organization and planning); 2) working (direct); 3 ) final (recording and documenting the results).

The criminal procedural legislation in a general form defines the content of both the preparatory and the final stages of the CI(D)A. At the same time, the tactics, and especially the technology, of the working stage of the CI(D)Ais directly the prerogative of methodological recommendations developed by forensic science and theory of operative-investigative activity on the basis of practice materials, formalized at the level of instructions with the restriction of access of bodies, within which there are authorized operational units.

At the preparatory stage, first of all, a decision is made to hold the $\mathrm{CI}(\mathrm{D}) \mathrm{A}$. This is the responsibility of the investigator, the prosecutor, and in the cases provided for by the CPC, the investigating judge at the request of the prosecutor or at the request of the investigator, agreed with the prosecutor.

The resolution of the investigator, the prosecutor on the conduct of the CI(D)A must contain: 1) the name of the criminal proceedings and his registration number; 2) the legal qualification of the crime, indicating the article (part of the article) of the CCP; 3 ) information about the person (s), place or thing in respect of which the $\mathrm{CI}(\mathrm{D}) \mathrm{A}$ will be conducted; 4) the beginning, duration and purpose of the CI(D)A; 5) information about the person (s) who will conduct the CI(D)A; 6) substantiation of the adopted resolution; 7) an indication of the type of emergency I(D) A being conducted. 
If an investigating judge makes a decision on the conduct of a particular $\mathrm{CI}(\mathrm{D}) \mathrm{A}$, as required by the $\mathrm{CCP}$, he or she is required to consider the request within six hours of receiving it. The petition is considered with the participation of the person submitting the petition.

The petition shall state: 1 ) the name of the criminal proceedings and its registration number; 2) a summary of the circumstances of the crime in connection with which the request is being investigated; 3) legal qualification of the crime, with an indication of the article (part of the article) of the Criminal Code of Ukraine (hereinafter - the Criminal Code); 4) information about the person (s), place or thing, for which it is necessary to carry out $\mathrm{CI}(\mathrm{D}) \mathrm{A} ; 5)$ circumstances giving grounds to suspect a person of committing a crime; 6) type of $\mathrm{CI}(\mathrm{D}) \mathrm{A}$ and justification of the term of its holding; 7) justification of the inability to obtain information about the crime and the person who committed it in another way; 8) information, depending on the type of $\mathrm{CI}(\mathrm{D}) \mathrm{A}$, about identification features that will allow uniquely identifying the subscriber of the surveillance, telecommunication network, terminal equipment, etc.; 9) substantiation of the possibility of obtaining, during the $\mathrm{CI}(\mathrm{D}) \mathrm{A}$, evidence which alone or in combination with other evidence may be of significant importance for clarifying the circumstances of the crime or identifying the perpetrators.

An excerpt from the Unified Register of Pre-trial Investigations on Criminal Proceedings under which the motion is filed shall be attached to the request of the investigator, the prosecutor.

The decision of the investigating judge on the permission to hold the CI(D)A must contain information about: 1) the prosecutor, the investigator who applied for the petition; 2) a crime in connection with which a pre-trial decision is ruled; 3 ) the person (s), place or thing in respect of which it is necessary to carry out the CI(D)A; 4) type of CI(D)A and information on identification features that will allow uniquely identifying the subscriber of the surveillance, telecommunication network, terminal equipment, etc.; 5) the validity period of the decision.

The latter may not exceed two months. Where necessary, the term of the CI(D)A may be extended in accordance with the requirements of the legislation.

In exceptional cases of urgency relating to the saving of human life and the prevention of the commission of a serious or particularly grave crime provided for in Sections I, II, VI, VII (Articles 201 and 209), IX, XIII, XIV, XV, XVII of the Special Part of the Criminal Code, The CI(D)A may be initiated pending the decision of the investigating judge in the cases provided for by the $\mathrm{CCP}$, at the discretion of the investigator agreed with the prosecutor or the prosecutor. In such a case, the prosecutor is obliged to 
immediately apply to the investigating judge immediately after the start of such CI(D)A.

The investigator, the prosecutor, sends the instruction to the head of the body, which includes operational units, authorized to conduct the CI(D)A. In the case where the materials of the investigative activity were used as a pretext and basis for the initiation of a pre-trial investigation, a warrant for the execution of the $\mathrm{CI}(\mathrm{D}) \mathrm{A}$ is usually given to the operative unit that detected the crime, but its powers are taken into account. Prior to the order of the investigator, the prosecutor shall be accompanied by the decision of the investigating judge on the permission to hold the $\mathrm{CI}(\mathrm{D}) \mathrm{A}$ or the decision of the investigating prosecutor to hold the CI(D)A. The authorized operational unit for the execution of the order of the investigator, the prosecutor, taking into account the need to ensure the conditions for the execution of the CI(D)A, shall, on the basis of its task, involve the relevant operational and operational-technical units.

The criminal procedural legislation provides that at the final stage there is a fixing and documenting of the results of the CI(D)A. In accordance with the requirements of the CCP on the results of the $\mathrm{CI}(\mathrm{D}) \mathrm{A}$, a protocol is drawn up, which, if necessary, shall be accompanied by annexes (specially made copies, samples of objects, things and documents, written explanations of the specialists who participated in the respective action, a transcript, audio, video, photo tables, schematics, casts, computer media, and other materials explaining the content of the protocol).

Information on persons who conducted or were involved in the CI(D)A may, in the case of security measures, be provided with the confidentiality of such persons in accordance with the procedure established by law. The conduct of CI(D)A can be fixed by technical and other means.

CI(D)A the use of technical means, items removed during the process and documents or copies thereof may be used in proving on the same grounds as the results other I(D)A during the pre-trial investigation.

The frequency of drawing up protocols depends on the type of CI(D)A, its duration (at one time or over time), on the instructions of the investigator, the prosecutor, but in any case immediately after obtaining factual data that can be used as evidence to establish the whereabouts of the person. wanted case by case, review, recess, investigation of the results of the fraudulent investigative action, etc.

According to the results of the order of the investigator, the operative employee makes a report indicating the results of the executed order, the forces and means involved, as well as their results. The head of the authorized operational unit makes the decision by imposing a resolution on the report regOSAing the possibility of sending the protocol and its 
attachments to the prosecutor or taking measures for the proper execution of the order. The report and its annexes shall be submitted to the prosecutor indicated in the warrant no later than twenty-four hours after the termination of the CI(D)A. Materials that can decrypt individuals who are sources of information on a confidential basis are not provided.

The prosecutor or investigator, at his or her instruction, investigates information received during the course of the CI(D)A. If necessary, a specialist is involved.

Persons who have or have been involved in the CI(D)A may be questioned as witnesses. The interrogation of these persons may be conducted with the secrecy of the information about these persons and with the application of the relevant security measures prescribed by law.

When used to prove the results of the CI(D)A, the persons whose actions or contacts were carried out may be questioned.

The Prosecutor shall take measures to preserve the documents and documents he / she intends to use during criminal proceedings. It is not allowed to make copies of protocols on carrying out the CI(D)A and its annexes.

The Instruction provides for the procedure for the classification and declassification of material storage media for the conduct of the CI(D)A.

Very important, both theoretically and especially, in practical terms, is the problem of realization of materials of operative development (silent investigation), since this process involves the transition from carrying out silent investigative (investigative) actions to investigative (investigative) actions of a vowel character.

The issue of the implementation of materials for operational development, as one of the central in the theory of OSA, has constantly attracted the attention of scientists. This problem was investigated by V. M. Atmazhitov, Yu. I. Veselov, G. O. Dusheiko, A. O. Mikhailichenko, M. B. Sahakyan, V. G. Samoilov and others ${ }^{2}$. The practice of operational units and the theory of OSA strongly suggests that the complexity of this stage of work on organized crime causes the need for organizational and tactical solution of the issue in the form of surgery. In their turn, A. V. Dulov, L. Ya. Drapkin, V. I. Shikanov and others ${ }^{3}$, concerning the

${ }^{2}$ Атмажитов В. М. Требования, предъявляемые к реализации оперативно-розыскной информации. Межвузовский сборник научных трудов. Омск: ВШ МВД СССР, 1985. С. 70-73; Душейко Г. О. Організаційно-тактичні основи реалізації оперативнорозшукової інформації в стадії порушення кримінальної справи : дис. ...канд. юрид. наук : 12.00.09. Харків, 2000. $271 \mathrm{c}$.

Дулов А. В. Тактические операции при расследовании преступлений. Минск: Вышейша школа, 1979. 128 с. 
problems of conducting tactical operations in the investigation of crimes in their investigations, understood under such operations the system of investigative actions, tactical techniques, OSA, organizational and other actions developed and carried out in the course of a single-plan investigation under the overall direction of the investigator in order to accomplish such a tactical task as cannot be resolved by the individual investigative action. At the same time, the investigative operation was defined by researchers as the highest organizational element of the OSA, a system of coordinated and interconnected purpose, time, location of the OSA and actions carried out on a separate plan from a single center aimed at achieving the purpose and fulfillment of the tasks of the OSA envisaged. legislation.

Thus, the implementation of operational development materials can be defined as a system of coordinated procedural actions and OSA, which allow the use in the process of investigation of data obtained in a tacit manner, with the aim of successful prevention, investigation of crimes and exposing criminals, as well as the search of persons who are hiding from an investigation, trial or serving a criminal sentence. In most cases, the implementation coincides with the start of the investigation. In this case, the investigator and the employees of the operational units solve the sole task the investigation of the identified crime (criminal activity). That is, the implementation of materials for operational development involves the implementation of a variety of OSA, CI(D)A and I(D)A, which complete the preliminary process of silent documentation of organized criminal activity, and provide the opportunity to use the materials of OSA (covert investigation) in the criminal process.

In connection with the adoption of the CCP of Ukraine in 2012.7 of the Law on OSAs "Duties of units that carry out OSAs" was supplemented by paragraphs 2-4 of the following content: " 2 . In case of detecting signs of a crime, the operational unit carrying out the OSA is obliged to immediately send the collected materials, which record the factual data about the illegal actions of individuals and groups, responsible for which are provided by the Criminal Code of Ukraine, to the appropriate body of pre-trial investigation for initiation and conduct of pre-trial investigation in the manner provided by the CPC of Ukraine. 3. If the signs of a crime are detected during a continuing ORD and termination of which may adversely affect the outcome of the criminal proceedings, the unit conducting the OSA shall notify the relevant pre-trial investigation authority and the prosecutor of the detection of the signs of the crime and finish the operational search event (allocated by us - OO), after which sends the collected materials, which record the actual data on the illegal actions of individuals and groups, the responsibility for which is provided by the Criminal Code of Ukraine, to the relevant Ghana 
preliminary investigation. "This version of Part 3 of Art. 7 of the Law "On OSA", from our point of view, needs refinement by replacing the phrase "ends the search and search event" by the same words in the plural, because within the implementation of materials for operational development ends the complex of operational search operations.

Part four of Art. 7 of the Law "On OSA" according to subparagraph 5 of paragraph 12 of the said law provides the procedure according to which the operational units spend I(D)A and CI(D)A in criminal proceedings on the instructions of the investigator, prosecutor in the manner provided by the CPC of Ukraine. Written instructions for conducting I(D)A and CI(D)A submitted to investigators, prosecutors within the competence and in due course are obligatory for execution of operational units.

Thus, these normative novelties, both legislative and departmental, that initiated the corresponding practice, allow us to raise in scientific terms the question of the theoretical concept of the unity of operative development and silent investigation of self-employed and organized crime.

\section{Operational and investigative support of criminal proceedings}

Investigation of crimes, especially those perpetrated by organized criminal groups (hereinafter referred to as OCG), is carried out through the integrated use of forces, means and methods of operative-investigative and criminalprocedural activity. Therefore, in the legal literature the issue of interaction of the investigator with the employees of the operational units has received considerable attention. From the standpoint of criminal proceedings and forensics, it was investigated by V. D. Bernaz, R. S. Belkin, G. Yu. Bondar, A. F. Volobuyev, L. Ya. Gordin, A. V. Dulov, G. G. Zuikov, V. P. Lavrov, I. V. Leshukova, I. M. Luzgin, S. V. Murashov, M. A. Pogoretsky, O. V. Starchenko and other scientists ${ }^{4}$. The issue of interaction of operational units with investigators in the fight against crime was also given considerable attention in the theory of OSA by V. M. Atmazhitov, O. M. Bandurka, M. P. Vodko, D. V. Grebelsky, V. L. Groholsky,

${ }^{4}$ Берназ П. В. Взаємодія слідчого з оперуповноваженим ДСБЕЗ при розслідуванні економічних злочинів : дис. ...кандидата юрид. наук: 12.00.09. Одеса, 2006. 200 с.; Білоус В. Т. Координація управління правоохоронними органами України по боротьбі 3 економічною злочинністю (адміністративно-правовий аспект) : дис. ...доктора юрид. наук: 12.00.07. Ірпінь, 2004. 444 с.; Бондар Г. Ю. Правове забезпечення взаємодії слідчих правоохоронних відомств у кримінальному судочинстві України : дис. ...кандидата юрид. наук: 12.00.09. Харків, 2004. 230 с.; Волобуєв А. Ф. Взаємодія слідчого з оперативними підрозділами при розслідуванні економічних злочинів. Форум права. 2006. № 1. URL: http://www.nbuv.gov.ua/e-journals/FP/2006-1/06vafrez.pdf. 
A. F. Dolzhenkov, K. K. Ermakov, I. O. Klimov, I. P. Kozachenko, M. V. Kornienko, A. G. Markushin, V. P. Khomkolov and others ${ }^{5}$.

Some scientists determine the operative-search support of the investigator's activity by a complex of legal and organizational-tactical measures that determine the interrelation and interaction of the investigative and operational units of the police department with the aim of a comprehensive, complete and objective study of the circumstances of the case, others by a complex of operational-search activities. carried out by the relevant OIA operational services to ascertain the sources and sources of information that are inherent in the methods and means of evidence to be proven in criminal proceedings for the purpose of obtaining investigative data that facilitate the establishment of truth and the taking of guilty measures provided for by law, the third - the activity of operational units to create optimal conditions for full and objective investigation, by carrying out a complex of OSA, mostly intelligence in nature, against persons who are held criminally liable, their relationships and other persons involved in the crimes being investigated, as well as neutralize their unlawful influence on procedural evidence ${ }^{6}$. Considering these definitions as a basis, we consider it necessary to clarify a number of significant points in the light of recent legislative developments.

As historically OSA was one of the means of criminal procedural cognition that enhances the latter's cognitive capabilities ${ }^{7}$, we finally witnessed this recognition when the CCP of Ukraine adopted this function in 2012 when investigative activities actually became part of criminal proceedings in criminal proceedings. the proceedings for which the pre-trial

${ }^{5}$ Гребельский Д. В. Теоретические основы и организационно-правовые проблемы оперативно-розыскной деятельности органов внутренних дел. Москва: Акад. МВД СССР, 1977. 171 с.; Грохольський В.Л. Управління діяльністю спеціальних підрозділів МВС України по боротьбі з організованою злочинністю : дис. ... доктора юрид. наук : 12.00.07. Харків, 2004. 416 с.; Водько Н. П. Организация комплексной борьбы с рецидивной преступностью. (На материалах оперативных аппаратов милиции и исправительнотрудовых учреждений). К.: РИО МВД УССР, 1981. 160 с.

${ }^{6}$ Хомколов В. П. Правовые и организационно-тактические вопросы оперативнорозыскного обеспечения деятельности следователя по установлению лица, совершившего преступление : дис. ... кандидата юрид. наук: 12.00.09. Москва, 1984. С. 13.

Бордиловский Э. П. Сущность и основные направления оперативно-розыскного обеспечения предварительного расследования групповых преступлений. Труды Академии МВД СССР. Москва: Академия МВД СССР, 1990. С. 109-115.

Рябков Е. М. Правовые, организационные и тактические вопросы оперативнорозыскного обеспечения предварительного следствия по преступлениям, совершенным группой лиц : дис. ... канд. юрид. наук. Москва, 1990. С. 20.

${ }^{7}$ Погорецький М. А. Функціональне призначення оперативно-розшукової діяльності у кримінальному процесі : монографія. Харків: Арсіс, ЛТД, 2007. С. 269-270. 
investigation was initiated. This situation, in our view, does not negate the importance of operational and investigative support of criminal justice, but on the contrary raises it to a new level, since neither the investigator nor the prosecutor, obviously, will be able to conduct any of the Criminal Code of Ukraine provided for by the Criminal Procedure Code. Without going into the discussion about the correlation between the concepts of "disclosure" and "investigation" of crimes, we emphasize that OSA and criminal procedural activity are equally in accordance with Art. 2 The CPC of Ukraine implements the requirement of legislation to ensure prompt full and impartial investigation and trial. In this connection, the Ministry of Internal Affairs of Ukraine in most of the policy documents constantly emphasizes the need to increase the role and responsibility of each National Police service in the investigation of crimes, to use all its resources and resources for this purpose ${ }^{8}$.

The term "operative-investigative support of the investigation" was first formulated in the Instruction of the Ministry of Internal Affairs of the USSR of 05.12.1984 and in subsequent normative acts of the Ministry of Internal Affairs of the USSR, which emphasized the need for operationalinvestigative support of the preliminary investigation. In the directive documents of the Ministry of Internal Affairs of Ukraine, this line of activity was named "operative-investigative support of criminal proceedings" 9 and formulated as a complex of operative-investigative measures in the interests of specific criminal proceedings in order to search and record the factual data that can be evidence in this case, to ensure complete and complete and effective investigation of the circumstances of the case, the safety of the participants in criminal proceedings, the constant informing of the bodies of pre-trial investigation and the court about the actions of the suspect $\mathrm{x}$, accused and other persons, aimed at adversely affecting the participants in criminal proceedings to counteract the establishment of truth in the case. Moreover, the term "operational support for pre-trial investigation" is also

8 Про затвердження Інструкції 3 організації взаємодії органів досудового розслідування з іншими органами та підрозділами внутрішніх справ у попередженні, виявленні та розслідуванні кримінальних правопорушень: Наказ МВС України від 14.08.2012 № 700; Про організацію реагування на повідомлення про кримінальні правопорушення, інші правопорушення, надзвичайні ситуації та інші події, та забезпечення оперативного інформування в органах і підрозділах внутрішніх справ України: Наказ МВС України від 22.10.2012 № 940.

${ }^{9}$ Про організацію діяльності Департаменту карного розшуку та підрозділів карного розшуку ГУМВС, УМВС: Наказ МВС України від 30.06.2009 № 285 [Втратив чинність]; Про затвердження Положення про Департамент карного розшуку Національної поліції України : Наказ Національної поліції України від 14.11.2015 року № 90. URL: https://www.npu.gov.ua/uk/publish/article/1813212 
used in the instructions of the Ministry of Internal Affairs of Ukraine, approved after the entry into force of the CCP $2012^{10}$.

Consistent with the substantive workload of the above definition, we cannot unequivocally accept the application of that term. Its use is not entirely justified even from the etymological point of view, since the accompaniment emphasizes only parallelism, concurrency of certain actions. Although this feature is present in the phenomenon we are investigating, its essence is mostly revealed by its active form, such as to provide or "provide material means, protect against danger, guarantee". This understanding is also borne out by the legal meaning of the term "security", in particular as regOSAs civil action or contractual obligations.

The participation of the operational units in the initiated proceedings, although carried out in accordance with Art. 41 of the CPC of Ukraine (2012), within the written mandate of the investigator, the prosecutor, however, it is not limited to the activity of procedural consolidation of factual data on the involvement of specific persons in criminal activity. Operational-search support cannot be reduced to the passive function of its support or the qualified execution of individual CI(D)A, but must be of an active security nature. According to paragraph 6 of Art. 7 of the OSA Law, operational units, in particular, are obliged to ensure, with the involvement of other units, the safety of court staff and law enforcement, assisting persons, facilitating search and search activities, are involved in criminal proceedings, their families and close relatives of these individuals. Full absorption of the operative-search function by the criminal-procedural objective cannot take place in view of its broader tasks beyond the scope of the judiciary, the presence in the structure of the OSA of other organizational-such forms: operative search (criminal intelligence) and prompt development with mandatory requirements. their offensiveness, continuity and cyclicity.

We can offer the following scientific definition of a research institute of OSA theory: operative-investigative support of criminal proceedings is a system of measures, mostly of a non-silent nature, qualified by operational units under the direction of the investigator and the prosecutor at the stages of pre-trial investigation and judicial review in order to create optimal investigations process of investigation, termination or neutralization of counteraction of participants of organized criminal group to law enforcement the equal function of the state and justice, ensuring the safety of participants in criminal proceedings.

10 Про затвердження Інструкції 3 організації взаємодії органів досудового розслідування з іншими органами та підрозділами внутрішніх справ у попередженні, виявленні та розслідуванні кримінальних правопорушень: Наказ МВС України від 14.08.2012 № 700 . 
The creation of optimal conditions for a full and objective investigation process begins at the early stages of detecting signs of crime, directly implemented within the fOCGework of the operational and investigative function of combating crime through the implementation of a complex of document the criminal activities of persons under development in the work of the established OSA. As noted earlier, documentation of its purpose and content solves problems that coincide with the institution of criminal procedural evidence, creates optimal conditions for its subsequent implementation after deciding to start a pre-trial investigation. The effectiveness and efficiency of criminal procedural evidence depends to a great extent on the completeness and reliability of the documentation. Realizing the requirements of the Law on OSAs and the CPC of Ukraine, documentation, as an organizational form of complex application of OSAs, ensures that an informed decision is made to implement the materials obtained through it through the initiation of a pre-trial investigation. It is from this moment that the stage of operative-investigative provision of procedural evidence in criminal proceedings concerning organized criminal groups (hereinafter referred to as OCG) begins.

In most cases, the moment of initiation of an investigation is related to the situation when the law enforcement authorities have established the fact of committing a specific acts of self-violence, but have not identified the person (s) who committed the crime. Prior to the adoption of the CPC of Ukraine in 2012, it was the operational units that were obliged to install such persons, working on a "crime-to-person-perpetrator" scheme. According to the current legislation, the task of identifying persons who have committed a specific organized crime is solved by conducting, on the instructions of the investigator or prosecutor, the $\mathrm{CI}(\mathrm{D}) \mathrm{A}$ by specialized operational units. Through these actions, operational units also solve the task of determining the location of the suspect, other persons involved in the crime, or who became his victim, the search for stolen objects, valuables, tools and means of committing the crime.

After establishing the event and the composition of the crime, the perpetrators of it, in order to solve the problems of timely and complete proof of the guilt of each of its participants, the degree of their organization, weapons, etc., is crucial to make such responsible procedural decisions in accordance with the rules of the CPC of Ukraine, as: notification of suspicion (Articles 276-279); identification of suspected preventive measures (Chapter 18); complex of urgent investigative (investigative) and emergency I(D)A in order to consolidate the available and to find additional evidence. The specific investigative situation at this stage requires the operational units to create optimal conditions for the execution of 
appropriate procedural decisions and actions. Therefore, there is a need for the planning and simultaneous implementation of many different abusive investigators (investigative) and $\mathrm{CI}(\mathrm{D}) \mathrm{A}$. In order to accomplish this task, investigative teams (hereinafter referred to as "IT") are set up in most cases in the course of an investigation into organized crime.

Many of the researchers who conducted investigations into the organization of crime investigations expressed the need to enshrine in the criminal procedural law the specified form of interaction of investigative and operational units under the name of the investigative-operational group. At the same time, the CPC of Ukraine, in three different articles, provides for the possibility of a group organization to investigate crimes. Particularly in Part 2 of Art. 38 states that pre-trial investigations are carried out by investigators of the pre-trial investigation body alone or by an investigative team. As well as Part 1 of Art. 37 establishes a provision according to which, if necessary, the head of the prosecutor's office may designate a group of prosecutors to exercise the powers of the prosecutor in a particular criminal proceeding, as well as a senior prosecutor of a group that will oversee the actions of other prosecutors. Article 571 "Creation and Operation of Joint Investigation Teams" sets out specific mechanisms for international cooperation.

It should be emphasized that the vast majority of criminal proceedings for organized criminal activity are carried out by the group method, that is, for the purpose of the qualified implementation of the $\mathrm{CI}(\mathrm{D}) \mathrm{A}$, the employees of the operational units are involved. This is how the operativeinvestigative support of the investigation of the criminal activity of a particular OCG happens. And, as we mentioned above, according to Part 2 of Art. 41 of the CPC of Ukraine, employees of operational units in the performance of investigator's orders, including in the work of the work of the IT, use the powers of the investigator.

Studying the practice of investigating organized crime has made it possible to formulate a number of proposals for its structural and functional improvement. Based on the specifics of working in criminal investigations on crimes of the investigated category, which is to ensure strict observance of the principles of confidentiality, prevention of information leakage, an important aspect of organizing the work of the group we see the issue of dividing the members of the IT into three levels of awareness of the circumstances of the investigated organized activities investigations (levels of access to information). These levels of access are also created to counteract intelligence activities as a means of counteracting the pre-trial investigation being undertaken by OCG members and their connections at large. 
The highest level of access to information, that is, the entire range of IT activities, should be enjoyed by those involved in the work of the Group Headquarters. The headquarters of the IT must include: Senior Investigative Team in accordance with paragraph 1 of Part 2 of Art. 39 of the CPC of Ukraine; the leader of the operational wing of the group (usually at the level of the leader or deputy leader of the relevant operational unit); the most experienced employees of the operational units. In accordance with the requirements of Part 1 of Art. 37 of the CPC of Ukraine is objective that the IT staff should include a prosecutor or a group of prosecutors with a senior prosecutor of such a group. According to the provisions of the CPC of Ukraine, a prosecutor or a group of prosecutors within the IT staff, in the function of supervising the observance of laws during the pre-trial investigation, exercise procedural guidance over them. They undoubtedly have greater powers than the formal SG supervisor - investigator (see Part 2 of Article 36 of the CCP). This is a significant problem, the solution of which remains the task of science, law enforcement and the legislature. At the same time, it is undesirable to exceed the total number of persons involved in the work of the staff, 6-7 employees, but, nevertheless, in each case the composition of the HQ staff is determined by its head, based on the specific circumstances of criminal proceedings, the degree of its complexity and the number of episodes under investigation.

The next level of awareness of the circumstances of the crime and the measures taken to disclose it, should be owned by persons involved in working in a subgroup to work out specific case information or individual versions. The IT leader should dispense information provided to employees involved in the work of this subgroup, to the extent necessary for the qualitative completion of specific tasks and completion of individual versions provided for in the work plan. This subgroup includes investigators who are recruited by the SG supervisor through the adoption of a relevant resolution, as well as members of operational units. As a rule, the total membership of this group should not exceed 10 people. In the event that there is a need to expand the group of members during the development of additional versions or after the perpetrators have been established, the composition of this group may be expanded by issuing an additional resolution of the investigator to change the composition of the IT.

Specialized Rapid Response Officers of the KORD, the patrol police involved in the work of the IT, form a group of assigned forces. This group has the least awareness of the circumstances of the crime and the measures being taken in its investigations. These employees are directly involved in conducting tactical operations according to the plans developed, assist in the conduct of individual investigative (search) 
actions, exercise physical protection of the participants of criminal proceedings and act on the basis of information provided to them by the IT management during careful briefing.

As a separate direction of creating optimal conditions for a complete and objective investigation process in the work of the operative and investigative support of organized criminal proceedings, it is necessary to recognize the provision of practical implementation of the use of confidential cooperation as the CI(D)A, provided for in Art. $275 \mathrm{CPC}$ of Ukraine. Pursuant to Part 1 of the said Article, the investigator has the right to use the information obtained as a result of confidential cooperation with other persons, or to involve them in the conduct of the CI(D)A. At the same time, the answer but up to item 13 of Art. 8 of the Law on OSA, which provides for the right of operational units, in particular, to have non-public staff and freelance employees, the subject of establishing and direct implementation of such confidential cooperation is an employee of the operational unit.

The use of confidential cooperation is most effective at the initial stage of the investigation in the form of prompt detention of detainees. The psychological situation of their isolation from the accomplices and habitual social environment, which causes the natural necessity of communication, allows to obtain, by means of expedited working out, the actual factual data. The advantages of this form of operational investigative support for the investigation of OSA are that the information obtained in compliance with the rules of conspiracy can be immediately involved in the process of proving by conducting investigative (investigative) and $\mathrm{CI}(\mathrm{D}) \mathrm{A}$. This ensures that the principles of completeness and objectivity are proven. Unfortunately, the aforementioned possibilities are not used to full capacity, as at the stage of judicial review the operational work is mostly unreasonably terminated, and the prospecting work at the stage of court proceedings is generally used in exceptional cases by court decision. This issue remains unregulated.

The cessation or neutralization of the opposition of the members of the OSA to the enforcement of the law-enforcement function of the state and justice is one of the important areas of operational and search support, which has received much more attention ${ }^{11}$.

11 Александренко О. В. Криміналістичні проблеми подолання протидії розслідуванню: дис. ...канд. юрид. наук : 12.00.09. Київ, 2003. 183 с.; Карагодин В. Н. Преодоление противодействия предварительному расследованию. Свердловск: Изд-во Уральского ун-та, 1992. 247 с. 
The analysis of these publications and the materials of our own research showed that the means of counteraction to the criminal environment are many, and their tactics are quite diverse. Therefore, it is impossible to limit yourself to one, though very effective, method of overcoming such opposition. It is established that OCG, taking countermeasures, mainly operates in two directions: blocking agent penetration into their environment (13\%), as well as finding sources of leakage of information on operational development, plans of investigation and planned operative-search (tactical) operations (12\%). In the hierarchy of specific criminal acts, the following measures are identified: detection, bribery, intimidation and other influence on the victims and witnesses in order to persuade them to give "necessary" grouping of testimonies $(10 \%)$; making maximum use of the imperfections of the current system of detention in penitentiary institutions for the purpose of establishing illegal channels of communication with arrested participants of the OCG and coordinating counter-measures $(9 \%)$; hiring high-quality attorneys for the means of "obshak", creating advocacy groups for the investigators $(9 \%)$ concealing suspects outside Ukraine and providing them with false documents $(10 \%)$; destruction of traces of weapons and means of criminal activity (10\%); simulation of diseases (1\%); pressure through the media (5\%); deliberate discrediting of operatives, investigators, prosecutors, investigating judges and judges, including through defamation contained in complaints and statements (2\%); the use of corrupt communications, as well as bribery of investigators, prosecutors, officers of the operative units, investigative judges, judges (10\%); Attempt to recruit the said parties to the prosecution on the side of the prosecution on material (9\%) and so on.

At the same time, the researchers discuss the tactics of counteraction of the OCG to law enforcement agencies by grouping specific actions, which are divided into the following blocks of measures: 1) a block of measures that organize criminal activity; 2) a block of measures aimed at ensuring the technical superiority of OCG over law enforcement agencies; 3) a block of measures to ensure the concealment of criminal activity; 4) actions aimed at creating an effective system of contacts in the structures of the authorities to ensure the guaranteed protection of their interests and the safety of the members of the group; 5) actions aimed at protecting economic and political power in the regions; 6) forceful pressure on the part of the society in which respect for law and order was formed, on the authorities, whose functions include the protection of the rights and freedoms of citizens ${ }^{12}$.

12 Теория оперативно-розыскной деятельности : учебник / [ под ред. К. К. Горяинова, В. С. Овчинского, Г. К. Синилова ]. Москва: ИНФРА-М, 2008. С. 497-500. 


\section{CONCLUSIONS}

From the mentioned measures of counteraction of the OCG to the accomplishment of the tasks of criminal justice, it can be concluded that the operative-search support of the latter requires the qualified application of the system of the CI(D)A.

In order to stop or neutralize the counteraction of the criminal environment at the stages of pre-trial investigation or trial, it is advisable to use: 1) the performance of a special task for the disclosure of criminal activities of $\mathrm{CO}$ or the $\mathrm{CC}$ (Article $272 \mathrm{CCP}$ ); 2) the use of confidential cooperation (Article 275 of the CCP); 3) conducting surveillance of a person, thing or place (Article 269 of the CCP) in the environment of participants in criminal proceedings, their official or domestic environment, as well as active visitors to court hearings; 4 ) in the presence of appropriate grounds, the use of operational and technical means of control of the actions developed and documentation of their illegal activities. Aggregate The findings of factual findings and methods of counteracting the investigation or trial so identified may, at the discretion of the investigator, prosecutor or judge, be directly annexed to the criminal proceedings concerning organized crime. Evidence obtained, depending on the nature and form of the counteraction, may be the basis for deciding whether to bring the perpetrators to administrative or criminal liability. The timeliness of the implementation of the $\mathrm{CI}(\mathrm{D}) \mathrm{A}$ to identify, document the facts of counteraction to the criminal environment creates favorable conditions for an objective and complete pre-trial investigation and trial of organized criminal activity.

\section{SUMMARY}

In the article it is proved that the following basic tasks are solved during the operative development and silent investigation: prevention or cessation of serious or especially serious crimes, which are being prepared; establishment of all members of the group, functions of each; documentation of specific facts (episodes) of criminal acts; preventing the possibility of those who are being developed to evade the investigation and the court, to counteract the establishment of the truth, to ensure the safety of the participants of the operative-investigative activity, the criminal proceedings, the employees of the court and the law-enforcement bodies, their relatives. Other tasks include: identifying ways to engage new members, corrupt relationships, creating your own security system and organizing counteraction to the law enforcement system; establishment of the fact of existence of general funds of the group, system of distribution of criminal incomes, their legalization; 
ensuring compensation for material losses caused by the actions of the developed and their accomplices; detention of wanted criminals; identifying and eliminating conditions conducive to crime.

It is determined that the ways of achieving the outlined tasks in the new procedural conditions are: introduction at the departmental level of the possibility of gradual implementation of special units of operational developments of criminal organizations by bringing to responsibility both individual developed and organized groups, which are structural parts of such groups; use of tools of silent investigation with simultaneous or parallel conducting of operational development of other structural units of the detected criminal group.

It is proposed to determine the operative-search support of criminal proceedings as a system of measures, mostly of a vague nature, carried out by operational units under the direction of the investigator and the prosecutor at the stages of pre-trial investigation and trial in order to create optimal conditions for a full and objective process of investigation, termination or neutralization of participants criminal group for the performance of the law enforcement function of the state and justice, ensuring the safety of Crimean participants legal proceedings.

\section{REFERENCES}

1. Александренко О. В. Криміналістичні проблеми подолання протидії розслідуванню: дис. ...канд. юрид. наук : 12.00.09. Київ, 2003. $183 \mathrm{c}$.

2. Бордиловский Э. П. Сущность и основные направления оперативно-розыскного обеспечения предварительного расследования групповых преступлений. Труды Академии МВД СССР. Москва: Академия МВД СССР, 1990. С. 109-115.

3. Карагодин В.Н. Преодоление противодействия предварительному расследованию. Свердловск: Изд-во Уральского ун-та, 1992. $247 \mathrm{c}$.

4. Погорецький М. А. Функціональне призначення оперативнорозшукової діяльності у кримінальному процесі : монографія. Харків: Арсіс, ЛТД, 2007. 576 с.

5. Рябков Е. М. Правовые, организационные и тактические вопросы оперативно-розыскного обеспечения предварительного следствия по преступлениям, совершенным группой лиц : дис. ... канд. юрид. наук. Москва, 1990. 200 с.

6. Теория оперативно-розыскной деятельности : учебник / [под ред. К. К. Горяинова, В. С. Овчинского, Г. К. Синилова]. Москва: ИНФРА-М, 2008. 832 с. 
7. Хомколов В.П. Правовые и организационно-тактические вопросы оперативно-розыскного обеспечения деятельности следователя по установлению лица, совершившего преступление : дис. ... кандидата юрид. наук: 12.00.09. Москва, 1984. 200 с.

Information about the author: Podobnyi O. O., Doctor of Laws, Professor, Head of the Department of Criminal Law, Process and Criminalistics, International Humanities University 33, Fontanska Road str., Odessa, 65009, Ukraine 


\section{THE GENESIS OF ADMINISTRATIVE OFFENCES}

\section{Popovich Ye. M.}

\section{INTRODUCTION}

Today's public consciousness regarding the concept of an administrative offense (misdemeanor) reflects its understanding of the stereotype that developed in Soviet times. Sociological studies conducted on this issue in 2010-2013 showed that employees of administrative services of internal Affairs bodies of district and city levels almost one hundred percent ( $96.75 \%$ of 1765 respondents) pointed to them as identical concepts, which are normative, fixed CAO Ukraine.

Meanwhile, in the works of a number of experts, which in varying degrees concerned the issues of the essence and content of the phenomenon with the modern name "administrative offence (offense)" we find indications for a certain inconsistency of the official Soviet doctrine of administrative offences: first, research lawyers of the Russian Empire XIX early XX centuries, and secondly, with the European administrative-legal theory and practice, third, research of the subject of administrative law and administrative legal relations in the last third of the twentieth and early twenty-first century.

Overcoming the actually existing scientific and theoretical crisis in this segment of administrative law, according to V. Kolpakov, should begin with the deepening of scientific understanding of the administrative offense and administrative offense as genetically different legal categories with the subsequent formation, firstly, the doctrine of administrative (administrative) offense; secondly, the doctrine of administrative misconduct (tort) ${ }^{1}$.

\section{Historical and legal nature of an administrative offense (misdemeanor)}

The formation of the Institute of administrative (administrative) offense with determinant features of the legal category is inextricably linked with the emergence of administrative law and administrative proceedings (administrative justice). Explain why. Purely schematic. Practice of functioning of administrative apparatus of all States shows, - Ivan Tarasov

\footnotetext{
1 Official website of the Ministry of internal Affairs of Ukraine. URL: http://www.mvs.gov.ua Official website of the Ministry of internal Affairs of Ukraine. URL: http://www.mvs.gov.ua/.
} 
wrote, - that irrespective of presence or absence of obvious, direct, conscious offenses and deviations from an office order, in activity of any administration such actions and orders which essentially violate the lawful rights and interests of citizens are always possible, are neither crimes, nor civil untruth, nor errors on service.

In such actions and orders of the administration lies the essence of the so-called "administrative untruth. In comparison with criminal untruth, administrative untruth, according to I. Tarasov, is an offense of a more subtle and complex nature. To effectively counteract administrative injustice, he considered it necessary to introduce administrative justice and create a system of administrative courts. He saw the functional purpose of administrative courts not in imposed penalties and punishments, but only in cassation or direct cancellation of illegal acts of administrative power. Responsibility by decision of the administrative court. T. Tarasov formulates as administrative responsibility that is responsibility for Commission of administrative (administrative) offense and separates it from other judicial responsibility ${ }^{2}$.

The legal properties of this lie he reduces to this:

a) it can only come from the administration, due to this, its scope is limited, on the one hand, civil untruth, and on the other - criminal untruth;

b) regardless of the scope and content of the relations that it affects, administrative untruth has a General, public (and not private) value;

c) it always takes the form of a legal administrative act of the administration exercising its powers;

d) it has the character of a potentially ongoing, repeatedly repeated lie.

Proceeding from the fact that administrative untruth is a specific encroachment on the right (it is not a crime, is not a civil untruth, is not an error in the service or a disciplinary offense), Etc. Tarasov comes to this conclusion: in order to protect the rights and interests of citizens from administrative injustice (illegal actions of the administration or administrative offenses) and ensure the rule of law in the management of the existing at the time of judicial or disciplinary responsibility is not enough to effectively counter administrative injustice, he considers it necessary to introduce administrative justice and create a system of administrative courts. In his opinion, the administrative courts will ensure by constant monitoring the legality of the orders and actions of the administration. He saw the functional purpose of administrative courts not in imposing penalties and punishments, but only in cassation or direct cancellation of illegal acts of administrative power.

\footnotetext{
${ }^{2}$ National police. A temporary web site. URL: http://www.npu.gov.ua/uk/
} 
Responsibility by decision of the administrative court. I. Tarasov formulates as administrative responsibility that is responsibility for Commission of administrative (administrative) offense and separates it from other judicial responsibility.

Administrative (administrative) offenses were called illegal unintentional acts exclusively of the administration (and not citizens) without individualized fault of a particular official, if they were not provided for in criminal law and did not have a civil wrong ${ }^{3}$.

Responsibility for administrative offenses was the restoration of the violated right, was provided by a single (at that time) type of administrative penalties-the abolition of the illegal act by the administrative justice authorities. Compensation for material damage caused by this act (action) occurred in the framework of criminal or civil proceedings. Historical analysis shows that the emergence of the concept of "administrative offense" is associated with attempts to improve criminal legislation by distinguishing criminal offenses by the degree of public danger.

This distinction was most successfully made in the French Code of 1795. It distinguished: a) crimes-acts for which corporal punishment was provided; b) misdemeanors or torts-acts for which punishments of a correctional nature were provided.

Over time, this classification has become dominant in many European countries. Gradually, the classification is simplified, but the separation of manifestations of criminally punishable illegal behavior into actual crimes and minor crimes (misdemeanors, torts), which later receive the name of criminal offenses or police offenses, or torts, remains fundamental. In Russia, it acquires practical and doctrinal significance with the introduction of the criminal and correctional punishment Ordinance (1845). In this act, the words "crime" and" misdemeanor" received the status of legal terms and began to denote different degrees of public danger acts.

Subsequently, such offenses began to be defined as administrative. Such clarification was connected with procedural features of application of punishments under the criminal legislation of the Russian Empire. According to the General provisions punitive power in Russia was concentrated in the courts. Cases of minor crimes (or misdemeanors) were considered specifically for this purpose by magistrates 'courts. But in 1889, the institution of magistrates "courts was abolished, and the functions of considering cases of misconduct were transferred to administrative bodies.

${ }^{3}$ Scientific and practical comment of section IV "Powers of police" and V "Police measures" of the Law of Ukraine "on National police"/ T. Minka, G. Mironyuk, V. Glukhoverya, etc.; for zag. ed. Kharkiv: Pravo, 2016. 178 p. 
From now on, minor crimes, or criminal offenses, which by their nature are actions of a criminal nature, begin to be referred to as "administrative offenses" ${ }^{4}$.

All of the above allows us to draw such a conclusion. Offenses that today in theory, in practice and in the legislation are understood as administrative, in theory, in practice and in the legislation of pre-revolutionary Russia were understood as unimportant crimes or offenses (police offenses, torts).

Sanctions from their Commission carried out exclusively punitive functions provided in the criminal legislation, and their essence did not change neither from an administrative order of application, nor from establishment by administrative body. In the latter case, the administrative body established the composition of the acts and the punishment for their Commission.

Understanding of concepts of administrative (administrative) offense and administrative offense (tort) which in the legal theory of the Russian Empire were formed actually according to the European standards, after October, 1917 begin to change.

In official sources, they are gradually beginning to be interpreted as synonymous terms, meaning the acts of individuals who violate the prohibitions established by the state and entail an administrative procedure for the application of penalties.

In accordance with ideological and political attitudes, a doctrinal basis is developed. Legislative consolidation of this approach gets in the Fundamentals of the USSR and the Union republics on administrative offenses [1980], in article 7 used the following wording: "administrative offense (misdemeanor) is recognized...". Thus, the position of the legislator regarding the adequacy of the concepts of "administrative offense" and "administrative offense" was fixed ${ }^{5}$.

No change this design moved to the CAO of Ukraine 1984.

So, in Soviet times, in fact, in all scientific works of both specialistsadministrative and representatives of other legal Sciences, these terms are used as synonyms.

During the time of independence, the development of issues of administrative offense (misdemeanor) retains the trends of the previous (Soviet) period and is actually carried out within the limits defined by article 9 of the administrative Code of the USSR and the commentary to it, written by L. V. Koval.

\footnotetext{
${ }^{4}$ Administrative law of Ukraine. Academic course: Studies.: In 2 vols. / Ed. Collegium: V. Averyanov (head). Kyiv: Yuridicheskaya Mysl, 2004. Vol. Common part. 584 p.

${ }^{5}$ Demsky, E. Administrative procedural law of Ukraine: studies. benefit. / E. Demsky. Kyiv: Yurinkom Inter, 2008. 496 s
} 
The analysis of numerous changes in the CAO both in Soviet times and during the years of independence of Ukraine shows that they were made to this article once - in 2001. These changes concerned only the fixation of socio-political

they did not affect the essential characteristics of the administrative offense (misdemeanor). Thus, the words "legislation" (in part one) and "current legislation" (in part two) were replaced by the words "law" and "law" respectively, and the words "state or" and "socialist" were deleted. The wording of article 9 of the CAO with the mentioned changes remains in force to this day.

He was the first in the modern history of Ukrainian administrative law to characterize administrative misconduct. P. Golosnichenko in the monograph "Prevention of selfish misconduct by means of administrative law" (1991).

In 1994, L. Koval gave the first course of lectures on administrative law since independence, in which, in comparison with the text of the commentary (1991), article 9 of the administrative Code of the Ukrainian SSR actually clarifies his position in the discussion on the concepts of public danger and harmfulness of misconduct and confirms his view on the presence of such a sign as punishability.

A. Ostapenko was the first in the Ukrainian administrative law in the work of the monographic level "Administrative delictology" (1995), offers the legislator a new definition of administrative tort:"... administrative tort is socially harmful (dangerous), illegal, guilty actions or inaction provided by the law, committed by a person in a particular place under certain conditions during the encroachment on public relations, which are protected by law."

V. Dodin in the course of lectures "administrative delictology" (1997) expresses several principled opinions on the essence of administrative misconduct. First, he notes that the administrative tort is qualitatively different from the crime, and this quality is legislatively defined the possibility of administrative responsibility for the absence of guilt ${ }^{6}$.

Today, the attention of researchers is attracted by the identification of the concepts of "administrative offense" and "administrative offense" by the legislator. Unfortunately, as a rule, in modern literature, their analysis is based on a purely linguistic and criminological interpretation of concepts without taking into account the historical roots of the appearance in law and legislation of the term "offense".

This approach has led to the conclusion that administrative misconduct is a specific type of offense for which administrative liability measures are applied.

\footnotetext{
${ }^{6}$ Administrative law of Ukraine. Academic course: Studies.: In 2 vols. / Ed. Collegium: V. Averyanov (head). Kyiv: Yuridicheskaya Mysl, 2004. Vol. Common part. 584 p.
} 
Now the first who broke the problem of the Genesis of administrative violations in the domestic legal and administrative science were V. Kolpakov. In the framework of his dissertation research "Deliktny phenomenon in administrative law of Ukraine" (2005) Kolpakov explores the historical and legal nature of administrative misconduct, ontological and epistemological approaches to the problem of administrative misconduct and a number of other problematic issues on this topic.

It is V. Kolpakov, I. Golosnichenko who can be considered the founders of the most radical, most effective and largely coinciding with the needs of modern practice of lawmaking and law enforcement, the concept of renewal of administrative-tort law and administrative misconduct, in particular.

The modern concept is based on the idea of A. Koval on a three-part system of administrative torts. He considered expedient allocation in all array of administrative offenses: a) administrative offenses of the increased degree of public danger; b) administrative offenses of insignificant public danger; b) administrative violations of primary character which are socially dangerous only in "General weight".

Taking into account this concept, scientists develop the rationale for the formation in the future of the institution of criminal misconduct, and in the modern, transitional period-the defendant's misconduct. To this end, a new codified act-the Code of Ukraine on defendants and administrative offenseswas proposed and developed at the time.

\section{The concept and signs of an administrative offense}

The society has a significant number of different kinds of legally binding rules, standards, requirements that are established or authorized by the state. Such rules are intended to regulate public relations, normalize certain procedures, actions, law enforcement and proper discipline in certain areas of activity. The rules of conduct established by the state directly affect the interests of all or most citizens, enterprises, institutions and the state as a whole ${ }^{7}$.

Such mandatory rules include rules of conduct in public places, traffic rules, rules of labor protection and safety, requirements of administrative regimes, sanitary, the procedure for the formation of prices and tariffs, licensing procedures, fire requirements, customs procedures, etc.

Compliance with these rules, norms, standards, requirements and procedures corresponds to the public interest, that is, the interests of everyone and the state as a whole, and their violation contradicts them and causes harmful and socially dangerous consequences.

\footnotetext{
${ }^{7}$ National police. A temporary web site. URL: http://www.npu.gov.ua/uk/
} 
All these rules shall be established by the laws and by-laws of the subjects of public administration, issued by them within their competence. One of the properties of these rules is that they are protected by administrative sanctions, and their violation is recognized as administrative offenses.

In the scientific literature for more than 50 years there is a discussion about the concept of which it is necessary to designate the fact of behavior that does not comply with the generally established rules, violates them. The legislator uses two concepts: an administrative offense and an administrative offense (article 9 of the administrative code), which already suggests the idea of the correlation of these concepts. In addition, there is the concept of administrative tort. The existence of these three terms is explained by an attempt to distinguish between administrative and criminal cases, as well as violation of labor discipline ${ }^{8}$.

General features and legal characteristics of administrative offenses contained in the administrative Code of Ukraine. The analysis of articles of the code shows that the legislator uses two approaches to fixing of signs of an offense which is recognized administrative.

In the first case, a list of specific features is provided. Thus, according to article 9 of the administrative Code, an administrative offense is an illegal, guilty (intentional or careless) action or inaction that encroaches on state or public order, property, rights and freedoms of citizens, on the established order of management and for which the legislation provides for administrative responsibility.

In the second case, the legislator uses a term that is a generalized abstraction. Denotes not specific actual actions and their consequences, and the results of the scientific theory of administrative misconduct. This generalized term is the legal composition of an administrative offense. For example, article 247 of the administrative code, "Circumstances precluding the proceedings of an administrative offense" States that the proceedings of an administrative offense cannot be initiated, and started to be closed in the absence in act of structure of an administrative offence.

From this it follows that the composition of the offense is a set of its features that allow among all manifestations of illegal behavior to distinguish administrative offenses.

Signs characterize the General socio-psychological nature of an act, recognized as an administrative offense.

${ }^{8}$ Scientific and practical comment of section IV "Powers of police" and V "Police measures" of the Law of Ukraine "on National police"/ T. Minka, G. Mironyuk, V. Glukhoverya, etc.; for zag. ed. Kharkiv: Pravo, 2016. 178 p. 
Elements of the legal composition solve another problem, they allow to qualify the acts as illegal and bring the perpetrators to administrative responsibility if the persons are delinquent.

Thus, the signs of an offense are the result of practical activity, empirical knowledge, the truth of fact, and the legal composition is the result of scientific activity, theoretical knowledge, the truth of reason ${ }^{9}$.

According to V. Kolpakov, the criteria for classifying acts as administrative torts are: a) the presence of public danger in the act and its characteristics; b) violations of public interests by the actions of a person; c) the absence of such a sign in the act as a violation of actually existing contractual obligations.

We will use these concepts as identical.

The following General legal signs characterize an administrative offense: first, it is an action or inaction - that is, behavior, act, and act of external relation of a person to reality, other persons, and the state society. Namely, the act, not thoughts, desires or other similar manifestations of mental activity of people;

Action - the active form of behavior of the person directly connected with non-performance of the legal instruction in the form of an obligation or legal requirement, violation of the ban, rule, norm, standard (for example, small hooliganism, unauthorized occupation of the land plot, violation of traffic regulations, illegal trade activity, arbitrariness).

Inaction is a passive form of behavior, which is reflected in the failure of a person to perform those actions that she should and could perform as a result of the duties assigned to her (for example, evasion of filing a Declaration, contempt of court, failure to comply with the legal requirements of the Prosecutor).

Illegality is the Commission of an act that violates the generally binding norms and rules of administrative and other branches of law (labor, land, financial, etc.), protected by measures of administrative coercion, or Vice versa does not commit the action that must be taken. Wrongfulness means that a legal norm prohibits a particular action.

For example, public calls for failure to comply with the legal requirements of a police officer are prohibited by article 185-7 of the CAO. In addition of the wrongfulness of States and when the offence is failure to comply with the requirements of the authorized body on elimination of violations of law (failure to perform the requirements of the bodies exercising state sanitary control, failure to comply with lawful requirements of the police);

9 Administrative law of Ukraine. Academic course: Studies.: / T. Kolomoets. Kyiv: Yurinkom Inter, 2011. 576 p. 
- guilt which assumes the presence of a person's independent mental attitude to the relevant act and its consequences. Such an act as a manifestation of the will and consciousness of a person must always be guilty, that is, committed intentionally or by negligence. When there is no guilt, the act cannot be recognized as an offence;

- administrative punishability, which means that a specific illegal, guilty act will be recognized as an administrative offense only when the legislation provides for an administrative sanction for its Commission;

- antisocial orientation (this feature is often identified with public danger or public harm). Any violation of the law, encroaching on the established law and order, entails him one or another harm, violates the order, consistency, harmony of management relations. At the same time, a negative result can be manifested both in reality (petty theft) and in creating conditions for the occurrence of harm (violation of sanitary and hygienic and sanitary anti-epidemic rules). According to the degree of social significance, an act that harms the legitimate interests of the state, FL, JL is anti-social.

In this context, it should be noted that in the legal literature there are several points of view as to whether an administrative offense is socially dangerous or socially harmful.

The first concept (public danger administrative tort) is based on the fact that all illegal acts and crimes, and administrative or disciplinary or civil offenses is to a certain extent socially dangerous. That is, all of them pose a threat to the normal functioning of society; violate generally recognized rules, norms and standards ${ }^{10}$.

This approach is reflected in the position of the legislator: there are situations when acts that are recognized as crimes are further recognized as administrative offenses, or Vice versa. An example is petty hooliganism, which was recognized as a crime, then as an administrative violation or smuggling, which was initially recognized as an administrative tort, and now it is a crime under the criminal code of Ukraine. As we can see, the legal properties of these acts did not change, but only their legal assessment changed. A landmark in this sense is speculation, which was previously recognized as a tort, and now is a type of economic activity.

The definition of the concept of crime (article 2, 11 of the criminal code of Ukraine), administrative offense provides for the differentiation of these concepts is taking into account the degree of public danger.

The second concept (harmfulness of administrative offenses) is based on the fact that administrative offenses are a special type of offense, and their Commission has no public danger, but only entails harmful consequences.

${ }^{10}$ National police. A temporary web site. URL: http://www.npu.gov.ua/uk/ 
The legislator also supports this concept: in articles 10,11 of the CAO, where it is a question of committing an offense intentionally or carelessly, it is a question of harmful consequences. Article 259 of the CAO States that the harm may be moral, physical or property.

V. Kolpakov proposes to fundamentally change the approach to this problem. The refusal to consider the ratio of public danger and harm from the standpoint of their specific weight in certain groups of torts and the application of ontological-epistemological approach to the tort as a legal phenomenon, allowed us to come to the following conclusion: harm ontological category inherent in the act; public danger - epistemological category inherent in the offense.

The existence of harm, as a rule, is established by the description which in itself already acts as the proof of harmfulness of the corresponding act. Public danger is an epistemological category. It cannot be established by an ontological description of what happened. It is proved by the investigation of all the signs and characteristics of the fact of reality, and in our case - the offense. Research of all complex of properties of offense is carried out in the corresponding organizational forms-cases on administrative offenses. Such cases are essentially epistemological impressions of a particular act. Investigation of the case is the knowledge (research) of the fact of reality, in the ontology of which there were signs of tort.

The above indicates that the existence of these competing concepts is, rather, the theoretical nature of these views, and in practice the property of all concepts is used, where they rationally combine, complement each other $^{11}$.

\section{Types of administrative offenses}

Specific types of administrative offenses are grouped in eleven chapters of the special part of the administrative Code of Ukraine and other legislative acts.

As already noted, the basis of such a grouping is based on two criteria, or as scientists believe, the object-industry principle.

At the same time, in administrative and legal science, administrative offenses are divided into simple and complex.

A simple act is a single one-time (one-act) action or short-term inactivity (for example, drinking alcohol in public places, theft or stowaway).

A complex wrongful act may consist of several independent actions and be stretched over time. There are the following complex actions:

11 Kolpakov V. Administrative responsibility (administrative-tort law): studies. no. / V. Kolpakov. Kyiv: Yurinkom Inter, 2008. 256 p. 
- with two different actions (for example, petty speculation, combining buying and reselling for profit);

178) those that consist of alternative actions (for example, committing domestic violence, failure to comply with a protective order or failure to undergo a remedial program (art. 173-3); drinking alcoholic beverages in public places or appearing in public places drunk (art. Each of the alternative actions in such cases is in itself a sufficient basis for bringing to administrative responsibility. However, a person does not commit a new offense if he consistently performs all prohibited actions specified in the disposition of the legal norm;

- those, that consist of teams action-speech about them can go in those cases, when objective side offense in as a constructive a sign of characterizes repetitiveness action, as would she not was called: in camping on champion repetitiveness, systematicity, viciousness and the like (violation of rules content cats and dogs (St. 154), repeated violation by the official of rules and instructions on safe conduct of works, malicious disobedience (185), etc.);

- continuing offenses, that is, those that began with any illegal action or inaction, then continue continuously by non-performance (violation) of duties (for example, storage and carrying of hunting weapons without permission (Art. 190), individual violations of fire safety rules (art. 120), passport rules (Art. 197 Accommodation without a passport), rules of military registration (210), etc.);

- continuing offenses, that is, those that consist of several identical illegal actions related to each other and aimed at achieving a common goal, and which together form a single administrative offense. Such an offense is committed not continuously, but in separate episodes, internally closely related, but separated in time, which act as links in a chain (for example, individual cases of malicious failure of parents to raise and educate children (art. 184), violation of the rules of administrative supervision (art. 187), systematic violation of the rules of hunting, prostitution (art. 181-1), etc.).

Depending on the presence of harmful effects emit:

- formal structure of an offense-such which in the design does not provide as a result of its Commission of approach of any specifically-certain socially dangerous or harmful consequence. Only the fact of violation of this or that rule or norm is ascertained (for example, violation of sanitary and hygienic rules (Art. 42), violation of rules of land use, small hooliganism (art. 173), malicious disobedience (art. 185), etc.).

- the material composition of an administrative offense includes, in addition to the illegal action, a mandatory offensive as a result of their Commission of socially dangerous or harmful consequences (for example, 
art. 89 CAO Cruelty to animals; art. 124 violation of traffic rules, resulting in damage to vehicles, goods, roads, etc.; art. 170 administrative Code Noncompliance with standards during transportation, storage and use of products);

- Most administrative offenses are characterized by formal compositions $^{12}$.

Domination of formal structures is directed on prevention of administrative offenses, prevention of approach of real harmful consequences.

In the qualification of material warehouses, the causal link between the wrongful act and the harmful consequences must be clearly traced. In some cases, their size serves as a criterion for the qualification of an illegal act as an administrative offense, or as a crime (for example, theft, violation of currency rules, possession of drugs, smuggling, etc.).

The content of the objective party may include the nature of the repetition of the act:

- repetition is Commission by the same person within a year of a homogeneous offense for which it was already subjected to administrative penalty;

- repeated - Commission of two or more homogeneous administrative offenses provided by a specific article of the administrative Code (Art. 178. Clever drinking beverages in public places and emergence in public places in a drunken state). It qualifies as a single offense;

- malice characterizes persistence, clearly expressed unwillingness of the offender to obey repeatedly expressed legal requirements, warnings of the authorized person, the representative of the power (malicious disobedience to the lawful order of the serviceman, the militiaman);

- systematic - Commission of an offense within one year several times (more than 3 times), and in any one sphere, by the same subjects (for example, systematic violation by drivers of traffic rules).

In the current legislation of Ukraine on admittance nothing is specifically indicated in relation to the attempt on an administrative offense, as well as complicity in it.

Among the signs of the objective side of individual crimes, the legislator often points to the sign of "another person" (for example, malicious disobedience to the request of a police officer, molestation of foreign citizens, bringing minors to a state of intoxication, etc.).

${ }^{12}$ Course of administrative law of Ukraine: Textbook/ V. Kolpakov, O. Kuzmenko, I. Pastukh, V. Sushchenko / ed.. V. Kovalenko. Kyiv: Yurinkom Inter, 2012. 808 p. 
Sometimes separate legal signs of the objective party are included by the legislator directly in a construction of this or that legal norm and acquire qualifying value. These are signs concerning:

- time of Commission (for example, violation of silence at night, hunting in the forbidden terms);

- places of its Commission (for example, appearance in public places in a state of intoxication, drinking alcoholic beverages at work, hunting in prohibited places);

- conditions (for example, violation of certain sanitary-quarantine, technical, natural conditions, creation of conditions for holding mass events in violation of the established order);

- methods (for example, cruelty to animals, malicious evasion of appearance in court);

- means of committing an offense (for example, vehicles, prohibited hunting tools, drugs, etc.).

\section{CONCLUSIONS}

1. Offenses in essence covers all acts that violate the established law (in its broadest sense) the procedure for the implementation of rights, freedoms and interests, as well as the implementation of duties. Any discrepancy of actual circumstances to legal requirements shall be interpreted as an offense taking into account features of methods of legal regulation of public relations in which the rights, freedoms and interests are realized, duties are carried out.

Misconduct, in our opinion, must first of all be identified with the existence of prohibiting norms, which must clearly define acts that are indisputably recognized as socially harmful and socially dangerous. Now there is a need to legally consolidate the concepts of "offense" and "misdemeanor", which guarantees effective mechanisms associated with the effective implementation of citizens of their rights, freedoms and interests, as well as protect both the individual and society as a whole from socially harmful events caused by illegal actions of subjects.

2. An administrative offense (misdemeanor) is an illegal, guilty (intentional or careless) action or inaction that encroaches on public order, property, rights and freedoms of citizens, on the established order of management and for which the law provides for administrative responsibility (article 9 of the CAO).

The law contains two terms at the same time: "administrative offense" and "administrative offense", but the latter is not a special type of administrative offense. 
An administrative offense (misdemeanor) is characterized by a number of signs. It is, first, an act, behavior, act of a person, action or inaction, as well as an act of external expression of the person's attitude to the real activities of other people, society, and the state. The law is not subject to the beliefs, thoughts of people, if they have not found an external manifestation.

3. There are two types of administrative offenses:

- Most misdemeanors do not border on criminal offenses and under no circumstances will they escalate into crimes.

- Border crimes (for example, article 51, article 173 of the CAO).

We have no pronounced and clearly defined criteria that define a criminal offense and two groups of administrative offenses. Such a distinction should be made on certain grounds specified in the legislation. For example, petty theft of another's property (article 51 of the administrative code) and criminal theft (article 84 of the criminal code of Ukraine) are distinguished by the value of the stolen or the method of abduction. From the point of view of the legislator such differentiation should be carried out persons (taking into account character and personal features of the offender). Finally, administrative action is considered inaction (act) with the achievement of a certain result.

\section{SUMMARY}

Offences that today in theory, in practice and in legislation are understood as administrative, in theory, in practice and in legislation prerevolutionary Russia were understood as unimportant crimes or misdemeanors (police misdemeanors, torts).

Sanctions from their Commission carried out exclusively punitive functions provided in the criminal legislation, and their essence did not change neither from an administrative order of application, nor from establishment by administrative body. In the latter case, the administrative body established the composition of the acts and the punishment for their Commission.

Understanding of concepts of administrative (administrative) offense and administrative offense (tort) which in the legal theory of the Russian Empire were formed actually according to the European standards, after October, 1917 begin to change.

In official sources, they are gradually beginning to be interpreted as synonymous terms, meaning the acts of individuals who violate the prohibitions established by the state and entail an administrative procedure for the application of penalties.

In accordance with ideological and political attitudes, a doctrinal basis is developed. Legislative consolidation of this approach gets in the 
Fundamentals of the USSR and the Union republics on administrative offenses (1980), in article 7 used the following wording: "administrative offense (misdemeanor) is recognized...". Thus, the position of the legislator regarding the adequacy of the concepts of "administrative offense" and "administrative offense" was fixed.

\section{REFERENCES}

1. Administrative law of Ukraine. Academic course: Studies: / T. Kolomoets. Kyiv: Yurinkom Inter, 2011. 576 p.

2. Administrative law of Ukraine. Academic course: Studies: In 2 vols. / Ed. Collegium: V. Averyanov (head). Kyiv: Yuridicheskaya Mysl, 2004. Vol. Common part. $584 \mathrm{p}$.

3. Demsky, E. Administrative procedural law of Ukraine: studies. benefit. / E. Demsky. Kyiv: Yurinkom Inter, 2008. 496 s

4. Kolpakov V. Administrative responsibility (administrative-tort law): studies. no. / V. Kolpakov. Kyiv: Yurinkom Inter, 2008. 256 p.

5. Course of administrative law of Ukraine: Textbook/ V. Kolpakov, O. Kuzmenko, I. Pastukh, V. Sushchenko / ed. V. Kovalenko. Kyiv: Yurinkom Inter, 2012. $808 \mathrm{p}$.

6. Scientific and practical comment of section IV "Powers of police" and V "Police measures" of the Law of Ukraine "on National police" / T. Minka, G. Mironyuk, V. Glukhoverya, etc.; for zag. ed. Kharkiv: Pravo, 2016. 178 p.

7. National police. A temporary web site. URL: http://www.npu.gov.ua/uk/

8. Official website of the Ministry of internal Affairs of Ukraine. URL: http://www.mvs.gov.ua Official website of the Ministry of internal Affairs of Ukraine. URL: http://www.mvs.gov.ua/.

Information about the author: Popovich Ye. M., Doctor of Law, Professor, Professor at the Department of Administrative, Criminal Law and Procedure, International University of Business and Law 37-A, 49 HGD str., Kherson, 73040, Ukraine 


\section{DOCUMENTATION OF ADMINISTRATIVE ACTIVITIES BY THE POLICE OF UKRAINE}

\section{Predmestnikov O. G.}

\section{INTRODUCTION}

The work is supposed to consider the documentation of administrative offenses by the police, namely the bringing of protocols on administrative offenses, decisions in the case of an administrative offense and the rules by which they are drawn up.

\section{Documentation of administrative offences by the National police of Ukraine}

According to item 1 of section II of the Instruction on registration of materials on administrative offenses in police bodies approved by the order of the Ministry of internal Affairs of 06.11.2015 No. 1376 protocols on: administrative offense; administrative detention; withdrawal of things and documents; inspection of things and personal inspection, and also receiving explanations from persons who are brought to administrative responsibility, victims, witnesses are carried out by authorized officials of police bodies ${ }^{1}$.

About Commission of an administrative offense, the Protocol is made.

Authorized officials of the police shall carry out preparation of protocols on administrative offenses, protocols on administrative detention, and protocols on seizure of things and documents, protocols on inspection of things and personal inspection, as well as obtaining explanations from persons brought to administrative responsibility, victims, witnesses.

On Affairs about administrative offences, the consideration of which is within the competence of the police authorities referred to in article 222 of the CAO, protocols in accordance with article 255 of the CAO be authorized officials of these bodies.

Protocols on administrative offences shall not be drawn up in cases provided for in article 258 of the CAO.

If, during the judgement in the case of an administrative offence the person contesting the violation and the administrative penalties that it imposed, the authorized official person of the police authority is obliged to draw up a Protocol on administrative offense under article 256 of the CAO,

${ }^{1}$ Krasnitskaya A. Problems of formation of definition of legal technique in post-Soviet times. Scientific Bulletin of KNUVD. 2010. 
except bring the person to administrative responsibility for committing an administrative offense under article 185-3, Art.

In case of Commission of an administrative offense by persons who have reached the age from which administrative responsibility comes, the authorized officials of police bodies make the Protocol on an administrative offense $^{2}$.

At insignificance of the made administrative offense the body (official) of police authorized (and) to consider business, can release the violator from administrative responsibility and be limited to the oral remark.

Administrative Protocol is a procedural document of different content and purpose, with the help of which an official or a representative of a public organization records the Commission of an administrative offense.

The Protocol on administrative offense is made on the special form which is made by the typographical method.

The form of the Protocol on an administrative offense is a sheet of paper with a size of $210 \times 297 \mathrm{~mm}(+-0.5 \mathrm{~mm})$ weighing $80 \mathrm{~g} / \mathrm{sq}$. $\mathrm{m}$ and consists of a Protocol and a copy. The Protocol and the copy are printed on self-copying paper from the front side in three colors by means of offset printing. On the form of the Protocol on an administrative offense the perforation line at distance of $20 \mathrm{~mm}$ from the left edge is put. The Protocol series consists of a letterhead, a number, and a six-digit numeric index, performed by highresolution printing ${ }^{3}$.

The text part is printed in green paint. The Protocol form itself is protected by small security elements:

1) micro shrift in the positive image on the Protocol and a copy of the form;

2) an irregular computer background grid for the Protocol, which is executed in blue and for the copy in yellow.

The Protocol indicates the name of the manufacturer, number, year and quarter of the order is printed on the front side of the Protocol and a copy.

All protocols on administrative offenses are completed with blocks of 20 copies. After the last copy, the block is completed with a clean cardboard page.

The Protocol on administrative offense is filled in ink of black or blue color, legible handwriting, in the state language.

\footnotetext{
${ }^{2}$ Tertyshnyk V. Criminal procedure law of Ukraine: textbook. The 4th form., additional and pererab. K.: A. S. K. publishing House, 2017. 1120 p.

Krasnitskaya A. Law enforcement errors in the texts of procedural acts of criminal proceedings. The court of appeal. 2016. No. 1. P. 28-33.
} 
The Protocol on an administrative offense is formed in two copies, one of which is handed over to the person brought to administrative responsibility under the receipt. In drawing up the Protocol on administrative offense the person brought to administrative responsibility, shall be explained his rights under articles 55, 56, 59, 63 of the Constitution of Ukraine, article 268 of the administrative code, it is reported that the case of an administrative offense will be dealt with in the terms defined by the article 277 of the CAO, which is the mark and signature of the person, brought to administrative responsibility.

The person brought to administrative responsibility has the right to submit explanations and remarks concerning the contents of the Protocol on an administrative offense and explanations on the essence of an administrative offense which are attached to the Protocol on an administrative offense, and also to state motives of the refusal to sign it. If the person against whom the Protocol on an administrative offense is drawn up does not speak the Ukrainian language, the Protocol on an administrative offense is drawn up with the participation of an interpreter ${ }^{4}$.

In the Protocol on administrative violation shall contain: date and place of its execution, position, surname, name, patronymic of the person who made the report; information about the person, brought to administrative responsibility (in the case of her identification); place, time of committing and the essence of the administrative offence; the normative act providing responsibility for the offense; the names, addresses of witnesses and victims, if any; an explanation of the person, brought to administrative responsibility; any other information needed for resolution of the case. If the offense caused material damage, this is also indicated in the Protocol. Thus:

- in the column "place of drawing up the Protocol" the settlement or geographical point is specified;

- in the column "position, name of police body, rank, surname, name, patronymic of the person who made the Protocol" the surname, name, patronymic of the official who made the Protocol is specified (completely, without abbreviations);

- in the column "made this Protocol that the citizen" it is necessary to specify a surname, a name and a patronymic of the person brought to administrative responsibility (completely, without reductions);

- in the column "Title of document, series, number, whom and when issued" reflects the identity document (series, passport number, date of issue and name of the authority that issued it, or number of other identity document, commits an offence (service or pension certificate, student ID,

\footnotetext{
${ }^{4}$ Kashanina T. Legal technique: student. Moscow: Eksmo, 2011.
} 
etc.), date of issue and name of the body (institution, enterprise, organization) which issued it (and));

- in the column "or was brought (Las) to administrative responsibility" should contain information on attraction of the person to administrative responsibility within a year (in the presence of);

- in the column "date, time, place of Commission and the essence of an administrative offense" is necessary to explain the essence of the administrative offense (must exactly match the signs of an administrative offense specified in article of the administrative code, according to which the Protocol);

- in the column "to the Protocol is attached" explanations of the person who has committed an administrative offense are specified, are stated on a separate sheet, reports of officials of police bodies, certificates, acts, etc. (in case of drawing up).

The authorized official who made it signs the Protocol on an administrative offense, and the person brought to administrative responsibility. In the presence of witnesses and victims the Protocol on an administrative offense can be signed also by these persons. In case of refusal of the person brought to administrative responsibility to sign the Protocol on an administrative offense in it record about it becomes ${ }^{5}$.

To the person concerning whom the Protocol on an administrative offense is made, it is offered to provide on the merits of the committed administrative offense the written explanation which is signed by the specified person. The explanation can be attached to the Protocol on an administrative offense separately about what record in it becomes. Other materials on administrative offense (explanations of victims, witnesses, expert opinion, physical evidence, Protocol on seizure of things and documents, reports of officials, as well as other documents and materials containing information about the offense) are also attached to the Protocol on administrative offense.

In any case, it is not allowed to cross out or correct the information that is entered in the Protocol on an administrative offense, as well as to make additional entries after the Protocol on an administrative offense is signed by the person in respect of whom it is drawn up.

The Protocol on an administrative offense, in case of its registration, is made in two copies, one of which under the receipt is handed over to the person brought to administrative responsibility.

\footnotetext{
${ }^{5}$ Samples of civil legal documents: scientific and practical guide / ed. V. A. Kuznetsov. Kiev: Istina, 2017. 712 p.
} 
If the offense is committed by several persons, the Protocol on an administrative offense is made concerning each person separately.

The Protocol on an administrative offense and materials on the committed administrative offense are sent to the body authorized to consider cases on administrative offenses ${ }^{6}$.

In case of Commission of an administrative offense by the minor at the age from fourteen to sixteen years the Protocol on an administrative offense as a General rule is made concerning one of parents of the minor or the person who replaces them, according to part three of article $184 \mathrm{CAO}$. The exception takes place on condition of Commission by the minor person at the age from sixteen to eighteen years of the administrative offenses provided by articles 44, 51, 121-127, h. 1-3 of Art. 130, Art. 139, h. 2 of Art. 156, art. 173, 174, 185, 190-195 CAO, the Protocol on an administrative offense is made concerning this person.

The Protocol on administrative detention of the person who has committed an administrative offense is made on the special form made by the printing method. The technical requirements for the form of the Protocol on administrative detention are identical to the requirements for the Protocol on administrative offense. Completed copies in blocks of 30 pieces.

The Protocol on administrative detention shall specify: the date and place of its preparation; the position, surname, name and patronymic of the person who drew up the Protocol; information about the identity of the detainee; time and motives of detention. Thus:

- in the column "position, name of the police body, rank, P. I. the person who made the Protocol" the surname, a name, a patronymic of the official who made the Protocol (completely, without abbreviations is specified);

- in the column "grounds for detention: suppression of an administrative offence, Protocol of administrative offence for consideration of the case" indicates the termination of administrative offences or other measures of exposure;

- the Protocol on administrative violation in case of failure of drafting him in the Commission of an offense if the preparation of a Protocol is mandatory;

- ensure timely and lawful consideration of the case.

At drawing up the Protocol on administrative detention the official performing it, explains to the person who has committed an administrative offense, its rights provided by articles 55, 56, 59, 63 of the Constitution of

\footnotetext{
${ }^{6}$ Dutko A. General characteristics of the legal and technical norm-setting. Herald Of Lions. UN-Tu. 2000. Vol. 35. P. 48-51.
} 
Ukraine and article $268 \mathrm{CAO}$. According to the Law of Ukraine "On free legal assistance" and paragraphs 2, 10 the procedures for informing of the centers providing free secondary legal assistance about cases of detention of persons, approved by the decree of the Cabinet of Ministers of Ukraine of 28 December 2011 No. 1363, during a Protocol on administrative detention of a person who committed an administrative offense, shall be explained his right to free secondary legal aid $^{7}$.

Gratuitous secondary legal aid is a type of state guarantee, which consists in creating equal opportunities for persons to access justice. It includes the following types of legal services:

1) protection;

2) representation of the interests of persons entitled to free secondary legal assistance in courts, other state bodies, local self-government bodies, before other persons;

3) preparation of procedural documents.

All details of the Protocol on administrative detention are filled in legible handwriting. It is not allowed to cross out or correct the information that is entered in the Protocol on administrative detention, as well as to make additional entries after the Protocol on administrative detention is signed by the person against whom it is drawn up.

The Protocol shall be signed by the official who drafted it and the detainee. In case of refusal of the detainee from signing of the Protocol in it record about it becomes. In accordance with the second part of article 261 of the CAO, the place of stay of a person detained for committing an administrative offense is immediately reported to his relatives, and at her request to the owner of the relevant enterprise, institution, organization or body authorized by him. About it in the Protocol on administrative detention the corresponding record is made, the number, month, year and time to whom it is reported and in what way are specified.

In case of impossibility to inform relatives and in case of refusal of the detained person to provide information for their notification about it the corresponding record is made by the detained person and the official who made the Protocol on administrative detention, with indication of valid reasons.

The detention of a minor must be reported to his parents or persons who replace them. In the Protocol on administrative detention the time, date of the message, whom it is reported and how are specified.

\footnotetext{
${ }^{7}$ Michurin E. Technique of drafting contracts: scientific and practical guide. A series of "Practice and law". Kharkov : Urxvt, 2017. 536 p.
} 
Before being placed in the detention room duty of the police authority in the office where delivered to the person who committed an administrative offence under article 264 of the CAO by the duly authorized person of the same sex with the person who delivered, in presence of two witnesses (witnesses) of the same sex is a personal inspection and inspection of items delivered to the person ${ }^{8}$.

In urgent cases these things, objects can be subjected to inspection with the participation of two witnesses (witnesses) in the absence of the owner (owner).

About carrying out personal inspection and inspection of things the Protocol in which are specified is made:

- date, time, place of its compilation;

- the official of the police body who composed it (in full, without abbreviations);

- surnames, names and patronymics, places of residence of two witnesses (fully, without abbreviations);

- surname, name, and patronymic (in full, without abbreviations), the place of residence of the person who is examined and at whom examine things, values, documents which are the tool or object of an offense;

- signs of individual things, valuables and documents;

- places and circumstances of detection.

The Protocol of personal inspection and inspection of things is signed by the person who was subjected to the review and at whom examined things understood and the official of body of police who made it.

About personal inspection and inspection of things of the person who has committed an administrative offense, the corresponding record in the Protocol on an administrative offense or in the Protocol on administrative detention where are specified is made:

- surnames, names and patronymics, places of residence of two witnesses;

- a list of things being inspected, and items of clothing that are on her face at the time of her detention;

- information on the presence or absence of bodily injuries of the detainee. If injuries are found, it should be noted on which parts of the body they are and their nature (bruises, scratches, cut wounds, etc.).

If the detainee needs medical assistance, the official of the police body calls an ambulance. In the Protocol on an administrative offense time of rendering medical care, number of crew of emergency medical care, a

\footnotetext{
${ }^{8}$ Rona A. Collection of claims. practical guide. Kyiv: CST, 2017. 204 p.
} 
surname and initials of the doctor to whom establishments of health care of the detainee is directed are specified.

At receipt from the detainee during carrying out personal inspection, inspection of things of complaints or remarks in the Protocol on administrative detention the corresponding record with indication of their essence becomes.

When the detained person is released from the place of his stay, the Protocol on administrative detention is noted, in particular, in the column "complaints, comments to the actions of police officials do not have / have" and the presence or absence of comments and complaints about the actions of police officials, stating their essence.

According to article 265 of the CAO, things and documents that are the instrument or the direct object of an offence, identified during detention, personal search or police officials seize inspection of things. In the Protocol on an administrative offense or in the Protocol on administrative detention the corresponding record about what things, objects, documents which are the tool or direct object of an offense are withdrawn from the detainee is made, their individual signs, numbers, a place and circumstances of their detection are specified.

A conclusion is a document that records the thought, conclusion of a body (official), Commission or specialists on any issue, document or other materials. The opinion may be sent to a higher authority or official with subsequent approval.

The main details of the conclusion: the name of the type of document (Conclusion); title; text that contains an assessment of the work, comments and suggestions; special title, surname, initials of the originator; signatures; date.

The text of the conclusion consists of two parts. The first sets out the essence of the issue, which is considered, the facts and results of the audit, the second-formulated conclusions and proposals for the work carried out.

An explanation is a document that sets out events or facts that are relevant in the case in question.

Explanation you must specify the position, special title, surname and initials of the person against whom the explanation is made; the name of the document (Explanations); the date, place of writing; text; surname, initials and signature of the person who gave the explanation; the signatures of officials selected explanations, as well as persons who were present when the document (if required by law). Explanation, as a rule, is written by the person or the official with own hand about what record in explanation becomes.

All documents, wherever and by whom they are concluded, have legal, technical, logical and linguistic requirements. 
Legal requirement. The document is issued by an authorized body or person in accordance with its competence. The document should not contradict the current legislation and directives of the governing bodies, should be reliable and meet the tasks of the specific management, i.e. be based on facts and contain concrete and real proposals or instructions. The document must be in the prescribed form. It should be flawlessly edited and decorated. It does not allow legal and grammatical errors. The texts of business documents use the official business style.

Specifications. For the conclusion of any document, there is an appropriate white paper size. The generally recognized A4 format, the text of which is printed in one and a half line intervals, on A5 format forms-in one interval. Certain requirements and rules for page design and numbering have been developed and are in force in office work ${ }^{9}$.

At registration of documents on two and more pages, since the second, they should be numbered. The number is put down in the middle of the upper Bank of the page in Arabic numbers. Dots and dashes before and after numbers are not put. The page number is printed in the interval of 10-15 mm. from the upper shore. Business documents are typed with 14 pins in the Word editor (Times New Roman font), upper and lower indents $-2 \mathrm{~cm}$, left $-3 \mathrm{~cm}$, right $-1 \mathrm{~cm}$.

If the document is also drawn up on the reverse side (the shelf life of such a document should be no more than three years), the left and right banks on the back are respectively reversed.

The name of the document should be printed in 16 pins, large letters, bold and placed in the center of the line of the form.

The date in the document is written in Arabic numerals in one line in the sequence: number, month, year: 12.09.2006. If the serial number of the month or number consists of a single-digit number, then 0: 02.09.2006 is put before it.

Legal acts and financial documents use the word-digital method of registration of the date - September 15, 2006.

Logical requirements are characterized by the use of means of logical evaluation of the material for the coherence of the individual parts, indicating the order of implementation (first of all, at the same time, in particular, consequently); taking into account such elements as the relevance of the facts and their timeliness; the sequence of the text and its parts.

The logical sequence of presentation is especially expressive in those types of business documents, where subjective elements are completely

9 Krasnitskaya A. Procedural acts of criminal proceedings: legal technique, ways of improvement: abstract. dis. for the Sciences. the degree candidate. Yuri. sciences'. Kiev, 2008. 
excluded: manifestations of irritation, discontent, bringing a personal attitude to the case or the person in the text of the document.

Signs of logical sequence: close logical connection of all components of the document, clearly identified cause-and-effect relationships between the reported facts. The logical sequence of the business document can also be realized in other types of relationships: this opposition (it is most often expressed by words but, however); identification and logical assertion of the priority (now, later); target (to this end, for, so), effectiveness (therefore, thus, as a result, in General); this specification anywhere in the document (for example, in particular, for example).

The logical sequence of presentation is also achieved by clearly dividing the text of the document into separate paragraphs. External manifestations of this division are numbering, letters, paragraphs.

Linguistic requirements. The text of the business document is its basis, it must be competent. The written form of speech requires clear syntactic constructions, strict observance of stylistic norms and rules of grammar. In particular, language literacy is the observance of the norms of spelling, punctuation and grammar. All terms, special concepts, constructions formed under the influence of the peculiarities of professional thinking should correspond to the modern level of legal knowledge, be used only when they are really necessary.

The text of the document should be clear. The language of official documents is abstracted from the individual speech characteristics of people, which requires a certain formalization of the language, the use of standard terms, established language structures with established rules of their interpretation. (The choice of words and terms, sustainable speed (based on the above, in accordance with the requirements of the decree, pursuant to article of the criminal code of Ukraine is brought (filed) charges, etc.), sentence structure, form of presentation of document (order, offer, require, listened, acted, decided, please, send, sent for review and the like).

All of the above requirements for the preparation of documents constitute a common culture of speech of the individual, because the high culture of human speech determines perfect command of the literary language, the ability to correctly apply its norms in the process of speech activity ${ }^{10}$.

The concept of high culture of office work and culture of language of documents is realized in such specific requirements:

${ }^{10}$ Tertyshnyk V. Criminal procedure law of Ukraine: textbook. The 4th form., additional and pererab. K.: A. S. K. publishing House, 2017. 1120 p. 
- the document is issued by an authorized body or person in accordance with the competence;

- the document cannot contradict the current legislation, Directive instructions of governing bodies;

- the document should be reliable and consistent with the objectives of the specific management, that is, based on facts and contain specific real proposals or instructions;

- the document should be in the prescribed form;

- the document must be flawlessly edited and decorated.

The appearance of the document is an indisputable evidence of the management style, discipline and personal culture of employees.

\section{Administrative-procedural documents adopted during the proceedings in cases of administrative offenses}

An administrative decision is a procedural document that is drawn up after consideration of a case of an administrative offense by a body or official. In the resolution state and justify the decision made during administrative proceedings.

The decision of the Executive body of the village, village Council in the case of an administrative offense is taken in the form of a decision.

The form of the resolution on the case of an administrative offense is filled in legible handwriting. It is not allowed to cross out or correct the information that is entered in the decision, as well as making additional entries after the decision is signed by the person against whom it is made. In case of violations in the design of such a decision, its completed form is considered spoiled ${ }^{11}$.

When making a decision in the case of an administrative offense, it shall specify, in particular:

- in the column "position, name of the police body, rank, surname, name and patronymic of the person who made the decision" - surname, name, patronymic of the official of the police body who made the decision, and the police body (in full, without abbreviations);

- in the column "established" - number, month, year, time and place of Commission of an administrative offense, and also circumstances and an offense essence established at consideration of materials of administrative case;

- in the column "considering that citizen" - the surname and initials of the offender;

\footnotetext{
${ }^{11}$ Rona A. Collection of claims. practical guide. Kyiv: CST, 2017. 204 p.
} 
- in the column "decided" - the authorized official of the police body, taking into account and indicating the circumstances mitigating (article 34 of the administrative code) or aggravating (article 35 of the administrative Code) responsibility for an administrative offense, notes the decision taken in the case.

In the case of an administrative offence, the official of the police body that is considering it, in accordance with article 284 of the CAO, shall make one of these decisions:

1) on the imposition of an administrative penalty;

2) on closing the case.

The decision of the case on administrative offence is signed by the official who considered the case, and resolution of collegial body - the person presiding at the meeting and the Secretary of this body.

In cases stipulated by the legislation of Ukraine, the appropriate record on the Protocol on an administrative offense is made or the resolution is made out in another established way (article 283 of the Code of administrative offenses of Ukraine).

In the case of an administrative offense, the body (official) makes one of these decisions:

a) on the imposition of an administrative penalty;

b) about application of the measures of influence provided by Art. 24-1 of the Code about administrative offenses of Ukraine;

c) on closing the case.

After considering the case on administrative offence, depending on the results of its review authority which considered the materials of the administrative case and took out the decree, decides whether the seized documents or things, on their forfeiture in the prescribed manner, refund to the owner or destroyed, as recorded in the resolution. The resolution is signed by the official who made it.

The decision is announced immediately after the end of the consideration of the administrative case.

A copy of the decision in the case of an administrative offense within three days is handed over or sent to the person in respect of whom this decision is made. A copy of the decision on the case of an administrative offense is handed to the person brought to administrative responsibility, personally under the signature. In the decision on the case of an administrative offense the date of its delivery is specified and the signature of the offender is put. If a copy of the decision in the case of an 
administrative offense is sent by mail, the corresponding mark is made in the case, to which the spine of the mail notification of its receipt is attached ${ }^{12}$.

A copy of the decision on the case of an administrative offense in the same period is handed over or sent to the victim at his request (it indicates the date of its delivery and the signature of the person who received it).

According to article 293 of the CAO, an official of the police body authorized to consider cases of administrative offenses, when considering a complaint against a decision in an administrative offense case, checks the legality and validity of its issuance and takes one of the following decisions:

1) leaves the resolution of administrative proceedings without change, and the complaint and makes a decision on leaving the decision in the case of an administrative offense without change, but complaint or the Prosecutor without satisfaction;

2) repeals the decision on the case of an administrative offense and sends the case for consideration and makes a decision to cancel the decision on the case of an administrative offense and transfer the case to a new hearing;

3) cancel the ruling in the administrative proceedings and closes the case and makes a decision about cancellation of the resolution on case about administrative offense and dismiss the case;

4) changes the measure of recovery within the limits provided by the regulatory act on responsibility for an administrative offense, but without strengthening the recovery, and decide to change the measure of recovery.

A copy of the decision on the complaint against the decision within three days is sent to the person against whom it is made, in the same period a copy of the decision is sent to the victim at his request.

\section{Features of office work in cases of administrative offenses}

It should be noted that the proceedings in cases of administrative offenses has a number of specific features. So, forms of protocols on administrative offenses and protocols on administrative detention are documents of strict accounting and are printed with the indication of a series and number.

Quantitative records of the receipt, issuance and use of forms are kept in an electronic journal using automated information retrieval systems by the police officer, who is entrusted with the relevant duties.

${ }^{12}$ Krasnitskaya A. Legal documents: technique of drawing up, registration and editing: manual / A. Krasnitskaya. - 2nd view., please. Kyiv: parliamentary Publishing house, 2006. $537 \mathrm{p}$. 
On identification of the spoiled forms (mechanical damages, printing marriage) it is reported to the head of the corresponding division.

Spoiled, returned or having typographical defects, forms of protocols, resolutions and temporary permits are destroyed and written off according to the act of monthly write-off of blank products.

On the basis of the act of monthly write-off of blank products, data on their deregistration are entered in the electronic journal.

In case of detection of loss of forms of protocols, resolutions and temporary permissions the management of the corresponding division carries out office checks.

Administrative materials issued by the police, within a day are sent to the administrative practice units for their further registration and processing.

The person exercising control over the use of forms on an administrative offense and the resolution on an administrative offense, at the same time checks the legality of registration of administrative materials.

Temporarily seized documents be returned when there are grounds for a refund (court order, certificate of civil servants of the criminal-Executive inspection, the act-marked officials about elimination of the revealed violations and documents confirming the payment of the fine) by the authorized persons of the respective units of the patrol police in accordance with applicable law.

Documents that are the basis for the return of temporarily seized driver's licenses are entered into the automated information retrieval system by the authorized person of the patrol police unit.

Cases of violations of rules, norms and standards in the field of road safety are subject to storage for three years. Materials on violation of traffic rules, recorded with the help of photo, video or filming are stored in the unit in electronic form for three months from the date of fixing the violation.

Filling in the written form of protocols on administrative offenses, resolutions on bringing to administrative responsibility, temporary permissions is carried out in ink (paste) of black or blue color. Entries are made in legible handwriting, and the surname, name, patronymic of the person, brought to administrative responsibility, his place of residence (stay), place of work and position, special title, surname, name, patronymic of the police written in block letters.

The organization of control over the procedure for the implementation of proceedings in cases of administrative offenses in the police is carried out by their direct heads.

Control over compliance with the requirements for keeping a log of issuance of forms of protocols on administrative offenses, forms of resolutions on cases of administrative offenses and forms of protocols on 
administrative detention and their use is assigned to one of the Deputy heads of the police body, which is determined responsible in accordance with the order of the head of this body.

Direct control over observance by authorized officials of the legislation during implementation of proceedings on cases of administrative offenses is assigned to heads of structural divisions of body of police.

\section{CONCLUSIONS}

Authorized officials of the police shall carry out preparation of protocols on administrative offenses, protocols on administrative detention, and protocols on seizure of things and documents, protocols on inspection of things and personal inspection, as well as obtaining explanations from persons brought to administrative responsibility, victims, witnesses.

Administrative Protocol is a procedural document of different content and purpose, with the help of which an official or a representative of a public organization records the Commission of an administrative offense.

The Protocol on administrative offense is made on the special form which is made by the typographical method.

An administrative decision is a procedural document that is drawn up after consideration of a case of an administrative offense by a body or official. In the resolution state and justify the decision made during administrative proceedings.

Control over compliance with the requirements for keeping a $\log$ of issuance of forms of protocols on administrative offenses, forms of resolutions on cases of administrative offenses and forms of protocols on administrative detention and their use is assigned to one of the Deputy heads of the police body, which is determined responsible in accordance with the order of the head of this body.

\section{SUMMARY}

Hence, the administrative documents adopted in the process of performing activity on the basis and to execute laws of Ukraine unilateral power guidelines aimed at establishing, changing or terminating specific legal relations or such that are binding on subordinate bodies and officers of the internal Affairs rules (norms) with the purpose of the organization and practical realization of the rights of citizens and public order. They reflect the internal activities of the internal Affairs bodies on the organization, practical implementation of the protection of public order, public security.

Administrative acts are adopted in each individual case of application of administrative penalties to offenders. With their help, the sub-divisions of 
the internal Affairs bodies organize and send to the legal channel the behavior of persons who do not obey the law.

During the administrative review, in accordance with the current legislation, various documents are drawn up, which are divided into basic (mandatory) and auxiliary (optional).

The main (mandatory) documents include protocols (on administrative offense, on administrative detention of a person) and resolutions on administrative offenses. In these documents, a significant part of the work on the protection of public order is legally reflected. The procedure of preparation and registration of documents made by manufacture on Affairs about administrative offences are defined in the legislation of Ukraine on administrative offences, the Code of Ukraine about administrative offenses and the Instruction on registration of materials about administrative offenses, approved by Order of MIA of Ukraine № 185 dated 22.02.2001 of the year.

To auxiliary (optional) administrative documents which are made in each case separately concern: the statement, the report, the extract, the conclusion, the office letter, the reference and so forth. These types of documents contribute to the adoption of correct decisions by a collective body, official, public organization or public self-government body; ensure the rights of participants in the administrative process and contribute to the performance of their duties.

\section{REFERENCES}

1. Samples of civil legal documents: scientific and practical guide / ed. V. A. Kuznetsov. Kiev: Istina, 2017. 712 p.

2. Korzh A. Legal documentation. Kiev, 2011.

3. Krasnitskaya A. Procedural acts of criminal proceedings: legal technique, ways of improvement: abstract. dis. for the Sciences. the degree candidate. Yuri. sciences'. Kiev, 2008.

4. Krasnitskaya A. Improvement of the language of procedural acts of criminal proceedings. Ukrainian language in law: state, problems, prospects: collection of materials of Sciences. - pract. Conf. Kiev, 2016. P. 79-82.

5. Krasnitskaya A. Legal technique of procedural acts of criminal proceedings. Scientific Bulletin NADU. No. 2. 2003. P. 120-128.

6. Krasnitskaya A. Legal documents: technique of drawing up, registration and editing: manual / A. Krasnitskaya. - 2nd view., please. Kyiv: parliamentary Publishing house, 2006. 537 p.

7. Michurin E. Technique of drafting contracts: scientific and practical guide. A series of "Practice and law". Kharkov: Urxvt, 2017. 536 p.

8. Dutko A. General characteristics of the legal and technical normsetting. Herald of Lions. UN-Tu. 2000. Vol. 35. P. 48-51. 
9. Kashanina T. Legal technique: student. Moscow: Eksmo, 2011.

10. Krasnitskaya A. Rules, requirements of legal technique concerning the procedural acts of criminal proceedings. Jurisprudence: theory and practice. 2009. No. 1. P. 7-13.

11. Krasnitskaya A. Law enforcement errors in the texts of procedural acts of criminal proceedings. The court of appeal. 2016. No. 1. P. 28-33.

12. Krasnitskaya A. Problems of formation of definition of legal technique in post-Soviet times. Scientific Bulletin of KNUVD. 2010.

13. Rozhnova V. Workshop on the preparation of criminal procedural documents (pre-trial proceedings): studies. - pract. possib. with method. recom. Kiev: View. Palivoda A.V., 2009. 308 s.

14. Rona A. Collection of claims. practical guide. Kyiv: CST, 2017. $204 \mathrm{p}$.

15. Tertyshnyk V. Criminal procedure law of Ukraine: textbook. The 4th form., additional and pererab. K.: A. S. K. publishing House, 2017. 1120 p.

Information about the author: Predmestnikov O. G., Doctor of Law, Professor, First Deputy Head of the Main Territorial Department of Justice in the Kherson Region 42/14, Potiomkinska str., Kherson, 73040, Ukraine 


\section{INNOVATION POLICY AND PATENT STRATEGIES OF PHARMACEUTICAL COMPANIES ECONOMIC AND SOCIAL ASPECTS}

\section{Rachinska I. M.}

\section{INTRODUCTION}

The creation of innovative drugs is an expensive and complex process. Thus, according to the European Federation of Pharmaceutical Industries Associations (EFPIA), the average cost of developing a new drug is about $\$ 1.5$ billion. (1.2 billion euros), and the time from the beginning of the development of the drug to its entry into the market on average reaches 12-13 years. In addition, on average, out of 10,000 molecules that go through all stages of development, preclinical and clinical trials, only 1 or 2 active ingredients receive permission for commercial marketing as a drug.

The introduction of new medicines into circulation is controlled by the national administrative bodies responsible for the quality, efficiency and safety of medicines, the so-called pharmacological supervision bodies, which carry out the registration of the drug and confirm it with a special document. This registration is carried out on the basis of data confirming the clinical efficacy and safety of the drug, which takes an average of 8 to 10 years to obtain.

It should be noted that the permissive administrative procedure for commercial use is established by law not only for medicines but also for some other products: food and barberry additives, cosmetics, medicines for animals or veterinary biological products, plant protection products, agrochemicals, medical devices, etc. However, this monograph will consider only those provisions of legislation and procedures relating to medicines for humans.

The need for testing and registration of medicines leads to the fact that they enter the market, as a rule, after 5-10 years or more from the date of filing a patent application, the object of which is the drug. Thus, the actual use of such a patent is possible only after the registration of the drug by the pharmaceutical supervision authorities and before the expiration of its validity.

Based on a study of more than 300 types of medicines on the European market, EFPIA concluded that the effective monopolistic commercial use of a patented drug is on average about 8 years due to the length of the drug trials for its registration both in Europe and in other countries. 
In order to ensure that the patent holder can exercise monopoly rights in the pharmaceutical field during the period of validity of the patent, as is the case in other industries, the national patent laws of many countries have introduced a provision on the extension of the patent term, the object of which is the product. For the first time this provision on the extension of the patent term to 5 years was introduced in the patent laws of the United States in 1984, a Similar rule was introduced in 1987, the patent law of Japan.

In 1991, the European patent Convention (EPC) was supplemented by a new version of part 2 of article 63 of the EPC, according to which the powers of the holder were granted the right to continue the 20 -year term of the European patent or to provide appropriate protection after the end of this period on the same terms as apply to national patents:

a) in the event of a state of war or a similar emergency in that state;

b) if the subject matter of a European patent is a product or a method of manufacturing or using a product which, before being put into circulation, must undergo an administrative authorization procedure established by law.

That is, the EPC provided for two mechanisms for such a European patent to continue the effective monopoly commercial use of the patented drug: the first-by extending the 20-year term of the patent, the second-through the provision of appropriate protection after the expiration of this term.

In the EU member States, Council regulation (EEC) no 1768/92 on the introduction of the certificate of additional protection of medicines, adopted by the economic Commission for Europe on 18 June 1992, was developed for the harmonization and unification of national legislation in the field of legal protection of inventions, as well as to protect the interests of drug manufacturers. The Regulation introduced in all EU member States a special form of additional protection of medicines-complementary protection certificate, SPC.

The monograph uses the term certificate of additional protection because the certificate is a legal document that grants its owner the same rights as a patent for an invention, and has the same restrictions and obligations.

It should be noted that the world intellectual property organization standard ARTICLE 9 "recommendations on bibliographic data concerning patents and certificates of additional protection (SPC) and related, in the official translation into Russian as well as into Ukrainian, also uses the term "certificate of additional protection".

But the Legal dictionary gives the following definition of "certificate". Certificate (FR. certificate, from lat. Certified-certify) - the document certifying any fact (for example, quality of goods, navigation of the vessel, the medical certificate on vaccinations, etc.). That is the certificate certifies the fact but not the right. 
The purpose of this article is to study the legal regulation of the extension of the term of protection of medicines using the mechanism of extension of the patent, the object of which is the drug, that is, patent law and using a special form of additional protection of medicines - certificate of additional protection (CAP), coverage of the practice of these mechanisms in different countries of the world as well as regulatory and practice of extension of the patent for the invention in Ukraine.

\section{Patent protection of original medicines}

Patent protection of inventions performs a number of economic functions. The first, the most famous of them is the stimulating function. It is based on the assumption that in the absence of patent protection, inventors will not be able to receive income from their intellectual development, which in turn will lead to negative consequences in society as a whole. There will be less innovation than society desires. Therefore, society grants a timelimited monopoly on inventions, believing that the cost in the form of higher prices to consumers through the granting of a monopoly, will be overshadowed by the benefits of innovation.

The second function is the transaction function. The existence of patent protection is defined as a necessary precondition for the emergence of a market for technology and specialized technology suppliers. The existence of patent protection contributions to collaborative research are widely recognized as a contributing factor to collaborative innovation (for example, if a company licenses a patented invention to another firm that is better able to bring it to market) ${ }^{1}$.

In practice, the stimulating and transactional functions are mutually related. Patents can facilitate revenue sharing among those who contribute to this research process. This, in turn, affects the amount of incentives available to the next inventors. Obtaining patent rights can limit duplication of innovation efforts while maintaining, in some cases, sufficient incentives to further develop products under the control of the patent owner. A number of studies have shown that strong and broad patent protection, especially of early "early" research, can also deter subsequent improvements to the innovation of subsequent inventors, thus creating obstacles to technological progress.

The third function that patents perform is the disclosure function. Disclosure of technical information that would otherwise be kept secret is an important aspect of all research and development and acts as a compensation

\footnotetext{
${ }^{1}$ Worker L. the Problem of evergreen patents in Ukraine. Intellectual property in Ukraine. 2012. No. 8. P. 20-26.
} 
for legal protection in the agreement between the inventor and the society. It is indispensable that the information disclosed in the patent documentation should enable the invention to be reproduced by a person skilled in the art. In practice, this may require special skills, knowledge of production secrets (know-how) and additional technologies. Limitations in the process of studying patents and the quality of the information disclosed by the applicant may in some cases prevent the possibility of reproducing the invention.

The value of patents also lies in their fourth - signal function. Patent ownership can serve the purpose of signaling a firm's innovative capabilities and increasing its ability to raise non-negotiable capital, especially through venture capital financing. This function is particularly important in the biotechnology sector, where new firms rely on their protected intellectual capital to raise funds.

Intellectual property rights (IP) and wine patents interact in a complex way with policies in other areas, both nationally and internationally. Although the IP policy is national, it has an impact on the results that have been reflected in the Agreement on trade-related aspects of intellectual property rights (trips) and numerous other bilateral and multilateral agreements. At the national level, IP rights can be affected by policies in other areas, including competition, pharmaceutical pricing, government procurement and others.

The efficiency of the pharmaceutical industry not only at present, in the near future, but also in the long term depends to a large extent on the clarity and transparency of the mechanism, which ensures IP protection, on the perfection of the legal norms regulating this process. It is important to take into account that the terms for which this protection applies, is the very stumbling block around which real legal battles of the main players of the pharmaceutical market - manufacturers of medicines (hereinafter - drugs) often unfold ${ }^{2}$.

Originator companies focused on the production of brands that require the longest terms of protection of their products in order to recoup the costs of $\mathrm{R} \& \mathrm{D}$, reinvest in the replenishment of product lines, that is, to support the further development of their innovative developments. Generic companies, whose number and influence has increased significantly in recent years, are interested in reducing these terms, which gives its benefits "here and now" both to the companies themselves and to health care, since it allows covering this deficit with less expensive and more affordable.

${ }^{2}$ Androshchuk G. O. Innovative policy and strategy of pharmaceutical companies: aspects of intellectual property. Topical issues of IP: collection of reports of the XXI International scientific and practical conference (Yalta, September 16-18. 2016). Kyiv: Information systems. - 2017. C. $11-30$. 
The main way to ensure effective IP protection in all countries is still a patent certifying the priority of the developer and copy protection in the territory of the patent. Almost all objects related to the Molecular structure of active pharmaceutical ingredients (hereinafter - API) and auxiliary components, dosage form, production technology, etc. are subject to patent protection.

As a rule, the patent validity period in the USA and Europe is 20 years and can be extended for drugs up to 5 years in the European Union (in Ukraine, the maximum patent validity period is 25 years). This period allows the company-developer to get the maximum profit from the sales of the drug, because during this time it is a monopolist in the market. However, in most cases, the real terms of such a monopoly do not exceed 10-15 years, since the peak of activity on patenting drugs usually falls at the end of the first phase of clinical trials.

In order to overcome this problem and increase the period of monopoly stay on the market of their drugs, many originator companies use a variety of strategies for" greening «the product. "Evergreen patents" (from the English. evergreen - evergreen) - is an artificial extension of the property rights of intellectual property arising from the patent on the API by further patenting various additional properties of the API, methods of its production, pharmaceutical compositions, which include the API, as well as diagnostic, therapeutic and surgical methods of treatment of people or animals with the help of drugs containing the $\mathrm{API}^{3}$.

Taking advantage of the monopoly right to the product, which is guaranteed by patent law, development firms maintain sufficiently high prices for drugs. The price of a patented drug can be tens, hundreds of times higher than the cost of production because its price includes: the cost of development and clinical trials, training of doctors and pharmacists, the cost of experimental equipment, the cost of monitoring the effect of the drug in the initial stage of its promotion to the market and, importantly, the cost of marketing.

At the same time, only about $20 \%$ of the costs fall on the work related to the synthesis of a new drug, and $80 \%$ - on its subsequent experimental and clinical study. In order to find a new drug substance, according to various estimates, it is required to synthesize from 3 to 10 thousand new compounds. The development of a new drug is quite time-consuming and expensive process. The cost of creating one new drug reaches $\$ 800$ million. The United States, and in preclinical studies and clinical trials of the original

${ }^{3}$ Soulier D. and Day N. Using Patent Extension to make up for lost time. MIP. 2016. No. 240. P. 1-7. 
drug have on average 8.5 years. This explains the high price of original drugs, which is not reduced in roki2.

The pricing policy of the company-developer of the original drug is clear. Significant funds spent on the search for the API molecule, drug research, bringing it to market, careful monitoring of possible adverse effects and interactions, while patent protection continues to operate, may be irretrievably lost in a few years. A generic drug, which is often reproduced by several companies at the same time, "inherits" all the properties, costs of effort, time and money as the original drug.

A generic medicinal product, as defined by the world health organization, is a medicinal product that is used interchangeably in medical practice with an innovative patented (original) product manufactured, as a rule, without a license from the Creator company and is sold after the expiration of the patent or other exclusive rights.

When evaluating generic drugs should keep in mind the following. The generic contains the same active drug (substance) as the original (patented) drug. Generic differs from the original drug auxiliary substances (inactive ingredients, fillers, preservatives, dyes, etc.). Differences are observed in the technological process of generics production.

And though it may be argued that the original is always the original, and the reproduced medium is only the reproduced medium. The common international generic name makes these drugs similar to the consumer, and the generic, usually for a lower price, more attractive ${ }^{4}$.

Manufacturers of original pharmaceutical brands protect their exclusive rights mainly through patent law. The implementation of patent protection for a particular molecule underlying drugs, provides for a ban on its reproduction for a period of time, the duration of which is 20 years. It should be borne in mind that from the beginning of testing a new molecule and the moment of obtaining a patent to the appearance of drugs on the market can take $10-15$, or even more years. Thus, the manufacturer of the original drug has an average of up to 5 years to compensate for costs and receive dividends from the original drug. By the end of this period, as a rule, there are attempts, taking advantage of the peculiarities of patent legislation, to extend the term of patent protection.

According to the report of the European Commission in the period 2007-2017 the number of applications for pharmaceutical patents doubled, with $87 \%$ of them being secondary, that is, not for the active substance itself, but for the method of its production, the dosage form and composition of the

\footnotetext{
${ }^{4}$ Financial Management in the NHS: Report on the NHS Summarized Accounts 2007-08. Twenty-second Report of Session 2008-09. URL: www.publications.parliament.uk.
} 
corresponding drugs, etc. This creates serious difficulties when creating generic versions.

The market entry of many generic drugs was deliberately delayed for 7 months or more, costing Europe 3 billion Euros. The reason for this were: patent clusters (each drug can be protected by dozens of patent families), through which the EU suspended the consideration of approximately 1300 applications for marketing permits for generics; litigation with generic companies initiated by originators; bilateral agreements between generic and innovative companies to delay the withdrawal of generics to markets; patent management during the life cycle of drugs; interference with the obtaining of marketing authorizations by e-companies ${ }^{5}$.

For example, in 1978, the main patent was obtained for the molecule omeprazole, starting from the late 90 -ies - for the magnesium salt of omeprazole, a method for treating diseases of the gastrointestinal tract using the levorotatory isomers of omeprazole, The s-enantiomer of the magnesium salt of these drugs in the form of trihydrate, a new crystalline form of omeprazole. Each of these patents allowed the developer to fight attempts to market generic omeprazole.

A similar situation has developed in Ukraine, where the Swedish firm ASTRA AB has filed the following applications for a patent of Ukraine. The essence of patent protection, which allows the patent owner to monopolize the use of its technical solution, thereby providing compensation for investments invested in it, quite accurately formulated $\mathrm{j}$. Robinson: "by slowing the spread of technological advances, patents create the conditions for the most significant advances to spread." Thus, the patent monopoly is an incentive for innovation. However, upon expiration of the patent, any pharmaceutical company, acquiring the right to produce its own version of the original drug, can create a generic drug.

\section{Strategies of pharmaceutical companies in connection with the end of patent protection of medicines}

For many years, the largest pharmaceutical companies, representatives of the so-called Big Pharma (Big Pharma), worked to prevent competition from representatives of the generic business-lobbied for the adoption of legislation that would extend the term of the patent monopoly, challenged in the courts the right to produce generic versions of original drugs, conducted thousands of clinical trials in the hope of patenting another way of using drugs, etc.

${ }^{5}$ IP Protection Incentivizes Innovation and Creates Jobs: A Message Worth Repeating. D. Kristina Lybecker, June 8, 2015. URL: www.ipwatchdog.com/.../ip-protection -incentive. 
However, now many of the representatives of Big Pharma are in such a situation that they are forced to join the number of those who were opposed all this time. Faced with the problem of completing the term of the patent monopoly on their original drugs, representatives of Big Pharma are increasingly inclined to the hybrid brand / generic model of their activities.

Four of the five largest multinational pharmaceutical corporations in the world ("Pfizer Inc.", "GlaxoSmithKline plc.", "Sanofi-Aventis" and "Novartis International AG") began to actively take a position in the generic business. Their example was followed by other major players in the pharmaceutical market. In 2009, Pfizer announced that it was expanding its generic drug product portfolio through two deals with companies based in India ${ }^{6}$.

Pfizer has expanded its agreement with Eurobond Pharma India to license the commercial rights to 60 generic drugs for more than 70 countries, in addition to the 70 drugs for which the original agreement was concluded. Pfizer also announced an agreement with another Indian company, Claris Lifesciences Limited, which includes 15 generic parenteral drugs that Pfizer will market in the United States, Europe and Australia under its own trademarks.

The company plans to expand the range of generic drugs through licensing deals, acquisitions and in-house developments. The market for generic drugs is huge, growing faster than it may seem at first glance, and that is why Pfizer is making efforts to "grow" this subsection. In addition to India, the company relies on the markets of countries such as China, Brazil, Mexico, Russia, Turkey and the middle East. Annual sales in these markets are expected to generate an additional \$ 3 billion. USA. And the middle East is called one of the most promising regions for sales growth.

Novartis has announced that it is ready to pay 925 million Euros (1.294 billion dollars).) for the portfolio of parenteral generic drugs of the Oncology division of the Austrian company "Ebewe Pharma", which specializes in anti-cancer drugs such as carboplatin, cisplatin, doxorubicin and epirubicin. This company already has extensive business experience in the generic market. So, since 2003 it has its own generic division "Sandoz". Since then, other generic firms have been merged under this brand, including Canada's Sabex Holdings Ltd."(September 2004. the transaction price) of \$ 565 million.), Denmark's Durascan (July 2004; valued at \$ 25 million in 2003), Germany's Hexal AG (which is also a key player in the market for

\footnotetext{
${ }^{6}$ Worker L. the Problem of evergreen patents in Ukraine. Intellectual property in Ukraine. 2012. No. 8. P. 20-26.
} 
similar bio preparations) and the us' Eon Labs (the latter both) in June 2005; the deal is valued at $\$ 7.4$ billion $)^{7}$.

As for Sanofi-aventis, the company is particularly active in acquisitions in the generic business. It took over the Czech company "Zentiva" (the deal is valued at 2.34 billion dollars.), which occupies a strong position in Eastern Europe and Russia. Then "Sanofi-aventis" acquired two more companies: a private Mexican firm

"Kendrick Farmaceutica "(the amount of the transaction was not disclosed) and the Brazilian "Medley Pharmaceuticals Ltd." (the deal is valued at \$ 688 million.).

The next company to expand its presence on a multinational scale is GlaxoSmithKline, which in 2009 took care of $16 \%$ of Africa's largest generic company Aspen Pharmacare (a deal valued at \$ 410 million). USA.) These companies have also expanded their strategic partnership, including the acquisition in 2008 of Aspen Pharmacare rights to 20 generic drugs that

Since 2010, GlaxoSmithKline has been marketing under its own brand names in 95 emerging markets, including China and India. In addition, the British pharmaceutical giant has signed an agreement with the American "Prasco Laboratories" that dose-recovery and provide marketing and distribution of many generic drugs "GlaxoSmithKline" in the United States.

Recently, the British company announced an agreement with the Indian generic manufacturer "D Reddy's". Through this deal, GlaxoSmithKline gains access to Reddy's now existing product portfolio, as well as products that will appear in the future, all to more than 100 drugs from the group of antidiabetic, cardiovascular, gastroenterological, painkillers and Oncology products that will market in markets that are developing outside India. The Swiss company "Roche" acquired the American biotechnology company Genentech "(the deal is estimated at 46.8 billion dollars) ${ }^{8}$.

The Company "Merck \& Co." entered the market segment of generic drugs by establishing a new division. "Merck BioVentures", which will focus on similar biological products (biogenerics). The company expects to get at least 5 other generic bio preparations in its bio-product portfolio. In order to help yourself gain a foothold in this growing sector, Merck \& Co. "announced that it plans to buy a portfolio of similar biopharmaceutical products of the American company "Insmed Inc." together with its production facilities located in boulder, Colorado (the deal is valued at \$130 million).

\footnotetext{
${ }^{7}$ Financial Management in the NHS: Report on the NHS Summarized Accounts 2007-08. Twenty-second Report of Session 2008-09. URL: www.publications.parliament.uk.

${ }^{8}$ Worker L. the Problem of evergreen patents in Ukraine. Intellectual property in Ukraine. 2012. No. 8. Pp. 20-26.
} 
The company's product portfolio includes two products that affect the granulocyte colony stimulating factor (gra - nulocyte-colony stimulating factor), which are currently undergoing phase III and phase I clinical trials, respectively. "Merck \& Co. "Also, the presence of its generics in the market of Japan, where its subsidiary "Banyu Pharmaceutical Co." is stationed. Ltd.", which signed an agreement with "Mylan Inc." to promote two key generic cardiovascular drugs in the Japanese market.

Active positions are also occupied by Japanese companies. Thus, "Daiichi Sankyo" completed the acquisition of the Indian "Ranbaxy Laboratories Limited", investing in it a total of $\$ 4.6$ billion. I suggested-Shi create a hybrid brand-generic business (although subsequent problems in production and the introduction of stricter standards of drug approval by regulators led to a record for "Ranbaxy" losses amounted to 335.8 billion Japanese yen, or $\$ 3.5$ billion $)^{9}$.

However, not all companies leave their original drugs in a helpless state. Thus, Pfizer applied an original way to maintain the image of brands, starting to implement in the United States the program "MAINTAIN" ("Support") to provide free access to more than 70 drugs of its own production for those who lost health insurance as a result of job cuts. Free treatment with original drugs will be available - but for 1 year or until the one that became unemployed again received an insurance policy So Pfizer is trying to support not only the market of its shares, but also encourages patients to take original drugs rather than switch to their generic versions as a way to save money.

The most important problem facing all large representatives of Big Pharma is the end of the patent monopoly. In the next 4 years, the patent monopoly will expire with approximately 70 original products. For example, the Corporation "Pfizer" is a number of products, including mega blockbuster, the drug Lipitor / atorvastatin (atorvastatin), used in hypercholesterolemia. According to some estimates, Sanofi - Aventis drugs, which account for more than $20 \%$ of all sales of this company in the us pharmaceutical market, are soon facing competition from generics, including products such as Plavix/plavix (clopidogrel; marketing together with Bristol - Myers Squibb), Eloxatin / Oxol (oxaliplatin) and Taxotere / TaxoTer ${ }^{\circledR}(\text { docetaxel })^{10}$.

${ }^{9}$ Androshchuk G. O. Intellectual property, innovations, economic development: optimal ratio. Intellectual property in Ukraine. 2016. No. 3. Pp. 4-7.

${ }^{10}$ IP Protection Incentivizes Innovation and Creates Jobs: A Message Worth Repeating. D. Kristina Lybecker, June 8, 2015. URL: www.ipwatchdog.com/.../ip-protection -incentive. 
Lost patent protection back in 2012; several other drugs are also on the verge of ending patent protection.

The drug company "Merck \& Co." Cozaar (losartan) was faced with the need to resist competition from gene-RICS in 2010.

However, the end of the patent monopoly is only the tip of a growing generic iceberg. According to experts, the global market for generic drugs is growing by about $10-15 \%$ per year, and its growth will continue for several more years, especially in the United States. With the coming to power in the United States, the government of Barack Obama and the Democrats, who form a majority in both houses of Congress, increased political support for the generic drug market. As price sensitivity increases in the pharmaceutical market, health care reform is expected: Americans are becoming more inclined to buy cheaper generic preparation6.

An increase in the generic drug market is also expected in Japan. Thus, over the past 3-4 years, its volume in the land of the Rising Sun has increased by about $7 \%$ per year, and the government is taking steps to further increase it to $30 \%$ in 2012 (Schofield I., 2009). The favorable situation in the Japanese market is already attracting foreign companies. Thus, "Teva Pharmaceutical Industries Ltd." established a joint venture (equally owned venture) with local" Kowa Pharmaceutical Company Ltd.", and the Icelandic "Actavis" with "Aska Phar-maceutical" organized in 2008 a joint venture "Actavis ASKA Co. Ltd."

In Europe, price pressures have encouraged most national governments to support the consumption of generic drugs in order to reduce rising health costs. Thus, according to the report of the national audit office of Great Britain (National Audit Office) in 2008, the National health service (National Health Serve - ice) managed to save almost 400 million pounds (657.3 million dollars).) Through the use in the health care system of cheaper generic drugs, especially the therapeutic group statins ${ }^{11}$.

At the level of the European Union as a green light generics acted dual system of approval of generic drugs: on the one hand, was introduced decentralized, and on the other - centralized procedural.

Their approval, which provides generic drugs with access to all EU markets. Legislation on similar biological products has also been developed in Europe. That is why, in this context, "Merck \& Co." steps towards similar biopharmaceutical products are not without meaning. European experience has shown that the market for similar biological products has potential, and the legislation for the approval of these drugs in the United States is very similar to the European path.

${ }^{11}$ Soulier D. and Day N. Using Patent Extension to make up for lost time. MIP. 2016. No. 240. P. 1-7. 
Another factor that stimulates the reorientation of representatives of Big Pharma to generics is the significant growth of emerging markets, which make up most of the business of multinational pharmaceutical companies in Asia. The importance of pharmaceutical markets of countries that are developing for Big Pharma will continue to grow, and global strategies for their development will increasingly take into account both the medical needs and commercial opportunities of such countries.

According to experts, the volume of 10 major emerging markets will grow to $\$ 168$ billion by 2015 . compared to $\$ 67$ billion. in 2005 , the Reason for this is the increase in the number of middle-class people in these countries who need better drugs and medical care, as well as the increase in the number of chronic diseases, especially cardiovascular diseases.

Total sales growth in emerging markets, including Central and South America, Africa and much of Eastern Europe and Asia, more than doubled, and the population of developing countries reached 5 billion people by 2015 . At GlaxoSmithKline alone, sales in these markets reached 2.3 billion pounds (\$3.75 billion) last year.), an increase of $12 \%$.

The head of the R \& D division of "AstraZeneca" in the Asia-Pacific region and Japan, Patrick Keohane (Patrick Keohane), noted that sales of the company's products in emerging markets last year reached 4.27 billion dollars. their growth was $16 \%$. However, in China, for example, only $\$ 8$ a year is allocated to health care per capita., So the company had to look for an answer to the question: how best to meet the medical needs of such markets, which could not but affect the R \& D strategy.

At present, AstraZeneca's strategic efforts to enter the market of biological products have come to the fore, and such products account for about a quarter of the new drugs in the company's portfolio.

AstraZeneca will continue its steps towards development bioproducts, made possible by the acquisition of MedImmune Inc."12.

While Asian and other markets in developing countries may provide opportunities for Big Pharma to grow, issues such as IP protection, parallel imports and counterfeit drugs still cause transnational corporations serious problems.

Representatives of Big Pharma are betting on the generic market, considering a hybrid brand-generic strategy as a way to optimize, pushed to this by economic and regulatory conditions. But will such a strategy work? Most large multinational corporations believe that Yes, and have already taken the appropriate decision.

12 Androshchuk G. O. Ukraine in The global index of intellectual property. Intellectual property in Ukraine. 2017. No. 12. P. 60. 
Other companies, whose products will face the end of the patent monopoly after some time, may soon adopt the same strategy of reorientation to the generic business. Thus, AstraZeneca's drugs, such as Arimidex/arimidex (anastrozole), Symbicort/Symbicort Turbuhaler (budesonid + formoterol) and Seroquel/Seroquel TM (quetiapine), will face generic competition in the next two years, although the company has not yet made steps towards the generic market.

However, not everyone will choose the strategy of generic drugs. Companies whose business is based on R \& D and which have not yet been affected by the issue of ending patent exclusivity are unlikely to follow this strategy. So "Roche", "Bayer Schering Pharma" and "Abbott Laboratories Inc." only partially subjected to competition from generics. A few years ago, Roche said it was not interested in generic drugs because not many products would lose their patent monopoly in the near future ${ }^{13}$.

This may change, and as the generic drug market continues to grow, generic companies will occupy an increasing share of the major pharmaceutical markets. Thus, "Teva" begins to expand into the Japanese market, "Mylan" strengthens its position in India and in the Eastern European generic markets. "Lupin Pharmaceuticals Inc." Indian company acquired $51 \%$ of HP "Multicare Pharmaceuticals Philippines Inc." and is looking for opportunities to grow its business in Asia, Eastern Europe and Latin America.

Who can $\mathrm{R} \& \mathrm{D}$ companies that plan to enter the generic drug market rely on? One of the targets is Ratiopharm, the No. 1 generic company in Germany, up for sale. No specific buyer has yet been announced, although many bidders have been named, including Sanofiaventis and Teva, and later, according to Bloomberg reports, investment groups Apax Partners and Warburg Pincus.

Another possible target is the Icelandic company "Actavis Group", which brought to the market of Germany, Ireland and the Netherlands a generic version of pantoprazole, after the patent monopoly on the original drug Protonix Company "Wyeth" ended. However, the reorientation of Big Pharma to the generic market does not end there. The opposite process is predicted, when the largest representatives of the generic business will take over R \& D companies.

${ }^{13}$ Androshchuk G. O. Innovative policy and strategy of pharmaceutical companies: aspects of intellectual property. Topical issues of IP: collection of reports of the XXI International scientific and practical conference (Yalta, September 16-18. 2016). Kyiv: Information systems. -2017 . C. $11-30$. 
Only companies - leaders of the generic sector of the market, which are called "young wolves", manage to break through the patent protection of Big Pharma. Like innovative companies, these companies have their product lines of generic drugs in various stages of readiness for placement on the market. This requires constant analysis of the patent portfolio of originators, which allows to identify "weaknesses" or "workarounds" that can be overcome in the development of generics. Not every company can afford to participate in lawsuits defending the right to bring generics to the market. It is reported that the average cost of court costs in such cases is $\$ 2$ million. USA.

The analysis, monitoring and application of patent information requires the participation of consultants with specialized training. After all, a patent for a molecule of an active substance is only the tip of the iceberg of protection of the original drug. Interesting facts about drugs and IP on the example of the original drug atorvastatin report specialists "Generics Web Pty Ltd" - Australian firm of patent analysis and search.

On the EU market (in the UK) Lipitor was first introduced in 1996, and the validity of the patent for API ends in 2011 there Are about 230 families of patents relating to drugs atorvastatin, namely the molecule of the active substance, the composition of drugs, the production process, application, etc. Only $80 \%$ of them mention atorvastatin. There are more than 120 owners of the relevant patents, some of them are generic companies that develop the drug atorvastatin in such a way as not to infringe on the IP of Big Pharma. Among them, the leaders are "Biocon" (API), "Teva "(API and drug), "Lek". The main emphasis in the development is on the use of amorphous, not crystalline atorvastatin, and the activity of obtaining patents in the last 5-6 years has increased significantly. That is, the concept of development of generic drugs in compliance with IP rights is not something symbolic and abstract ${ }^{14}$.

By obtaining patents relating to original drugs, within 2-3 years after their introduction to the market, the leaders of the generic industry contribute to the intellectual sphere. The first generic drug on the market in the United States becomes the subject of $50-80 \%$ of all prescriptions within 10 weeks after its introduction. The share of the market, which is occupied by the pioneer generator, in monetary terms is approximately $57.6 \%$. At the same time, the retail price of the drug is lower than the original by about $40.8 \%$.

${ }^{14}$ IP Protection Incentivizes Innovation and Creates Jobs: A Message Worth Repeating. D. Kristina Lybecker, June 8, 2015. URL: www.ipwatchdog.com/.../ip-protection -incentive. 


\section{Pharmaceutical market and patent protection of medicines in Ukraine}

The pharmaceutical industry is a high-tech industry with a high level of intensity of research and development (science intensity) and is one of the most profitable in the world. As noted in the explanatory note to the resolution of the Verkhovna Rada of Ukraine "on holding parliamentary hearings on the topic" on the current state and prospects of development of the pharmaceutical industry of Ukraine "the high-level discussion of the current state and prospects of development of the pharmaceutical industry is caused by serious threats associated with the further functioning of this very important branch of the national economy, taking into account global trends.

Despite a certain increase in production and sales of pharmaceutical products, domestic manufacturers continue to lose ground not only in foreign but also domestic markets. According to the results of 2010, the products of 470 foreign and only 150 Ukrainian (that is, in three smaller numbers) pharmaceutical companies were presented in Ukraine. According to the Antimonopoly Committee of Ukraine, 10 Ukrainian and 10 European companies control half of the market ${ }^{15}$.

Of the 18 thousand registered names of drugs in Ukraine produced only 5.5 thousand. Drugs of foreign origin account for more than $76 \%$ of the total market. More than $90 \%$ of medicines are technologically obsolete, which have already expired 20-year term of patent protection. The production of modern drugs requires increasing investment in research activities (from 800 million to 1 billion dollars). The United States for a drug), which is unaffordable for domestic producers. This, in turn, will continue to reduce them. Competitiveness, and after a certain time can lead to mass bankruptcy of enterprises in the industry.

According to statistics, citizens of Ukraine annually spend 32 billion UAH on medicines., which accounts for $90 \%$ of all drug costs in the country. The state assumes only $10 \%$ or 4 billion in recent years in Ukraine there is a tendency to reduce the level of consumption of drugs in kind. However, the level of consumption of drugs per capita in monetary terms has doubled from $\$ 27$ to $\$ 54$, and in 2013 this figure reached $\$ 80$.

Ukraine ranks 4 th in terms of drug costs per capita among the CIS countries (after Russia, Belarus and Kazakhstan). In the EU, this figure is much higher, the level of spending on drugs per capita in the Czech Republic is $\$ 331$, Slovakia $-\$ 254$, Poland - \$154. The reason for this situation-low purchasing power of citizens of Ukraine, as well as low social protection of

\footnotetext{
${ }^{15}$ Financial Management in the NHS: Report on the NHS Summarized Accounts 2007-08. Twenty-second Report of Session 2008-09. URL: www.publications.parliament.uk.
} 
the population in the field of drugs. The domestic system of pharmaceutical support is based on the vast majority of drugs in conditions of extremely limited budget funds. Thus, at present, the country cannot provide drugs even preferential categories of the population ${ }^{16}$.

A significant decrease in the availability of treatment to citizens of Ukraine is caused by the increase in prices for paid treatment and drugs, which has been particularly noticeable over the past 3-4 years. Thus, in 2009 the cost of official paid medical services increased by 20\%, in 2010-by another $10 \%$. The official rise in the price of medicines in 2009 amounted to more than $40 \%$, in 2010 medicines rose by another 6-10\%. The increase in prices for medicines has been lasting for a long time and in 2011.currently, there is a large gap between the ability of society to Finance health care costs and the ever-increasing need to increase them. In Ukraine, up to $25 \%$ of all expenditures in the health care system are related to drug provision. At the same time, the return on investment remains low: there is no increase in life expectancy, reduction in mortality and the number of serious complications.

According to the results of the first half of 2013, the volume of pharmacy sales of drugs in the country amounted to UAH 14.6 billion for 625 million packages, which is $15.7 \%$ in cash and $3.8 \%$ in kind more than last year. In physical terms, that is, in packages, the majority of drugs sold (65.4\%) were of domestic production. At the same time, in monetary terms, the situation is the opposite: Ukrainian consumers paid $68.6 \%$ for imported medicines, while domestic consumers paid $31.4 \%$ of the total amount spent on medicines.

The volume of the pharmaceutical market of Ukraine in 2013 amounted to 36 billion UAH., which is a record of the last six years. On the territory of Ukraine there are more than 100 pharmaceutical enterprises that produce their products according to European standards, a developed network of 20 thousand pharmacies and $\$ 120$ million of investments in the pharmaceutical industry in 2013.

Despite the rather dynamic pace of development in comparison with other sectors of the economy, the pharmaceutical industry of Ukraine has a number of serious problems. One of them is imperfection of the legislative base in the sphere of circulation of drugs, which leads to: containment of development and introduction in manufacture of generic drugs, the creation of unequal conditions of access to the market of drugs of domestic and foreign production, reducing the effectiveness of measures to counter

${ }^{16}$ Androshchuk G. O. Ukraine in The global index of intellectual property. Intellectual property in Ukraine. 2017. No. 12. P. 60. 
production and trafficking of counterfeit drugs, IP infringement in the sphere of circulation of medicines.

Over the past 5 years in Ukraine, the total number of applications for inventions under the national procedure has increased more than 2 times. At the moment, 14205 drugs are registered in Ukraine, which cover all pharmacological groups. Of them: 3719-HP domestic and 10486-foreign production. The highest growth rates (2.6 times) in the context of industries demonstrates the division "Medicines for therapeutic, dental or hygienic purposes". The most active filing of applications for inventions is recorded in such industries as medical technology, measurement and pharmaceuticals. At the same time, there is an active patent expansion of foreign pharmaceutical campaigns: out of the total number of foreign applications for inventions and utility models filed during 2004-2008 in Ukraine, drugs account for $22 \%$, while among national applications-only $6 \%$. With 510 patents for inventions issued in 2008 (according to the IPC class A61 medicine or veterinary medicine; hygiene), 328 (64\%) belong to foreign applicants and $182(36 \%)$ - to national applicants ${ }^{17}$.

Of all drugs currently available on the Ukrainian market, and which are considered the most promising, all are patented, which may limit the use of more affordable generics. These are patents on the molecule itself (e.g. raltegravir), a continuation of the original patent for 5 years after the expiration of the 20-year term (e.g. efavirenz) or patents on a combination of old molecules (e.g. TDF / FTC or LPV/r).

Of the drugs that are not yet used, but in the near future can be registered, many are protected by patents for inventions on the molecule (eg. rlpr, etravirine, fosamprenavir, maraviroc, coblt) or patents that justify the improvement of the original composition (eg. patent for atazanavir bisulfate, manufacture of darunavir intermediates, improved pharmacokinetics of elvitagravir in combination with RTV).

However, it is noted that the vast majority of drugs are not protected by patents and are for use in the public domain. So only $25 \%$ antivirus drugs for the treatment of hepatitis / AIDS remain patented.

It should be noted that, according to WIPO, applications for inventions in the pharmaceutical industry have steadily declined since 2007. In the history of the global pharmaceutical industry, 2012 will go down as a year of patent collapse-patent protection lost more than 40 brands with annual sales of about $\$ 35$ billion. USA. According to expert estimates, by 2015 the patent

${ }^{17}$ Worker L. the Problem of evergreen patents in Ukraine. Intellectual property in Ukraine. 2012. No. 8. P. 20-26. 
protection will lose drugs-blockbusters, the total annual sales of which is 150 billion dollars ${ }^{18}$.

From an economic point of view, the strengthening of IP protection leads to two contradictory results: the patent holder is granted a monopoly right for a certain period, which leads to a weakening of competition and an increase in prices in the market for the sale of patented products. Strengthening patent protection increases incentives for innovation by generating monopoly profits that offset the costs of research and development. Increased incentives provide long-term strategic benefits: improved technology and improved product quality.

\section{CONCLUSIONS}

The introduction of new medicines into circulation is controlled by the national administrative bodies responsible for the quality, efficiency and safety of medicines, the so-called pharmacological supervision bodies, which carry out the registration of the drug and confirm it with a special document. This registration is carried out on the basis of data confirming the clinical efficacy and safety of the drug.

It should be noted that the permissive administrative procedure for commercial use is established by law not only for medicines but also for some other products: food and barberry additives, cosmetics, medicines for animals or veterinary biological products, plant protection products, agrochemicals, medical devices, etc. However, this monograph will consider only those provisions of legislation and procedures relating to medicines for humans.

Despite the rather dynamic pace of development in comparison with other sectors of the economy, the pharmaceutical industry of Ukraine has a number of serious problems. One of them is imperfection of the legislative base in the sphere of circulation of drugs, which leads to: containment of development and introduction in manufacture of generic drugs, the creation of unequal conditions of access to the market of drugs of domestic and foreign production, reducing the effectiveness of measures to counter production and trafficking of counterfeit drugs, IP infringement in the sphere of circulation of medicines.

Over the past 5 years in Ukraine, the total number of applications for inventions under the national procedure has increased more than 2 times. At the moment, 14205 drugs are registered in Ukraine, which cover all pharmacological groups.

${ }^{18}$ IP Protection Incentivizes Innovation and Creates Jobs: A Message Worth Repeating. D. Kristina Lybecker, June 8, 2015. URL: www.ipwatchdog.com/.../ip-protection -incentive. 


\section{SUMMARY}

Countries that have strengthened the IP legal protection regime provide strategic advantages and benefits. However, for the transition economies, which include Ukraine, the economic situation will be different.

This is due to a number of reasons:

1) Ukraine is mainly a user, not an exporter of innovative products, and therefore does not receive the monopoly profits created by patent protection. Domestic consumers (patients) suffer losses as a result of price increases.

2) since the drug market in our country is relatively small in relation to global demand, the measures taken by Ukraine to strengthen the protection of patents practically do not affect the incentives for additional research.

This is due to the difference between the cost of generic drugs supplied by manufacturers in developing countries and the price of drugs in industrialized countries.

\section{REFERENCES}

1. Soulier D. and Day N. Using Patent Extension to make up for lost time. MIP. 2016. No. 240. P. 1-7.

2. Worker L. the Problem of evergreen patents in Ukraine. Intellectual property in Ukraine. 2012. No. 8. P. 20-26.

3. IP Protection Incentivizes Innovation and Creates Jobs: A Message Worth Repeating. D Kristina Lybecker, June 8, $2015 . \quad$ URL: www.ipwatchdog.com/.../ip-protection -incentive.

4. Androshchuk G. O. Innovative policy and strategy of pharmaceutical companies: aspects of intellectual property. Topical issues of IP: collection of reports of the XXI International scientific and practical conference (Yalta, September 16-18. 2016). Kyiv: Information systems. 2017. C. 11-30.

5. Financial Management in the NHS: Report on the NHS Summarized Accounts 2007-08. Twenty-second Report of Session 2008-09. URL: www.publications.parliament.uk.

6. Androshchuk G. O. Intellectual property, innovations, economic development: optimal ratio. Intellectual property in Ukraine. 2016. No. 3. P. 4-7.

7. Androshchuk G. O. Ukraine in The global index of intellectual property. Intellectual property in Ukraine. 2017. No. 12. P. 60.

\section{Information about the author:}

Rachinska I. M.,

Candidate of Law, Associate Professor, Associate Professor at the Department of Administrative,

Criminal Law and Procedure, International University of Business and Law 37-A, 49 HGD str., Kherson, 73040, Ukraine 


\section{APPEAL PROCEEDINGS}

Voronin Ya. G.

\section{INTRODUCTION}

One of the generally recognized international and European legal standards is the possibility of any person convicted of a crime to file a complaint with the Supreme court with the requirement to review the judgment. This standard is enshrined in the domestic legislation. Part 4 of article 125 of the Constitution of Ukraine provides that in accordance with the law in Ukraine there are local and appellate courts, and the provision of appeal and cassation appeal of the court decision referred to the basic principles of criminal justice (part 3, paragraph 8 of article 129 of the Constitution of Ukraine)

By ensuring that the tasks of criminal proceedings are carried out, the higher courts verify the legality and validity of the sentences and rulings handed down by the court of first instance. Under the new code of criminal procedure of Ukraine, there are four types of judicial review: appeal proceedings; cassation proceedings; proceedings on newly discovered circumstances; proceedings in the Supreme Court of Ukraine.

All four types of judicial review are an integral part of the criminal process, each of them is an independent stage.

\section{General characteristics of the appeal proceedings. Courts of appeal}

The difference between the previously existing cassation and the now fixed appeal.

Appeal proceedings - a stage of civil proceedings to review decisions (definitions) of the court of first instance, which have not entered into force, which occurs at the initiative of interested persons. The introduction of an appeal in civil proceedings is the implementation of the constitutional provision (article 129 of the Constitution of Ukraine) to ensure the appeal and cassation appeal of court decisions except in cases established by law.

Review of court decisions on appeal is the competence of the court of second instance (court of appeal).

Analysis of Chapter 1 of Section $\mathrm{V}$ of the code of civil procedure of Ukraine gives grounds to determine the following characteristics of the Institute of appeal: the appeal filed on the decision (ruling) of the court of first instance, not entered into force; the appeal due to the imposition, in the opinion of the person concerned, the illegal and (or) unjustified court 
decisions (rulings); the decision of the court of first instance depending on the will of the person who submits the appeal is being appealed in full or partially; the proceedings in the court of appeal is filed within certain appeal framework. When considering the case on appeal, the court of appeal checks the legality and validity of decisions of the court of first instance within the arguments of the appeal and the requirements stated in the court of first instance (article 303 of the CPC of Ukraine); the decision or determination, completed appellate review, shall enter into force from the moment of their proclamation $^{1}$.

The powers of the court of appeal allow it to examine evidence that the court of first instance has examined in violation of the established procedure or the study of which was wrongfully refused, as well as new evidence, the failure to submit to the court of first instance was due to valid reasons.

It is important to note that the court of appeal is not limited to the arguments of the appeal (that is, the limits of appeal are expanded), if the case will be found improper application of substantive law or violation of procedural law, which is a mandatory basis for the cancellation of the decision.

Also, if beyond the attention of the arguments of the appeal there was an obvious illegality or groundlessness of the decision of the court of first instance in cases of special proceedings, the court of appeal checks the case in full.

According to article 26 of the Law of Ukraine "on the judicial system and status of judges" in the system of courts of General jurisdiction there are appellate courts as courts of appeal for consideration of civil and criminal, economic, administrative cases, cases of administrative offenses.

Appellate courts review civil, criminal cases and cases on administrative offences are: the courts of appeal of oblasts, courts of appeal of the cities of Kiev and Sevastopol, Appeal court of the Autonomous Republic of Crimea.

According to Art. 291 of the civil procedure code of Ukraine, the appellate instance in civil cases is the judicial chambers in civil cases of the appellate General courts, within the territorial jurisdiction of which there is a local court, which adopted the appealed court decision ${ }^{2}$.

Previously, the current civil procedure legislation provided for a different method of appeal and verification of court decisions and rulings that have not entered into force-the cassation procedure. The cassation appeal that has

\footnotetext{
${ }^{1}$ Yasinok M., Kroitor V. principles of oral, immediacy and continuity in civil proceedings: monograph. Kharkov.: Espada, 2007. 152 p.

${ }^{2}$ Stefan O. Claim proceedings in cases of copyright and related legal relations in civil proceedings of Ukraine. Kiev, 2003. 236 p.
} 
been filed by the person concerned, was only a starting point for the court of cassation, as in the proceedings in cassation court also reviewed the legality and validity of decisions of the court of first instance in the part which was contested by, and in part that is not disputed and in respect of persons who have not filed a complaint. The court was not bound by the arguments of the cassation appeal and is obliged to check the case in full. This is the main difference between the previously existing cassation from the current appeal, given that at present the civil procedural legislation enshrines a rule that limits the powers of the court of appeal beyond the requirements of the appeal. This approach has its origins in Ancient Rome: "tantum devolutum qantum appellatum" - how many complaints, so much decisions.

\section{Right of appeal. Terms of appeal. Form and content of the appeal. Procedure for filing an appeal}

The parties and other persons who participated in the case, as well as persons who did not participate in the case, have the right to appeal against court decisions, if the court has decided on their rights and obligations. These persons may appeal the decision of the court of first instance in whole or in part (article 292 of the civil procedure code of Ukraine).

The subjects having the right of appeal, first of all, are the parties-the plaintiff and the defendant, since the decision on the case affects primarily their rights and interests. However, if in the court of first instance, the plaintiff is always an active party, as directly on his application, the proceedings are opened, then in the appellate instance, the initiative of the appellate proceedings may belong to the defendant, in the case when he does not agree with the decision and wants it reviewed by a higher court ${ }^{3}$.

The right of appeal is also enjoyed by the co-defendants and codefendants, who may appeal to the court of appeal both jointly and separately from each other.

Other subjects of appeal may be third parties who claim independent claims on the subject of the dispute, and third parties who do not claim independent claims on the subject of the dispute.

Despite the fact that a third party with independent claims has its own purpose in the case, puts forward its own claims in respect of the subject matter of the dispute between the parties, it can exercise the right to appeal against a decision that does not meet its interests.

A third party without independent claims on the subject of the dispute also has the opportunity to file an appeal. This is due to the fact that although

\footnotetext{
${ }^{3}$ Civil process of Ukraine: academic course: Ptruck. for students. Yuri. spets. no. Uch. zakl.; for zag. ed. Kyiv: publisher Fursa S.: KNT, 2009. 848 p.
} 
the court decision only indirectly affects its rights, freedoms or interests, but in the future, this decision may affect the legal relationship of a third party with one of the parties, as well as entail undesirable legal consequences for this person (for example, the presentation of a recourse claim).

A judicial representative (lawyer, legal adviser, etc.) may appeal a court decision on appeal only if the person whose interests he represents has not limited him in this power. Limits of authority to commit certain procedural actions (including on appeal) should be specified in the power of attorney.

Legal representatives (parents, adoptive parents, guardians or other persons defined by law) may perform all procedural actions on behalf of the persons they represent, including appeals against the decision. This means that the legal representative, in contrast to the contractual representative, at its discretion decides on the need to appeal to the court of appeal in order to protect the rights and legitimate interests of the person he represents ${ }^{4}$.

Bodies and persons who are granted the right to protect the rights, freedoms and interests of other persons by law (article 45 of the civil procedure code of Ukraine) also have the opportunity to appeal the decision, but on condition that they participated in the consideration of the case by the court of first instance. This restriction does not apply to the Prosecutor.

Unlike other persons listed in Art. 45 of the civil procedure code of Ukraine, the Prosecutor, even if he did not participate in the case, can appeal the decision of the court of first instance on appeal.

The subjects of appeal are also applicants and interested persons in cases of special proceedings, collectors and debtors in cases of writ proceedings.

Special attention should be paid to the implementation of the right to appeal by persons who did not participate in the case, but the court decided on their rights and obligations. In item 1 of the resolution of Plenum of the Supreme Court of Ukraine No. 12 of October 24, 2008 "About judicial practice of consideration of civil cases in the appeal order" it is explained that in connection with possibility of the appeal of a judgment by the specified persons, they according to part 9 of art. 6 code of civil procedure are entitled to the court which made the decision, verbal or written information about the outcome of the case, to get acquainted with case materials, make extracts, make copies of documents attached to the case, receive copies of decisions and determinations, and the proceedings in the appellate court acquires rights of persons involved in the case, in particular, to participate in the proceedings, to submit petitions, get acquainted with the case materials, submit evidence, and the like.

\footnotetext{
${ }^{4}$ Belousov Y., Ugrinovska O. civil process: Uch. POS. Kiev: Precedent, 2005.
} 
The appeal is filed after the expiration of the term of appeal, if the person who filed it does not violate the question of the restoration of this term, or if the grounds for the renewal of the term specified in the application are found to be disrespectful, remains motionless. On leaving the appeal without motion, the court makes a determination. Thus within thirty days from the moment of receipt of such decision the person has the right to address in appellate court with the statement on restoration of term or to specify other bases for renewal of term (in case of recognition by appellate court of the reasons of the pass of term specified in the statement submitted earlier, disrespectful).

The court of appeal can restore the term of appeal if it was missed for good reasons (business trip, illness, etc.). The decision on this issue is made by the court of appeal on the basis of the application submitted by the interested person and the necessary evidence. The legislation does not clearly define what reasons can be recognized as valid, so the court assesses them as relative to each specific situation ${ }^{5}$.

Restoration of the term of appeal taking into account the requirements of article 73 of the civil procedure code of Ukraine.

In case of failure of the person of the statement in the term specified above or the bases specified by it for renewal of term of the appeal disrespectful, the appellate court refuses opening of appeal proceedings.

Regardless of the validity of the reason for missing the term of appeal, the court of appeal refuses to open appeal proceedings if the appeal of the Prosecutor, public authority or local self-government body is filed after the expiration of one year from the date of announcement of the appealed court decision (part 3 of article 297 of the civil procedure code of Ukraine).

Civil procedural legislation regulates in detail the requirements for the form and content of the appeal. According to article 295 of the code of civil procedure of Ukraine the appeal is filed in writing.

In the appeal complaint shall be specified:

1) the name of the court to which the complaint is filed;

2) the name (name) of the person filing the complaint, his / her place of residence or location;

3) the name (name) of the persons participating in the case, their place of residence or location;

4) the decision or decision to be appealed;

5) the illegality and (or) the invalidity of the decision or resolution (incompleteness of establishment of circumstances relevant to the case, and

${ }^{5}$ Stefan O. Claim proceedings in cases of copyright and related legal relations in civil proceedings of Ukraine. Kiev, 2003. 236 p. 
(or) the fallacy of establishing the circumstances relevant to the case, due to unjustified refusal to accept evidence, improper investigation or evaluation, failure to submit evidence for valid reasons and (or) incorrect definition according to the established court circumstances of legal relationship);

6) new circumstances to be established, evidence to be investigated or evaluated, justification of the validity of the reasons for the failure to submit evidence to the court of first instance, objections to the evidence used by the court of first instance;

7) petition of the person who filed the complaint;

8) list of documents and other attached materials.

The appeal is signed by the person who submits it, or a representative of such person.

The power of attorney or other document certifying powers of the representative if these documents were not submitted earlier shall be attached to the appeal filed by the representative.

The appeal shall be accompanied by copies of the complaint and the attached written materials according to the number of persons involved in the case.

In addition, the appeal must be accompanied by a receipt for payment of the court fee for filing a complaint. The law of Ukraine "About court fee" is determined by that of the appeal court's decision, statement on joining the appeal to the court will be charged 50 percent of the rate payable when submitting the claim, other claims, and in the case of filing a claim of material nature -50 percent of the rate calculated on the basis of the disputed amount. That is, in this case, the court fee is equal to half the amount of the court fee paid when applying to the court of first instance.

According to the rules of part 1 of article 296 of the civil procedure code of Ukraine, an appeal is filed to the court of appeal through the court of first instance, which adopted the appealed judgment.

The court of first instance shall send the appeal together with the case to the court of appeal the next day after the deadline for filing the appeal. Appeals received after that, not later than the next working day after their receipt are sent to the court of appeal.

\section{Opening of appeal proceedings in the case}

At the stage of opening the appeal proceedings in the case, the possibility of accepting the appeal for consideration in the court of appeal is determined.

Within this stage, the judge of the court of appeal (Judge-Rapporteur) carries out a number of procedural actions provided for in article 297 of the civil procedure code of Ukraine. Thus, the case is registered in the court of 
appeal in the manner prescribed by parts 2 and 3 of article 11-1 of the CPC, and not later than the next day is transferred to the Judge-Rapporteur. Within three days after the receipt of the case, the Judge-Rapporteur decides on the opening of appeal proceedings ${ }^{6}$.

To the appeal which is not issued according to the requirements established by Art. $295 \mathrm{CPC}$, and also in case of non-payment of the sum of judicial collecting provisions of Art. $121 \mathrm{CPC}$ apply (the appeal remains without movement).

In addition, the court of appeal may leave the complaint without motion on the grounds specified in part 3 of article 297 of the CPC (in case of missing the deadline for its submission or recognition of the reasons for missing such a deadline as disrespectful), or, if there are conditions provided for by this norm, refuse to open proceedings, as mentioned earlier.

Also, the Judge-Rapporteur refuses to open appeal proceedings in cases where:

1) the case is not subject to appeal in civil proceedings;

2) there is a decision to close the appeal proceedings in connection with the refusal of the person from the appeal;

3) there is a decision to refuse to satisfy the appeal of this person or to refuse to open appeal proceedings on the appeal.

On the opening or refusal to open the appeal proceedings in the case, leaving the appeal without motion or return of the complaint, the JudgeRapporteur shall make a determination. A copy of the ruling on the return of the appeal or refusal to open the appeal proceedings, together with the materials attached to the complaint, is sent to the person who filed the appeal, and the appeal remains in the case. To other persons participating in business, the copy of the corresponding resolution goes.

The decision on the return of the appeal, the refusal to open appeal proceedings in the case may be appealed in cassation.

Upon receipt of improperly decorated case, with the outstanding comments on the correctness and completeness of fixing trial by technical means or with outstanding written observations regarding the completeness or incorrectness of the journal of the hearing, or without addressing the question of the adoption of an additional decision judge returns the case to the court of first instance, decides what the definition indicating the period during which the court of first instance should address the shortcomings.

The court of appeal not later than the next day after the ruling on the opening of appeal proceedings in the case sends copies of the appeal and

\footnotetext{
${ }^{6}$ Kroitor V. Civil process: Textbook for preparation for the test and exam. Ed. 3rd, pererab. I DOP. Kharkiv: Espada, 2006.
} 
attached materials to persons who take part in the case, and sets the period within which objections to the appeal may be filed (article 298 of the civil procedure code of Ukraine) ${ }^{7}$.

If the complaint is accepted by the court of appeal for consideration, interested persons have the opportunity to join this appeal (article 299 of the civil procedure code of Ukraine), which drew attention to above.

The person who filed the appeal has the right to Supplement, change or withdraw it or refuse the appeal in compliance with the procedure established by Art. 300 of the civil procedure code of Ukraine.

\section{Preparation of the case for consideration in the court of appeal. Appointment of the case to the court of appeal}

The purpose of this stage of appeal proceedings (preparation of the case) is to implement a system of procedural actions that will ensure in the future timely, comprehensive (within the arguments of the appeal and the requirements stated in the court of first instance) and objective consideration of the case by the court of appeal.

Within ten days from the date of receipt of the case, the JudgeRapporteur performs the following preparatory actions:

1) clarify the question of the composition of the persons involved in the case;

2) determines the nature of the disputed legal relations and the law that regulates them;

3) clarify the circumstances referred to by the parties and other persons involved in the case as the basis of their claims and objections;

4) find out what circumstances are recognized or denied by the parties and other persons;

5) decides on the validity of the reasons for failure to submit evidence to the court of first instance;

6) at the request of the parties and other persons involved in the case, decides on the call of witnesses, appointment of expertise, reclamation of evidence, court orders to collect evidence, involvement in the case of a specialist, an interpreter;

7) at the request of persons participating in the case, decides on the adoption of measures to ensure the claim;

8) performs other actions related to ensuring the appellate consideration of the case (article 301 of the civil procedure code of Ukraine).

\footnotetext{
${ }^{7}$ Course of civil procedure: Textbook / V. Komarov, V. Bigun, V. Barankova et al.; ed. Kharkiv: Pravo, 2011. 1352 p.
} 
After carrying out preparatory actions, the Judge-Rapporteur reports on them to the panel of judges, which, if necessary, decides on the conduct of additional preparatory actions and the appointment of the case for consideration.

The case must be appointed for consideration within a reasonable time, but not later than seven days after the end of preparation for consideration (article 302 of the civil procedure code of Ukraine) ${ }^{8}$.

\section{The procedure for consideration of the case by the court of appeal. Consequences of non-appearance in court session of the persons participating in business. Term of consideration of the appeal}

Consideration of the case in the court of appeal is the most important stage of the appeal proceedings, as it directly deals with the essence of the issues outlined by the interested person in the filed appeal.

Cases in the court of appeal are considered according to the rules established for consideration in the court of first instance, but with exceptions and additions provided for by Chapter 1 of section $\mathrm{V}$ of the CPC (article 304 of the CPC of Ukraine).

The appeal to the court of first instance considered in open court (article 6 of CPC of Ukraine) a panel of three judges, the presiding judge of which is determined in accordance with the law (art. 11-1, 18 code of civil procedure of Ukraine). Closed trial is allowed on the same grounds as in the court of first instance (article 6 of the civil procedure code of Ukraine) ${ }^{9}$.

The session of the court of appeal consists of the following parts:

1) preparatory;

2) consideration of the appeal on the merits;

3) judicial debate;

4) adoption and proclamation of the decision by the court of appeal.

In the preparatory part of the hearing, the court resolves a number of issues: whether a complaint in case of absence in judicial session someone from the participants or of all persons involved in the case; whether the proceedings in this part of the court; clarifies the rights and obligations of persons participating in the case; decides the declared petitions and the like. In case of the statement of petitions for challenges, the court considers them in the order of Art. 20-25 of GPK of Ukraine.

Prineas appeal sumasali involved in the case, a panel of judges in accordance with article 305 of the CCP, with the possibility of proceedings

\footnotetext{
${ }^{8}$ Civil process of Ukraine: academic course: Ptruck. for students. Yuri. spets. no. Uch. zakl.; for zag. ed. Kyiv: publisher Fursa S.: KNT, 2009. 848 p.

${ }^{9}$ Belousov Y., Ugrinovska O. civil process: Uch. POS. Kiev: Precedent, 2005.
} 
in this court. According to part 1 of article 305 of the CCP, the court of appeal adjourns the proceedings in case of absence in judicial session of the person participating in business, concerning which there is no information on the award of her subpoena, or at his request, when informed of the reasons of absence will be recognized by a court as valid.

The failure of the parties or other persons participating in business, properly informed on time and place of the hearing, but absent at the hearing for unknown or valid reasons does not preclude consideration of the case.

Consideration of the appeal on the merits begins with a report of the Judge-Rapporteur, which outlines the content of the appealed decision (ruling) of the court of first instance, the arguments of the appeal, the limits within which must be checked by the decision (order) to establish the circumstances and explore the evidence.

After the report, the presiding judge determines whether the person supports the appeal filed by him or her and whether the parties do not wish to conclude the case with a settlement agreement. Then the explanations of the person who filed the appeal are heard. In the case of an appeal against the decision (determination) of the court by both parties, the plaintiff first gives an explanation. Further explanations are given by other persons involved in the case.

In this part, the court of appeal also clarifies the circumstances of the case and checks them with evidence. According to Art. 303 of the civil procedure code of Ukraine, the court of appeal examines evidence that the court of first instance was investigated in violation of the established procedure or the study of which was wrongfully refused, as well as new evidence, the failure to submit to the court of first instance was due to valid reasons.

After consideration of the appeal on the merits, the court of appeal provides the persons participating in the case, the opportunity to speak in the judicial debate in the same sequence in which they gave explanations. The court may limit the duration of judicial debate, setting for all participants in the process an equal period of time, as announced at the beginning of the court session ${ }^{10}$.

After the end of the debate, the court goes to the deliberative room to make a decision. All issues arising during the discussion and adoption of the decision of the court of appeal shall be resolved by a majority vote. At the decision of each question none of judges has the right to abstain from vote. The Chairman votes last (article 19 of the CPC of Ukraine).

${ }^{10}$ Stefan M. Civil procedural law of Ukraine: Academic course: Textbook. for students. Yuri. spets. no. Uch. zakl. Kiev: Concern "Publishing House "In Jure", 2005. 
The decision adopted by the appellate instance is proclaimed publicly (articles 317, 218 of the civil procedure code of Ukraine).

After the end of the appeal proceedings, the case is sent to the court of first instance, which considered it, within seven days.

The appeal to Rsankarsub Konstantin to be considered within two months from the date of the ruling on acceptance of appeal for consideration, and the appeal of first instance within fifteen days from the date of the ruling on acceptance of appeal for consideration.

In exceptional cases at the request of the party taking into account features of consideration of the case the appellate court can prolong term of consideration of the case, but no more than for fifteen days about what the corresponding definition resolves (Art. 303-1 CPC of Ukraine).

\section{Powers of the court of appeal}

The powers of the court of appeal are enshrined in the CPC of Ukraine, represent the totality of its rights to carry out certain procedural actions regarding the decision (determination) of the court of first instance, which is the subject of verification on appeal.

Having considered the case on appeal against the decision of the court of first instance, the court of appeal has the right:

1) to decide the decision to reject the appeal and leave the decision unchanged;

2) cancel the decision of the court of first instance and take a new decision on the merits of the claims;

3) to change the decision;

4) to decide on the abolition of the decision of the court of first instance and the closure of proceedings or abandonment of the application without consideration (Art. 307 of the CPC of Ukraine).

Abandonment of the decision without changes, that is rejection of the appeal, can take place in that case when this decision is lawful and reasonable, accepted with observance of norms of material and procedural law on the basis of comprehensive research of the proofs collected on business, their correct assessment and the reasoned conclusions. According to article. 308 of the civil procedure code of Ukraine cannot be canceled in fact correct and fair judgment for only formal reasons ${ }^{11}$.

In paragraph 18 of the resolution of Plenum of the Supreme Court of Ukraine № 12 of October 24, 2008 “On judicial practice of consideration of

${ }^{11}$ Civil procedure code of Ukraine: Scientific and practical commentary: In 2 vols. / For zag. ed. K.: publisher Fursa S. Y.: KNT, 2007. 
civil cases on appeal" it is noted that the disadvantages that do not result in the violation of the basic principles of civil procedural law and legally protected rights and interests of persons involved in the case, and do not affect the essence of the decision include the payment of court fees, carried out after the commencement of the case; the lack of the signature in the statement of claim if the plaintiff participated in the hearing and supported claims; absence of the signature of the Secretary of the court session in the journal of the court session; leaving without consideration of the application for recusal, if there were no grounds for recusal. The same drawback can be recognized in itself the lack of technical records with indisputable evidence, which justified the decision.

The grounds for revoking the decision of the court of first instance and making a new decision or changing the decision are:

1) incomplete clarification by court of the circumstances having value for business;

2) lack of evidence of circumstances relevant to the case, which the court considered established;

3) discrepancy of conclusions of court to circumstances of business;

4) violation or incorrect application of norms of substantive or procedural law, as well as consideration and decision of the case by an inferior court; participation in the decision of the judge, who was challenged on the basis of circumstances that raised doubts about the impartiality of the judge, and the application for his challenge was recognized by the court of appeal as justified.

Norms of substantive law are considered violated or improperly applied if a law is applied that does not apply to these legal relations, or the law that was subject to application is not applied.

Violations of procedural law may be grounds for cancellation or change of the decision, if such violations led to improper resolution of the case (article 309 of the civil procedure code of Ukraine).

Cancellation of the court decision on appeal with the termination of proceedings or abandonment of the application without consideration occurs from the grounds provided by articles 205 and 207 of the civil procedure code of Ukraine (article 310 of the civil procedure code).

If the court of first instance made a legitimate and reasoned decision, the death of the natural person or termination of legal entities - parties in contentious relationship after deciding that prevents succession, cannot be the basis for the application of the requirements of part 1 of article 310 of CPC of Ukraine.

According to the results of consideration of the appeal against the court order the court of appeal has the right: 
1) to decide on the rejection of the appeal and leave the court order unchanged. The decision of the court of appeal to dismiss the appeal against the court order and leave the court order unchanged is final and is not subject to appeal;

2) decide the order abolishing a court order and to clarify that the creditor requirements may be considered in action proceeding, subject to the General rules for filing a claim. A court order, which is a special form of a court decision, may be revoked on appeal, if the court of appeal establishes the absence between the claimant and the debtor of certain legal relations, on the basis of which the claim under part 1 of article 96 of the civil procedure code was declared. The decision of the court of appeal on cancellation of the court order is final and is not subject to appeal (Art. 309-1 of the civil procedure code of Ukraine).;

3) change the court order. If a court order is changed, the court of appeal must issue a new court order. At the same time, the previous court order issued by the court of first instance loses its legal force ${ }^{12}$.

By results of consideration of the appeal on determination of court of the first instance the appellate court has the right:

1) to decide the decision to reject the appeal and leave the decision unchanged;

2) cancel the definition and adopt a new definition;

3) change the definition;

4) to cancel the definition preventing further production on business, and to direct business for continuation of consideration in court of the first instance.

Grounds for rejection of the complaint to the determination of the court of first instance or changes or cancellations of the decision specified in article. 312 CPC of Ukraine. So, having considered the complaint on determination of court of the first instance, appellate court:

1) dismisses the complaint and leaves the definition unchanged, if the court of first instance decided the definition in compliance with the requirements of the law;

2) changes or cancels determination of court of the first instance and decides the resolution on this question if it was decided by court of the first instance with violation of norms of procedural law or at the correct decision the essence of procedural action or the bases of its application was mistakenly formulated;

\footnotetext{
${ }^{12}$ Yasinok M., Kroitor V. principles of oral, immediacy and continuity in civil proceedings: monograph. Kharkov.: Espada, 2007. 152 p.
} 
3) cancels the decision and transfers the question for new consideration to the court of the first instance if the last violated the order established for its decision.

Grounds for cancellation of the court ruling preventing further proceedings in the case, and the direction of the case for further consideration in the court of first instance:

1) incomplete clarification by court of the circumstances having value for business;

2) lack of evidence of circumstances relevant to the case, which the court of first instance considers established;

3) discrepancy of conclusions of court to circumstances of business;

4) violation of the norms of substantive or procedural law, which led to the wrong solution of the issue (article 311 of the civil procedure code of Ukraine).

\section{The procedure for making decisions and decisions determinations by the court of appeal}

According to article 313 of the CPC of Ukraine the court of appeal takes a decision and makes decision according to the rules of article 19 and Chapter 7, section III of the code of civil procedure of Ukraine with the exceptions and additions set forth in articles 314 to 316 of the CPC of Ukraine.

The decision (definition) of appellate court is made out by the judge-the Rapporteur and signed by all structure of court which considered business.

In accordance with part 1 of article 314 of the civil procedure code of Ukraine, the court of appeal, having considered the case, makes a determination in cases:

1) rejection of the appeal and leaving the court decision unchanged;

2) cancellation of the definition preventing further production on business, and the direction of business for continuation of consideration in court of the first instance;

3) cancellation of the court decision with the closure of the proceedings or leaving the application without consideration;

4) rejection of the appeal and leaving the court's ruling unchanged;

5) changes in the ruling of the court of first instance;

6) cancellation of definition and the decision of a question on the merits.

In addition, the determination is made in the case of rejection of the appeal against the court order and leaving the court order unchanged, as well as in the case of cancellation of the court order.

The content of the decision of the court of appeal is determined by article 315 of the civil procedure code of Ukraine, in particular it consists of:

1) the introductory part indicating: 
- time and place of its resolution;

- the name of the court;

- names and initials of the presiding officer and judges;

- surnames and initials of the Secretary of court session;

- name of the case and full names (names) of persons participating in the case;

2) descriptive part indicating:

- summary of the requirements of the appeal and the judgment of the court of first instance;

- generalized arguments of the person who filed the appeal;

- generalized arguments and objections of other persons involved in the case;

- the circumstances established by the court of first instance;

3) the motivational part indicating:

- the reasons from which the court of appeal proceeded in the decision of the ruling, and the provisions of the law, which guided it;

4) the operative part indicating:

- conclusion of the court of appeal;

- allocation of court costs;

- the term and procedure for the entry into force of the resolution and its appeal.

When rejecting an appeal, the decision notes the reasons for its rejection.

In case of cancellation of definition of court which prevents further proceedings and sending the case to continue before the court of first instance in the resolution should be stated, what violations of law were committed by the trial court.

Under. 2 Art. 314 CPC the appellate court makes the decision in cases of cancellation of the judgment and acceptance of new or change of the decision.

The content of the decision of the court of appeal is determined by article 316 of the civil procedure code of Ukraine, in particular, it consists of:

1) the introductory part indicating:

- time and place of its adoption;

- the name of the court;

- names and initials of the presiding officer and judges;

- surnames and initials of the Secretary of court session;

- name of the case and full names (names) of persons participating in the case;

3) descriptive part indicating:

- review of the content of claims and decisions of the court of first instance; 
- summary of the requirements of the appeal;

- generalized arguments of the person who filed the appeal; case;

- generalized arguments and objections of other persons involved in the

4) the motivational part indicating:

- reasons for changing the decision, revoking the decision of the court of first instance and making a new decision;

- established by the court of first instance and not contested circumstances, as well as the circumstances established by the court of appeal, and defined in accordance with them legal relations;

- were and by whom violated, unrecognized or challenged the rights, freedoms or interests, for the protection of which the person appealed to the court;

- title, article, its part, paragraph, paragraph, sub-paragraph of the law on the basis of which the case was decided, as well as procedural law, which guided the court;

5) the operative part indicating:

- decision of the court of appeal to change or cancel the decision, satisfaction of the claim or refusal of the claim in whole or in part;

- conclusions of the court of appeal on the merits of claims;

- allocation of court costs;

- the term and procedure for the entry into force of the decision and its appeal.

Decisions and decisions of the court of appeal are proclaimed according to the rules established by Art. 218 of the civil procedure code of Ukraine.

The decision or determination of the court of appeal shall enter into force from the moment of their proclamation (article 319 of the civil procedure code of Ukraine).

Court decisions (decisions) of the court of appeal are issued, issued or sent in the manner prescribed by Art. 222 of the civil procedure code of Ukraine.

Copies of court decisions (rulings) of the court of appeal are re-issued by the court of first instance, where the case is stored (article 321 of the civil procedure code of Ukraine).

\section{Appeal against the decisions of the court of first instance}

According to article 293 of the civil procedure code of Ukraine separately from the decision of the court can be appealed in the appellate order of the court of first instance:

1) refusal to accept an application for the issuance of a court order or the cancellation of a court order; 
2) security of the claim, and also about cancellation of security of the claim;

3) return of the application to the plaintiff (applicant);

4) refusal to open proceedings;

5) commencement of proceedings in the case of non-compliance with the rules of jurisdiction;

6) transfer of the case to another court;

7) refusal to restore or extend the missed procedural term;

8) recognition of the settlement agreement at the request of the parties;

9) determination of court costs;

10) correction of the decision;

11)refusals to make an additional decision;

12)explanation of the decision;

13) suspension of proceedings;

14) closure of the proceedings;

15) abandonment of the application without consideration;

16) abandonment of the application for revision of the absentee decision without consideration;

17)refusal to open proceedings on newly discovered circumstances;

18)issuance of a duplicate of the writ of execution;

19)restoration of the missed term for presentation of the Executive document for execution;

20)deferrals and installments, changes or establishment of the method and order of execution of the decision;

21)temporary placement of the child in a children's or medical institution;

22) announcements of search of the Respondent (debtor) or the child;

23)forced entry into housing;

24) the levy of execution on funds held in the accounts;

24-1) temporary restrictions on the right to travel outside Ukraine;

25)replacement of the party of enforcement proceedings;

26) determination of the share of the debtor's property in the property that he owns jointly with other persons;

27)decisions, actions or inaction of the state Executive or other official of the State Executive service;

28)turning the execution of the judgment;

28-1) correction of an error in the Executive letter or recognition of the writ of execution not subject to execution;

29)denial of renewal of the lost judicial proceedings;

30) dismissal (appointment) of a guardian or Trustee; 
31)refusal to open proceedings in the case of cancellation of the decision of the arbitration court;

32)return of the application for cancellation of the decision of the arbitration court;

33)return of the application for issuance of the writ of execution for enforcement of the arbitration court decision.

In the case of an appeal to the court of first instance, paragraphs 2, 7, 9, 18-30 part 1 of article 293 of civil procedure, the court of appeals transmitted a copy of materials necessary for consideration of the complaint. If necessary, the court of appeal may also request copies of other case materials.

During consideration of the complaint on determination of court of the first instance the appellate court shall comprehensively and completely check legality of the made decision on the basis of the case materials provided to it.

Filing an appeal against the decision of the court of first instance does not prevent the continuation of the case by this court.

Decisions of the appellate instance, made on the basis of consideration of appeals against the decisions of the courts of first instance, shall enter into force immediately after their proclamation.

Objections to rulings that are not subject to appeal separately from the court's decision are included in the appeal against the court's decision "(see: "Form and content of the appeal"). In case of filing an appeal against a ruling that is not subject to appeal separately from the court's decision, the court of first instance returns it to the applicant, as decided by the ruling that is not subject to appeal.

\section{CONCLUSIONS}

The essence and significance of the appeal proceedings. Right of appeal. Terms of appeal. Form and content of the appeal. The procedure for filing an appeal. The procedure for accepting an appeal for consideration. Preparation of the case by the court of appeal. Appointment of the case to the court of appeal. The procedure for consideration of the case by the court of appeal. Powers of the court of appeal. The order of decision-making and decisionmaking by the court of appeal. Appeal against decisions of the court of first instance.

\section{SUMMARY}

Appeal proceedings are the stage of the criminal process in which the higher court hears on appeals against judicial decisions of the courts of first instance, which have not entered into force, and can eliminate the 
shortcomings and judicial errors made during the consideration of the lower court. The law provides for a wide range of subjects of criminal proceedings who have the right to appeal against a court decision of the court of first instance on appeal. The law establishes mandatory requirements for an appeal. An essential novelty of the appeal proceedings is the possibility of the court of appeal to accept a criminal case for its production, to consider it on the merits and decide its verdict.

\section{REFERENCES}

1. Course of civil procedure: Textbook / V. Komarov, V. Bigun, V. Barankova et al.; ed. Kharkiv: Pravo, 2011. 1352 p.

2. Civil process of Ukraine: academic course: Ptruck. for students. Yuri. spets. no. Uch. zakl.; for zag. ed. Kyiv: publisher Fursa S.: KNT, 2009. 848 p.

3. Kroitor V. Civil process: Textbook for preparation for the test and exam. Ed. 3rd, pererab. I DOP. Kharkiv: Espada, 2006.

4. Civil process: the textbook. allowance / per zag. ed. NATs. UN-t EXT. cases'. Kharkiv: Vid-vo Hark. NATs. UN-t EXT. del, 2009. 266 p.

5. Civil process: the Textbook. no. / A.Andrushko, Y. Belousov, R. Stefanchuk, O. Ugrinovskaya, et al. Kiev: Precedent, 2005.

6. Civil process of Ukraine: Problems and prospects: Scientific and practical manual. K.: publisher Fursa S. Ya.: KNT, 2007.

7. Civil procedure code of Ukraine: Scientific and practical commentary: In 2 vols. / For zag. ed. K.: publisher Fursa S. Y.: KNT, 2007.

8. Belousov Y., Ugrinovska O. civil process: Uch. POS. Kiev: Precedent, 2005.

9. Stefan M. Civil procedural law of Ukraine: Academic course: Textbook. for students. Yuri. spets. no. Uch. zakl. Kiev: Concern "Publishing House "In Jure", 2005.

10. Stefan O. Claim proceedings in cases of copyright and related legal relations in civil proceedings of Ukraine. Kiev, 2003. 236 p.

11. Yasinok M., Kroitor V. principles of oral, immediacy and continuity in civil proceedings: monograph. Kharkov.: Espada, 2007. 152 p.

\section{Information about the author: Voronin Ya. G.,} Doctor of Law, Professor, Professor at the Department of Administrative, Criminal Law and Procedure, International University of Business and Law 37-A, 49 HGD str., Kherson, 73040, Ukraine 
Publishing house "Liha-Pres"

9 Kastelivka str., Lviv, 79012, Ukraine 44 Lubicka str., Torun, 87-100, Poland

Printed by the publishing house "Liha-Pres"

Passed for printing: August 28, 2019.

A run of 150 copies. 